US Army Corps

of Engineers .

Prepared for the U.S. Army Corps of Engineers, Portland District,

under an Interagency Agreement with the U.S. Department of Energy

Contract DE-AC05-76RL01830

\title{
A Synthesis of Environmental and Plant Community Data for Tidal Wetland Restoration Planning in the Lower Columbia River and Estuary
}

FINAL REPORT

HL Diefenderfer

AB Borde

VI Cullinan

December 2013

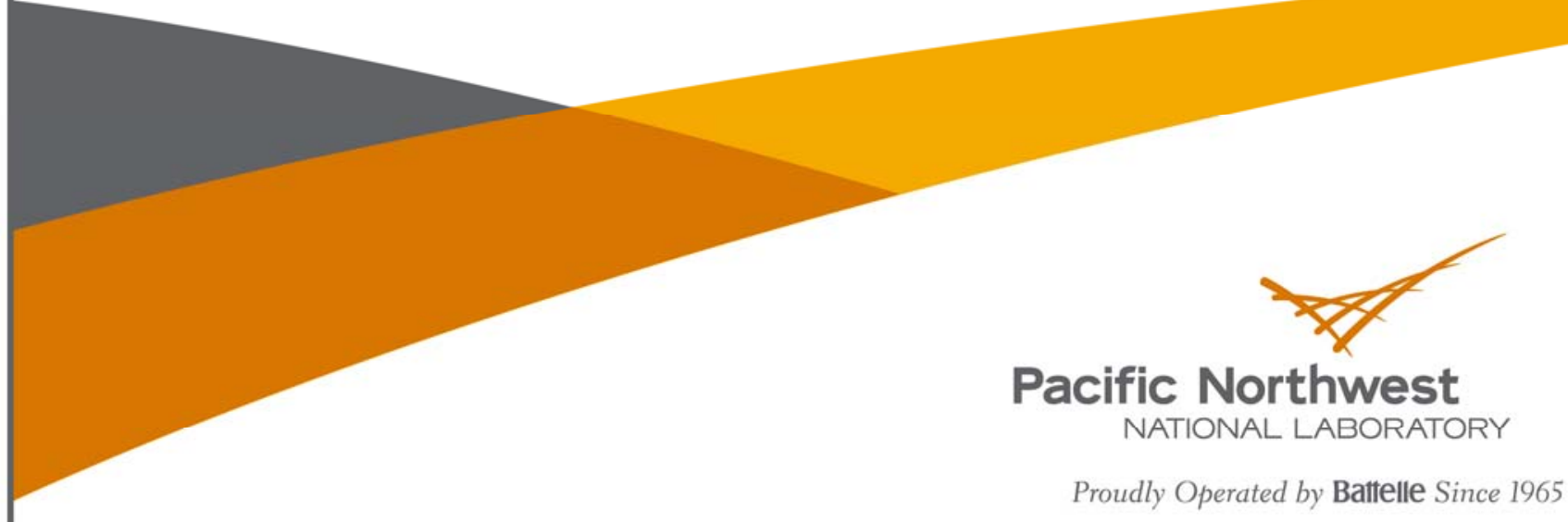




\title{
DISCLAIMER
}

This report was prepared as an account of work sponsored by an agency of the United States Government. Neither the United States Government nor any agency thereof, nor Battelle Memorial Institute, nor any of their employees, makes any warranty, express or implied, or assumes any legal liability or responsibility for the accuracy, completeness, or usefulness of any information, apparatus, product, or process disclosed, or represents that its use would not infringe privately owned rights. Reference herein to any specific commercial product, process, or service by trade name, trademark, manufacturer, or otherwise does not necessarily constitute or imply its endorsement, recommendation, or favoring by the United States Government or any agency thereof, or Battelle Memorial Institute. The views and opinions of authors expressed herein do not necessarily state or reflect those of the United States Government or any agency thereof.

\author{
PACIFIC NORTHWEST NATIONAL LABORATORY \\ operated by \\ BATTELLE \\ for the \\ UNITED STATES DEPARTMENT OF ENERGY \\ under Contract DE-AC05-76RL01830
}

Printed in the United States of America
Available to DOE and DOE contractors from the Office of Scientific and Technical Information,
P.O. Box 62, Oak Ridge, TN 37831-0062;
ph: (865) 576-8401
fax: $(865)$ 576-5728
email: reports@adonis.osti.gov
Available to the public from the National Technical Information Service
5301 Shawnee Rd., Alexandria, VA 22312
ph: (800) 553-NTIS (6847)
email: orders@ntis.gov <http://www.ntis.gov/about/form.aspx>
Online ordering: http://www.ntis.gov

This document was printed on recycled paper. 


\section{A Synthesis of Environmental and Plant Community Data for Tidal Wetland Restoration Planning in the Lower Columbia River and Estuary}

\section{FINAL REPORT}

HL Diefenderfer

AB Borde

VI Cullinan

December 2013

Prepared for

U.S. Army Corps of Engineers, Portland District

under an Interagency Agreement with the U.S. Department of Energy

Contract DE-AC05-76RL01830

Pacific Northwest National Laboratory

Marine Sciences Laboratory

Sequim, Washington 99382 



\section{Preface}

This research was performed under the auspices of the U.S. Army Corps of Engineers (USACE), Congressionally-authorized Columbia River Fish Mitigation Project, and coordinated regionally through the Anadromous Fish Evaluation Program. The study code is EST-P-09-1 and the study title is Evaluation of Life History Diversity, Habitat Connectivity, and Survival Benefits Associated with Habitat Restoration Actions in the Lower Columbia River and Estuary. The study was funded by the USACE Portland District (CENWP) (Ref. No. W66QKZ10249512) under an agreement with the U.S. Department of Energy for work by Pacific Northwest National Laboratory (PNNL). Ms. Cynthia Studebaker was the CENWP's technical lead for the study.

The purpose of this report is to support improvements in tidal wetland restoration and creation project designs in the lower Columbia River and estuary by providing information regarding plant community requirements. This report consists of two, unpublished technical memoranda that were delivered to USACE for review in 2012:

- Diefenderfer, HL, AB Borde, and VI Cullinan. Environmental Information for Tidal Wetland Ecosystem Restoration Planning in the Lower Columbia River and Estuary Region: Memorandum 1, Plant Species Distribution and Physical Environment. April 27, 2012.

- Diefenderfer, HL, AB Borde, and VI Cullinan. Environmental Information for Tidal Wetland Ecosystem Restoration Planning in the Lower Columbia River and Estuary Region: Memorandum 2, Disturbance History and Ecology of Reference Wetlands. July 16, 2012.

Report Citation:

Diefenderfer, H.L., A.B. Borde, and V.I. Cullinan. 2013. A Synthesis of Environmental and Plant Community Data for Tidal Wetland Restoration Planning in the Lower Columbia River and Estuary. PNNL-22667, prepared by the Pacific Northwest National Laboratory, Marine Sciences Laboratory, Sequim, Washington, for the U.S. Army Corps of Engineers, Portland District, Portland, Oregon. 



\section{Executive Summary}

This report reanalyzes and synthesizes previously existing environmental and plant community data collected by PNNL at 55 tidal wetlands and 3 newly restored sites in the lower Columbia River and estuary (LCRE) between 2005 and 2011. Whereas data were originally collected for various research or monitoring objectives of five studies, the intent of this report is to provide only information that will have direct utility in planning tidal wetland restoration projects. Therefore, for this report, all tidal wetland data on plants and the physical environment, which were originally developed and reported by separate studies, were tabulated and reanalyzed as a whole. The geographic scope of the data collected in this report is from Bonneville Lock and Dam to the mouth of the Columbia River, including tidally influenced low-elevation parts of tributary river floodplains (such as the Grays River in Washington), but not including the Willamette River in Oregon. The intent of this report is to provide environmental and plant community data in tabular form and selected statistical analyses to directly support ecosystem restoration planners. The goals of this report are twofold:

1. to characterize the environmental conditions required to restore and create tidal wetland plant communities in the LCRE similar to the least disturbed wetlands in the region, through synthesis of existing data on ecosystem structures, processes, and functions at reference wetlands;

2. to provide a basis for projecting successional trends at restored and created sites, through the synthesis, analysis, and comparison of existing data on ecosystem structures and processes at tidal wetlands in the LCRE using re-constructed histories of anthropogenic and natural disturbances.

The study sites incorporated in the analyses in this report can be described by a variety of attributes. First, the data are from 55 reference sites including 43 main-stem emergent marshes (including low and high marshes), 4 tributary emergent marshes, 2 shrub-dominated wetlands, 3 main-stem swamps (evergreen forested wetlands), 1 tributary swamp, and 2 deciduous forested wetlands located in riparian areas. Additionally, three recently reconnected sites, including 2 main-stem emergent marshes and 1 tributary emergent marsh, are included in analyses in Section 3 of this report. Five preliminary emergent marsh zones, which were developed by the Lower Columbia Estuary Partnership's Reference Site study through analysis of hydrodynamic regime and vegetation, are used as analytical categories to distinguish environmental data in this report. For the purpose of analyses in Section 3 of this report, we developed new categories of land use history centered on the geographic scale and types of disturbance processes that each site has experienced.

The primary value of this report is in the compilation of data that are important for successful restoration planning in the LCRE region. The report contains extensive tables intended to serve the restoration planner working on a specific site by providing geographically-referenced information including the following factors:

\section{Physical Environment}

- average slope in vegetated wetlands

- range of the growing season sum exceedance value (SEV) by wetland type

- descriptive statistics of sediment accretion rate (centimeters/year) by wetland type, location within sites; and by zone for main-stem river emergent marshes 
- median 7-day average of the daily maximum (7-DADMAX) water temperature (degrees Celsius $\left[{ }^{\circ} \mathrm{C}\right]$ ) in five zones of the main-stem river and in tributaries to the estuary

- channel morphology at the mouth and inundation frequencies from emergent marsh, shrub, and forested sites located in the LCRE floodplain

- descriptions of disturbance history categories

- floodplain and channel sediment and channel morphological characteristics of main-stem river and tributary marshes by disturbance category, wetland type, location within site, and ranked distance from the main channel of the Columbia River.

\section{Plant Communities}

- the average site elevation of herbaceous cover, shrub, and tree cover by wetland type

- herbaceous species found in emergent marshes along the main stem and tributaries of the river and the elevation ranges (meters, Columbia River Datum [CRD]) and locations along the LCRE where they were observed

- herbaceous and shrub species found in shrub wetlands along the main stem of the river, and the elevation ranges and locations along the LCRE where they were observed

- herbaceous, shrub, and tree species found in deciduous and evergreen forested wetlands (swamps) along the main stem and tributaries of the river and the elevation ranges and locations along the LCRE where they were observed

- plant species that are among the most abundant plants, the most frequent plants, and the minor plants of the LCRE

- summary of sites with an average site elevation below $1.5 \mathrm{~m}$, CRD relative to the average cover of reed canarygrass

- plant community characteristics and significance of the differences between disturbance categories for marshes.

In addition to the data tables, some exploratory statistical analyses are also provided to estimate the likelihood of selected wetland plant species occurrence by wetland type associated with a range of structural, process, and functional characteristics, including hydrologic regime, slope and elevation, accretion/erosion rates, salinity influence, and water temperature. In most cases, however, these results are limited by the sample sizes available to represent unique conditions, such as tributary position and salinity, which vary across the study region. Two factors in particular limit the analysis of environmental factors associated with level of disturbance in Section 3 of this report. First, the lack of a complete data set for site establishment year, or site age. Second, the lack of completely defined disturbance histories for each site, particularly in cases where multiple disturbances have occurred (e.g., pile-dike and dredged material placement). Site establishment age is further complicated in some cases at created sites if dredged material was deposited in multiple years. 
The preliminary findings of statistical analyses and land-cover analysis include the following:

\section{Physical Environment}

- The average emergent marsh site elevation in seters North American Vertical Datum of 1988 (NAVD88) significantly increases with river kilometer.

- The width-to-depth ratio of the primary wetland channel at its mouth was significantly different between wetland types.

- The SEV, a hydrologic regime indicator, increases significantly with increasing river kilometer and decreases significantly with average wetland elevation.

- Only 3 of 43 marsh reference sites previously sampled through the above-mentioned studies in the LCRE were present in 1870.

\section{Plant Communities}

- Study sites categorized as marshes that had never been diked were discriminated with $100 \%$ correct classification into five hypothesized emergent marsh (EM) zones based on the abundance of major herbaceous plants and their associated SEVs. These five zones, the delineation of tributary versus main-stem regions, and general wetland cover type (marsh, swamp, shrub) allowed us to characterize and differentiate between major influences on the longitudinal and vertical distribution of wetland plants.

- The number of sites with reed canarygrass cover $>20 \%$ was significantly greater between elevation of 1.5 to 3 than below 1.5 and above $3 \mathrm{~m}$, CRD, however, sampling intensity was lower above $3 \mathrm{~m}$, CRD.

- The average non-native cover increased significantly $(\mathrm{p}<0.001)$ until river kilometer $(\mathrm{rkm}) 60$; further landward it remained consistent.

- The number of sites with reed canarygrass cover $>20 \%$ is significantly fewer in EM1 and significantly greater in EM5.

- Low marshes with broad flat morphologies are not likely to be dominated by reed canarygrass.

- Swamps had significantly smaller SEVs than emergent marshes (Kruskal-Wallis: $n=43 ; \mathrm{p}=0.001$ ).

Based on knowledge gathered over several years of data collection and continually increasing understanding of the limitations of some types of data, we would recommend that scientists consider the following factors when planning future data collection and analyses: 1) tributary wetland elevations should not be surveyed relative to CRD; 2) if main-stem marshes are surveyed using the CRD, their elevations cannot be directly compared to elevations surveyed in tributary marshes using NAVD88; 3) marshes subject to strong tidal influences may be constrained in their lower elevation limits because of desiccation during low tides; 4) the plant communities at sites low in the LCRE affected by higher salinity cannot be directly compared to tidal freshwater sites in the remainder of the study area; and 5) while many marshes are sampled for vegetation in a single year, those with multiple survey years may also be averaged to obtain community characteristics depending on the analytical question.

Finally, the results of both Section 2 and Section 3, reporting our synthesis, analysis, and comparison of existing data on ecosystem structures and processes at tidal wetlands in the LCRE, point to similar 
controlling factors including hydrology, geology, morphology, and elevation at specific restoration sites. Tabular information about key physical and hydrologic metrics is presented to help planners estimate environmental conditions in the regions and wetland types they are working in. These factors may overwhelmingly guide the trajectory of development of sites, and therefore, these factors bear further investigation relative to the ecological data, to support restoration planning.

To the best of our knowledge, this is the first time that information about the distribution of individual plant species in terms of river extent and elevation has been elaborated this specifically for the LCRE region (Table 2.5-2.10). These tables identify the most abundant herbaceous, shrub, and tree species in the region, by EM zone and wetland type, and can be used as a guide to the longitudinal and vertical distribution at which plant species are likely to survive in the region. The tables provide additional information important to planning, including whether the plant species is native or not, invasive/weedy or not, and its wetland status (e.g., facultative, obligate). We also present visual plots of the elevation minimum and maximum at which the most frequently present herbaceous plant species occur by river kilometer, for marshes and all other wetland types. The most frequently occurring plants are identified in tables, as are the average site elevations of herbs, shrubs, and trees. We believe that this information about plant species distribution has the potential to fundamentally inform future restoration planning in the LCRE region. 


\section{Acknowledgments}

The data synthesized herein were primarily collected and reported under five research and monitoring studies: the Lower Columbia River Estuary Partnership ${ }^{1}$ Ecosystem Monitoring Program and Reference Sites studies, funded by the Bonneville Power Administration; and the Corps of Engineers' Cumulative Effects (EST-02-P-04), Multi-Scale Research (EST-P-11-01) (formerly BPA Tidal Freshwater Monitoring [BPA 2005-001-00]), and Salmon Benefits (EST-P-09-1) studies. Dr. Ronald M. Thom provided expert guidance on wetland data collection sampling design and methods to the project teams that collected the data analyzed herein. Cynthia Wright, Ron Kaufmann and Shon Zimmerman contributed to data collection, quality control, and analysis. In addition, we thank Susan Ennor and Mike Parker for editing and formatting the report.

\footnotetext{
${ }^{1}$ Now called the Lower Columbia Estuary Partnership.
} 



\section{Acronyms and Abbreviations}

\begin{tabular}{|c|c|}
\hline${ }^{\circ} \mathrm{C}$ & degree(s) Celsius \\
\hline $\mathrm{cm}$ & centimeter(s) \\
\hline ANOVA & analysis of variance \\
\hline USACE & U.S. Army Corps of Engineers \\
\hline BIM & Burke Island marsh \\
\hline CALY & Carex lyngbyei \\
\hline CAOB & Carex obnupta \\
\hline $\mathrm{CI}$ & confidence interval (or Crims Island) \\
\hline $\mathrm{CIC}$ & Chatham Island created \\
\hline CL & confidence limit \\
\hline CLM & Cunningham Lake marsh \\
\hline CRD & Columbia River Datum \\
\hline $\mathrm{CSl}$ & Campbell Slough 1 \\
\hline 7-DADMAX & 7-day average of the daily maximum (temperature) \\
\hline d.f. & degrees of freedom \\
\hline DIB & Dibblee Slough breach \\
\hline $\mathrm{DIC}$ & Deer Island created \\
\hline ELPA & Eleocharis palustris \\
\hline EM & emergent marsh \\
\hline EP & Lower Columbia Estuary Partnership \\
\hline FLM & Franz Lake marsh \\
\hline GIC & Goat Island created \\
\hline GIM & Grant Island marsh \\
\hline GIS & geographic information system \\
\hline GUC & Gull Island created \\
\hline $\mathrm{HC}$ & Hardy Creek \\
\hline $\mathrm{HCM}$ & Hardy Creek marsh \\
\hline IMSP & species in the genus Impatiens \\
\hline $\mathrm{km}$ & kilometer(s) \\
\hline LCRE & lower Columbia River and estuary \\
\hline LI2 & Lord Island 2 \\
\hline $\mathrm{m}$ & meter(s) \\
\hline$m^{2}$ & square meter(s) \\
\hline MIC & McGuire Island created \\
\hline MIM & Martin Island marsh \\
\hline MLLW & mean lower low water \\
\hline
\end{tabular}




$\begin{array}{ll}\text { MYSP } & \text { species in the genus Myosotis } \\ \text { NAVD88 } & \text { North American Vertical Datum of 1988 } \\ \text { nMDS } & \text { non-metric multi-dimensional scaling } \\ \text { PHAR } & \text { Phalaris arundinacea } \\ \text { PNNL } & \text { Pacific Northwest National Laboratory } \\ \text { OSM } & \text { old Sandy River mouth } \\ \text { OSR } & \text { old Sandy River channel marsh } \\ \text { PIM } & \text { Pierce Island marsh } \\ \text { RIC } & \text { Reed Island created } \\ \text { RIM } & \text { Ryan Island marsh } \\ \text { rkm } & \text { river kilometer(s) } \\ \text { SALA } & \text { Sagittaria latifolia } \\ \text { SEV } & \text { sum exceedance value } \\ \text { SI2 } & \text { Sandy Island 2 } \\ \text { SIM } & \text { Sand Island marsh } \\ \text { TOC } & \text { total organic carbon } \\ \text { WHC } & \text { Whites Island created } \\ \text { WRM } & \text { Washougal River } \\ \text { yr } & \text { year(s) }\end{array}$




\section{Contents}

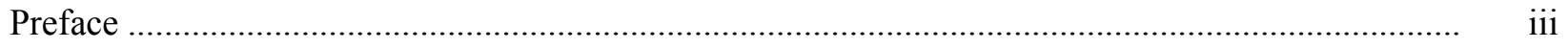

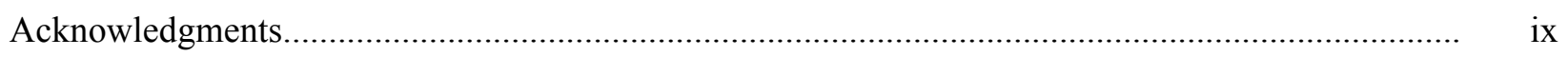

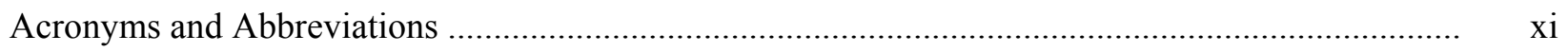

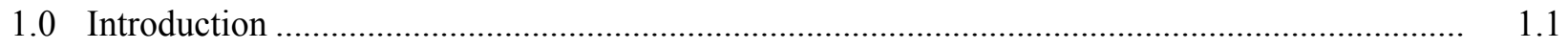

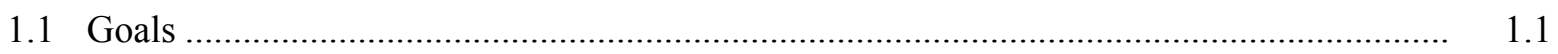

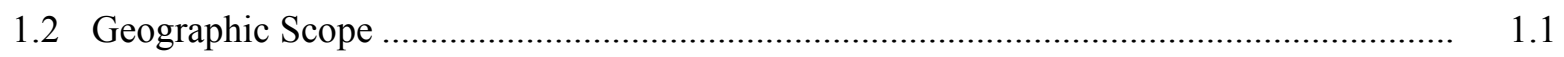

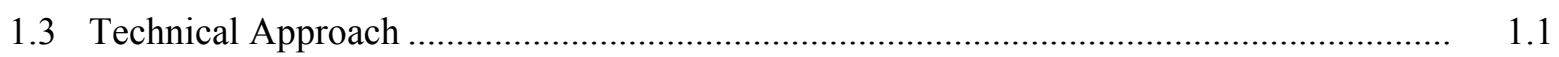

1.3.1 Zonation or Wetland Position.................................................................... 1.1

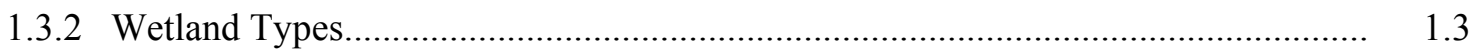

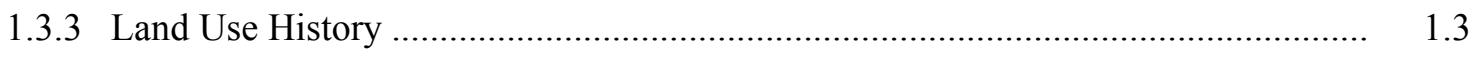

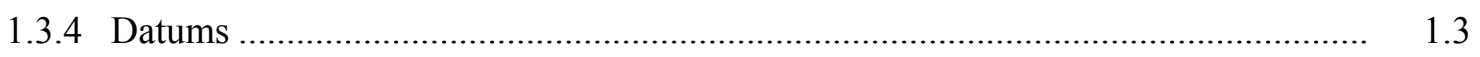

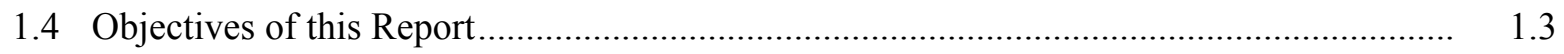

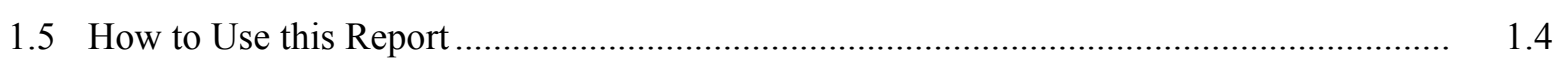

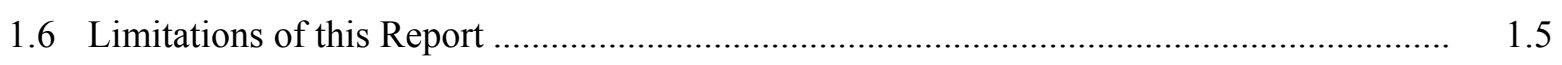

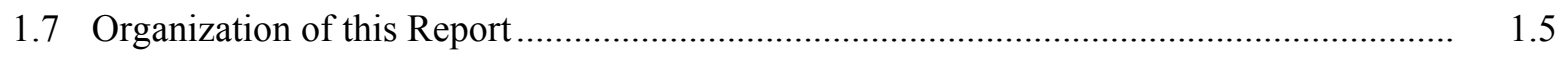

2.0 Characteristics of Tidal Wetland Ecosystems of the Lower Columbia River and Estuary .......... 2.1

2.1 Data Collection Methods...................................................................................... 2.1

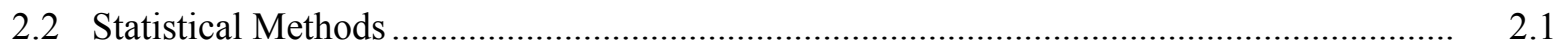

2.2.1 Emergent Marsh Zones ............................................................................... 2.2

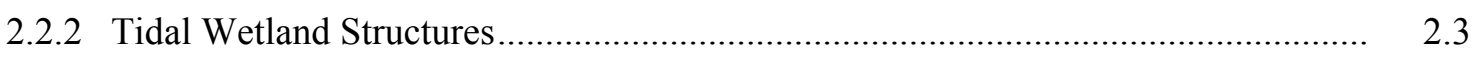

2.2.3 Tidal Wetland Processes ............................................................................ 2.5

2.2.4 Tidal Wetland Habitat Characteristics ............................................................. 2.6

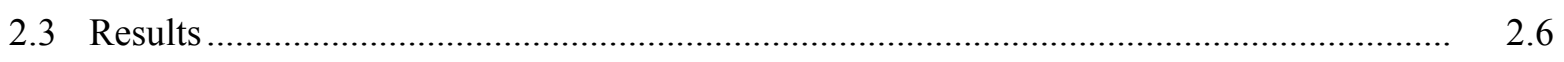

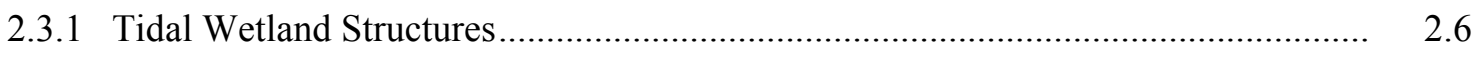

2.3.2 Tidal Wetland Processes ........................................................................... 2.32

2.3.3 Tidal Wetland Habitat Functions for Juvenile Salmon ...................................... 2.36

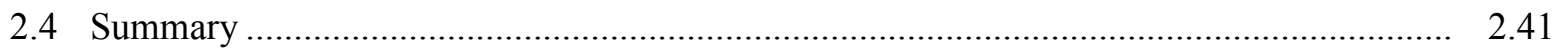

3.0 Disturbance History of Reference Wetlands ...............................................................

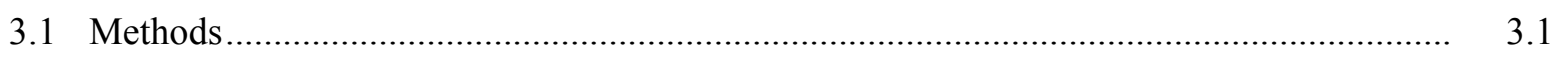

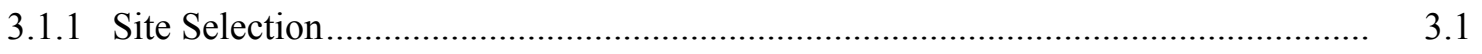

3.1.2 Land-Cover Data Analysis .......................................................................... 3.1

3.1.3 Disturbance History Classification ................................................................. 3.1

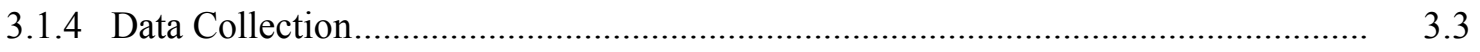

3.1.5 Measurement of Distance to Main Channel ….................................................. 3.4

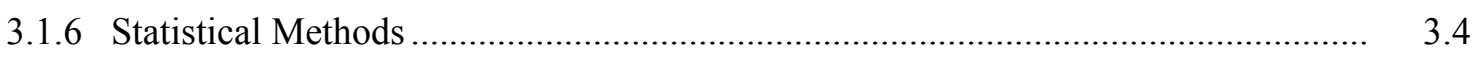

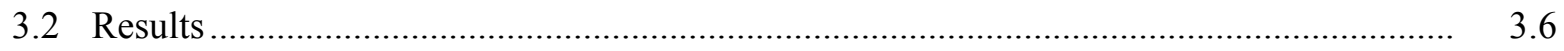


3.2.1 Land-Cover Data Analysis and Disturbance Level ........................................... 3.6

3.2.2 Landscape Position: Distance from the Main Channel of the Columbia River........ 3.9

3.2.3 Landscape Position: Average Site Elevation and Proportion of Low Marsh ............ $\quad 3.9$

3.2.4 Physical Controlling Factors and Ecosystem Processes....................................... 3.11

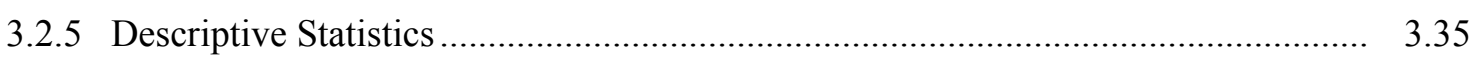

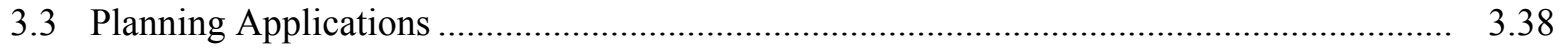

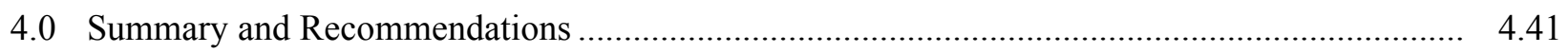

4.1 Summary - Planning Tools .................................................................................... 4.41

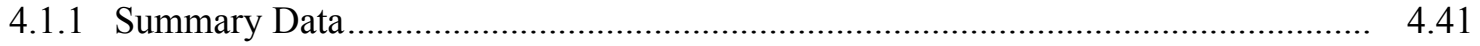

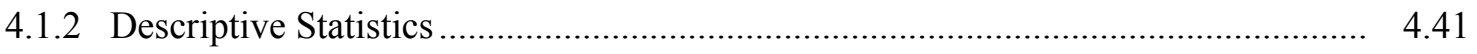

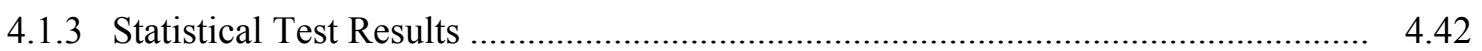

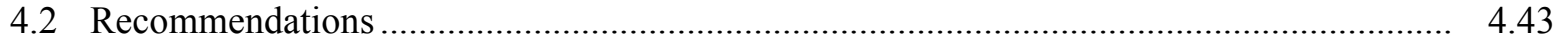

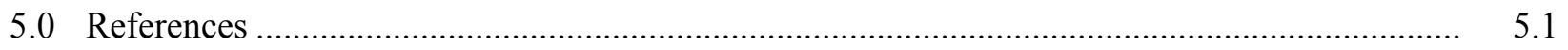




\section{Figures}

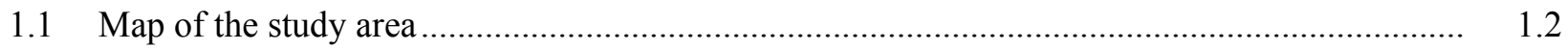

2.1 Scatter plot of the discriminant scores for five emergent marsh zones.................................... 2.3

2.2 Average site elevation of the vegetated sample area for emergent marshes along the estuarine gradient

2.3 Average site elevation of the vegetated sample area for emergent marshes along the estuarine gradient and average water level at emergent marshes on the main-stem river from years 2009 and 2010.

2.4 The range of elevation of major plants with increasing distance from the Columbia River mouth

2.5 (a) Elevation maximum and minimum of the 36 marsh plants observed in the most environmental conditions, as determined by presence in the largest number of emergent marsh zones and wetland types. (b) Elevation maximum and minimum of 27 herbaceous plants observed in forested and shrub-dominated wetland types...

2.6 (a) Segmented-regression analysis of average non-native herbaceous cover in main-stem marshes by river kilometer. (b) Average proportion of non-native herbaceous cover by river kilometer for all sites and years observed.

2.7 Average non-native herbaceous species cover by wetland type, in order from the earliest successional stage at the left.

2.8 Probability of reed canarygrass occurring with an average percent cover of more than $20 \%$ at each elevation.

2.9 Percentage of quadrats in which reed canarygrass occurred at $>20 \%$ cover by emergent marsh zone and by elevation

2.10 Average transect slope for study sites differentiated by location on the main-stem or a tributary and by wetland type.

2.11 Variation in sum exceedance value by site river kilometer.

2.12 Variation in sum exceedance value by average site elevation

2.13 Sum exceedance values along the elevation gradient, at selected sites from rkm 72 to rkm 201

2.14 Yearly sediment accretion/erosion rate at six wetland types.

2.15 Median 7-day average daily maximum water temperature at each site for the March 15-May 2 period, the May 3-June 20 period, and the August 22-October 9 period.

2.16 The channel width-to-depth ratios measured at the channel mouth in emergent marshes.

3.1 Examples of disturbance history analysis ....................................................................... 3.3

3.2 Distance to the main channel of sites in six disturbance categories........................................ 3.9

3.3 Average site elevation of sites in the disturbance categories............................................ 3.10

3.4 Proportion of low marsh at sites in the disturbance categories. ........................................... 3.10

3.5 The TOC in vegetated soils of marshes and level of disturbance.

3.6 Percent total organic carbon and ranked distance from the main channel, for marsh and tributary marsh floodplain soils and channel sediments 
3.7 Percent sand and fines in marsh and channel sediments at sites with ranked distance from the main channel

3.8 Thalweg elevations of marsh channels surveyed at the mouth. ......................................... 3.20

3.9 Width-to-depth ratio and cross-sectional area of marsh channels surveyed at the mouth. ......... 3.21

3.10 Root 1 and 2 of a discriminant function analysis of levels of disturbance............................... 3.27

3.11 Comparison of the discrimination of disturbance levels with the discrimination of emergent marsh zones using channel and floodplain characteristics.

3.12 Comparison of the discrimination of disturbance levels with the discrimination of emergent marsh zones using community characteristics

3.13 Dendrogram of average linkage, Euclidean distance between sites based on floodplain and channel characteristics.

3.14 Dendrogram of complete linkage, Euclidean distance between sites based on community characteristics, with disturbance history category in the bar below.

3.15 Disturbance code categorized nMDS plot of the Bray-Curtis similarity of sites based on the average plant cover of 35 species.

3.16 The likelihood of plant species presence in three disturbance categories 


\section{Tables}

1.1 Order and section pages for major results of tidal wetland ecosystem characterization and the exploration of driving variables.

2.1 Number of sites, transects, and quadrats sampled for plant cover.

2.2 Number of plant species observed during sampling by plant type.

2.3 Descriptive statistics of the average site elevation of herbaceous cover by wetland type including quartiles Q1 and Q3.

2.4 Descriptive statistics of the average site elevation of shrub and tree cover by wetland type......

2.5 Herbaceous species found in emergent marshes along the main stem of the river and the elevation ranges and locations along the LCRE where they were observed....

2.6 Herbaceous species found in emergent marshes along tributaries to the river in EM1, the elevation ranges, and the locations along the tributary where they were observed

2.7 Herbaceous and shrub species found in shrub wetlands along the main stem of the river, the elevation ranges, and locations along the LCRE where they were observed.

2.8 Herbaceous, shrub, and tree species found in evergreen forested wetlands along the main stem of the river and the elevation ranges and locations along the LCRE where they were observed

2.9 Herbaceous, shrub, and tree species found in evergreen forested wetlands along tributaries to the river and the elevation ranges and locations along the LCRE where they were observed

2.10 Herbaceous, shrub, and tree species found in deciduous forested wetlands along the main stem of the river and the elevation ranges and locations along the tributary where they were observed.....

2.11 Plant species that are among the most abundant plants and the most frequent plants

2.12 Minor plants present in marshes in more than one river section

2.13 Descriptive statistics for the average transect slope

2.14 Observed minimum and maximum of the growing season sum exceedance value by wetland type associated with elevations in which major herbaceous plant species occurred.....

2.15 Descriptive statistics of sediment accretion rate by wetland type and location within sites.

2.16 Average sediment accretion rates by EM zone for emergent main-stem marshes.

2.17 Median 7-DADMAX water temperature for all wetland types in five zones of the mainstem river and in tributaries to the estuary.

2.18 Channel morphology at the mouth and inundation frequencies from sites located in the LCRE floodplain...

3.1 Short descriptions of disturbance history categories, with numerical codes.......

3.2 Sites characteristics and results of land-cover analysis.

3.3 Floodplain and channel sediment characteristics of main-stem river and tributary marshes by disturbance category

3.4 Descriptive statistics of floodplain sediment characteristics by wetland type and location within site..... 
3.5 Descriptive statistics of channel sediment characteristics by wetland type and location within site.

3.6 Channel and floodplain characteristics

3.7 Channel morphology and floodplain characteristics for marshes.

3.8 Channel morphology and floodplain characteristics for forested and shrub wetlands

3.9 Kruskal-Wallis test of equal medians by disturbance level and regression test of slope equal to zero for all marshes

3.10 Community characteristics

3.11 Herbaceous plant species present at a minimum of ten quadrats in the lower Columbia River and estuary marsh data set, compared according to presence in dredged material placement sites and sites with local or landscape disturbances

3.12 Herbaceous plant species present at a minimum of 10 quadrats in the lower Columbia River and estuary marsh data set, compared according to cover in dredged material placement sites and sites with local or landscape disturbances

3.13 Sediment characteristics and significance of the differences between disturbance categories and the regression against the distance from the main channel.

3.14 Channel and floodplain morphology and significance of the differences between disturbance categories and the regression against the distance from the main channel.

3.15 Plant community characteristics and significance of the differences between disturbance categories for main-stem marshes in the LCRE and only within zones EM2 through EM5......

3.16 Summary of sites with an average site elevation below $1.5 \mathrm{~m}$, CRD relative to the average cover of reed canarygrass. Shaded rows indicate broad, low-elevation sloughs. 


\subsection{Introduction}

This report synthesizes and reanalyzes previously existing environmental and plant community data collected by Pacific Northwest National Laboratory (PNNL) at $55^{2}$ tidal wetlands and 3 newly restored sites in the lower Columbia River and estuary (LCRE) between 2005 and 2011. Whereas data were originally collected for various research or monitoring objectives of five studies, ${ }^{3}$ the intent of this report is to provide only information that will have direct utility in planning tidal wetland restoration projects. Therefore, for this report, all tidal wetland data on plants and the physical environment, which were originally developed and reported by separate studies, were reanalyzed as a whole. The intent of this report is to directly support ecosystem restoration planners ${ }^{4}$.

\subsection{Goals}

The goals of this study are twofold:

1. To characterize the environmental conditions required to restore and create tidal wetland plant communities in the LCRE similar to the least disturbed wetlands in the region, through synthesis of existing data on ecosystem structures, processes, and functions at reference wetlands.

2. To provide a basis for projecting successional trends at restored and created sites, through the synthesis, analysis, and comparison of existing data on ecosystem structures and processes at tidal wetlands in the LCRE using re-constructed histories of anthropogenic and natural disturbances.

\subsection{Geographic Scope}

We collected the data in tidal wetlands of the LCRE from Bonneville Lock and Dam to the mouth of the Columbia River, including tidally influenced low-elevation parts of tributary river floodplains such as the Grays River in Washington and the Lewis and Clark River in Oregon, although no wetlands in the lower Willamette River in Oregon were sampled (Figure 1.1).

\subsection{Technical Approach}

\subsubsection{Zonation or Wetland Position}

The analyses in this report necessarily consider spatial distribution, because of the complex longitudinal (river mouth to Bonneville Lock and Dam) and lateral (floodplain) gradients of environmental factors in the LCRE region. Five preliminary emergent marsh (EM) zones (EM1 through EM5), which were developed by the Lower Columbia Estuary Partnership (EP) Reference Site study

\footnotetext{
${ }^{2}$ Secret River marsh is counted as two sites, the high marsh and the low marsh.

${ }^{3}$ The data synthesized herein were primarily collected and reported under five research and monitoring studies: the EP's Ecosystem Monitoring Program and Reference Sites studies, funded by the Bonneville Power Administration (BPA); and the Corps of Engineers' Cumulative Effects (EST-02-P-04), Multi-Scale Research (EST-P-11-01) (formerly BPA Tidal Freshwater Monitoring [BPA 2005-001-00]), and Salmon Benefits (EST-P-09-1) studies.

${ }^{4}$ By the term "planner" we mean biologist, ecologist, hydrologist, engineer, or manager.
} 
through analysis of hydrodynamic regime and vegetation, are used as analytical categories to distinguish environmental data in this report (Borde et al. 2012a,b). Preliminary EM zones within selected river kilometer ( $\mathrm{rkm}$ ) ranges were developed based on the similarity in the plant community and hydrologic parameters using 22 less-disturbed marsh sites located between rkm 12 and rkm 230 and sampled between 2005 and 2010 (Figure 1.1). Salinity and large-scale hydrologic influence were characterized by the distance from the Columbia River mouth (in river kilometers); the EM1 has the greatest salinity influence. Zones were delineated based on plant distribution, regression analysis of the $\log _{10} \mathrm{sum}$ exceedance value (SEV) by river kilometer, and the relationship of the ratio of the growing season SEV to the full year SEV by marsh elevation (meters, Columbia River Datum [CRD]) (see Statistical Methods). Based on the statistical analysis, the EM1/EM2 boundary is located between 30 to $40 \mathrm{rkm}$ (Borde et al. 2012b; Jay et al. in review). The EM2/EM3 boundary is located between 70 and 108 rkm. The EM3/ EM4 boundary is estimated to be at $136 \mathrm{rkm}$, and the EM4/EM5 boundary is estimated to be at rkm 181 .

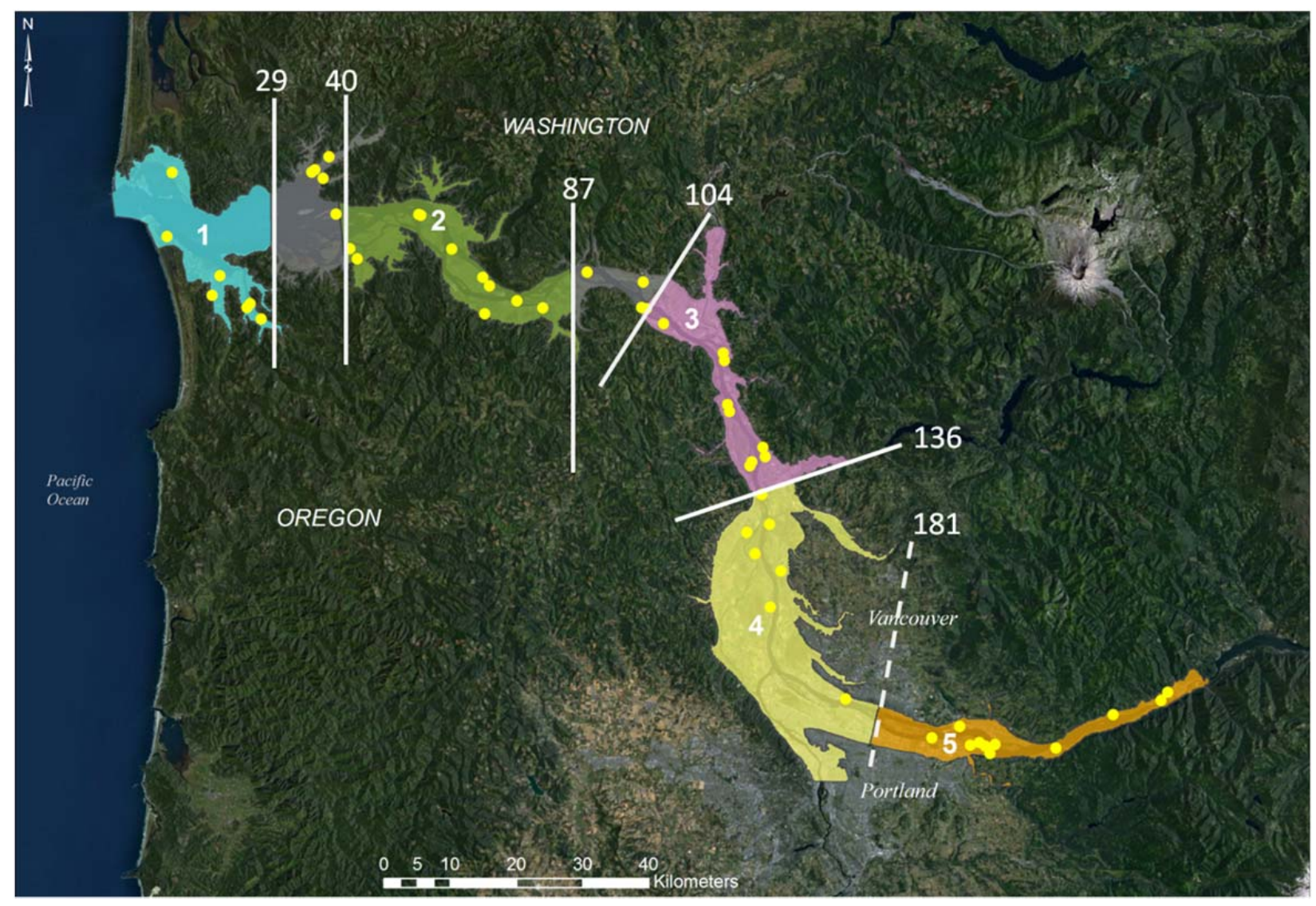

Figure 1.1. Map of the study area. The geographic scope of this report includes five emergent marsh zones. Transitional zones, where currently available data are insufficient to determine an accurate boundary, are indicated by gray areas between rkm 29 and rkm 40, and rkm 87 and rkm 104, and by a dashed line at rkm 181. The transition at rkm 181 is a preliminary hypothesis because there are very few study sites in the vicinity. Reference sites included in the study are represented by a yellow dot. Additional sites included in the study are recently restored Kandoll Farm on the Grays River in Washington, Crims Island on the main-stem Columbia River, and Vera Slough on Youngs Bay in Oregon.

In addition, analysis of the data confirmed that sites on tributary river floodplains differ from mainstem LCRE sites and should be analyzed and reported separately to produce the most accurate 
descriptions. All tributary sites sampled were located in EM1. Therefore, analyses in this report consider tributaries as a separate zone or a subset of EM1. Vertical zonation is also used in some analyses

\subsubsection{Wetland Types}

The data analyzed in this report are from reference sites including 43 main-stem EMs (including low and high marshes), 4 tributary emergent marshes, 2 deciduous shrub-dominated wetlands, 3 main-stem swamps (evergreen forested wetlands), 1 tributary swamp, and 2 deciduous forested wetlands located in riparian areas. Wetland types are estuarine intertidal or riverine tidal wetlands and were broadly classified according to Cowardin et al. (1979). Additionally, three recently reconnected sites are included in analyses where appropriate; these sites are undergoing rapid changes in physical and biological features, caused by restoration actions (Haskell et al. 2011, Johnson et al. 2012). Kandoll Farm is a tributary site with new culvert installation and dike breaching, located on the Grays River in Washington. Crims Island, on which channels and the floodplain surface were excavated, is located on the main-stem Columbia River. Vera Slough, with experimental tidegate installations, is located on Youngs Bay in Oregon. Bays are included in the main-stem river analyses for the purposes of this report, except where specified.

\subsubsection{Land Use History}

For the purpose of analyses in Section 3 of this report, we developed new categories of land use history centered on the geographic scale and types of disturbance processes that each site has experienced, as described in Section 3.

\subsubsection{Datums}

The elevation data synthesized were originally surveyed in the North American Vertical Datum of 1988 (NAVD88). We converted these data to the CRD for this analysis, because it provides the most useful comparison between main-stem wetlands. Below rkm 35.4, the CRD is not applicable because of tidal influence, so data were converted to mean lower low water (MLLW). Elevation data for sites located on tributaries to the LCRE are reported in NAVD88.

\subsection{Objectives of this Report}

The objectives of this report are twofold and correspond to the two goals. From the study Statement of Work, objectives are as follows:

1. "Quantitative specification of the ranges of a set of key structural, process, and functional attributes of reference sites. In effect, this will produce predictive relationships of direct application to restoration and creation project design." In brief, we refer to the content of this objective as focusing on "wetland ecosystem structures, processes, and functions."

2. "Development of long-term post-restoration trajectories characteristic of tidal wetlands in the LCRE using existing data, presented relative to the Corps' 50-year planning horizon. Data from existing historically breached sites and created islands will be arrayed on a temporal sequence (i.e., multiple sites, arrayed by year of wetland origin) to afford the opportunity to estimate timeframes for future recovery.” 
However, a surprising result emerged from the analyses of historical and present-day land-cover data that we performed to verify existing data intended for use in this report: only 3 of the 43 marsh reference sites previously sampled through the above-mentioned studies in the LCRE were present in 1870 - Secret River high and low marshes and Grant Island marsh. On the basis of this finding, and the lack of available complete historical aerial photo series of the LCRE, we determined that it was not possible, within the scope of this study, to correctly assign ages to the remaining 40 reference marshes and 12 other reference wetlands that we have sampled, to support the planned analyses of restoration trajectory. (The results of these land-cover data analyses are presented in this report.) Accordingly, the revised second objective of the analyses in this report is as follows: Classify tidally influenced wetlands of the LCRE by disturbance history, and examine the ability of this classification to discriminate ecological structures and processes, to provide a basis for determining successional trends as a result of restoration and creation actions.

In the future, through aerial photo analysis in coordination with the Corps' pile-dike inventory (AECOM 2011), it may be possible to assign ages to reference wetlands and definitively associate wetlands with pile dikes, and thereby to increase the temporal granularity of the analysis. Such an analysis would focus more on the successional development and change of wetland attributes at time scales from years to decades at created, previously diked, and relatively undisturbed sites, including sites affected by pile dikes, whereas the analyses herein use disturbance history to examine temporal effect.

\subsection{How to Use this Report}

The second section of this report provides information relevant to sites in the LCRE being considered for ecosystem restoration or creation, whether at the preliminary or feasibility study level. The emphasis is on providing data and principles to support planning, therefore we have organized the material as a resource for restoration planners. Wherever possible, figures and tables are ordered according to river kilometer, where rkm 0 is the mouth of the Columbia River and rkm 236 is at Bonneville Lock and Dam. In addition, the information about plant species elevation ranges provided in this report is intended to be used in two ways: native species elevations may provide suggested guidelines for planting or excavation, while non-native species elevations are provided to help preclude establishment.

In the preparation of the second chapter of this report, we assume that readers are familiar with the characteristics of tidal wetland ecosystems of the LCRE. The information in Chapter 2 constitutes analysis of the factors governing change within these ecosystems. This chapter provides information relevant to sites in the LCRE being considered for management actions such as ecosystem restoration or creation, whether at the preliminary or feasibility study level. Wherever possible, figures and tables are ordered by a disturbance history code and according to river kilometer, where rkm 0 is the mouth of the Columbia River and rkm 236 is at Bonneville Lock and Dam. The planner interested in a specific type of action, e.g., dredged material placement or dike breaching may find it helpful to use the disturbance history code to focus on the outcomes of sites that have undergone the same action in the past.

We recommend that the planner first identify the EM zone of the site of interest using Figure 1.1, and note whether it is located on a tributary to the LCRE in EM1, or on the main-stem river (including islands, river banks, and bays); this will facilitate referencing the tables and figures throughout this report. 


\subsection{Limitations of this Report}

Two factors in particular limit the analysis of environmental factors associated with level of disturbance in Section 3 of this report. First, the lack of a complete data set for site establishment year, or site age. Second, the lack of completely defined disturbance histories for each site, particularly in cases where multiple disturbances have occurred (e.g., pile-dike and dredged material placement). Site establishment age is further complicated in some cases at created sites if dredged material was deposited in multiple years.

In interpreting the information in this report, it is important to keep in mind that the LCRE region was subsampled; a census approach was not taken, so the continuity of environmental conditions between sampled sites along the river is statistically inferred, not directly measured. Sampling limitations are as follows. The largest sample size was for main-stem marshes $(n=43)$; all other wetland types have much smaller sample sizes $(n=1$ to $n=4)$. In general, elevations between $0.6 \mathrm{~m}, \mathrm{CRD}$ and $2.8 \mathrm{~m}, \mathrm{CRD}$ have greater representation in the sampling distribution. The upper elevation extent of Phalaris arundinacea (reed canarygrass) was not sampled at all sites in the synthesized studies, so this assessment does not attempt to define the upper boundary of this species. Submerged aquatic vegetation species were not comprehensively sampled in the synthesized studies, and only five species appear in descriptive statistics in this report: Elodea canadensis (Canada waterweed), Myriophylum species (milfoil), Potamogeton richardsonii (Richardson's pondweed), Potamogeton crispus (Longleaf pondweed), and Ceratophyllum demersum (Coontail). Data assessed in this report do not include any sites in tributary rivers above EM1; therefore, we do not recommend extending inferences from these findings to those tributaries. Furthermore, as yet, we cannot compare the elevations of the four tributary wetlands directly to mainstem wetlands, because it is not appropriate to apply the CRD to tributaries.

Despite these limitations, this is one of the largest sets of tidal wetland sites in the LCRE ever analyzed, and unlike many previous studies its distribution covers the study area relevant to the Biological Opinion (NMFS 2008) — from Bonneville Lock and Dam to the mouth of the river.

\subsection{Organization of this Report}

The organization of this report is intended to facilitate ease of use as a planning tool. It contains brief descriptions of the ecological rationales upon which our current understandings of the LCRE ecosystem are based, and provides references to project reports where this reasoning is further developed. Section 2-Characteristics of Tidal Wetland Ecosystems of the Lower Columbia River and Estuary - presents the field sampling and general statistical methods used to characterize tidal wetland structure, process, and function. Specific statistical assumptions and definitions are included within each subsection presenting the resulting characterization. Selected results that can be used for restoration planning are identified for ease of reference in Table 1.1. A summary is provided at the conclusion of the section.

Section 3-Disturbance History and Ecology of Reference Wetlands - is organized conventionally, with the methods used for data collection, synthesis, analysis, and statistics followed by the results. In addition, the first section of the results presents our comparative analysis of historical and present-day land-cover data. Potential planning applications of our findings are provided at the conclusion of the section and highlighted in Table 1.1. 
Section 4-Conclusions and Recommendations - is organized based on the planning tools that result from the characterization of the tidal wetland structure, process, and function of the LCRE and the exploration of driving variables that are hypothesized to generate the differences observed.

Table 1.1. Order and section pages for major results of tidal wetland ecosystem characterization and the exploration of driving variables.

\begin{tabular}{|c|c|c|c|}
\hline & Section & Figures and Tables & Pages \\
\hline \multirow{13}{*}{ 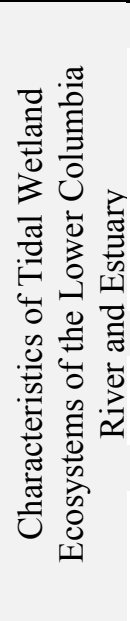 } & Tidal Wetland Structures & & \\
\hline & Wetland Elevation & Tables $2.3-2.4$ and Figures $2.2-2.3$ & $2.6-2.8$ \\
\hline & Elevation Range of Major Plant Species & Figure 2.4 & 2.18 \\
\hline & $\begin{array}{l}\text { Distribution of the Most Abundant and Most } \\
\text { Frequently Present Plant Species }\end{array}$ & Table 2.11 and Figure 2.5 & $2.19-2.26$ \\
\hline & Non-Native Plant Species & Figures $2.6-2.9$ & $2.27-2.30$ \\
\hline & Transect Slope & Table 2.13 and Figure 2.10 & $2.30-2.31$ \\
\hline & Tidal Wetland Processes & & \\
\hline & Spatial Variation of the Hydrologic Regime & Figures $2.11-2.13$ and Table 2.14 & $2.32-2.35$ \\
\hline & Sediment Accretion Rate & Tables $2.15-2.16$ and Figure 2.14 & $2.35-2.36$ \\
\hline & Tidal Wetland Habitat Characteristics & & \\
\hline & Water Temperature & Table 2.17 and Figure 2.15 & $2.36-2.38$ \\
\hline & Channel Morphology and Inundation & Table 2.18 and Figure 2.16 & $2.38-2.41$ \\
\hline & Summary & NA & 2.41 \\
\hline \multirow{11}{*}{ 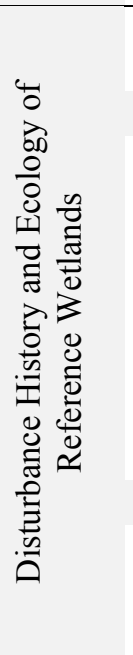 } & $\begin{array}{l}\text { Landscape Position: Average Site Elevation and } \\
\text { Proportion of Low Marsh }\end{array}$ & Figures 3.3-3.4 & $3.9-3.10$ \\
\hline & Physical Controlling Factors & & \\
\hline & Sediment Accretion Rate & Table 3.3 & 3.11 \\
\hline & $\begin{array}{l}\text { Sediment Grain Size and Total Organic Carbon, } \\
\text { and Level of Disturbance }\end{array}$ & Table 3.3 and Figures 3.5-3.6 & $3.11-3.13$ \\
\hline & $\begin{array}{l}\text { Sediment Grain Size, Total Organic Carbon, and } \\
\text { Wetland Type }\end{array}$ & Tables 3.4-3.5 & $3.13-3.14$ \\
\hline & $\begin{array}{l}\text { Sediment Grain Size, Total Organic Carbon, and } \\
\text { Distance from Main Channel }\end{array}$ & Figure 3.7 & $3.14-3.15$ \\
\hline & Channel Morphology & Table 3.6-3.9 and Figures 3.8-3.9 & $3.15-3.21$ \\
\hline & Plant Community Characteristics & & \\
\hline & Community Characteristics & Table 3.10 & $3.21-3.25$ \\
\hline & Plant Species Presence and Cover & Table $3.11-3.12$ and Figure 3.16 & $3.32-3.34$ \\
\hline & Summary & NA & 3.34 \\
\hline
\end{tabular}




\subsection{Characteristics of Tidal Wetland Ecosystems of the Lower Columbia River and Estuary}

The focus of this chapter is on characterizing the environmental conditions required to restore and create tidal wetland plant communities in the LCRE similar to the least disturbed wetlands in the region, through synthesis of existing data on ecosystem structures, processes, and functions at reference wetlands. Through the tables and analyses we develop quantitative specification of the ranges of a set of key structural, process, and functional attributes of reference sites. In effect, we show that much of the variability in the types and distribution of plant communities that occur in the LCRE is explained by elevation and hydrologic regime, while salinity is important only within the lowest EM zone.

\subsection{Data Collection Methods}

Most data were collected according to the Protocols for Monitoring Habitat Restoration Projects in The Lower Columbia River and Estuary (Roegner et al. 2009). Monitored indicators included: water surface elevation and temperature; herbaceous plant-cover and shrub and tree stem density; sediment accretion rate, grain size and total organic carbon (TOC); and channel cross sections. For plants, the field data collection at marsh sites focused on herbaceous vegetation within a 1 square meter $\left(\mathrm{m}^{2}\right)$ plot, although field notes and elevation measurements were made on shrub and tree species located within the plots or, more typically, above the marsh. Following Roegner et al. (2009), both herbaceous data in $1-\mathrm{m}^{2}$ plots and shrub data in 1-x 10-m plots were collected at shrub sites; at forested sites, 10-m-diameter circular tree plots were added to the herb and shrub sampling units.

Seven of the main-stem marsh sites were assessed for 2 or more years, with two sites assessed for 7 years. The remaining main-stem marsh sites and all other wetland types were assessed for 1 year. Typically, pressure gauges and sediment accretion stakes were deployed in July or August, and retrieved a year later when the remaining environmental data were collected.

It should be noted that data collected prior to completion of the protocols were used experimentally to develop the protocols by the Corps' Cumulative Effects study team, so methods varied somewhat prior to finalization of the protocols. Project-specific data collection information is available in the annual report series of the Corps' Cumulative Effects study (EST-02-P-04) (Johnson et al. 2011), and in the EP's Ecosystem Monitoring and Reference Sites reports (Borde et al. 2011, 2012a, 2012b; www.estuarypartnership.org).

\subsection{Statistical Methods}

The main objective of the exploratory statistical analysis was to estimate the likelihood of selected wetland plant species occurrence and cover by wetland type and associated with a range of structural, process, and functional characteristics, including hydrologic regime, slope and elevation, accretion/erosion rates, salinity influence, and water temperature. We evaluated plant relative cover (major, minor, and non-native) and plant presence/absence as a function of wetland type, EM zone, distance from the mouth, and elevation within a zone. The number of species (major and non-native) within a quadrat was evaluated as a function of slope and zone. Site characteristics including SEV, water temperature time series, water surface level time series, transect slope, sediment accretion rate and grain 
size were evaluated as a function of location within the river (rkm, zone, and wetland type). Sediment characteristics were compared between locations within the wetland defined by the plant strata and marsh and channel. Channel width and depth and other morphological characteristics were compared between zones.

Descriptive statistics, box plots, analysis of variance (ANOVA), and Tukey's multiple comparisons, and the nonparametric Kruskal-Wallis test on medians were generated in Minitab Version 16, Minitab Inc., 2010. Boxplots show the mean (points), median (horizontal line in the box), and the first quartile and third quartile (lower and upper bounds of the box). The length of the whiskers is defined as 1.5 times the interquartile difference (3rd quartile - 1st quartile) and asterisks represent a potential statistical outlier in the data set. For parametric analysis, assumptions of normality and homogeneity of within-class variance were assessed using normal probability and residual plots. Cover data were arcsine square root transformed to reduce within-class heterogeneity. When parametric assumptions could not be met or sample sizes were small $(\mathrm{n}<10)$, the nonparametric Kruskal-Wallis test and the Tukey's multiple comparisons test on the ranked data were used where appropriate. Regression analysis was conducted using Prism, Version 4.0, GraphPad Software Inc., 1992-2003.

The cover data we analyzed were collected from 55 selected sites between 2005 and 2011, and comprised 3518 quadrats from six wetland types designated as main-stem marsh, tributary marsh, mainstem swamp, tributary swamp, riparian, and shrub (Table 2.1). Seven of the sites were sampled two or more years.

Table 2.1. Number of sites, transects, and quadrats sampled for plant cover.

\begin{tabular}{lccccc}
\hline \multicolumn{1}{c}{ Type } & $\begin{array}{c}\text { Number of } \\
\text { Sites }\end{array}$ & $\begin{array}{c}\text { Number of } \\
\text { Transects }\end{array}$ & $\begin{array}{c}\text { Number of } \\
\text { Quadrats } \\
\text { with Plant Cover }\end{array}$ & $\begin{array}{c}\text { Number of Quadrats } \\
\text { with Elevations Used } \\
\text { in Slope Calculation }\end{array}$ & $\begin{array}{c}\text { Number of Transects } \\
\text { with a Constant } \\
\text { Slope }\end{array}$ \\
\hline Marsh & 43 & 241 & 2970 & 2871 & 161 \\
Riparian & 2 & 14 & 56 & 46 & 6 \\
Shrub & 2 & 17 & 79 & 78 & 6 \\
Swamp & 3 & 22 & 113 & 10 & 1 \\
Tributary Marsh & 4 & 23 & 93 & 93 & 4 \\
Tributary Swamp & 1 & 9 & 32 & 26 & 193 \\
Grand Total & 55 & 326 & 3343 & 3124 & 4 \\
\hline
\end{tabular}

\subsubsection{Emergent Marsh Zones}

Discriminant analysis was used to verify the distinction between zones (See Section 1.3.1) based on the cover of selected species. Despite $100 \%$ correct classification and excellent discrimination (Wilks Lambda $<0.0001, \mathrm{p}<0.0001$; Figure 2.1), there is uncertainty associated with the river kilometer cut-off values between zones because of the small number of relatively undisturbed marshes that have been evaluated. Thus, for the purposes of this analysis, boundaries between zones were wide as described in the technical approach (Figure 1.1). 


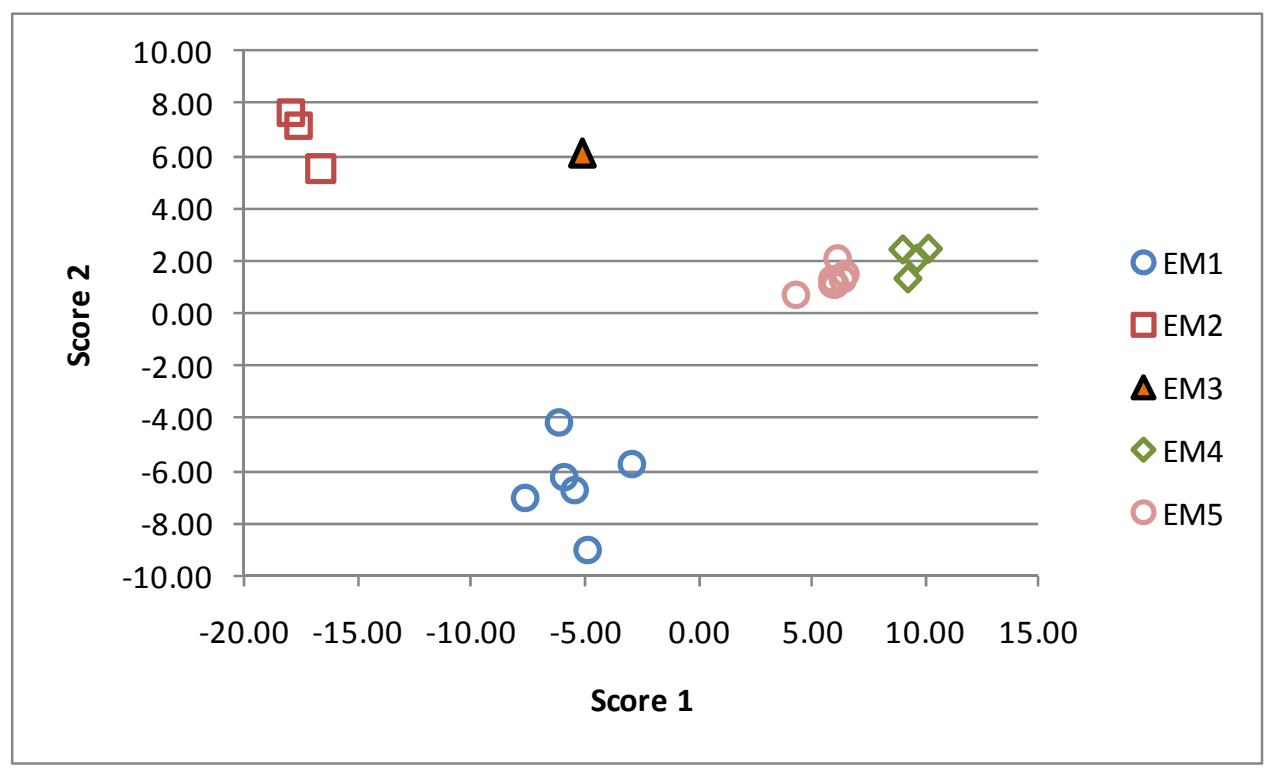

Figure 2.1. Scatter plot of the discriminant scores for five emergent marsh (EM) zones. The solid filled triangle was excluded from the discriminant analysis and scores were calculated as for a new observation.

\subsubsection{Tidal Wetland Structures}

\subsubsection{Plant Species Distribution, Abundance, and Presence/Absence by Wetland type and EM Zone}

The relative cover in each quadrat was calculated from the absolute cover for grasses, ferns, herbs, rushes, and sedges (181 species; Table 2.2). There were 155 species that were observed more than once and of those, 121 occurred at least once with cover $\geq 20 \%$. There were 92 species that occurred with the maximum cover ( $\geq 20 \%$ ) in one or more quadrats and only 78 species that occurred at $\geq 20 \%$ cover at more than one site. Of these 78 species, 63 species occurred as a maximum plant within a quadrat with a measured elevation and were selected for further analysis. Major plants for each wetland type were those observed as the maximum plant at more than one site (any type) within the river and at more than one elevation within a site. The 35 major plant species were characterized by river kilometer extent and range of elevation.

Table 2.2. Number of plant species observed during sampling by plant type (habit). Tree and shrub observations are included in this table only if they occurred in a $1-\mathrm{m}^{2}$ quadrat at a marsh site.

\begin{tabular}{|c|c|c|c|c|}
\hline Plant Type & $\begin{array}{c}\text { Count of } \\
\text { Species }\end{array}$ & $\begin{array}{c}\text { Maximum Absolute } \\
\text { Cover }(\%)\end{array}$ & $\begin{array}{l}\text { Used to Calculate } \\
\text { Total Plant Cover }\end{array}$ & $\begin{array}{c}\text { Number of } \\
\text { Quadrats Observed }\end{array}$ \\
\hline \multicolumn{5}{|c|}{ Plants Observed in Few Quadrats (No Further Analysis) } \\
\hline Algae & 2 & 20 & No & \\
\hline Arrow-grass & 1 & 30 & No & \\
\hline Liverwort & 2 & 10 & No & 392 \\
\hline Shrub & 14 & 100 & No & \\
\hline Tree & 4 & 100 & No & \\
\hline
\end{tabular}


Table 2.2. (contd)

\begin{tabular}{|c|c|c|c|c|}
\hline Plant Type & $\begin{array}{c}\text { Count of } \\
\text { Species } \\
\end{array}$ & $\begin{array}{c}\text { Maximum Absolute } \\
\text { Cover }(\%)\end{array}$ & $\begin{array}{l}\text { Used to Calculate } \\
\text { Total Plant Cover }\end{array}$ & $\begin{array}{c}\text { Number of } \\
\text { Quadrats Observed }\end{array}$ \\
\hline \multicolumn{5}{|c|}{ Plants Observed in Many Quadrats (Included in Further Analyses) } \\
\hline Grass & 18 & 100 & Yes & \\
\hline Fern & 10 & 100 & Yes & \\
\hline Herb & 121 & 100 & Yes & 4981 \\
\hline Rush & 10 & 100 & Yes & \\
\hline Sedge & 21 & 100 & Yes & \\
\hline Grand Total & 203 & - & - & 3343 \\
\hline
\end{tabular}

\subsubsection{Non-Native Plant Species}

The proportion of cover within a quadrat composed of non-native species was calculated for all sites. The average non-native cover of all quadrats within a site was compared between wetland types, both visually with a boxplot and using the Kruskal-Wallis test. A segmented-regression analysis of the average proportion of non-native cover as a function of river kilometer was conducted using only marsh sites.

For all marsh and tributary marsh sites, the number of quadrats containing $>20 \%$ cover of reed canarygrass $(n=206$ between -0.4 and $4 \mathrm{~m}, \mathrm{CRD})$ were evaluated as a function of elevation and zone. The cumulative proportion of reed canarygrass observed at $>20 \%$ cover in a quadrat out of the total number of quadrats $(\mathrm{n}=524)$ was calculated. A chi-square analysis of the number of quadrats with reed canarygrass cover $>20 \%$ was conducted by zone and by elevation ranges of less than $1.5 \mathrm{~m}$, between 1.5 and $2.0 \mathrm{~m}$, between 2.0 and $3.0 \mathrm{~m}$, and between 3.0 and $4.0 \mathrm{~m}$, CRD.

\subsubsection{Transect Slope}

Slope stability is a function of the local sediment texture and vegetation, and landscape processes. The slope may affect the location and speed of sediment deposition, and possibly the efficiency of nutrient exchange (the rate of infiltration). The absolute value of the slope between quadrats $(\mathrm{n}=3124)$ was calculated for all wetland sites with measured elevations. Calculations were conducted in one direction using increasing window sizes starting with nearest neighbors ( 2 consecutive quadrats) to a maximum window size of 12 consecutive quadrats along a given transect. A transect with 10 quadrats, for example, would produce 45 slope measurements $(9+8+7+6+5+4+3+2+1)$. The average slope (using all quadrats from a transect) and intercept were also calculated; however, because transects often went across the wetland channel, this slope was not always an appropriate descriptor of the marsh plain. A scatter plot of the elevation as a function of the quadrat location and a regression line were used to determine if the average slope could be used as a valid descriptor.

Local variability in slope was calculated as the standard deviation of the slopes produced using window sizes of 2 to 5 consecutive observations along a transect. An average standard deviation of the slopes between nearest neighbors (window size of 2) was also calculated. The mean standard deviation of the nearest neighbor slopes was used to assess whether or not the average slope was an appropriate descriptor of the transect. When the mean standard deviation was small $(<0.028)$, then the average slope was considered an appropriate descriptor of the transect. Values greater than this may imply the need for more than one slope to describe the transect, and these cases were evaluated visually. The third quartile of the standard deviation distribution from transects when an average slope was appropriate provides a 
nonparametric upper limit for when the average slope is appropriate. Values less than 0.03 would indicate that an average slope was an appropriate descriptor of the transect. Values greater than this may imply the need for more than one slope to describe the transect, and these cases were evaluated visually.

For all transects that were identified as being characterized by an average slope $(n=193)$, the elevation for all quadrats within a given site without a measured elevation was estimated using a two-step process. The first estimate, based on the average slope and intercept, was corrected based on the average difference between the observed and estimated values for those quadrats in the transect where elevation had been measured. This process only resulted in an additional 39 quadrats with an associated elevation. Descriptive statistics and a Kruskal-Wallis test were used to compare the average transect slope between wetland types.

\subsubsection{Tidal Wetland Processes}

\subsubsection{Spatial Variation of the Hydrologic Regime}

Spatial variation of the hydrologic regime was characterized using the SEV (sum exceedance value). The SEV was calculated using the following equation:

$$
\mathrm{SEV}=\sum_{i=1}^{n}\left(d_{\mathrm{i}}\right)
$$

where $n$ is the number of hours in the time period evaluated, and $d_{\mathrm{i}}$ is the hourly water surface elevation above the average marsh elevation for the $i^{\text {th }}$ hour. The hourly water-level elevation was chosen to ensure we captured daily inundation fluctuations that occur in the more tidally dominated sites.

The growing season period was standardized for each year: April 22 to June 21 and August 20 to October 12 (total $=115$ days). The gap between June 21 and August 20 was caused by variability in sensor deployment dates, i.e. the period was selected to ensure availability of a complete record for all days at all stations. The growing season was based on the number of frost-free days for the region, as determined by the Natural Resource Conservation Service in the wetland determination table for Clark County, Washington (NRCS 2002). The Clark County growing season was used for all the sites in the estuary so that the inundation calculations are standardized to one period. When the water year data spans two years, the year that the freshet occurred was considered the year for which the SEV is representative.

The range of growing season SEV and temperature values for each wetland type was determined based on the maximum elevation extent of the major plants observed within each type and zone. A low and high marsh was designated at the $1.5 \mathrm{~m}, \mathrm{CRD}$ elevation based on the observed increase of reed canarygrass (Phalaris arundinacea [PHAR]) above this elevation. A regression analysis of the growing season SEV calculated at the average marsh elevation as a function of river kilometer and elevation within main-stem and tributary marshes $(n=35)$ was conducted.

\subsubsection{Sediment Accretion Rate}

Descriptive statistics of accretion rates were calculated for each wetland type. Accretion rate measurements were compared using the nonparametric Kruskal-Wallis test. 


\subsubsection{Tidal Wetland Habitat Characteristics}

\subsubsection{Water Temperature}

Median water temperature for each of three time periods was calculated from the smoothed 7DADMAX water temperature for each sensor $(n=35$ for the earliest periods and $n=31$ for the latest period used in the analysis). The 7DADMAX is the seven-day running average of the daily maximum temperatures, i.e. the maximum temperature of the target day is averaged with those of the three days preceding and the three days following that day. This metric reduces the effect of brief fluctuations on the determination of whether water temperature is suitable, and is used under the assumption that exposure to sublethal effects for a week is meaningful. There were not enough sensor data from the different wetland types within any given year to compare water temperature by wetland type. A regression analysis was used to compare the slope of the median water temperature as a function of river kilometer for each time period and year using all sites.

\subsubsection{Channel Morphology and Inundation}

The percentage of time each channel was inundated was calculated for the thalweg and top-of-bank elevations during two time periods. To estimate habitat opportunity for juvenile salmonids, water depth of $50 \mathrm{~cm}$ was added to the thalweg elevation of each cross section as an indicator of the amount of water adequate for fish use of the channel (Nichole Sather, Pacific Northwest National Laboratory, personal communication). Likewise, a 10-cm water depth was added to the top-of-bank elevation at each cross section to represent a minimum amount of water needed for fish to access the vegetation at the edge of the bank (Bottom et al. 2005; Kurt Fresh, National Oceanic and Atmospheric Administration, personal communication). The periods assessed were 1) the deployment period (generally July to July) and 2) the period from March 1 through July 31, which represented one important juvenile Chinook migration period as determined from data previously collected (Bottom et al. 2005; Sagar et al. 2011; Sather et al. 2011).

\subsection{Results}

\subsubsection{Tidal Wetland Structures}

\subsubsection{Wetland Elevation}

Wetlands sampled in the LCRE fall within a narrow elevation range of approximately $5.3 \mathrm{~m}, \mathrm{CRD}$, not including channel depth and submerged aquatic vegetation. We defined this range based on the minimum elevation of Callitriche heterophylla (water starwort), $0.4 \mathrm{~m}, \mathrm{CRD}$, and the maximum elevation of several shrub species (Cornus sericea, Rubus spectabilis, and Symphoricarpos albus), 5.7 m, CRD. Emergent marshes in the LCRE fall within a narrower range of approximately $3.4 \mathrm{~m}$, based on the same minimum elevation of $0.4 \mathrm{~m}, \mathrm{CRD}$ and the maximum elevation of Phalaris arundinacea (reed canarygrass), $3.8 \mathrm{~m}, \mathrm{CRD}$. The average site elevation of the typical main-stem herbaceous emergent marshes assessed for this report is $1.7 \mathrm{~m}, \mathrm{CRD}$ (range 1.0-2.6) and for tributary emergent marsh sites the average elevation is $2.36 \mathrm{~m}$ NAVD88 (range 2.1-2.6; Table 2.3). The average elevation of the herbaceous strata in shrub wetlands was $2.4 \mathrm{~m}, \mathrm{CRD}, 2.8 \mathrm{~m}, \mathrm{CRD}$ in evergreen forested wetlands, and $3.3 \mathrm{~m}, \mathrm{CRD}$ in deciduous forested wetlands (Table 2.3). The average elevation of the shrub strata was $2.4 \mathrm{~m}, \mathrm{CRD}$ in shrub wetlands, $3.1 \mathrm{~m}, \mathrm{CRD}$ in evergreen forested wetlands, and $3.5 \mathrm{~m}, \mathrm{CRD}$ in deciduous 
forested wetlands (Table 2.4). The average elevation of the tree strata was $3.4 \mathrm{~m}$ and $3.2 \mathrm{~m}$, CRD in evergreen and deciduous forested wetlands, respectively. The range of average site elevations of shrub wetlands was from 2.3 to $2.5 \mathrm{~m}, \mathrm{CRD}$; evergreen forested wetlands from 2.6-3.7 m, CRD; and deciduous forested wetlands 2.7-4.2 m, CRD (Table 2.3, Table 2.4).

Table 2.3. Descriptive statistics of the average site elevation ( $m, C R D)$ of herbaceous cover by wetland type including quartiles Q1 and Q3.

\begin{tabular}{|c|c|c|c|c|c|c|c|c|c|c|}
\hline Wetland Type & $\mathrm{N}$ & Mean & StDev & Minimum & Q1 & Median & Q3 & Maximum & Lower $95 \%$ CL & Upper 95\% CL \\
\hline Marsh & 50 & 1.67 & 0.44 & 0.98 & 1.33 & 1.56 & 1.94 & 3.31 & 1.54 & 1.79 \\
\hline Tributary Marsh ${ }^{(a)}$ & 4 & 2.36 & 0.25 & 2.07 & 2.11 & 2.37 & 2.59 & 2.62 & 1.96 & 2.75 \\
\hline Shrub & 2 & 2.35 & 0.12 & 2.27 & (b) & 2.35 & (b) & 2.44 & (b) & (b) \\
\hline Evergreen Forested $^{(\mathrm{c})}$ & 4 & 2.84 & 0.17 & 2.63 & 2.76 & 2.85 & 2.94 & 3.02 & 2.57 & 3.10 \\
\hline Deciduous Forested & 2 & 3.25 & 0.81 & 2.68 & (b) & 3.25 & (b) & 3.82 & (b) & (b) \\
\hline
\end{tabular}

(a) Elevation data relative to NAVD88

(b) confidence limits were not calculated for sample sizes less than 4

(c) Average includes one site surveyed relative to NAVD88.

$\mathrm{CL}=$ confidence limit

Table 2.4. Descriptive statistics of the average site elevation of shrub and tree cover by wetland type.

\begin{tabular}{|c|c|c|c|c|c|c|c|c|c|c|c|}
\hline Variable & Type & $\mathrm{N}$ & Mean & StDev & Minimum & Q1 & Median & Q3 & Maximum & $\begin{array}{c}\text { Lower } 95 \% \\
\text { CL }\end{array}$ & $\begin{array}{c}\text { Upper } 95 \% \\
\text { CL }\end{array}$ \\
\hline \multirow[t]{3}{*}{ Shrub } & Shrub & 2 & 2.43 & 0.05 & 2.40 & (a) & 2.43 & (a) & 2.47 & (a) & (a) \\
\hline & Evergreen Forested & 4 & 3.11 & 0.31 & 2.71 & 3.02 & 3.13 & 3.22 & 3.47 & 2.61 & 3.60 \\
\hline & Deciduous Forested & 2 & 3.49 & 1.01 & 2.77 & (a) & 3.49 & (a) & 4.20 & (a) & (a) \\
\hline \multirow[t]{2}{*}{ Tree } & Evergreen Forested & 4 & 3.38 & 0.29 & 3.00 & 3.23 & 3.42 & 3.58 & 3.66 & 2.91 & 3.84 \\
\hline & Deciduous Forested & 2 & 3.18 & 0.85 & 2.58 & (a) & 3.18 & (a) & 3.78 & (a) & (a) \\
\hline
\end{tabular}

(a) confidence limits were not calculated for sample sizes less than 4

$\mathrm{CL}=$ confidence limit

The average emergent marsh site elevation in m NAVD88 significantly increases with river kilometer (regression; $\mathrm{n}=52 ; \mathrm{p}<0.001)$; however, the simple linear model does not fit well $\left(\mathrm{R}^{2}=71 \%\right.$, nonparametric goodness-of-fit, $\mathrm{p}=0.004$, Figure 2.2). A segmented regression using two linear models with a single join point fit the data well $\left(\mathrm{R}^{2}=83 \%\right.$, nonparametric goodness-of-fit, $\left.\mathrm{p}=0.07\right)$. The join point was estimated at rkm 112 (95\% confidence interval [CI]: 98 to 125) with the first slope from rkm 0 to $\mathrm{rkm} 112$ not significantly different from zero $(\mathrm{p}=0.07)$, and the second slope significantly different from zero ( $\mathrm{p}<0.001$; Figure 2.2). In contrast, the slope of the simple linear regression of the average emergent main-stem marsh site elevation in $\mathrm{m}, \mathrm{CRD}$ for those marshes above rkm 35 (below this, elevations are relative to MLLW) against the distance from the mouth of the Columbia River (km) was not significant (regression: $n=44 ; p=0.67$ ), which illustrates the effect of correcting elevations to the $\mathrm{CRD}$, a datum based on a low-water elevation (Figure 2.3). Hardy Creek marsh at rkm 230 is intermittently connected to the main-stem river with a site elevation of 6.31 NAVD88 (3.31 m, CRD), and was removed from this analysis because of its large influence on the regression. Water level ( $\mathrm{m}$, CRD) shows the same response as the average elevation (regression: $n=26 ; p=0.94$ ); similar water years were included in this analysis (Figure 2.3). 

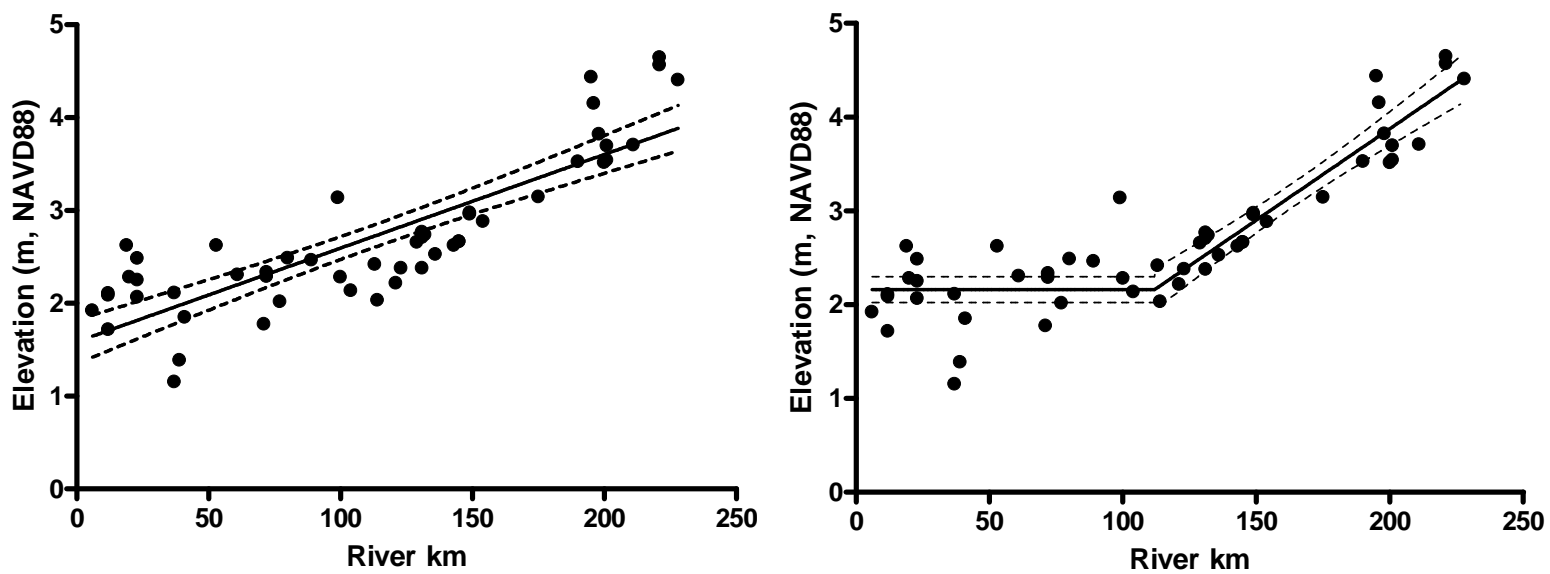

Figure 2.2. Average site elevation (m NAVD88) of the vegetated sample area for emergent marshes along the estuarine gradient. The fitted simple linear regression (left) and a segmented regression using two linear models (right) are shown with 95\% confidence intervals (CI; dashed line).
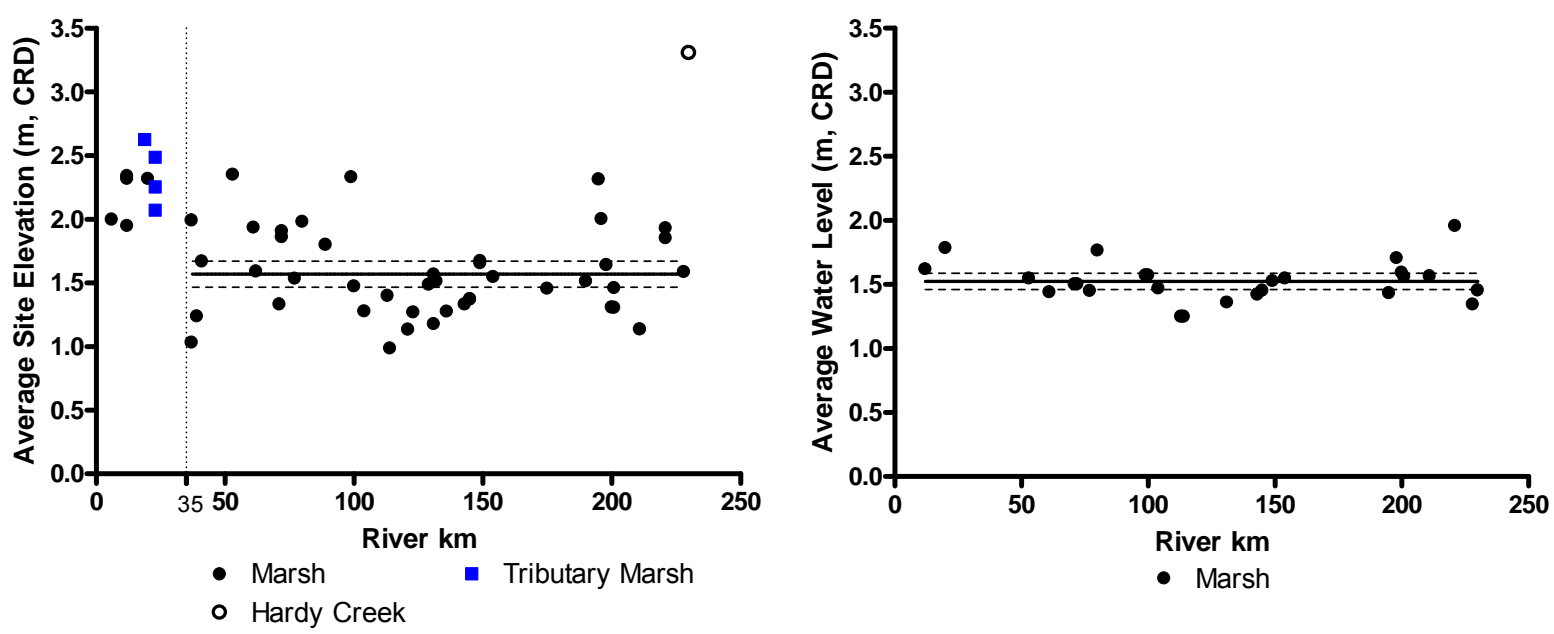

Figure 2.3. Average site elevation (m, CRD; below rkm $35 \mathrm{~m}$ MLLW; tributaries in NAVD88) of the vegetated sample area for emergent marshes along the estuarine gradient (left). Average water level (m, CRD) at emergent marshes on the main-stem river (right) from years 2009 and 2010. The fitted linear regression and its 95\% confidence interval (CI; dashed line).

The effects of elevation and inundation are intertwined and are examined together by the analyses in this report. Within an EM zone, elevation can be used as a proxy for inundation.

\subsubsection{Distribution of the Most Abundant Plant Species}

This section treats the distribution of plant species, including both vertical (elevation) range and spatial extent in the LCRE. We assessed data from a total of $35181-\mathrm{m}^{2}$ quadrats sampled between 2005 and 2011 at 55 tidal wetland sites. There are 43 main-stem marsh sites, 4 tributary marshes, 2 shrub sites, 3 swamp sites, 1 tributary swamp, and 2 riparian sites. 
Of the total number of quadrats assessed, 3343 quadrats contained identified grass, ferns, herbs, rushes, or sedges (see Statistical Methods); these data were used for the abundance analysis. All 3518 quadrats, some of which contained no plants, were used for the presence/absence analysis. A total of 3124 quadrats had elevation measurements surveyed, and, by using the slope, we estimated the elevation for 39 additional quadrats (see Statistical Methods), so a total of 3163 quadrats were included in elevation analyses.

The following tables are presented as a key reference to plant species in the LCRE for restoration planning: main-stem emergent marshes (Table 2.5), tributary emergent marshes (Table 2.6), main-stem shrub wetlands (Table 2.7), main-stem evergreen forested wetlands (Table 2.8), tributary evergreen forested wetlands (Table 2.9), and main-stem deciduous forested wetlands (Table 2.10). Herbaceous plant species included in the tables are those that had a maximum cover $>20 \%$ in a quadrat and occurred at more than one site in the study area; therefore, species that occur at low cover, yet are common throughout the area, may not be represented. These six tables present the river extent on which each emergent marsh plant species was observed (range of river kilometers) as well as the elevation range at which a species was observed. The tables can therefore be used as a guide to the longitudinal and vertical distributions at which plant species are likely to survive in the region. The tables provide additional information important to planning including whether the plant species is native or not, invasive/weedy, and its wetland status (e.g., facultative, obligate, etc.); the invasive/weedy determination is at a preliminary stage. The tables are ordered according to four-letter plant species codes composed of the first two letters of the genus and the species, which may also be used for reference to interpret figures and tables appearing later in this report.

The elevation distribution of plant species that occurred as the maximum plant at least 10 times was examined. A major plant was defined as having the maximum cover in a quadrat, and percent cover $>20 \%$ within a quadrat. The change in the range of elevation of these maximum plants with increasing distance from the Columbia River mouth was estimated (Figure 2.4). The slope of the simple linear regression of the maximum observed elevation against the distance from the mouth of the Columbia River (in river kilometers) was significant $(\mathrm{p}<0.05)$ for three of the plant species: reed canarygrass $(\mathrm{PHAR})$, common spikerush (Eleocharis palustris [ELPA]), and Lyngby sedge (Carex lyngbyei [CALY]). The regression of the minimum observed elevation against the distance from the mouth of the Columbia River was significant for only one plant species (CALY; regression, $n=9, p=0.046$ ). The regression analysis of the maximum elevation of reed canarygrass should be interpreted with caution, because the wetland sampling area at many sites did not include the upper extent of this species. In general, observations outside the confidence intervals are tributary sites. 
Table 2.5. Herbaceous species found in emergent marshes along the main stem of the river and the elevation ranges (m, CRD) and locations along the LCRE where they were observed. Species in the table are those that had a maximum cover in a quadrat and occurred at more than one site in the study area.

\begin{tabular}{|c|c|c|c|c|c|c|c|c|c|c|c|}
\hline \multirow[b]{2}{*}{ Zone } & \multirow[b]{2}{*}{$\begin{array}{l}\text { Plant } \\
\text { Code }\end{array}$} & \multirow[b]{2}{*}{ Scientific Name } & \multirow[b]{2}{*}{ Common Name } & \multirow[b]{2}{*}{$\begin{array}{l}\text { Wetland } \\
\text { Status }\end{array}$} & \multirow[b]{2}{*}{ Habit } & \multirow[b]{2}{*}{ Native } & \multirow[b]{2}{*}{$\begin{array}{l}\text { Invasive/ } \\
\text { Weedy }\end{array}$} & \multicolumn{2}{|c|}{$\begin{array}{c}\text { River Extent } \\
\text { Observed }\end{array}$} & \multicolumn{2}{|c|}{$\begin{array}{l}\text { Elevation Range } \\
\text { Observed }\end{array}$} \\
\hline & & & & & & & & $\begin{array}{l}\text { Low } \\
\text { Rkm }\end{array}$ & $\begin{array}{l}\text { High } \\
\text { Rkm }\end{array}$ & Min & Max \\
\hline EM1 & CACA & Calamagrostis canadensis & Bluejoint & FACW+ & Grass & yes & - & 12 & 12 & 1.6 & 2.5 \\
\hline EM1 & CALY & Carex lyngbyei & Lyngby sedge & OBL & Sedge & yes & - & 6 & 20 & 1.0 & 2.7 \\
\hline EM2 & CALY & Carex lyngbyei & Lyngby sedge & OBL & Sedge & yes & - & 37 & 77 & 0.8 & 2.1 \\
\hline EM2 & CAOB & Carex obnupta & Slough sedge & OBL & Sedge & yes & - & 41 & 89 & 1.6 & 2.3 \\
\hline EM3 & CAOB & Carex obnupta & Slough sedge & OBL & Sedge & yes & - & 129 & 129 & 1.4 & 2.1 \\
\hline EM5 & $\mathrm{CAOB}$ & Carex obnupta & Slough sedge & OBL & Sedge & yes & - & 190 & 221 & 1.4 & 2.4 \\
\hline EM5 & CASP & Carex sp. & Carex & mixed & Sedge & yes & - & 211 & 228 & 1.2 & 2.3 \\
\hline EM5 & DISP & Digitaria sp. & Crabgrass & FACU & Grass & mixed & - & 190 & 201 & 0.9 & 2.2 \\
\hline EM2 & ELAC & Eleocharis acicularis & Needle spikerush & OBL & Sedge & yes & - & 39 & 104 & 1.0 & 1.4 \\
\hline EM3 & ELAC & Eleocharis acicularis & Needle spikerush & OBL & Sedge & yes & - & 131 & 145 & 1.1 & 1.7 \\
\hline EM2 & ELCA & Elodea canadensis & Canada waterweed & OBL & Herb & yes & - & 71 & 77 & 0.9 & 1.5 \\
\hline EM3 & ELCA & Elodea canadensis & Canada waterweed & OBL & Herb & yes & - & 99 & 131 & -0.1 & 1.1 \\
\hline EM5 & ELCA & Elodea canadensis & Canada waterweed & OBL & Herb & yes & - & 196 & 198 & 0.7 & 2.1 \\
\hline EM2 & ELPA & Eleocharis palustris & Common spikerush & OBL & Sedge & yes & - & 71 & 89 & 1.1 & 1.8 \\
\hline EM3 & ELPA & Eleocharis palustris & Common spikerush & OBL & Sedge & yes & - & 99 & 132 & 0.6 & 1.6 \\
\hline EM4 & ELPA & Eleocharis palustris & Common spikerush & OBL & Sedge & yes & - & 136 & 154 & 0.8 & 1.8 \\
\hline EM5 & ELPA & Eleocharis palustris & Common spikerush & OBL & Sedge & yes & - & 190 & 228 & 0.6 & 2.2 \\
\hline EM5 & EUOC & Euthamia occidentalis & Western goldentop & $\mathrm{FACW}^{*}$ & Herb & yes & - & 190 & 198 & 1.6 & 3.2 \\
\hline EM2 & IRPS & Iris pseudacorus & Yellow iris & OBL & Herb & no & yes & 72 & 72 & 1.9 & 2.2 \\
\hline EM3 & IRPS & Iris pseudacorus & Yellow iris & OBL & Herb & no & yes & 114 & 136 & 1.1 & 1.7 \\
\hline EM3 & JUOX & Juncus oxymeris & Pointed rush & FACW+ & Rush & yes & - & 113 & 136 & 1.2 & 1.5 \\
\hline EM3 & LEOR & Leersia oryzoides & Rice cutgrass & OBL & Grass & yes & - & 123 & 123 & 1.3 & 1.5 \\
\hline EM5 & LEOR & Leersia oryzoides & Rice cutgrass & OBL & Grass & yes & - & 200 & 201 & 1.7 & 2.3 \\
\hline EM1 & LIOC & Lilaeopsis occidentalis & Western lilaeopsis & OBL & Herb & yes & - & 6 & 6 & 1.7 & 2.0 \\
\hline EM3 & LIOC & Lilaeopsis occidentalis & Western lilaeopsis & OBL & Herb & yes & - & 136 & 136 & 1.1 & 1.2 \\
\hline EM4 & LUPA & Ludwigia palustris & False loosestrife & OBL & Herb & yes & - & 136 & 175 & 0.9 & 1.5 \\
\hline EM2 & LYSA & Lythrum salicaria & Purple loosestrife & FACW+ & Herb & no & yes & 39 & 41 & 1.3 & 1.9 \\
\hline EM4 & LYSA & Lythrum salicaria & Purple loosestrife & FACW+ & Herb & no & yes & 175 & 175 & 1.1 & 2.0 \\
\hline
\end{tabular}


Table 2.5. (contd)

\begin{tabular}{|c|c|c|c|c|c|c|c|c|c|c|c|}
\hline \multirow[b]{2}{*}{ Zone } & \multirow[b]{2}{*}{$\begin{array}{l}\text { Plant } \\
\text { Code }\end{array}$} & \multirow[b]{2}{*}{ Scientific Name } & \multirow[b]{2}{*}{ Common Name } & \multirow[b]{2}{*}{$\begin{array}{l}\text { Wetland } \\
\text { Status }^{(\text {a) }}\end{array}$} & \multirow[b]{2}{*}{ Habit } & \multirow[b]{2}{*}{ Native } & \multirow[b]{2}{*}{$\begin{array}{l}\text { Invasive/ } \\
\text { Weedy }\end{array}$} & \multicolumn{2}{|c|}{$\begin{array}{l}\text { River Extent } \\
\text { Observed }\end{array}$} & \multicolumn{2}{|c|}{$\begin{array}{l}\text { Elevation Range } \\
\text { Observed }\end{array}$} \\
\hline & & & & & & & & $\begin{array}{l}\text { Low } \\
\text { Rkm }\end{array}$ & $\begin{array}{l}\text { High } \\
\text { Rkm }\end{array}$ & Min & Max \\
\hline EM2 & MYSP & Myosotis laxa, M. scorpioides & $\begin{array}{l}\text { Small forget-me-not, Common } \\
\text { forget-me-not }\end{array}$ & mixed & Herb & mixed & - & 39 & 89 & 1.1 & 1.9 \\
\hline EM5 & MYSP & Myosotis laxa, M. scorpioides & $\begin{array}{l}\text { Small forget-me-not, Common } \\
\text { forget-me-not }\end{array}$ & mixed & Herb & mixed & - & 198 & 198 & 0.6 & 0.6 \\
\hline EM3 & MYSP2 & Myriophyllum spp. & Milfoil & OBL & Herb & mixed & - & 114 & 114 & 0.7 & 1.0 \\
\hline EM1 & OESA & Oenanthe sarmentosa & Water parsley & OBL & Herb & yes & - & 20 & 37 & 1.2 & 2.7 \\
\hline EM1 & PHAR & Phalaris arundinacea & Reed canarygrass & FACW & Grass & no & yes & 20 & 20 & 2.5 & 2.7 \\
\hline EM2 & PHAR & Phalaris arundinacea & Reed canarygrass & FACW & Grass & no & yes & 37 & 80 & 1.3 & 2.3 \\
\hline EM3 & PHAR & Phalaris arundinacea & Reed canarygrass & FACW & Grass & no & yes & 99 & 132 & 1.1 & 2.6 \\
\hline EM4 & PHAR & Phalaris arundinacea & Reed canarygrass & FACW & Grass & no & yes & 136 & 175 & 1.2 & 3.8 \\
\hline EM5 & PHAR & Phalaris arundinacea & Reed canarygrass & FACW & Grass & no & yes & 190 & 230 & 1.1 & 3.6 \\
\hline EM3 & POHY & $\begin{array}{l}\text { Polygonum hydropiper, } P . \\
\text { hydropiperoides }\end{array}$ & $\begin{array}{l}\text { Waterpepper, Mild waterpepper, } \\
\text { Swamp smartweed }\end{array}$ & OBL & Herb & mixed & no & 100 & 114 & 1.3 & 1.6 \\
\hline EM5 & POHY & $\begin{array}{l}\text { Polygonum hydropiper, } P . \\
\text { hydropiperoides }\end{array}$ & $\begin{array}{l}\text { Waterpepper, Mild waterpepper, } \\
\text { Swamp smartweed }\end{array}$ & OBL & Herb & mixed & no & 196 & 196 & 1.3 & 2.0 \\
\hline EM2 & POPE & Polygonum persicaria & Spotted ladysthumb & FACW & Herb & no & yes & 41 & 41 & 1.3 & 1.6 \\
\hline EM5 & POPE & Polygonum persicaria & Spotted ladysthumb & FACW & Herb & no & yes & 198 & 198 & 1.2 & 1.9 \\
\hline EM2 & SALA & Sagittaria latifolia & Wapato & OBL & Herb & yes & no & 71 & 80 & 0.8 & 1.3 \\
\hline EM3 & SALA & Sagittaria latifolia & Wapato & OBL & Herb & yes & no & 100 & 132 & 0.5 & 1.5 \\
\hline EM4 & SALA & Sagittaria latifolia & Wapato & OBL & Herb & yes & no & 143 & 175 & 0.8 & 2.6 \\
\hline EM5 & SALA & Sagittaria latifolia & Wapato & OBL & Herb & yes & no & 190 & 221 & 0.8 & 1.8 \\
\hline EM1 & SCAM & Schoenoplectus americanus & American bulrush & OBL & Sedge & yes & no & 12 & 12 & 1.6 & 1.8 \\
\hline EM3 & SCAM & Schoenoplectus americanus & American bulrush & OBL & Sedge & yes & no & 123 & 123 & 0.9 & 1.0 \\
\hline EM2 & SCTA & Schoenoplectus tabernaemontani & Softstem bulrush, Tule & OBL & Sedge & Yes & no & 37 & 37 & 1.0 & 1.0 \\
\hline EM5 & SCTA & Schoenoplectus tabernaemontani & Softstem bulrush, Tule & OBL & Sedge & Yes & no & 211 & 211 & 0.9 & 1.0 \\
\hline EM3 & SCTR & Schoenoplectus triqueter & Threesquare tule & OBL & Sedge & no & no & 104 & 123 & 0.9 & 1.2 \\
\hline EM2 & TYAN & Typha angustifolia & Narrowleaf cattail & OBL & Herb & no & no & 72 & 77 & 1.0 & 1.9 \\
\hline EM1 & TYLA & Typha latifolia & Common cattail & OBL & Herb & yes & no & 20 & 20 & 2.5 & 2.6 \\
\hline EM2 & TYLA & Typha latifolia & Common cattail & OBL & Herb & yes & no & 100 & 100 & 1.4 & 1.9 \\
\hline
\end{tabular}

(a) In this report, wetland status is defined by information in the U.S. Department of Agriculture plants database at http://plants.usda.gov/wetinfo.html\#categories. 
Table 2.6. Herbaceous species found in emergent marshes along tributaries to the river in EM1, the elevation ranges (m NAVD88), and the locations along the tributary where they were observed. Species in the table are those that had a maximum cover in a quadrat and occurred at more than one site in the study area.

\begin{tabular}{|c|c|c|c|c|c|c|c|c|c|c|c|}
\hline \multirow[b]{2}{*}{ Zone } & \multirow[b]{2}{*}{$\begin{array}{l}\text { Plant } \\
\text { Code }\end{array}$} & \multirow[b]{2}{*}{ Scientific Name } & \multirow[b]{2}{*}{ Common Name } & \multirow[b]{2}{*}{$\begin{array}{l}\text { Wetland } \\
\text { Status }\end{array}$} & \multirow[b]{2}{*}{ Habit } & \multirow[b]{2}{*}{ Native } & \multirow[b]{2}{*}{$\begin{array}{l}\text { Invasive/ } \\
\text { Weedy }\end{array}$} & \multicolumn{2}{|c|}{$\begin{array}{l}\text { River Extent } \\
\text { Observed }^{(a)}\end{array}$} & \multicolumn{2}{|c|}{$\begin{array}{l}\text { Elevation Range } \\
\text { Observed }\end{array}$} \\
\hline & & & & & & & & $\begin{array}{l}\text { Low } \\
\text { Rkm }\end{array}$ & $\begin{array}{l}\text { High } \\
\text { Rkm }\end{array}$ & Min & $\operatorname{Max}$ \\
\hline EM1 & ATFI & Athyrium filix-femina & Lady fern & FAC & Fern & yes & - & 23 & 23 & 2.4 & 2.8 \\
\hline EM1 & CALY & Carex lyngbyei & Lyngby sedge & OBL & Sedge & yes & - & 23 & 23 & 1.0 & 2.6 \\
\hline EM1 & $\mathrm{CAOB}$ & Carex obnupta & Slough sedge & OBL & Sedge & yes & - & 19 & 23 & 1.7 & 2.7 \\
\hline EM1 & ELPA & Eleocharis palustris & Common spikerush & OBL & Sedge & yes & - & 23 & 23 & 2.1 & 2.3 \\
\hline EM1 & MYSP2 & Myriophyllum spp. & Milfoil & OBL & Herb & mixed & - & 23 & 23 & 0.5 & 2.2 \\
\hline EM1 & PHAR & Phalaris arundinacea & Reed canarygrass & FACW & Grass & no & yes & 19 & 23 & 2.3 & 2.7 \\
\hline EM1 & POAN & $\begin{array}{l}\text { Potentilla anserina ssp. } \\
\text { Pacifica/Argentina egedii ssp. Egedii }\end{array}$ & Pacific silverweed & OBL & Herb & yes & - & 23 & 23 & 2.5 & 2.7 \\
\hline EM1 & POHY & $\begin{array}{l}\text { Polygonum hydropiper, } P \text {. } \\
\text { hydropiperoides }\end{array}$ & $\begin{array}{l}\text { Waterpepper, Mild waterpepper, } \\
\text { Swamp smartweed }\end{array}$ & OBL & Herb & mixed & - & 23 & 23 & 2.4 & 2.4 \\
\hline EM1 & SCTA & Schoenoplectus tabernaemontani & Softstem bulrush, Tule & OBL & Sedge & Yes & - & 23 & 23 & 2.2 & 2.6 \\
\hline
\end{tabular}


Table 2.7. Herbaceous and shrub species found in shrub wetlands along the main stem of the river (in EM2), the elevation ranges ( $\mathrm{m}$, CRD), and locations along the LCRE where they were observed. Herbaceous species in the table are those that had a maximum cover in a quadrat and occurred at more than one site in the study area. Shrub species in the table are present in at least one of the shrub sites, and have relative frequency and/or relative density $>15 \%$.

\begin{tabular}{|c|c|c|c|c|c|c|c|c|c|c|c|}
\hline \multirow[b]{2}{*}{ Zone } & \multirow[b]{2}{*}{$\begin{array}{l}\text { Plant } \\
\text { Code }\end{array}$} & \multirow[b]{2}{*}{ Scientific Name } & \multirow[b]{2}{*}{ Common Name } & \multirow[b]{2}{*}{$\begin{array}{c}\text { Wetland } \\
\text { Status }\end{array}$} & \multirow[b]{2}{*}{ Habit } & \multirow[b]{2}{*}{ Native } & \multirow[b]{2}{*}{$\begin{array}{l}\text { Invasive/ } \\
\text { Weedy }\end{array}$} & \multicolumn{2}{|c|}{$\begin{array}{l}\text { River Extent } \\
\text { Observed }\end{array}$} & \multicolumn{2}{|c|}{$\begin{array}{l}\text { Elevation } \\
\text { Range } \\
\text { Observed }\end{array}$} \\
\hline & & & & & & & & $\begin{array}{l}\text { Low } \\
\text { Rkm }\end{array}$ & $\begin{array}{l}\text { High } \\
\text { Rkm }\end{array}$ & Min & $\operatorname{Max}$ \\
\hline \multicolumn{12}{|c|}{ Herbaceous Species } \\
\hline EM2 & CAHE & Callitriche heterophylla & $\begin{array}{l}\text { Water starwort, Two headed water } \\
\text { starwort }\end{array}$ & OBL & Herb & yes & - & 53 & 53 & 0.9 & 1.0 \\
\hline EM2 & IMSP & $\begin{array}{l}\text { Impatiens capensis,Impatiens } \\
\text { noli-tangere }\end{array}$ & $\begin{array}{l}\text { Spotted touch-me-not, Common touch- } \\
\text { me-not }\end{array}$ & FACW & Herb & yes & - & 53 & 73 & 2.0 & 2.7 \\
\hline EM2 & LYAM & Lysichiton americanus & Skunk cabbage & OBL & Herb & yes & - & 53 & 73 & 2.0 & 3.3 \\
\hline EM2 & MYSP & Myosotis laxa, M. scorpioides & $\begin{array}{l}\text { Small forget-me-not, Common forget- } \\
\text { me-not }\end{array}$ & mixed & Herb & mixed & - & 53 & 53 & 2.2 & 2.3 \\
\hline EM2 & PHAR & Phalaris arundinacea & Reed canarygrass & FACW & Grass & no & yes & 53 & 73 & 1.1 & 2.4 \\
\hline EM2 & PORI & Potamogeton richardsonii & Richardson's pondweed & OBL & Herb & yes & - & 53 & 53 & 0.6 & 0.7 \\
\hline \multicolumn{12}{|c|}{ Shrub Species } \\
\hline EM2 & COSE & Cornus sericea & Red-osier dogwood & FACW & Shrub & yes & - & 53 & 73 & 2.0 & 2.9 \\
\hline EM2 & RUUR & Rubus ursinus & Trailing blackberry & FACU & Shrub & yes & - & 53 & 73 & 2.0 & 2.9 \\
\hline EM2 & SASI & Salix sitchensis & Sitka willow & FACW & Shrub & yes & - & 73 & 73 & 1.6 & 2.6 \\
\hline
\end{tabular}


Table 2.8. Herbaceous, shrub, and tree species found in evergreen forested wetlands (swamps) along the main stem of the river and the elevation ranges $(\mathrm{m}, \mathrm{CRD})$ and locations along the LCRE where they were observed. Herbaceous species in the table are those that had a

maximum cover in a quadrat and occurred at more than one site in the study area. Shrub species in the table are present in at least one of the shrub sites, and have relative frequency and/or relative density $>15 \%$. Tree species in the table are present in at least one of the six forested sites, and have relative frequency, relative density, and/or relative dominance $>15 \%$.

\begin{tabular}{|c|c|c|c|c|c|c|c|c|c|c|c|}
\hline \multirow[b]{2}{*}{ Zone } & \multirow[b]{2}{*}{$\begin{array}{l}\text { Plant } \\
\text { Code }\end{array}$} & \multirow[b]{2}{*}{ Scientific Name } & \multirow[b]{2}{*}{ Common Name } & \multirow[b]{2}{*}{$\begin{array}{l}\text { Wetland } \\
\text { Status }\end{array}$} & \multirow[b]{2}{*}{ Habit } & \multirow[b]{2}{*}{ Native } & \multirow[b]{2}{*}{$\begin{array}{l}\text { Invasive/ } \\
\text { Weedy }\end{array}$} & \multicolumn{2}{|c|}{$\begin{array}{l}\text { River Extent } \\
\text { Observed }\end{array}$} & \multicolumn{2}{|c|}{$\begin{array}{c}\text { Elevation Range } \\
\text { Observed }\end{array}$} \\
\hline & & & & & & & & $\begin{array}{l}\text { Low } \\
\text { Rkm }\end{array}$ & $\begin{array}{l}\text { High } \\
\text { Rkm }\end{array}$ & Min & Max \\
\hline \multicolumn{12}{|c|}{ Herbaceous Species } \\
\hline$<70 \mathrm{rkm}$ & ATFI & Athyrium filix-femina & Lady fern & FAC & Fern & yes & - & 37 & 40 & & \\
\hline$<70 \mathrm{rkm}$ & CAHE & Callitriche heterophylla & Water starwort, Two headed water starwort & OBL & Herb & yes & - & 37 & 37 & 2.7 & 3.5 \\
\hline$<70 \mathrm{rkm}$ & $\mathrm{CAOB}$ & Carex obnupta & Slough sedge & OBL & Sedge & yes & - & 37 & 37 & 2.6 & 2.6 \\
\hline$<70 \mathrm{rkm}$ & IMSP & $\begin{array}{l}\text { Impatiens capensis,Impatiens } \\
\text { noli-tangere }\end{array}$ & Spotted touch-me-not, Common touch-me-not & FACW & Herb & yes & - & 40 & 40 & $\begin{array}{l}2.5 \\
2.5\end{array}$ & $\begin{array}{l}3.1 \\
2.6\end{array}$ \\
\hline$<70 \mathrm{rkm}$ & LYAM & Lysichiton americanus & Skunk cabbage & OBL & Herb & yes & - & 37 & 40 & 2.3 & 3.3 \\
\hline$<70 \mathrm{rkm}$ & PHAR & Phalaris arundinacea & Reed canarygrass & FACW & Grass & no & yes & 37 & 37 & 3.0 & 3.5 \\
\hline$<70 \mathrm{rkm}$ & POMU & Polystichum munitum & Sword fern & FACU & Fern & yes & - & 37 & 37 & 2.9 & 3.8 \\
\hline \multicolumn{12}{|c|}{ Shrub Species } \\
\hline$<70 \mathrm{rkm}$ & GASH & Gaultheria shallon & Salal & FACU & Shrub & yes & - & 37 & 40 & 2.7 & 3.6 \\
\hline$<70 \mathrm{rkm}$ & OECE & Oemleria cerasiformis & Indian-plum & FACU & Shrub & yes & - & 37 & 37 & 3.3 & 3.3 \\
\hline$<70 \mathrm{rkm}$ & RUPA & Rubus parviflorus & Thimbleberry & FAC- & Shrub & yes & - & 37 & 37 & 2.6 & 2.8 \\
\hline$<70 \mathrm{rkm}$ & RUSP & Rubus spectabilis & Salmonberry & $\mathrm{FAC}+$ & Shrub & yes & - & 37 & 37 & 2.9 & 3.6 \\
\hline$<70$ rkm & RUUR & Rubus ursinus & Trailing blackberry & FACU & Shrub & yes & - & 37 & 40 & 2.3 & 2.7 \\
\hline \multicolumn{12}{|c|}{ Tree Species } \\
\hline$<70 \mathrm{rkm}$ & ALRU & Alnus rubra & Red alder & FAC & Tree & yes & - & 37 & 40 & 2.6 & 3.8 \\
\hline$<70 \mathrm{rkm}$ & FRPU & Frangula purshiana & Cascara & FAC- & Tree & yes & - & 40 & 40 & 3.1 & 3.1 \\
\hline$<70 \mathrm{rkm}$ & MAFU & Malus fusca & Pacific crab apple & FACW & Tree & yes & - & 37 & 40 & 3.0 & 3.4 \\
\hline$<70 \mathrm{rkm}$ & PISI & Picea sitchensis & Sitka spruce & FAC & Tree & yes & - & 37 & 40 & 2.2 & 5.0 \\
\hline
\end{tabular}


Table 2.9. Herbaceous, shrub, and tree species found in evergreen forested wetlands (swamps) along tributaries to the river and the elevation ranges (m NAVD88) and locations along the LCRE where they were observed. Herbaceous species in the table are those that had a maximum cover in a quadrat and occurred at more than one site in the study area. Shrub species in the table are present in at least one of the shrub sites, and have relative frequency and/or relative density $>15 \%$. Tree species in the table are present in at least one of the six forested sites, and have relative frequency, relative density, and/or relative dominance $>15 \%$.

\begin{tabular}{|c|c|c|c|c|c|c|c|c|c|c|c|}
\hline \multirow[b]{2}{*}{ Zone } & \multirow[b]{2}{*}{$\begin{array}{l}\text { Plant } \\
\text { Code } \\
\end{array}$} & \multirow[b]{2}{*}{ Scientific Name } & \multirow[b]{2}{*}{ Common Name } & \multirow[b]{2}{*}{$\begin{array}{l}\text { Wetland } \\
\text { Status }\end{array}$} & \multirow[b]{2}{*}{ Habit } & \multirow[b]{2}{*}{ Native } & \multirow[b]{2}{*}{$\begin{array}{c}\text { Invasive/ } \\
\text { Weedy }\end{array}$} & \multicolumn{2}{|c|}{$\begin{array}{c}\text { River Extent } \\
\text { Observed }\end{array}$} & \multicolumn{2}{|c|}{$\begin{array}{l}\text { Elevation } \\
\text { Range } \\
\text { Observed }\end{array}$} \\
\hline & & & & & & & & $\begin{array}{l}\text { Low } \\
\text { Rkm }\end{array}$ & $\begin{array}{l}\text { High } \\
\text { Rkm }\end{array}$ & Min & $\operatorname{Max}$ \\
\hline$<70 \mathrm{rkm}$ & ATFI & Athyrium filix-femina & Lady fern & FAC & Fern & yes & - & 37 & 37 & 2.8 & 3.1 \\
\hline$<70 \mathrm{rkm}$ & САOB & Carex obnupta & Slough sedge & OBL & Sedge & yes & - & 37 & 37 & 2.1 & 3.0 \\
\hline$<70 \mathrm{rkm}$ & IMSP & $\begin{array}{l}\text { Impatiens capensis,Impatiens noli- } \\
\text { tangere }\end{array}$ & Spotted touch-me-not, Common touch-me-not & FACW & Herb & yes & - & 37 & 37 & 2.6 & 2.7 \\
\hline$<70 \mathrm{rkm}$ & LYAM & Lysichiton americanus & Skunk cabbage & OBL & Herb & yes & - & 37 & 37 & 1.9 & 3.4 \\
\hline$<70 \mathrm{rkm}$ & OESA & Oenanthe sarmentosa & Water parsley & OBL & Herb & yes & - & 37 & 37 & 2.7 & 3.2 \\
\hline \multicolumn{12}{|c|}{ Shrub Species } \\
\hline$<70 \mathrm{rkm}$ & GASH & Gaultheria shallon & Salal & FACU & Shrub & yes & - & 37 & 37 & 2.7 & 3.8 \\
\hline$<70 \mathrm{rkm}$ & RUSP & Rubus spectabilis & Salmonberry & FAC + & Shrub & yes & - & 37 & 37 & 2.7 & 3.8 \\
\hline \multicolumn{12}{|c|}{ Tree Species } \\
\hline$<70 \mathrm{rkm}$ & FRPU & Frangula purshiana & Cascara & FAC- & Tree & yes & - & 37 & 37 & 2.5 & 3.7 \\
\hline$<70 \mathrm{rkm}$ & MAFU & Malus fusca & Pacific crab apple & FACW & Tree & yes & - & 37 & 37 & 2.1 & 3.3 \\
\hline$<70$ rkm & PISI & Picea sitchensis & Sitka spruce & FAC & Tree & yes & - & 37 & 37 & 2.7 & 4.1 \\
\hline$<70 \mathrm{rkm}$ & THPL & Thuja plicata & Western redcedar & FAC & Tree & yes & - & 37 & 37 & 2.1 & 3.8 \\
\hline
\end{tabular}

(a) Distance from the mouth of the tributary to the mouth of the Columbia River. 
Table 2.10. Herbaceous, shrub, and tree species found in deciduous forested (riparian) wetlands along the main stem of the river and the elevation ranges (m, CRD) and locations along the tributary where they were observed. Species in the table are those that had a maximum cover in a quadrat and occurred at more than one site in the study area.

\begin{tabular}{|c|c|c|c|c|c|c|c|c|c|c|c|}
\hline \multirow[b]{2}{*}{ Zone } & \multirow[b]{2}{*}{$\begin{array}{l}\text { Plant } \\
\text { Code }\end{array}$} & \multirow[b]{2}{*}{ Scientific Name } & \multirow[b]{2}{*}{ Common Name } & \multirow[b]{2}{*}{$\begin{array}{l}\text { Wetland } \\
\text { Status }\end{array}$} & \multirow[b]{2}{*}{ Habit } & \multirow[b]{2}{*}{ Native } & \multirow[b]{2}{*}{$\begin{array}{l}\text { Invasive/ } \\
\text { Weedy }\end{array}$} & \multicolumn{2}{|c|}{$\begin{array}{l}\text { River Extent } \\
\text { Observed }\end{array}$} & \multicolumn{2}{|c|}{$\begin{array}{c}\text { Elevation Range } \\
\text { Observed }\end{array}$} \\
\hline & & & & & & & & $\begin{array}{l}\text { Low } \\
\text { Rkm }\end{array}$ & $\begin{array}{l}\text { High } \\
\text { Rkm }\end{array}$ & Min & Max \\
\hline$>70 \mathrm{rkm}$ & $\mathrm{CAOB}$ & Carex obnupta & Slough sedge & OBL & Sedge & yes & - & 98 & 98 & 2.7 & 3.0 \\
\hline$>70 \mathrm{rkm}$ & IMSP & $\begin{array}{l}\text { Impatiens capensis,Impatiens noli- } \\
\text { tangere }\end{array}$ & $\begin{array}{l}\text { Spotted touch-me-not, Common } \\
\text { touch-me-not }\end{array}$ & FACW & Herb & yes & - & 98 & 141 & 2.7 & 4.7 \\
\hline$>70 \mathrm{rkm}$ & PHAR & Phalaris arundinacea & Reed canarygrass & FACW & Grass & no & yes & 98 & 141 & 2.2 & 4.5 \\
\hline$>7$ 0rkm & URDI & Urtica dioica & Stinging Nettle & $\mathrm{FAC}+$ & Herb & yes & - & 141 & 141 & 3.8 & 5.3 \\
\hline \multicolumn{12}{|c|}{ Shrub Species } \\
\hline$>70 \mathrm{rkm}$ & COSE & Cornus sericea & Red-osier dogwood & FACW & Shrub & yes & - & 141 & 141 & 3.5 & 5.7 \\
\hline$>70 \mathrm{rkm}$ & LOIN & Lonicera involucrata & Black twinberry & FAC + & Shrub & yes & - & 98 & 98 & 2.3 & 2.9 \\
\hline$>70 \mathrm{rkm}$ & RUUR & Rubus ursinus & Trailing blackberry & FACU & Shrub & yes & - & 98 & 141 & 1.8 & 5.0 \\
\hline$>70 \mathrm{rkm}$ & RUSP & Rubus spectabilis & Salmonberry & FAC + & Shrub & yes & - & 141 & 141 & 3.7 & 5.7 \\
\hline$>70 \mathrm{rkm}$ & SYAL & Symphoricarpos albus & Common snowberry & FACU & Shrub & yes & - & 98 & 141 & 1.8 & 5.7 \\
\hline \multicolumn{12}{|c|}{ Tree Species } \\
\hline$>70 \mathrm{rkm}$ & FRLA & Fraxinus latifolia & Oregon ash & FACW & Tree & yes & - & 98 & 141 & 2.4 & 4.9 \\
\hline$>70 \mathrm{rkm}$ & MAFU & Malus fusca & Pacific crab apple & FACW & Tree & yes & - & 98 & 98 & 1.8 & 3.1 \\
\hline$>70 \mathrm{rkm}$ & POBA & Populus balsamifera & black cottonwood & FAC & Tree & yes & - & 98 & 141 & 1.8 & 4.7 \\
\hline
\end{tabular}




\subsubsection{Distribution of the Most Frequently Present Plant Species}

In the analysis of plant communities, presence/absence data provide a useful alternative perspective to augment the analysis of abundance. Plant species that are among the most abundant plants (See "Distribution of the Most Abundant Plant Species") as well as the most frequent plants, and that were observed at a minimum of one elevation or site and a minimum of two EM zones, are listed in (Table 2.11). Plant species not among the most abundant plants in the LCRE, but observed at a minimum of one elevation or site and a minimum of two EM zones, are termed "Minor Plants" (Table 2.12). Minor plants, although not abundant, may have high ecological value.

Herbaceous plant species that were observed at more than one elevation or site and in a minimum of four EM zones of the river were included in the analysis of presence/absence in emergent marshes, whether they were among the most abundant plants or not. The elevation minimum and maximum at which the most frequently present herbaceous plant species occur can be visualized by river kilometer for marshes (Figure 2.5a) and all other wetland types (Figure 2.5b). The step plots show the minimum and maximum elevation at which the plant was observed, regardless of abundance. These plots and Table 2.11 and Table 2.12 are presented in order according to the number of zones and wetland types in which each plant species was present. It should be noted that while we typically captured the minimum elevation of each plant species because our sampling area typically began at a channel, upper elevations of the distribution were not always observed. As an example of the utility of presence/absence data, Myosotis spp. (MYSP) were widely present in all five EM zones (Figure 2.5a) but only met the abundance criteria for analysis in main-stem marshes in EM2 and EM5 (Table 2.5.). Another example is Impatiens spp. (IMSP), which occurs in all wetland types and all zones of the LCRE (Figure 2.5a, b).

\subsubsection{Non-Native Plant Species}

The average non-native cover increased significantly (regression: $\mathrm{n}=36 ; \mathrm{p}<0.001$ ) between rkm 0 and rkm $60(95 \% \mathrm{CI}=41-81 \mathrm{rkm})$ (Figure 2.6a), and was consistent landward of rkm 60. The proportion of herbaceous plant species cover that is made up of non-natives is highest at $50 \%$ in deciduous forested wetlands (range $39 \%-62 \%$; Figure $2.6 \mathrm{~b})$, followed by $36 \%$ in main-stem marshes $(95 \% \mathrm{CI}=31-40 \%$; Figure 2.7). The proportion is substantially lower at tributary sites, evergreen forested wetlands, and shrub wetlands. However, the much larger sample size of marshes should be taken into account when interpreting these results, because it gives greater confidence than we have for other wetland types in the LCRE. 
PHAR

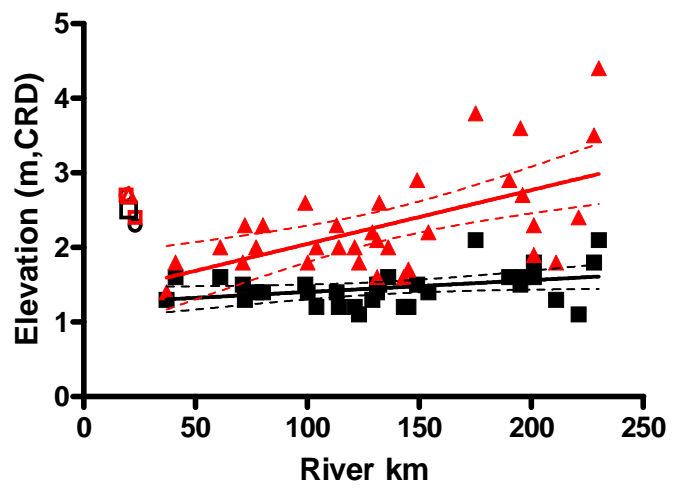

SALA

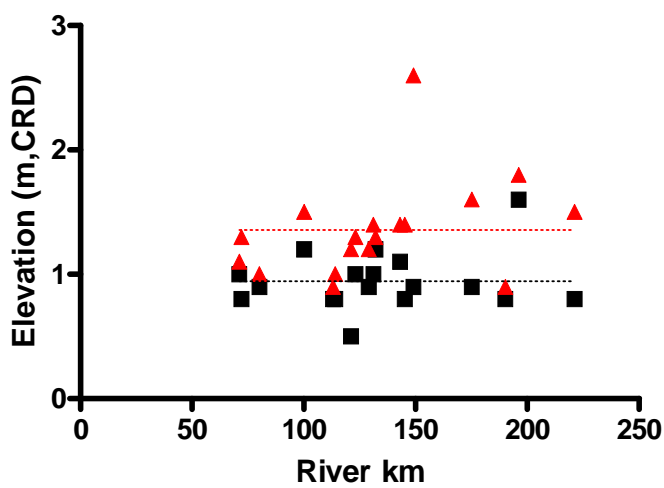

CALY

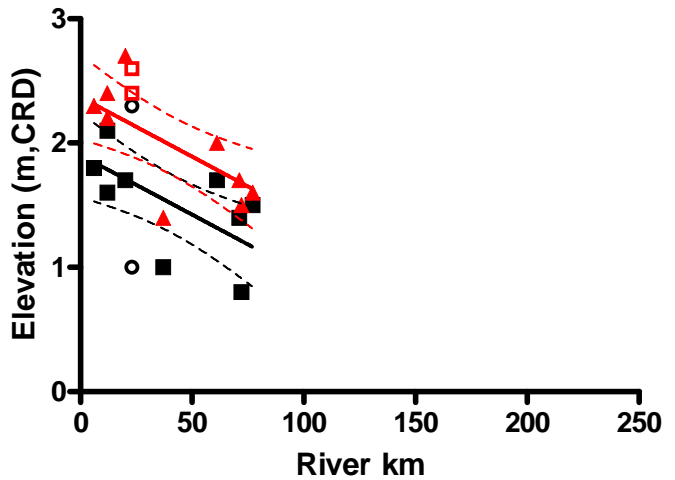

ELPA

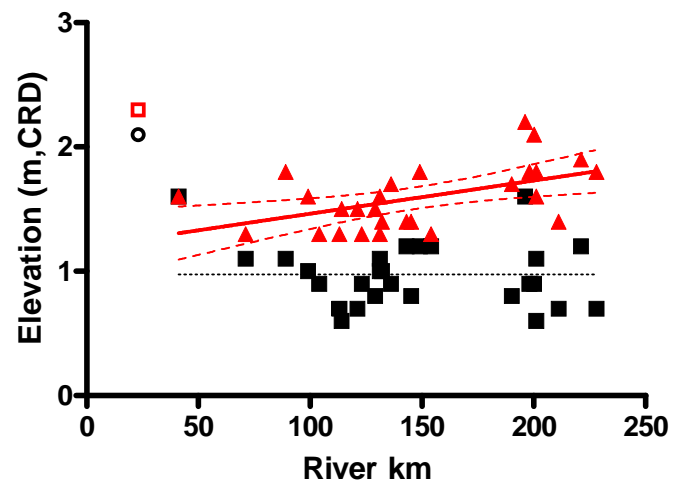

САOB

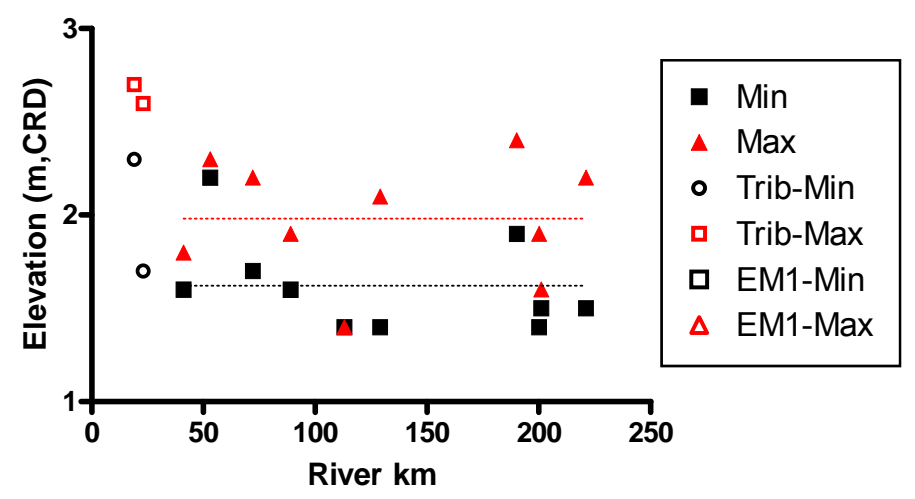

ELCA

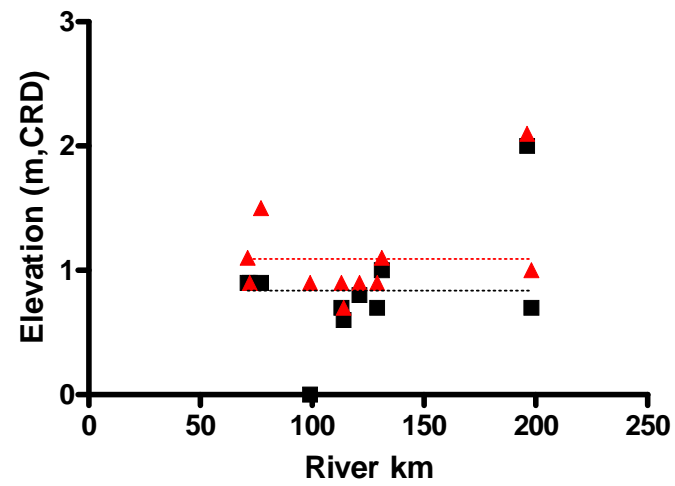

Figure 2.4. The range of elevation of major plants with increasing distance from the Columbia River mouth. Tributary sites were analyzed separately (Trib) and the elevations are relative to NAVD88. Dotted lines parallel to the $\mathrm{x}$-axis represent slopes that are not significantly different from zero, while solid lines with a dashed $95 \%$ confidence interval indicate significant slopes. Sites affected by salinity were not included in the regressions (minimum and maximum) of PHAR. 
Table 2.11. Plant species that are among the most abundant plants and the most frequent plants. These species were observed at a minimum of one elevation or site and were present in marshes in more than one river section (of 6, including 5 EM zones and tributaries). NA = not observed at a measured elevation in the EM zone.

\begin{tabular}{|c|c|c|c|c|c|c|c|c|c|c|c|}
\hline & & & $\begin{array}{c}\text { Count } \\
\text { NA }\end{array}$ & Rive & Extent & & Elevation & Xxtent withis & in Marshes & & $\begin{array}{c}\text { Elevation } \\
\text { Extent within } \\
\text { Tributary } \\
\text { Marsh }\end{array}$ \\
\hline $\begin{array}{l}\text { Plant } \\
\text { Code }\end{array}$ & Scientific Name & Common Name & $\begin{array}{l}\text { No. of } \\
\text { regions } \\
\text { present }\end{array}$ & Marsh & $\begin{array}{l}\text { Tributary } \\
\text { Marsh }\end{array}$ & $\begin{array}{l}\mathrm{Rkm} \\
6-20 \\
\end{array}$ & $\begin{array}{c}\mathrm{Rkm} \\
37-80 \\
\end{array}$ & $\begin{array}{c}\text { Rkm 89- } \\
132 \\
\end{array}$ & $\begin{array}{c}\text { Rkm 136- } \\
175 \\
\end{array}$ & $\begin{array}{c}\text { Rkm 190- } \\
230\end{array}$ & $\begin{array}{c}\mathrm{Rkm} \\
19-23 \\
\end{array}$ \\
\hline$\overline{\mathrm{CAHE}}$ & Callitriche heterophylla & Water starwort & 6 & $20-221$ & $19-23$ & $1.9-2.2$ & $0.8-2.1$ & $0.6-1.8$ & $0.9-2.1$ & $1.8-2.4$ & $-0.2-2.4$ \\
\hline ELPA & Eleocharis palustris & Common spikerush & 6 & $20-228$ & $19-23$ & 2.1 & $0.8-2.4$ & $0.6-2.4$ & $0.8-2.7$ & $0.6-2.6$ & $0.9-2.7$ \\
\hline IMSP & $\begin{array}{l}\text { Impatiens capensis,Impatiens } \\
\text { noli-tangere }\end{array}$ & $\begin{array}{l}\text { Spotted touch-me-not, } \\
\text { Common touch-me-not }\end{array}$ & 6 & $20-190$ & 23 & 2.7 & $1.7-2.4$ & $1.5-2.4$ & 1.3 & $2.2-2.9$ & $0.3-2.7$ \\
\hline MYSP & Myosotis laxa, M. scorpioides & $\begin{array}{l}\text { Small forget-me-not, } \\
\text { Common forget-me-not }\end{array}$ & 6 & $12-201$ & 19 & 1.6 & $0.8-2.2$ & $0.6-2.0$ & 1.2 & $0.6-1.6$ & $0.8-0.9$ \\
\hline PHAR & Phalaris arundinacea & Reed canarygrass & 6 & $20-230$ & $19-23$ & $2.1-2.7$ & $0.8-2.4$ & $0.9-3.5$ & $1.0-3.8$ & $0.8-4.4$ & $0.3-2.7$ \\
\hline POAN & $\begin{array}{l}\text { Potentilla anserina ssp. } \\
\text { Pacifica/Argentina egedii ssp. } \\
\text { Egedii }\end{array}$ & Pacific silverweed & 6 & $6-221$ & $19-23$ & $1.6-2.7$ & $0.8-2.4$ & $1.5-2.3$ & $1.5-2.0$ & $1.2-2$ & $0.3-2.7$ \\
\hline SCTA & Schoenoplectus tabernaemontani & Softstem bulrush, Tule & 6 & $20-221$ & 23 & $1.7-2.7$ & $0.9-2.3$ & $0.5-1.6$ & $1.1-1.6$ & $0.7-1.9$ & $1.3-2.8$ \\
\hline CAOB & Carex obnupta & Slough sedge & 5 & $41-221$ & $19-23$ & NA & $1.6-2.4$ & $1.3-2.4$ & $1.4-2.7$ & $1.1-2.4$ & $1.7-2.7$ \\
\hline EQSP & Equisetum spp. & Horsetail & 5 & $37-230$ & 23 & NA & $1.3-2.1$ & $1-3.5$ & $1-2.7$ & $0.8-3.5$ & 2.4 \\
\hline IRPS & Iris pseudacorus & Yellow iris & 5 & $12-149$ & 23 & $2.3-2.7$ & $1.3-2.4$ & $1.1-2.2$ & $1.5-2.0$ & NA & 2.5 \\
\hline LIOC & Lilaeopsis occidentalis & Western lilaeopsis & 5 & 6-149 & 23 & $1.6-2.3$ & $0.9-1.9$ & $0.7-1.8$ & $0.9-1.6$ & NA & $0.3-2.4$ \\
\hline MEAR & Mentha arvensis & Wild mint & 5 & $61-228$ & 23 & NA & $0.9-2.1$ & $1.3-1.9$ & $1.2-2.3$ & $1.3-2.7$ & $2.4-2.7$ \\
\hline POCR & Potamogeton crispus & Curly leaf pondweed & 5 & $61-201$ & 23 & NA & $0.7-1.7$ & $0-1.2$ & $1.1-1.4$ & $0.6-2.3$ & 2.4 \\
\hline POHY & $\begin{array}{l}\text { Polygonum hydropiper, } P \text {. } \\
\text { hydropiperoides }\end{array}$ & $\begin{array}{l}\text { Waterpepper, Mild } \\
\text { waterpepper, Swamp } \\
\text { smartweed }\end{array}$ & 5 & $37-221$ & 23 & NA & $0.8-2.1$ & $0.9-2.2$ & $1.1-2.5$ & $1.1-2.2$ & $2.3-2.8$ \\
\hline DECE & Deschampsia cespitosa & Tufted hairgrass & 4 & $6-228$ & $19-23$ & $1.6-2.5$ & $0.9-2.0$ & NA & NA & $1.8-3$ & $2.4-2.7$ \\
\hline ELAC & Eleocharis acicularis & Needle spikerush & 5 & $6-221$ & NA & $1.6-2.3$ & $0.8-1.4$ & $0.9-1.7$ & $1.1-1.6$ & $1.2-2.1$ & NA \\
\hline JUBA & Juncus balticus & Baltic rush & 4 & $6-89$ & 23 & $2.0-2.5$ & 1.4 & 1.7 & NA & NA & 1.4 \\
\hline LIAQ & Limosella aquatica & Water mudwort & 4 & $37-221$ & 23 & NA & $0.9-2.0$ & $0.9-1.5$ & NA & $0.6-1.8$ & 2.2 \\
\hline $\mathrm{LOCO}$ & Lotus corniculatus & Birdsfoot trefoil & 4 & 53-149 & 19 & NA & $1.3-2.4$ & $1.5-3.5$ & $1.7-2.8$ & NA & $2.6-2.7$ \\
\hline
\end{tabular}


Table 2.11. (contd)

\begin{tabular}{|c|c|c|c|c|c|c|c|c|c|c|c|}
\hline & & & $\begin{array}{c}\text { Count } \\
\text { NA }\end{array}$ & Rive & Extent & & Elevation & xtent withi & n Marshes & & $\begin{array}{c}\text { Elevation } \\
\text { Extent } \\
\text { within } \\
\text { Tributary } \\
\text { Marsh }\end{array}$ \\
\hline $\begin{array}{l}\text { Plant } \\
\text { Code }\end{array}$ & Scientific Name & Common Name & $\begin{array}{l}\text { No. of } \\
\text { regions } \\
\text { present }\end{array}$ & Marsh & $\begin{array}{l}\text { Tributary } \\
\text { Marsh }\end{array}$ & $\begin{array}{l}\mathrm{Rkm} \\
6-20\end{array}$ & $\begin{array}{c}\mathrm{Rkm} \\
37-80\end{array}$ & $\begin{array}{c}\text { Rkm 89- } \\
132\end{array}$ & $\begin{array}{c}\text { Rkm 136- } \\
175\end{array}$ & $\begin{array}{l}\text { Rkm 190- } \\
230\end{array}$ & $\begin{array}{l}\mathrm{Rkm} \\
19-23\end{array}$ \\
\hline LUPA & Ludwigia palustris & False loosestrife & 5 & $12-221$ & NA & $2.1-2.3$ & $0.8-1.9$ & $0.5-1.9$ & $0.9-2.1$ & $0.6-3.3$ & NA \\
\hline ALTR & Alisma triviale & $\begin{array}{l}\text { Northern water } \\
\text { plaintain }\end{array}$ & 4 & $37-201$ & NA & NA & $0.9-2.1$ & $1-1.8$ & $0.8-1.7$ & $1.5-1.9$ & NA \\
\hline CACA & Calamagrostis canadensis & Bluejoint & 3 & $6-53$ & 23 & $1.6-2.5$ & $2.2-2.4$ & NA & NA & NA & $2.4-2.5$ \\
\hline CALY & Carex lyngbyei & Lyngby sedge & 3 & $6-77$ & 23 & $1.6-2.7$ & $0.8-2.3$ & NA & NA & NA & $0.3-2.7$ \\
\hline CASP & Carex sp. & Carex & 4 & $20-228$ & NA & $2.6-2.7$ & NA & $1.5-2.2$ & $1-2.8$ & $0.8-2.8$ & NA \\
\hline CEDE & Ceratophyllum demersum & Coontail & 4 & $71-201$ & NA & NA & 1.0 & $0.2-1.4$ & 1.2 & $0.2-2.3$ & NA \\
\hline COSE1 & Convolvulus sepium & Hedge bindweed & 4 & $37-230$ & NA & NA & $1.9-2.0$ & 2.4 & $1.4-1.7$ & $1.3-4.4$ & NA \\
\hline ELCA & Elodea canadensis & Canada waterweed & 4 & $61-201$ & NA & NA & $0.8-1.8$ & $-0.1-1.6$ & $0.9-1.7$ & $0.6-2.4$ & NA \\
\hline ELPAR & Eleocharis parvula & Dwarf spikerush & 4 & $6-196$ & NA & $1.7-2.2$ & $0.9-1.2$ & NA & $0.9-1.1$ & $2.2-2.3$ & NA \\
\hline EQFL & Equisetum fluviatile & Water horsetail & 4 & $37-201$ & NA & NA & $0.8-2.2$ & $0.6-2$ & $0.9-2.5$ & $1.5-2.7$ & NA \\
\hline JUOX & Juncus oxymeris & Pointed rush & 4 & $41-201$ & NA & NA & $1.3-2.1$ & $0.9-2$ & $1-1.9$ & $1.2-1.8$ & NA \\
\hline LEOR & Leersia oryzoides & Rice cutgrass & 4 & $41-221$ & NA & NA & $1.6-2.4$ & $0.7-2.0$ & $1.1-1.8$ & $1.3-2.5$ & NA \\
\hline MESP & Mentha spp. & $\begin{array}{l}\text { Mint (field mint, } \\
\text { spearmint) }\end{array}$ & 4 & $37-221$ & NA & NA & $1.8-2.4$ & $1.2-1.3$ & 1.3 & 1.7 & NA \\
\hline MYSP2 & Myriophyllum spp. & Milfoil & 3 & $61-131$ & 23 & NA & $0.7-0.9$ & $0.5-1.7$ & NA & NA & $-0.4-2.2$ \\
\hline MYSP3 & Myriophyllum spicatum & Eurasian water milfoil & 4 & $72-201$ & NA & NA & 0.9 & $0.7-2.1$ & 1.8 & $0.6-0.8$ & NA \\
\hline OESA & Oenanthe sarmentosa & Water parsley & 3 & $20-77$ & $19-23$ & $2.1-2.7$ & $0.8-2.4$ & NA & NA & NA & $2.2-2.7$ \\
\hline POPE & Polygonum persicaria & Spotted ladysthumb & 4 & $37-221$ & NA & NA & $0.8-1.9$ & $0.9-1.8$ & $0.9-2.2$ & $0.7-2$ & NA \\
\hline SALA & Sagittaria latifolia & Wapato & 4 & $37-221$ & NA & NA & $0.8-2.4$ & $0.5-1.9$ & $0.8-2.6$ & $0.6-2.3$ & NA \\
\hline SCAM & Schoenoplectus americanus & $\begin{array}{l}\text { American bulrush, } \\
\text { Threesquare bulrush }\end{array}$ & 4 & $6-149$ & NA & $1.6-2.3$ & $0.8-2$ & $0.6-1.9$ & 1.4 & NA & NA \\
\hline SPAN & Sparganium angustifolium & Narrowleaf burreed & 4 & $37-196$ & NA & NA & $0.9-1.9$ & 1.1 & $0.9-1.6$ & $1.3-2.2$ & NA \\
\hline TYLA & Typha latifolia & Common cattail & 3 & $20-100$ & 23 & $1.7-2.7$ & NA & $1.4-1.9$ & NA & NA & $1.7-2.8$ \\
\hline TYSP & Typha angustifolia, T. latifolia & $\begin{array}{l}\text { Narrowleaf cattail, } \\
\text { Common cattail }\end{array}$ & 3 & $12-53$ & $19-23$ & $2.2-2.7$ & $2.0-2.4$ & NA & NA & NA & $2.2-2.7$ \\
\hline VEAM & Veronica americana & American speedwell & 4 & $37-201$ & NA & NA & $0.9-2.3$ & $0.8-2.3$ & $1-2$ & $1.2-2.3$ & NA \\
\hline BESY & Beckmannia syzigachne & American sloughgrass & 3 & $61-198$ & NA & NA & 1.9 & $1.4-1.6$ & NA & $1-2.3$ & NA \\
\hline EQPA & Equisetum palustre & Marsh horsetail & 3 & $114-221$ & NA & NA & NA & $0.9-2.6$ & $1.2-1.9$ & $1.2-2.3$ & NA \\
\hline
\end{tabular}


Table 2.11. (contd)

\begin{tabular}{|c|c|c|c|c|c|c|c|c|c|c|c|}
\hline & & & $\begin{array}{c}\text { Count } \\
\text { NA }\end{array}$ & Rive & Extent & & Elevation & xtent withi & n Marshes & & $\begin{array}{c}\text { Elevation } \\
\text { Extent } \\
\text { within } \\
\text { Tributary } \\
\text { Marsh }\end{array}$ \\
\hline $\begin{array}{l}\text { Plant } \\
\text { Code } \\
\end{array}$ & Scientific Name & Common Name & $\begin{array}{l}\text { No. of } \\
\text { regions } \\
\text { present }\end{array}$ & Marsh & $\begin{array}{c}\text { Tributary } \\
\text { Marsh }\end{array}$ & $\begin{array}{l}\mathrm{Rkm} \\
6-20 \\
\end{array}$ & $\begin{array}{c}\mathrm{Rkm} \\
37-80 \\
\end{array}$ & $\begin{array}{c}\text { Rkm 89- } \\
132 \\
\end{array}$ & $\begin{array}{c}\text { Rkm 136- } \\
175 \\
\end{array}$ & $\begin{array}{c}\text { Rkm 190- } \\
230\end{array}$ & $\begin{array}{c}\text { Rkm } \\
19-23 \\
\end{array}$ \\
\hline EUOC & Euthamia occidentalis & Western goldentop & 3 & $129-201$ & NA & NA & NA & $1.5-1.9$ & $1.1-1.4$ & $1.2-3.3$ & NA \\
\hline HEAU & Helenium autumnale & Common sneezeweed & 3 & $113-228$ & NA & NA & NA & $1.3-2.1$ & $1.3-2.1$ & $1.2-2.1$ & NA \\
\hline JUAC & Juncus acuminatus & Tapertip rush & 3 & $104-195$ & NA & NA & NA & $1.1-1.7$ & $1.2-1.3$ & 1.7 & NA \\
\hline LYAM & Lysichiton americanus & Skunk cabbage & 2 & 53 & 23 & NA & $2.2-2.4$ & NA & NA & NA & $2.5-2.7$ \\
\hline LYNU & Lysimachia nummularia $L$. & $\begin{array}{l}\text { Moneywort, Creeping } \\
\text { Jenny }\end{array}$ & 3 & $113-228$ & NA & NA & NA & $1.6-2.6$ & $1.4-2.6$ & 2.3 & NA \\
\hline LYSA & Lythrum salicaria & Purple loosestrife & 3 & $37-175$ & NA & NA & $1.1-2.1$ & $1.2-2.1$ & $1-2$ & NA & NA \\
\hline MYLA & Myosotis laxa & Small forget-me-not & 3 & $37-136$ & NA & NA & $1.8-2.1$ & $1.3-2.2$ & $1.5-1.7$ & NA & NA \\
\hline POZO & Potamogeton zosteriformis & Eelgrass pondweed & 3 & $71-211$ & NA & NA & $0.8-1.0$ & $0.8-1.1$ & NA & $0.7-0.8$ & NA \\
\hline TRSP & $\begin{array}{l}\text { Trifolium pratense, T. repens, } \\
\text { T. dubium }\end{array}$ & $\begin{array}{l}\text { Red clover, White } \\
\text { clover, Small hop-clover }\end{array}$ & 3 & $12-149$ & NA & 2.4 & NA & 2.2 & $2.4-2.7$ & NA & NA \\
\hline TYAN & Typha angustifolia & Narrowleaf cattail & 3 & $6-123$ & NA & $1.6-2.1$ & $1.0-2.2$ & $1.3-1.4$ & NA & NA & NA \\
\hline BICE & Bidens cernua & Nodding beggars-ticks & 2 & $41-114$ & NA & NA & $1.0-1.8$ & $1.1-2.1$ & NA & NA & NA \\
\hline $\mathrm{CACO}$ & Carex comosa & Bearded sedge & 2 & $145-221$ & NA & NA & NA & NA & 1.2 & $1.7-2.1$ & NA \\
\hline GATR2 & Galium triflorum & Fragrant bedstraw & 2 & 61-89 & NA & NA & $1.3-2.3$ & $1.7-2$ & NA & NA & NA \\
\hline JUEN & Juncus ensifolius & Daggerleaf rush & 2 & $41-131$ & NA & NA & $1.6-1.8$ & 1.4 & NA & NA & NA \\
\hline MILE & Mimulus lewisii & $\begin{array}{l}\text { Great purple monkey } \\
\text { flower }\end{array}$ & 2 & $113-136$ & NA & NA & NA & $1.2-1.8$ & $1.1-1.5$ & NA & NA \\
\hline MYSC & Myosotis scorpioides & Common forget-me-not & 2 & $53-113$ & NA & NA & $1.5-2.4$ & $0.9-1.6$ & NA & NA & NA \\
\hline PLLA & $\begin{array}{l}\text { Plantago lanceolata var. } \\
\text { lanceolata }\end{array}$ & Rib plantain & 2 & $149-230$ & NA & NA & NA & NA & $2-2.2$ & $1.4-5.3$ & NA \\
\hline POAM & Polygonum amphibium & $\begin{array}{l}\text { Water ladysthumb, } \\
\text { Water smartweed }\end{array}$ & 2 & $145-221$ & NA & NA & NA & NA & $1.1-2.6$ & $1.5-3.1$ & NA \\
\hline PONA & Potamogeton natans & $\begin{array}{l}\text { Floating-leaved } \\
\text { pondweed }\end{array}$ & 2 & $121-149$ & NA & NA & NA & $0.9-1.4$ & $0.8-1.3$ & NA & NA \\
\hline $\mathrm{ROCO}$ & Rorippa columbiae & Columbian yellowcress & 2 & $129-198$ & NA & NA & NA & $1.3-2.2$ & NA & $1.6-1.9$ & NA \\
\hline VESC & Veronica scutellata & Marsh speedwell & 2 & $104-201$ & NA & NA & NA & 1.1 & NA & $0.7-2.6$ & NA \\
\hline ZAPA & Zannichellia palustris & Horned pondweed & 2 & 6-113 & NA & $1-2.1$ & NA & 0.7 & NA & NA & NA \\
\hline
\end{tabular}


Table 2.12. Minor plants present in marshes in more than one river section (of 6, including 5 EM zones and tributaries). NA = not observed at a measured elevation in the EM zone.

\begin{tabular}{|c|c|c|c|c|c|c|c|c|c|c|c|}
\hline \multirow[b]{2}{*}{$\begin{array}{l}\text { Plant } \\
\text { Code }\end{array}$} & \multirow[b]{2}{*}{ Scientific Name } & \multirow[b]{2}{*}{ Common Name } & \multirow{2}{*}{$\begin{array}{l}\text { No. of } \\
\text { regions } \\
\text { present }\end{array}$} & \multicolumn{2}{|c|}{ River Extent } & \multicolumn{5}{|c|}{ Elevation Extent within Marshes } & \multirow{2}{*}{$\begin{array}{c}\text { Elevation } \\
\text { Extent within } \\
\text { Tributary } \\
\text { Marshes } \\
\text { Rkm } \\
19-23\end{array}$} \\
\hline & & & & Marsh & $\begin{array}{l}\text { Tributary } \\
\text { Marsh }\end{array}$ & $\begin{array}{l}\mathrm{Rkm} \\
6-20\end{array}$ & $\begin{array}{c}\mathrm{Rkm} \\
37-80\end{array}$ & $\begin{array}{c}\mathrm{Rkm} \\
89-132\end{array}$ & $\begin{array}{c}\mathrm{Rkm} \\
136-175\end{array}$ & $\begin{array}{c}\text { Rkm } \\
190-230\end{array}$ & \\
\hline EPCI & Epilobium ciliatum & Willow herb & 5 & $37-228$ & 23 & NA & $0.8-2.4$ & $1.6-3.5$ & $1.3-1.8$ & $1.5-2.3$ & $2.3-2.6$ \\
\hline GATR & $\begin{array}{l}\text { Galium trifidum var. } \\
\text { pacificum }\end{array}$ & Pacific bedstraw & 5 & $20-145$ & $19-23$ & 2.7 & $1.6-2.4$ & $1.5-2.4$ & 1.6 & NA & $2.4-2.7$ \\
\hline RUCR & Rumex crispus & Curly dock & 5 & $20-228$ & 23 & 2.4 & $1.7-2.1$ & NA & $2.3-2.8$ & $1.6-2.3$ & $0.3-2.5$ \\
\hline RUMA & Rumex maritimus & $\begin{array}{l}\text { Golden dock, seaside } \\
\text { dock }\end{array}$ & 5 & $12-149$ & 23 & 1.6 & $0.9-2.0$ & $0.9-2.6$ & $1.2-2.7$ & NA & 2.4 \\
\hline SISU & Sium suave & Hemlock waterparsnip & 4 & $20-113$ & 23 & 2.0 & $1.1-2.1$ & 1.4 & NA & NA & 2.4 \\
\hline SODU & Solanum dulcamara & Bittersweet nightshade & 4 & $20-123$ & $19-23$ & $2.6-2.7$ & $1.7-2.0$ & 1.3 & NA & NA & $2.4-2.7$ \\
\hline ELOV & Eleocharis ovata & Ovoid spikerush & 4 & $12-198$ & NA & 1.7 & NA & $1.4-1.7$ & 1.1 & 1.8 & NA \\
\hline HYSC & Hypericum scouleri & Western St. Johns wort & 3 & $53-99$ & 23 & NA & $1.7-2.4$ & $1.5-3.4$ & NA & NA & $2.5-2.7$ \\
\hline POSP & Polygonum sp. & Knotweed, Smartweed & 4 & $37-228$ & NA & NA & $1.6-2.1$ & 1.8 & $1.9-2.1$ & $1.4-1.8$ & NA \\
\hline SCMI & Scirpus microcarpus & Small-fruited bulrush & 3 & $99-145$ & $19-23$ & NA & NA & $1.4-2.0$ & 1.2 & NA & $2.6-2.8$ \\
\hline SYSU & $\begin{array}{l}\text { Symphyotrichum } \\
\text { subspicatum }\end{array}$ & Douglas aster & 3 & $6-71$ & $19-23$ & $2.4-2.5$ & $1.7-2.0$ & NA & NA & NA & $2.4-2.7$ \\
\hline VIAM & Vicia americana & American vetch & 3 & $20-89$ & $19-23$ & 2.7 & NA & $1.4-2.0$ & NA & NA & $2.4-2.7$ \\
\hline AGST & Agrostis stolonifera L. & Creeping bentgrass & 3 & $72-149$ & NA & NA & $2.0-2.2$ & $1.4-2.0$ & 2.7 & NA & NA \\
\hline CIAR & $\begin{array}{l}\text { Cirsium arvense var. } \\
\text { horridum }\end{array}$ & Canada thistle & 3 & $99-201$ & NA & NA & NA & $1.5-3.2$ & $2.8-3.8$ & $1.6-1.9$ & NA \\
\hline GASP & Galium spp & $\begin{array}{l}\text { Pacific bedstraw; } \\
\text { Cleavers; Small bedstraw }\end{array}$ & 2 & $61-72$ & 23 & NA & $1.8-2.1$ & NA & NA & NA & $2.4-2.7$ \\
\hline GRNE & Gratiola neglecta & American Hedge-hyssop & 3 & $39-200$ & NA & NA & $0.9-1.4$ & $1.4-1.8$ & NA & $0.9-1.9$ & NA \\
\hline LAPA & Lathyrus palustris & Marsh peavine & 2 & 53 & 23 & NA & $2.3-2.4$ & NA & NA & NA & 2.6 \\
\hline LYUN & Lycopus uniflorus & Northern bugleweed & 3 & $53-228$ & NA & NA & 2.2 & 1.5 & NA & $1.9-2.3$ & NA \\
\hline
\end{tabular}


Table 2.12. (contd)

\begin{tabular}{|c|c|c|c|c|c|c|c|c|c|c|c|}
\hline \multirow[b]{2}{*}{ Plant } & \multirow[b]{2}{*}{ Scientific Name } & \multirow[b]{2}{*}{ Common Name } & \multirow{2}{*}{$\begin{array}{l}\text { No. of } \\
\text { regions } \\
\text { present }\end{array}$} & \multicolumn{2}{|c|}{ River Extent } & \multicolumn{5}{|c|}{ Elevation Extent within Marshes } & \multirow{2}{*}{$\begin{array}{c}\text { Elevation } \\
\text { Extent within } \\
\text { Tributary } \\
\text { Marsh }\end{array}$} \\
\hline & & & & Marsh & $\begin{array}{l}\text { Tributary } \\
\text { Marsh }\end{array}$ & $\begin{array}{l}\text { Rkm } \\
6-20\end{array}$ & $\begin{array}{c}\mathrm{Rkm} \\
37-80\end{array}$ & $\begin{array}{c}\mathrm{Rkm} \\
89-132\end{array}$ & $\begin{array}{c}\mathrm{Rkm} \\
136-175\end{array}$ & $\begin{array}{c}\mathrm{Rkm} \\
190-230\end{array}$ & \\
\hline PLMA & Plantago major & Common plantain & 3 & $129-201$ & NA & NA & NA & $1.3-2.4$ & $1.7-2.0$ & 1.8 & NA \\
\hline POLA & $\begin{array}{l}\text { Polygonum } \\
\text { lapathifolium }\end{array}$ & Curly top knotweed & 2 & 198 & 23 & NA & NA & NA & NA & $0.6-0.8$ & $2.4-2.7$ \\
\hline RARE & Ranunculus repens & Creeping buttercup & 3 & $77-149$ & NA & NA & 2.1 & $2.1-2.4$ & $1.6-2.3$ & NA & NA \\
\hline COPA & Comarum palustre & $\begin{array}{l}\text { Purple marshlocks, } \\
\text { Marsh cinquefoil }\end{array}$ & 2 & $77-113$ & NA & NA & $1.4-1.8$ & 1.6 & NA & NA & NA \\
\hline GLGR & Glyceria grandis & American mannagrass & 2 & $6-72$ & NA & 2.4 & $1.1-2.2$ & NA & NA & NA & NA \\
\hline JUEF & Juncus effusus & Soft rush & 2 & $72-99$ & NA & NA & $1.6-2.0$ & 1.4 & NA & NA & NA \\
\hline JUTE & Juncus Tenuis & $\begin{array}{l}\text { Slender rush, Poverty } \\
\text { rush }\end{array}$ & 2 & $149-195$ & NA & NA & NA & NA & 2.0 & 2.0 & NA \\
\hline LEMI & Lemna minor & Duckweed & 2 & $131-149$ & NA & NA & NA & $1-1.3$ & 1.5 & NA & NA \\
\hline LYAM2 & Lycopus americanus & $\begin{array}{l}\text { American water } \\
\text { horehound }\end{array}$ & 2 & $37-129$ & NA & NA & $1.1-2.2$ & $1.2-2.0$ & NA & NA & NA \\
\hline MIGU & Mimulus guttatus & Yellow monkeyflower & 2 & $41-129$ & NA & NA & $1.3-2.3$ & $1.3-2.2$ & NA & NA & NA \\
\hline SCCY & Scirpus cyperinus & Woolly sedge & 2 & $113-136$ & NA & NA & NA & $1.2-1.4$ & $1.2-2$ & NA & NA \\
\hline VESP & Veronica spp. & Speedwell & 2 & $104-201$ & NA & NA & NA & 1.6 & NA & $1.3-1.5$ & NA \\
\hline
\end{tabular}




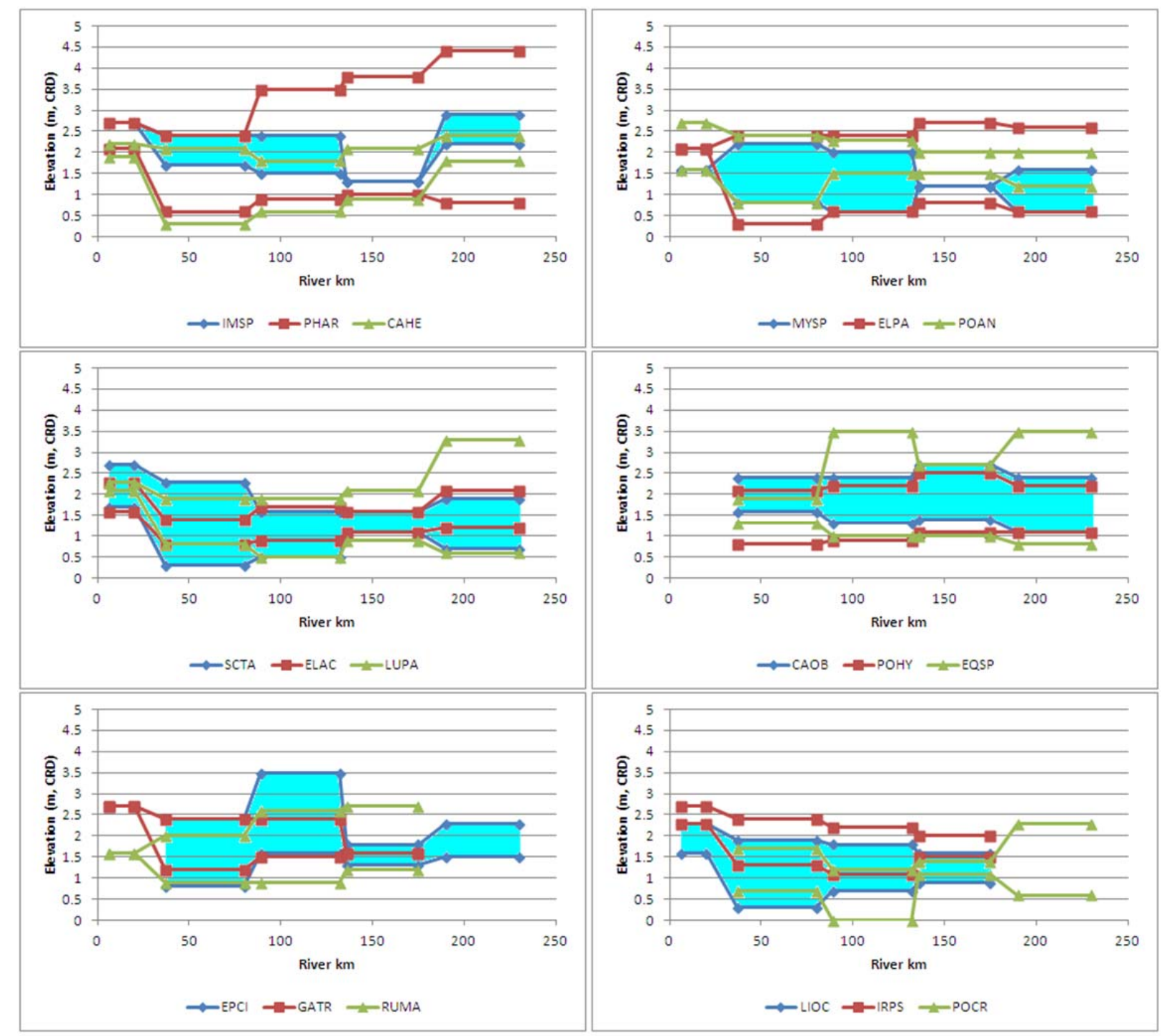

Figure 2.5a. Elevation maximum and minimum of the 36 marsh plants observed in the most environmental conditions, as determined by presence in the largest number of emergent marsh zones and wetland types. Each colored horizontal line segment on a plot represents one of the five emergent marsh (EM) zones, with one exception: EM1 is segmented by the tributary marshes at rkm 23. Connecting lines appear between the most upstream and most downstream sites in adjacent zones. The elevation range of the most frequently present plant species on each plot is highlighted in blue (blue lines for minimum and maximum elevation), for visual reference only. The most frequent three species appear in the top left panel, and frequency decreases in panels to the right and below. The data collection limit was typically at elevations above $3.5 \mathrm{~m}$, CRD; therefore, plots should be interpreted with caution for species with elevations at that level or above. 

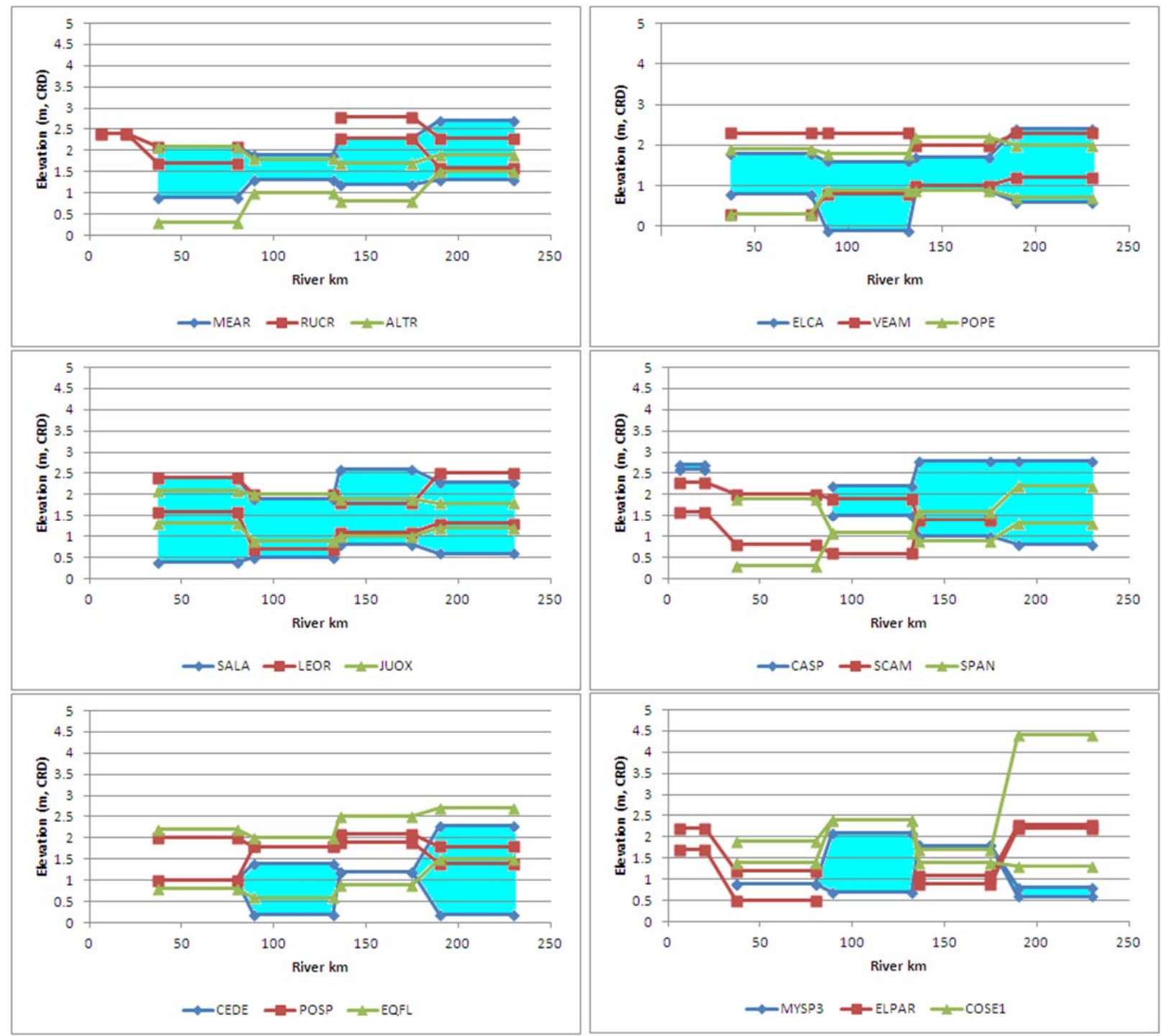

Figure 2.5a. (contd) 

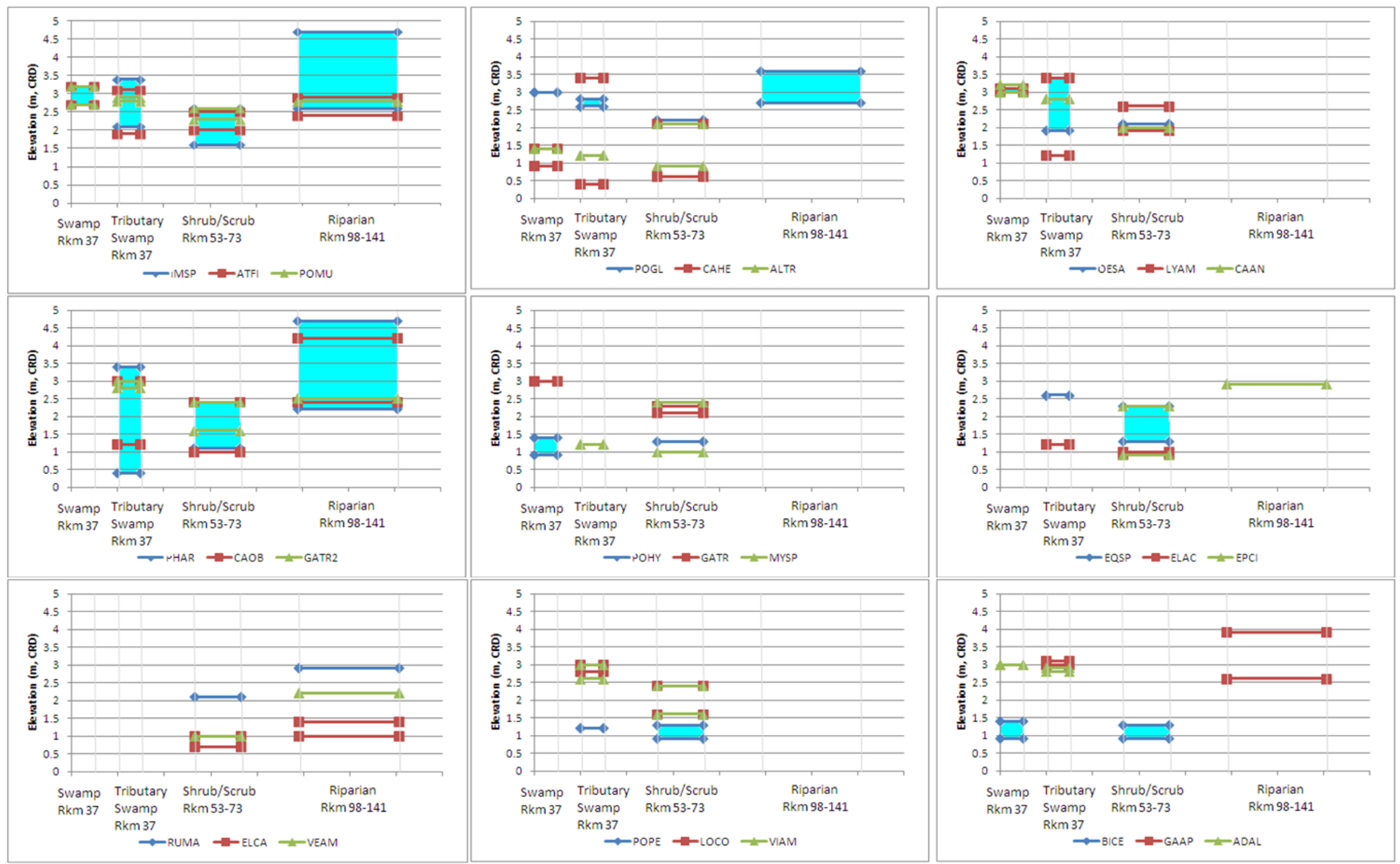

Figure 2.5b. Elevation maximum and minimum of 27 herbaceous plants observed in forested and shrub-dominated wetland types. Plants included were observed in the most environmental conditions, as determined by the largest number of emergent marsh zones and wetland types. Four categories of wetland type and river location are presented in each panel. Note: the number of the sites sampled was smaller than the number of marsh sites, so categories are not connected by lines. The width of the colored line segments for each category reflects the range of river kilometers at which sites were sampled. 


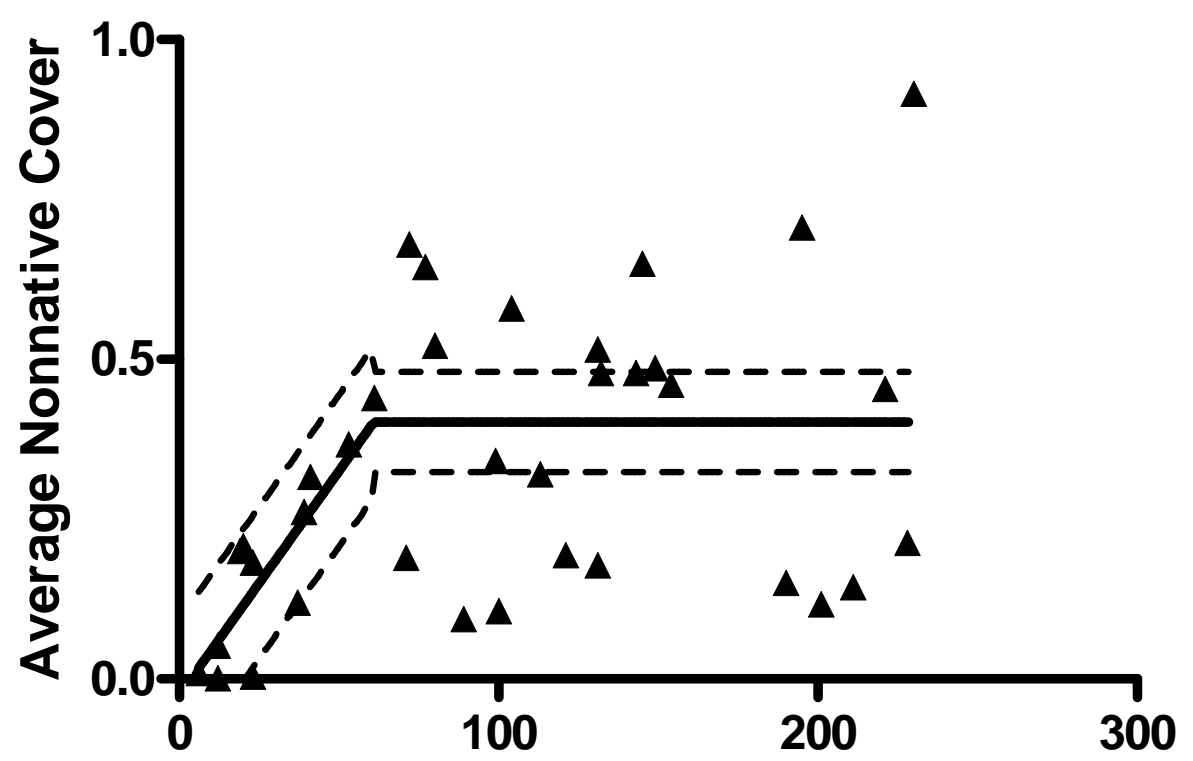

(a)

River km

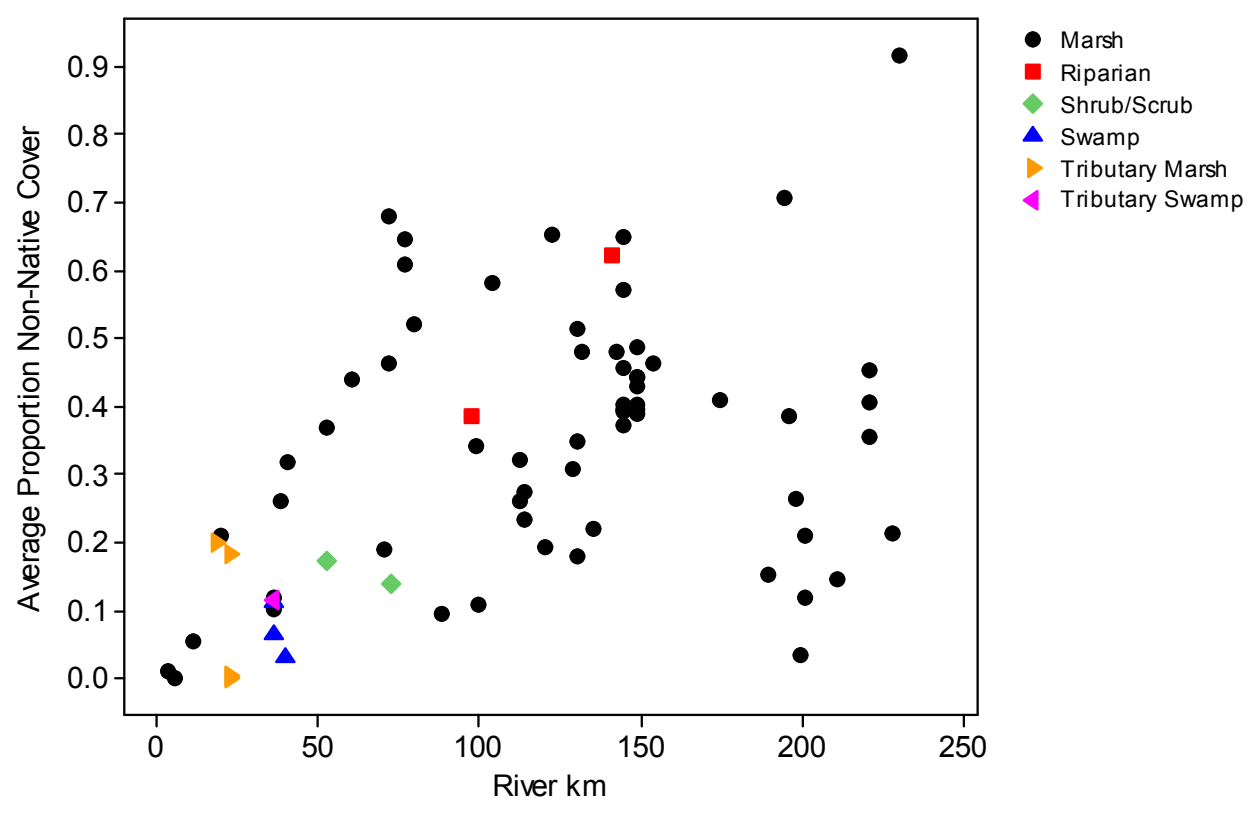

Figure 2.6. (a) Segmented-regression analysis of average non-native herbaceous cover in main-stem marshes by river kilometer. (b) Average proportion of non-native herbaceous cover by river kilometer for all sites and years observed.

Pairwise comparisons of the proportion of non-native cover in wetland types are not significantly different (Tukey's pairwise comparison on ranked data, $\mathrm{p}>0.05$ ). Although tributary marshes apparently have lower non-native cover than main-stem marshes (Figure 2.7), all such sites occurred in EM1 where non-native cover is low (Figure 2.6). Reduced non-native cover in the EM1 zone may be a function of salinity. 


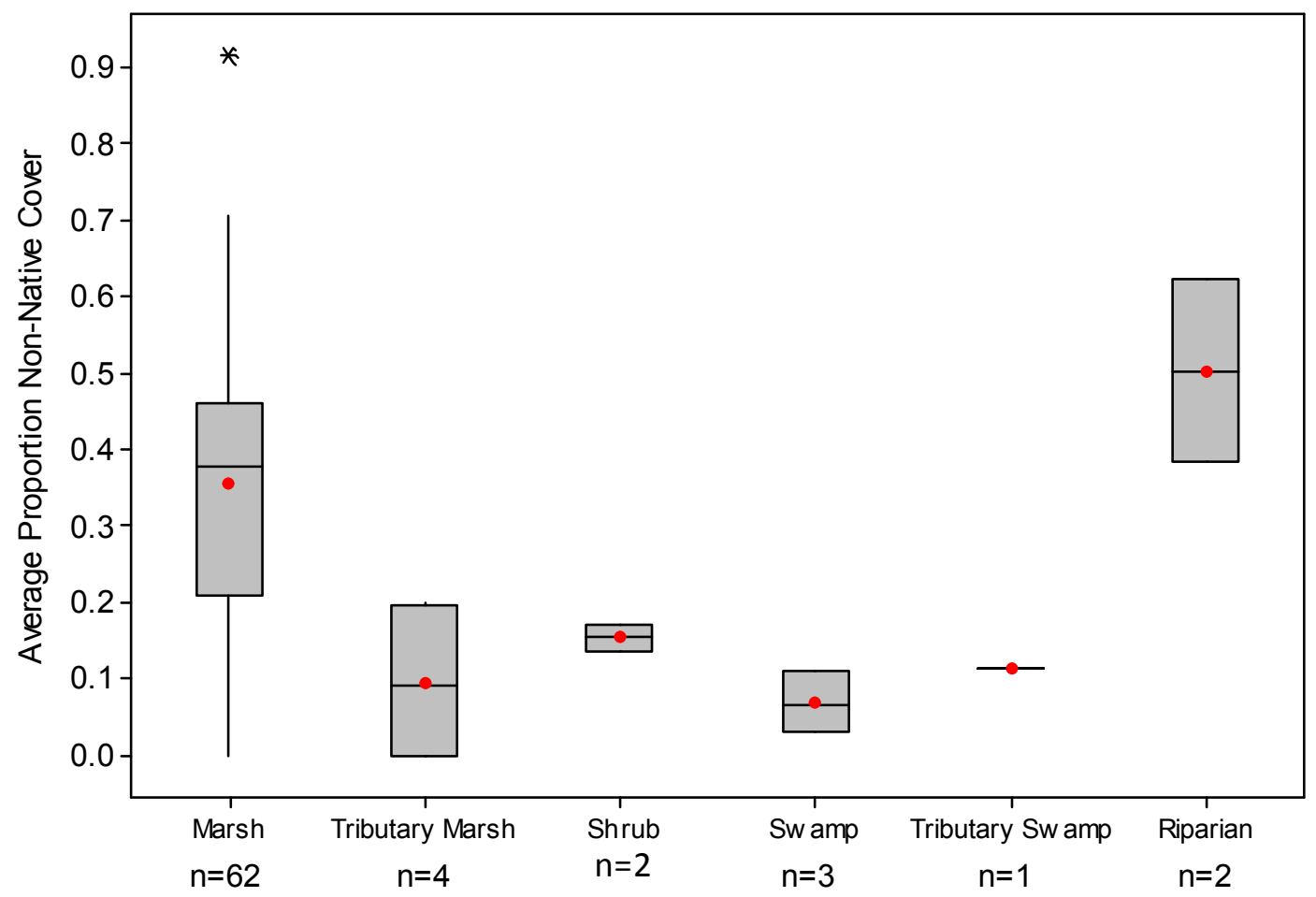

Figure 2.7. Average non-native herbaceous species cover by wetland type, in order from the earliest successional stage at the left.

Reed canarygrass is the most prevalent non-native species in our study area, accounting for approximately $28 \%$ of the total combined native and non-native vegetation cover (Borde et al. 2012b). In all zones, reed canarygrass has a greater probability of occurring at elevations above $1.5 \mathrm{~m}$ than below $1.5 \mathrm{~m}$ (Figure 2.8), except in EM1 where it occurs at higher elevations with a lower probability $(<50 \%)$ of occurrence because of the effects of salinity. The number of sites with reed canarygrass cover of $>20 \%$ is significantly fewer in EM1 and significantly greater in EM5 (Chi-square; $p<0.001$ ). The occurrence of reed canarygrass cover $>20 \%$ was significantly more frequent between elevation of 1.5 to 3 than below 1.5 and above $3 \mathrm{~m}, \mathrm{CRD}(\mathrm{p}<0.001)$, however, the latter result may be influenced by the fact that sampling intensity was lower above $3 \mathrm{~m}, \mathrm{CRD}$.

The average cover of reed canarygrass for a given elevation (nearest tenth $\mathrm{m}, \mathrm{CRD}$ ) within a marsh site (averaged over the sampling years 2005-2011) was calculated $(\mathrm{n}=542$ observations). For those elevations with more than 5 observations ( 0.6 to $2.9 \mathrm{~m}, \mathrm{CRD}$ ), the number of elevations for each zone and elevation range for which the average cover of reed canarygrass was $>20 \%$ was divided by the number of elevations observed so that zones may be compared (Figure 2.9). 


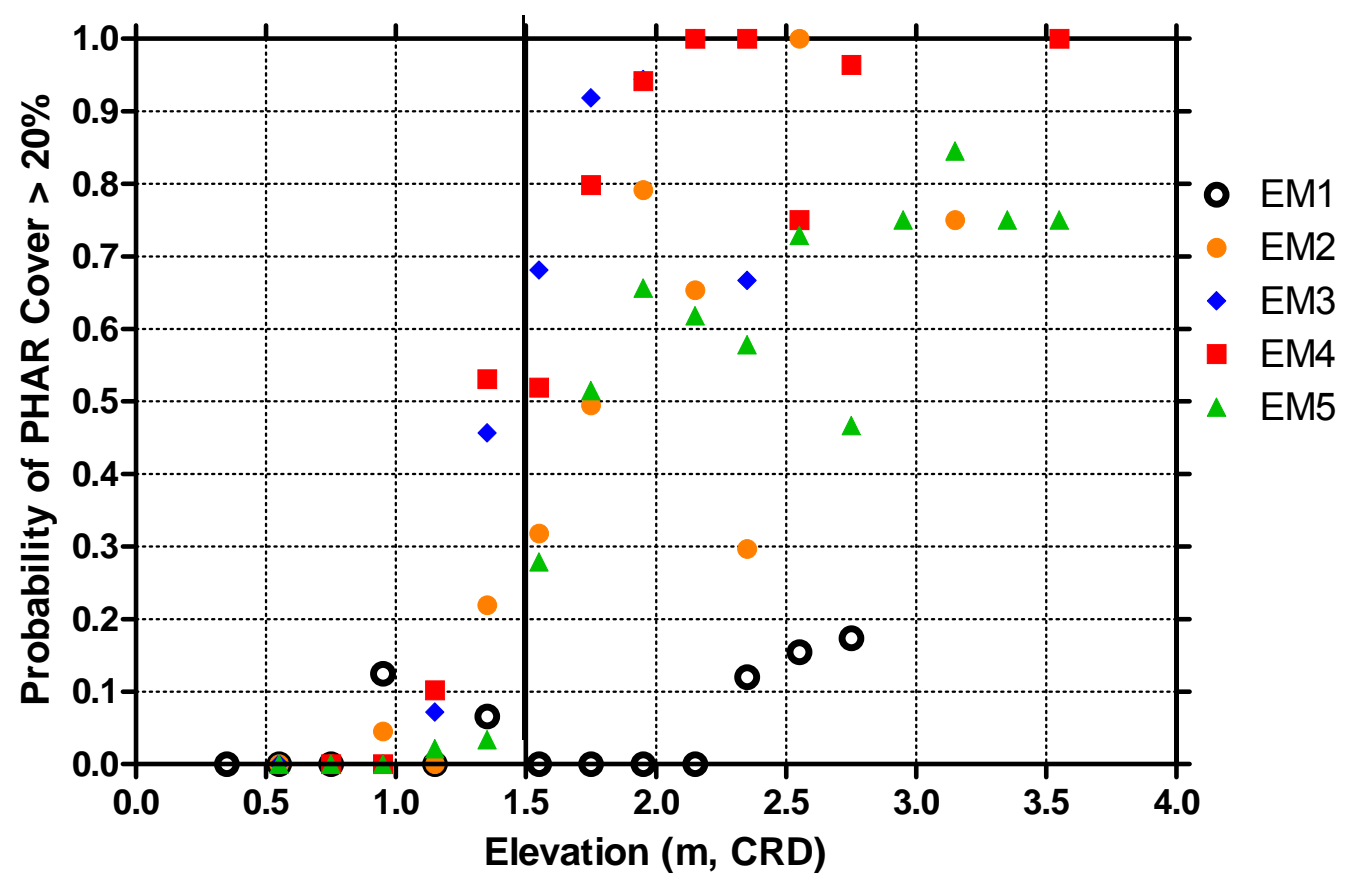

Figure 2.8. Probability of reed canarygrass (PHAR) occurring with an average percent cover of more than $20 \%$ at each elevation. The line drawn at the $1.5 \mathrm{~m}$ elevation designates the elevation where reed canarygrass has $>50 \%$ probability of at least $20 \%$ cover in more than one zone. Data probabilities are averaged, with a moving window average of 2 neighboring elevations.

\subsubsection{Transect Slope}

The average transect slope is an indicator of the overall slope of the wetland. This slope ranged from $0 \%$ to a maximum slope of $14 \%$ (Table 2.13). (For reference, a $45^{\circ}$ angle is associated with a slope equal to $100 \%$, and a $10 \%$ slope is the usual maximum for a driveway.) At our study sites, the average transect slopes were not significantly different between wetland types (Kruskal-Wallis: $n=193 ; p=0.58$ ). Transect slopes were not significantly associated with other metrics describing plant communities or species.

The transect slope varies with the location in the floodplain and along the gradient of the river to some degree, although slope is variable in all locations (Figure 2.10). In general, there is a pattern of increasing slope up the tributaries and up the river. Although slopes do significantly increase with river kilometer on main-stem marshes (regression: $n=174 ; \mathrm{p}<0.001$ ) (Figure 2.10), they are a very poor predictor $\left(\mathrm{R}^{2}=28 \%\right)$. It is possible that the slope is correlated with site area; steeper slope may be indicative of a smaller area. We hypothesize that from a planning perspective, it may be important to keep the slope gradual (maybe $<2 \%$ ) to maximize the wetted area. 


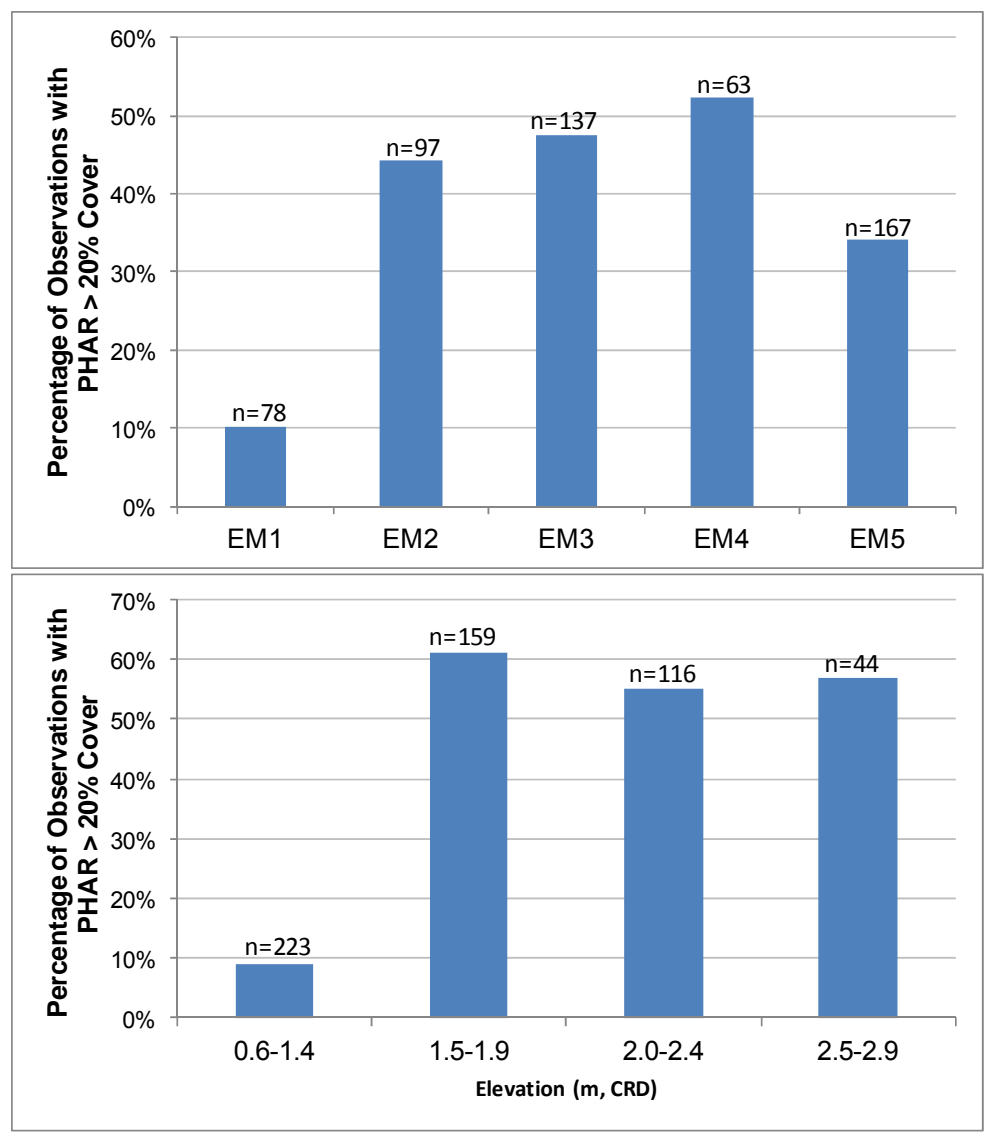

Figure 2.9. Percentage of quadrats in which reed canarygrass (PHAR) occurred at $>20 \%$ cover by emergent marsh (EM) zone (top) and by elevation (bottom).

Table 2.13. Descriptive statistics for the average transect slope ( $n=193$ transects with calculated slope).

\begin{tabular}{|c|c|c|c|c|c|c|c|c|c|}
\hline Wetland type & $\mathrm{N}$ & Mean & $\begin{array}{l}\text { Standard } \\
\text { Deviation }\end{array}$ & Minimum & First Quartile & Median & Third Quartile & Maximum & $\mathrm{CV}$ \\
\hline Marsh & 161 & 0.02 & 0.02 & 0.00 & 0.00 & 0.01 & 0.02 & 0.10 & $114 \%$ \\
\hline Tributary Marsh & 15 & 0.03 & 0.04 & 0.00 & 0.00 & 0.01 & 0.05 & 0.14 & $147 \%$ \\
\hline Riparian & 6 & 0.01 & 0.02 & 0.00 & 0.00 & 0.01 & 0.02 & 0.05 & $160 \%$ \\
\hline Shrub & 6 & 0.01 & 0.01 & 0.00 & 0.00 & 0.01 & 0.02 & 0.02 & $71 \%$ \\
\hline Swamp & 1 & 0.00 & (a) & 0.00 & (a) & 0.00 & (a) & 0.00 & NA \\
\hline Tributary Swamp & 4 & 0.02 & 0.03 & 0.00 & 0.00 & 0.01 & 0.05 & 0.07 & $131 \%$ \\
\hline
\end{tabular}

(a) quartiles (Q1 and Q3) cannot be calculated for sample sizes less than 3

$\mathrm{NA}=$ analysis not appropriate for sample sizes less than 3 

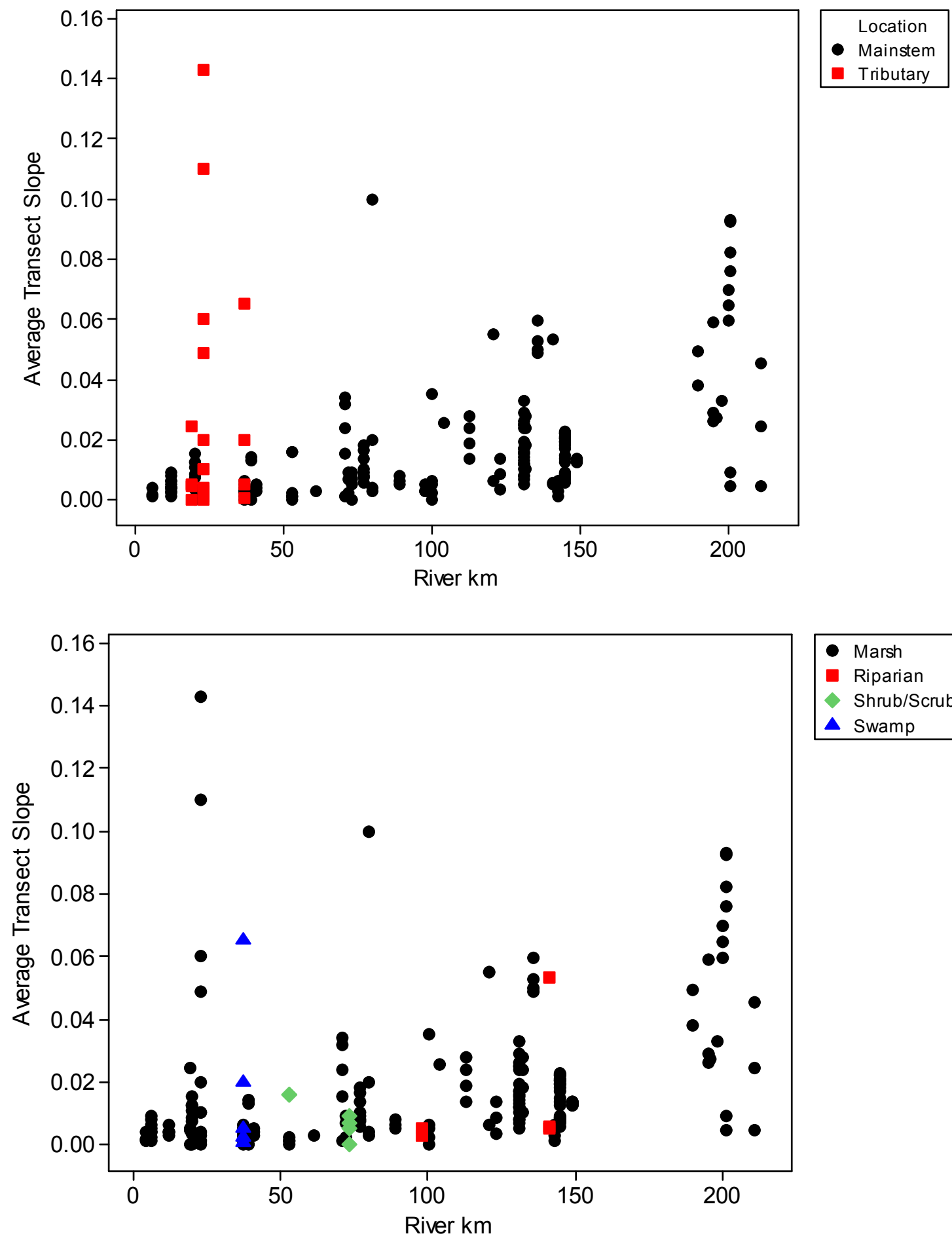

$\begin{array}{ll}\text { - } & \text { Marsh } \\ \text { - Riparian } \\ \text { Shrub/Scrub } \\ \text { - Swamp }\end{array}$

Figure 2.10. Average transect slope (percent) for study sites differentiated by location on the main-stem or a tributary (top panel) and by wetland type (bottom panel). 


\subsubsection{Tidal Wetland Processes}

\subsubsection{Spatial Distribution of the Hydrologic Regime}

To assess hydrologic patterns and compare sites, we used a single measurement that incorporates magnitude, timing, and duration of surface water flooding. Following work conducted in the United Kingdom and the United States (Simon et al. 1997; Gowing et al. 2002; Araya et al. 2010) we calculated the SEV for the growing season: April 22 to June 21 and August 20 to October 12 (115 days) (see Statistical Methods). The SEV increases significantly (regression: $n=35 ; \mathrm{p}<0.001$ ) with increasing rkm (Figure 2.11) and decreases significantly (regression: $n=35 ; p=0.003$ ) with average wetland elevation (Figure 2.12).

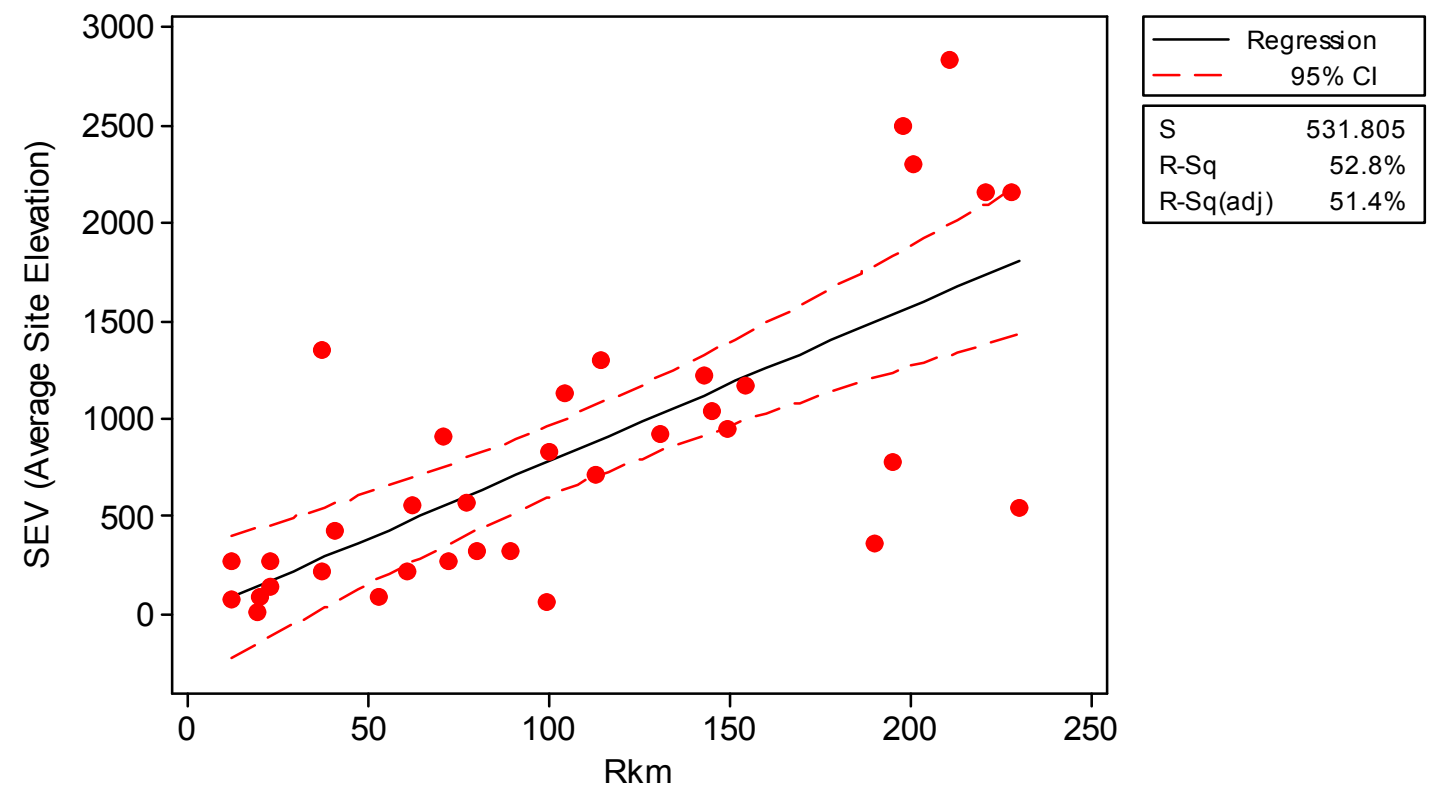

Figure 2.11. Variation in sum exceedance value (SEV) by site river kilometer.

Swamps had significantly smaller SEVs than emergent marshes (Kruskal-Wallis: $n=43 ; \mathrm{p}=0.001$ ). The wide range of SEVs between 1 and $2 \mathrm{~m}$, CRD may be caused by inter-annual variability and location in the estuary (Borde et al. 2012a) (Figure 2.12). Hardy Creek (HC) is an outlier because it is a highelevation site, located near Bonneville Lock and Dam (rkm 230), so it receives an unusually small amount of inundation for that zone.

Our interpretations of the influence of inter-annual variability in river discharge on SEV are based on general assessments of flow levels during the growing season: 2007 (low), 2008 (high), 2009-10 (moderate), and 2011 (very high). (These ranks only compare these years to one another, not to historical conditions.) Sites located in the lower part of the LCRE have low variability in SEV between years, e.g., Whites Island (WHC) in 2010 and 2011 (Figure 2.13a), as expected because the fluvial effect is reduced by the greater width of the floodplain (Jay et al. in review). Sites located further upriver have a greater variability between years; e.g., Campbell Slough (CS1) in 2010 and 2011 (Figure 2.13b). Likewise, at McGuire Island at rkm 190 the similarity in SEV can be observed between 2009 and 2010, however, lower SEV's occurred in 2007 as a result of the lower flows in that year (Figure 2.13c). 


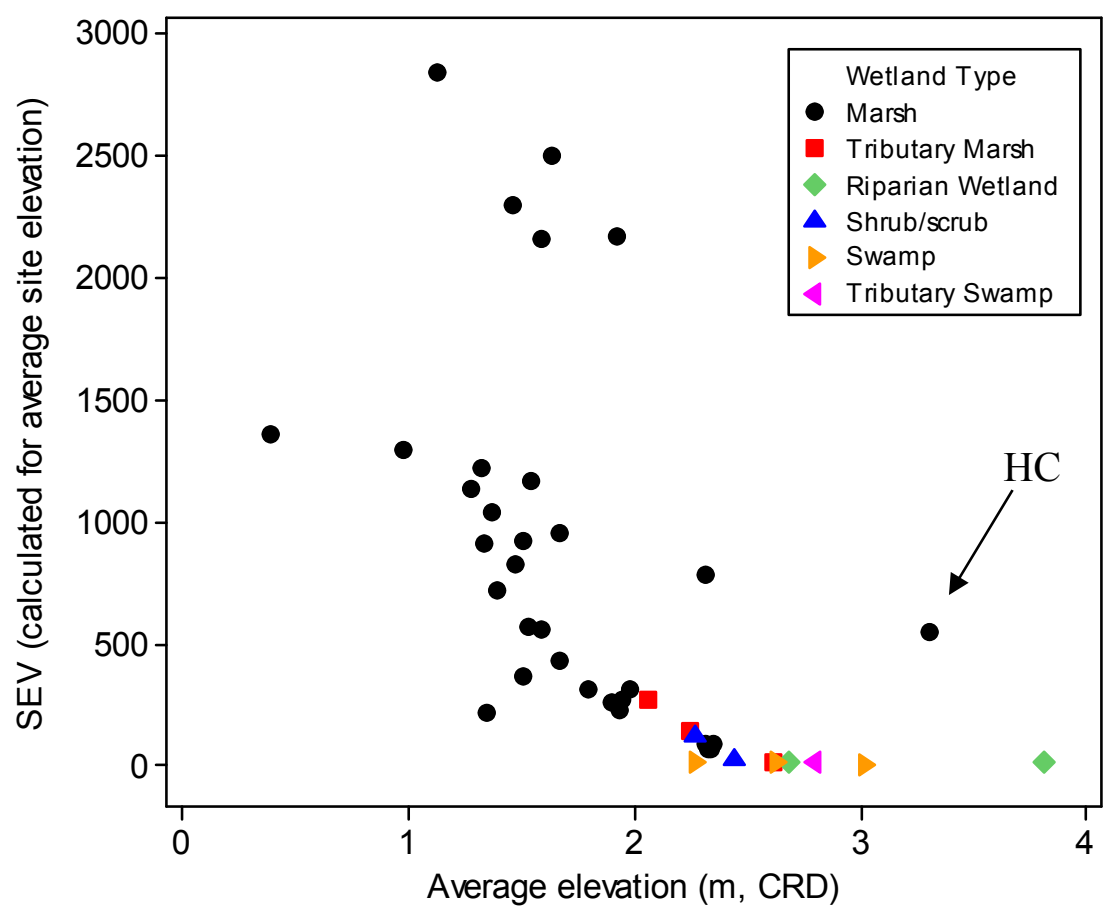

Figure 2.12. Variation in sum exceedance value (SEV) by average site elevation. ( $\mathrm{HC}=$ Hardy Creek)

Variability in SEV can also be affected by hydrologic connectivity as seen in the three sites from similar locations in the river during the same years (Figure $2.13 \mathrm{~d}, \mathrm{e}, \mathrm{f}$ ). The old Sandy River channel marsh (OSR) site (Figure 2.13d) is likely affected during high water years such as 2008 by additional flows from the Sandy River, while it is presumed to be cut-off from Columbia River flows during lower water periods that may have occurred more frequently in 2009. Thus, the difference between the SEV in 2008 and 2009 is greater at this site than at the other two sites. The Chatham Island (CIC) site has slightly lower SEV values than the Reed Island (RIC) site in the lower water year (2009), again because the site is likely disconnected at times of low water from Columbia River flows. The observed minimum and maximum SEV's within EM zones are provided in Table 2.14. 

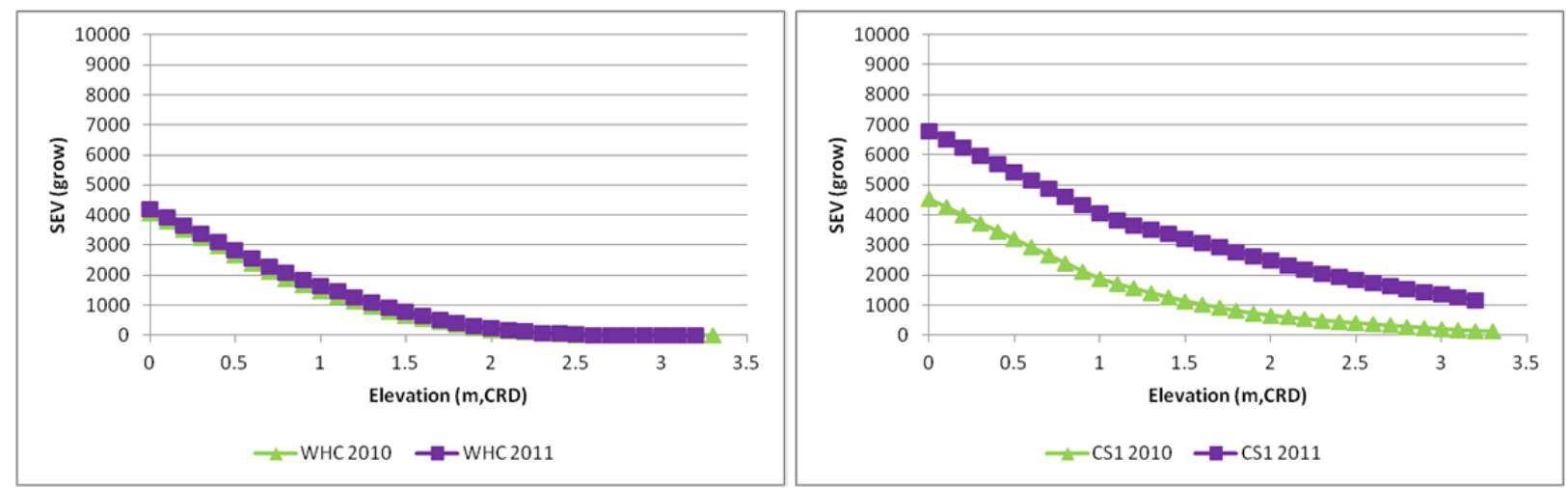

a) Rkm 72 b) Rkm 149
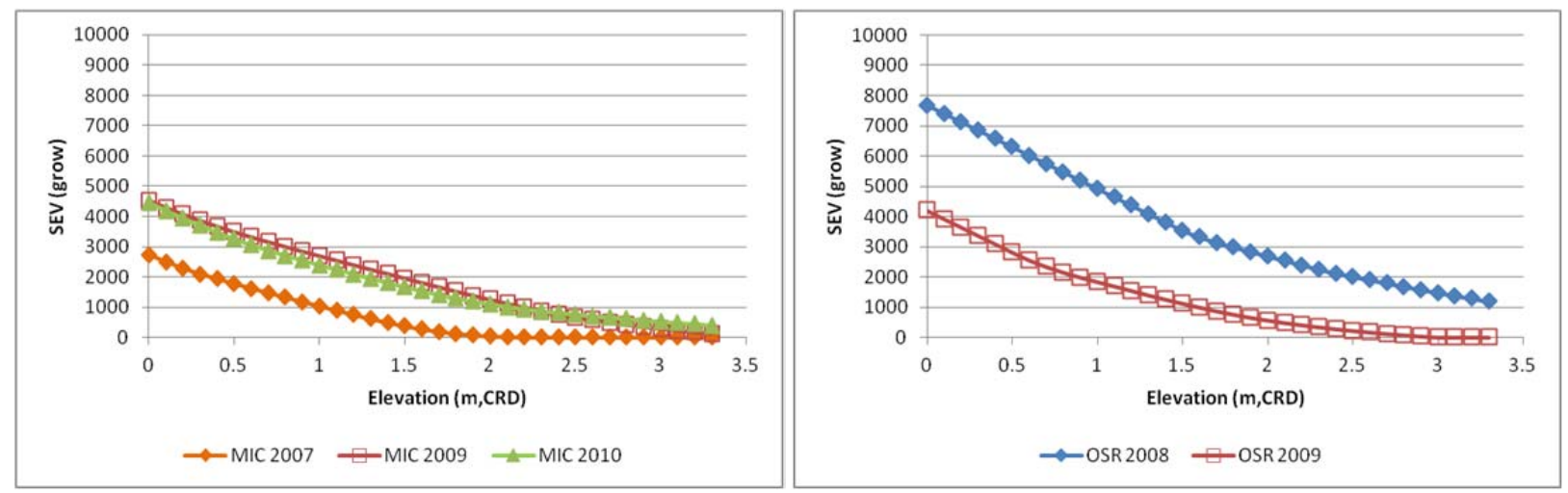

c) Rkm 190 d) Rkm 196
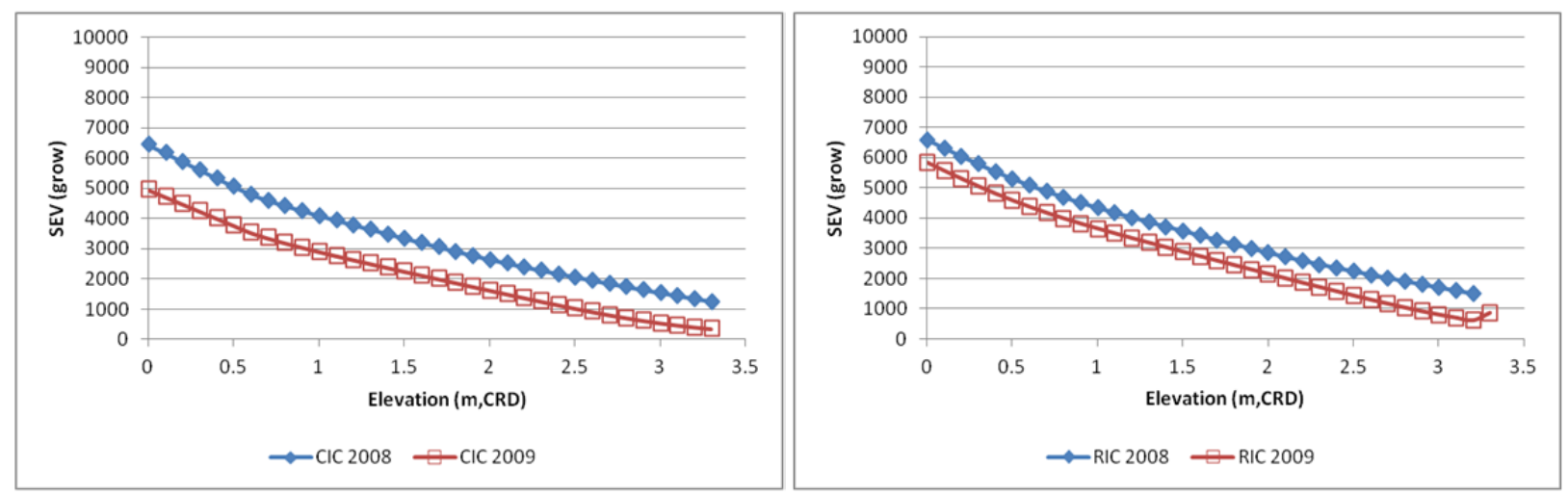

e) Rkm 201 f) Rkm 201

Figure 2.13. Sum exceedance values (SEV) along the elevation gradient, at selected sites from rkm 72 to $\mathrm{rkm}$ 201. Site codes: $\mathrm{WHC}=$ Whites Island, CS1 $=$ Campbell Slough, $\mathrm{MIC}=$ McGuire Island, OSR = Old Sandy River Channel Marsh, CIC $=$ Chatham Island, RIC $=$ Reed Island 
Table 2.14. Observed minimum and maximum of the growing season sum exceedance value (SEV) by wetland type associated with elevations in which major herbaceous plant species occurred. Elevation $\geq 1.5 \mathrm{~m}, \mathrm{CRD}$ is considered high-elevation category. By convention, where data time series records span two years, the year given is that of the spring freshet.

\begin{tabular}{|c|c|c|c|c|c|c|}
\hline Type & $\begin{array}{l}\mathrm{Rkm} \\
6-40 \\
\end{array}$ & $\begin{array}{l}\text { Tributaries } \\
\text { Rkm 6-40 }\end{array}$ & $\begin{array}{c}\mathrm{Rkm} \\
40-100\end{array}$ & $\begin{array}{c}\mathrm{Rkm} \\
100-136\end{array}$ & $\begin{array}{c}\mathrm{Rkm} \\
136-181\end{array}$ & $\begin{array}{c}\mathrm{Rkm} \\
181-230\end{array}$ \\
\hline $\begin{array}{c}\text { Swamp } \\
(\text { all }>1.5 \mathrm{~m})\end{array}$ & $\begin{array}{l}0-1.7 \\
\mathrm{n}=1 \\
2008\end{array}$ & $\begin{array}{c}0-440 \\
n=1 \\
2009\end{array}$ & - & - & - & - \\
\hline $\begin{array}{l}\text { Riparian Wetland } \\
\quad(\text { all }>1.5)\end{array}$ & - & - & $\begin{array}{l}0-55 \\
n=1 \\
2009\end{array}$ & - & $\begin{array}{c}0-523 \\
n=1 \\
2010\end{array}$ & - \\
\hline Low-Elevation Shrub & - & - & $\begin{array}{c}729-2560 \\
n=2 \\
2009-2010\end{array}$ & - & - & - \\
\hline High-Elevation Shrub & - & - & $\begin{array}{c}0-830 \\
n=2 \\
2009-2010\end{array}$ & - & - & - \\
\hline Low-Elevation Marsh & $\begin{array}{c}186-514 \\
n=1 \\
2008\end{array}$ & $\begin{array}{c}930-3126 \\
n=2 \\
2010\end{array}$ & $\begin{array}{c}730-4215 \\
n=7 \\
2008-2011\end{array}$ & $\begin{array}{c}716-2062 \\
n=4 \\
2009-2010\end{array}$ & $\begin{array}{c}1129-3232 \\
n=4 \\
2010-2011\end{array}$ & $\begin{array}{c}2342-4730 \\
n=9 \\
2009-2010\end{array}$ \\
\hline High-Elevation Marsh & $\begin{array}{c}8-620 \\
n=3 \\
2007-2009\end{array}$ & $\begin{array}{c}5-842 \\
n=3 \\
2009-2010\end{array}$ & $\begin{array}{c}0-903 \\
\mathrm{n}=9 \\
2008-2011\end{array}$ & $\begin{array}{c}157-946 \\
\mathrm{n}=4 \\
2009-2010\end{array}$ & $\begin{array}{c}594-2187 \\
n=4 \\
20010-2011\end{array}$ & $\begin{array}{c}306-2093 \\
\mathrm{n}=10 \\
2009-2010\end{array}$ \\
\hline Average Marsh & $\begin{array}{c}68-1357 \\
n=5 \\
2008-2009\end{array}$ & $\begin{array}{c}10-266 \\
n=3 \\
2009\end{array}$ & $\begin{array}{c}64-910 \\
n=9 \\
2008-2010\end{array}$ & $\begin{array}{c}718-1297 \\
\mathrm{n}=5 \\
2009\end{array}$ & $\begin{array}{c}952-1221 \\
n=4 \\
2010\end{array}$ & $\begin{array}{c}360-2844 \\
\mathrm{n}=7 \\
2007-2010\end{array}$ \\
\hline
\end{tabular}

\subsubsection{Sediment Accretion Rate}

Descriptive statistics of accretion or erosion rates were calculated for each wetland type (Table 2.15). Typically, these data were collected for one year at one location in the site. These data are analyzed further in Section 3, to explore the relationships between physical metrics, as well as implications for controlling factors on plant community development.

Table 2.15. Descriptive statistics of sediment accretion rate $(\mathrm{cm} / \mathrm{yr})$ by wetland type and location within sites.

\begin{tabular}{llcccccccc}
\hline \multicolumn{1}{c}{ Variable } & \multicolumn{1}{c}{ Strata } & N & Mean & StDev & Minimum & Q1 & Median & Q3 & Maximum \\
\hline Yearly & Marsh & 38 & 0.49 & 1.92 & -7.76 & 0.00 & 0.50 & 1.61 & 3.69 \\
Accretion/ & Tributary Marsh & 2 & 1.21 & 1.89 & -0.13 & (a) & 1.21 & (a) & 2.55 \\
Erosion & Riparian & 1 & 0.84 & (a) & 0.84 & (a) & 0.84 & (a) & 0.84 \\
(cm/yr) & Swamp & 3 & 0.24 & 0.19 & 0.04 & 0.04 & 0.26 & 0.43 & 0.43 \\
& Tributary Swamp & 1 & 0.38 & (a) & 0.38 & (a) & 0.38 & (a) & 0.38 \\
& Shrub & 2 & 0.93 & 2.67 & -0.96 & (a) & 0.93 & (a) & 2.82 \\
\hline
\end{tabular}

(a) Quartiles (Q1 and Q3) cannot be calculated for sample sizes less than 3.

The sediment accretion rate was not significantly different between wetland types (Kruskal-Wallis test: $\mathrm{n}=47 ; \mathrm{p}=0.98$; Figure 2.14 ). Average sediment accretion rates were nearly significantly different between EM zones (Kruskal-Wallis test: $\mathrm{n}=38, \mathrm{p}=0.054$; Table 2.16). 


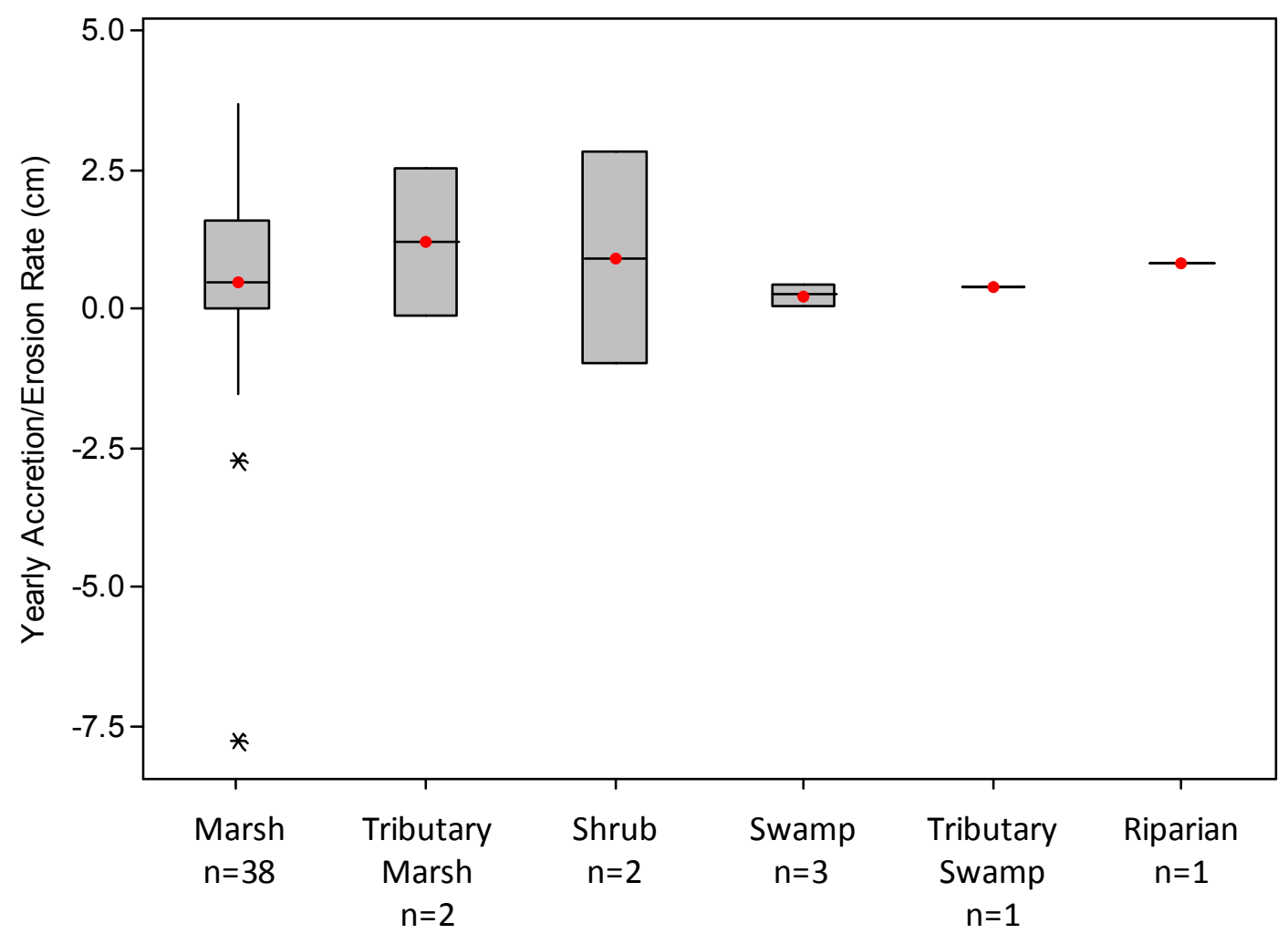

Figure 2.14. Yearly sediment accretion/erosion rate at six wetland types.

Table 2.16. Average sediment accretion rates $(\mathrm{cm} / \mathrm{yr})$ by EM zone for emergent main-stem marshes.

\begin{tabular}{ccccccccc}
\hline Zone & $\mathrm{N}$ & Mean & StDev & Minimum & Q1 & Median & Q3 & Maximum \\
\hline EM1 & 8 & 1.0 & 0.9 & -0.2 & 0.3 & 0.8 & 1.6 & 2.8 \\
EM2 & 13 & 0.4 & 1.4 & -1.5 & -0.9 & 0.4 & 1.2 & 3.7 \\
EM3 & 6 & -0.5 & 1.2 & -2.7 & -1.5 & 0.1 & 0.3 & 0.5 \\
EM4 & 5 & 1.6 & 0.8 & 0.4 & 1.0 & 1.7 & 2.2 & 2.5 \\
EM5 & 6 & 0.0 & 4.0 & -7.8 & -2.1 & 1.0 & 3.0 & 3.0 \\
\hline
\end{tabular}

\subsubsection{Tidal Wetland Habitat Functions for Juvenile Salmon}

\subsubsection{Water Temperature}

The 7-day average daily maximum water temperature (7-DADMAX) is a metric used in surface water quality standards for salmon rearing and migration habitats. The median 7-DADMAX water temperature during the spring, early summer, and late summer were calculated from water sensor data (see Statistical Methods). Because many sensors had different lengths of record, the longest uninterrupted time periods were chosen for analysis so that a maximum number of sensors could be used (Table 2.17.). 
Table 2.17. Median 7-DADMAX water temperature (degrees Celsius $\left[{ }^{\circ} \mathrm{C}\right]$ ) for all wetland types in five zones of the main-stem river and in tributaries to the estuary.

\begin{tabular}{|c|c|c|c|c|c|c|}
\hline Time Period & $\begin{array}{l}\text { Rkm } \\
6-40 \\
\end{array}$ & $\begin{array}{l}\text { Tributaries } \\
\text { Rkm 6-40 }\end{array}$ & $\begin{array}{c}\mathrm{Rkm} \\
40-100\end{array}$ & $\begin{array}{c}\mathrm{Rkm} \\
100-136 \\
\end{array}$ & $\begin{array}{c}\mathrm{Rkm} \\
136-181 \\
\end{array}$ & $\begin{array}{c}\text { Rkm } \\
181-230 \\
\end{array}$ \\
\hline $\begin{array}{c}\text { Median Water } \\
\text { Temperature } \\
3 / 15-5 / 2 \\
2008-10\end{array}$ & $\begin{array}{c}9.7-13.0 \\
n=6\end{array}$ & $\begin{array}{c}11.6-12.5 \\
\mathrm{n}=3\end{array}$ & $\begin{array}{c}9.8-13.6 \\
n=9\end{array}$ & $\begin{array}{c}9.8-13.5 \\
n=5\end{array}$ & $\begin{array}{c}11.7-16.6 \\
n=5\end{array}$ & $\begin{array}{c}8.4-12.4 \\
n=11\end{array}$ \\
\hline $\begin{array}{c}\text { Median Water } \\
\text { Temperature } \\
5 / 3-6 / 20 \\
2008-10\end{array}$ & $\begin{array}{c}15.2-20.0 \\
\mathrm{n}=6\end{array}$ & $\begin{aligned} 15.1 & -18.9 \\
\mathrm{n} & =3\end{aligned}$ & $\begin{aligned} 14.4 & -21.4 \\
\mathrm{n} & =9\end{aligned}$ & $\begin{aligned} 14.7 & -16.5 \\
\mathrm{n} & =5\end{aligned}$ & $\begin{array}{c}15.2-18.7 \\
\mathrm{n}=5\end{array}$ & $\begin{array}{c}12.2-16.0 \\
\mathrm{n}=11\end{array}$ \\
\hline $\begin{array}{c}\text { Median Water } \\
\text { Temperature } \\
8 / 22-10 / 9 \\
2007-09\end{array}$ & $\begin{array}{c}16.9-19.3 \\
\mathrm{n}=8\end{array}$ & $\begin{array}{c}15.8-19.6 \\
n=6\end{array}$ & $\begin{array}{c}19.8-22.3 \\
\mathrm{n}=11\end{array}$ & $\begin{array}{c}21.2-24.3 \\
\mathrm{n}=3\end{array}$ & $\begin{array}{c}22.7-28.5 \\
\mathrm{n}=4\end{array}$ & $\begin{array}{c}13.8-23.0 \\
\mathrm{n}=9\end{array}$ \\
\hline
\end{tabular}

In 2008 and 2009, the freshet caused lower water temperatures during the peak flow period (May to June) (Figure 2.15). In 2009, the warm air temperatures and reservoir temperatures are reflected in elevated late summer water temperatures (August to October). Tributary sites are not used in the regression analyses because of the following observations concerning main-stem river conditions:

- During the March 15 to May 2 time period, a 2008 swamp tributary (rkm 37) result is lower than expected (outside the regression 95\% CI) and very low during the May 3 to June 20 time period.

- During the March 15 to May 2 time period in 2009, the same swamp tributary (rkm 37) result is again lower than expected (outside the regression 95\% CI) and again very low during the May 3 to June 20 time period.

- During the March 15 to May 2 time period, the 2010 tributary data are consistent with the main-stem 2010 data (inside the regression 95\% CI) except for a site at the mouth of the Washougal River at rkm 195 (outside the regression 95\% CI).

- During the March 3 to June 20 time period, the water temperature on the Youngs River (rkm 23) is a little low and Washougal (rkm 195) is very low.

- During the August 22 to October 9 time period, the same swamp tributary (rkm 37) was below the 95\% lower confidence limit for the regression for 2007.

Furthermore, tributary temperatures were not always consistent with each other:

- During the August 22 to October 9 time period in 2008, a site on the Lewis and Clark River (rkm 19) is within the confidence interval, but is not used in the regression. In contrast, temperatures at the swamp tributary site (rkm 37) remained very low.

- In 2009, sites in Youngs River at rkm 23 are within the confidence interval, while Washougal at rkm 195 remains low.

During the March 15 to May 2 time period, only water temperatures in the year 2010 significantly increased with river kilometer (regression: $\mathrm{n}=12 ; \mathrm{p}=0.035$ ). During the May 3 to June 20 time period, temperatures in both 2008 and 2009 significantly decreased with river kilometer (regression: $n>10$; 
$\mathrm{p}<0.02$ ), with no difference in slope. During the August 22 to October 9 time period, 2009 water temperatures significantly increased with river kilometer (regression: $n=11 ; p=0.004$ ). Water temperatures in the upper EM zones appear to be influenced by colder spring runoff, and in the lower EM zones by colder seawater in the late summer.
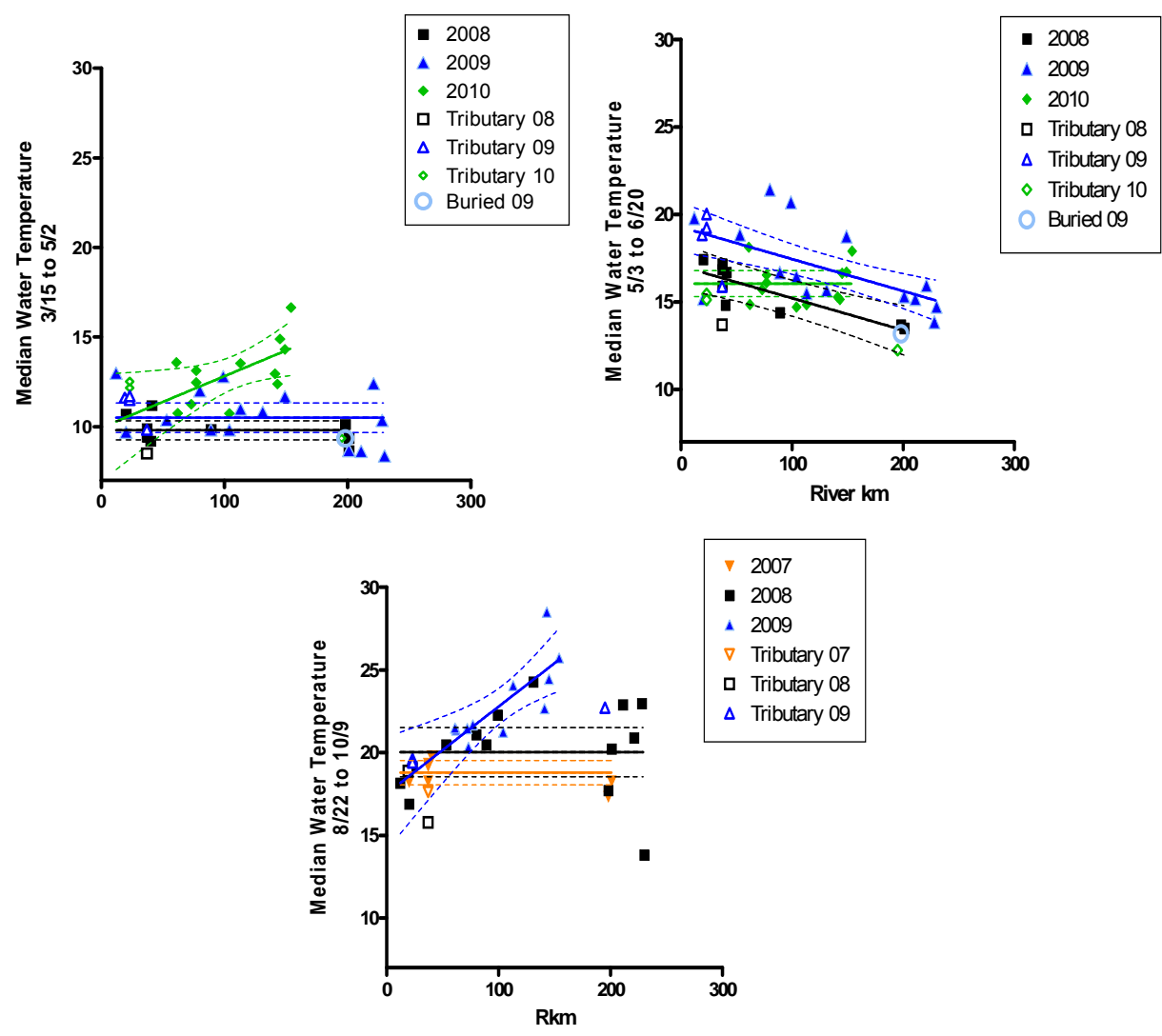

Figure 2.15. Median 7-day average daily maximum water temperature at each site for the March 15-May 2 period (above left), the May 3-June 20 period (above right), and the August 22-October 9 period (lower left) with regression lines and 95\% confidence intervals.

\subsubsection{Channel Morphology and Inundation}

For the most part, statistical tests did not distinguish metrics of channel morphology by EM zone, because morphology is generally similar throughout the LCRE (Table 2.18). Elevations are provided for the thalweg (lowest point in the channel bed) and channel bank, and the difference is termed "depth". Cross-sectional area and channel top width are also given. The inundation frequencies were calculated on an annual basis and for a March to July fish migration period, at a 50-cm water depth in the channel to accommodate fish passage and a $10-\mathrm{cm}$ water depth on the floodplain. The only statistically significant difference using only emergent marshes was in the width-to-depth ratio (Kruskal-Wallis: $\mathrm{n}=35$, $\mathrm{p}=0.002)$, and this result was driven by the difference between tributaries and all other EM zones (Figure 2.16). 
Table 2.18. Channel morphology at the mouth and inundation frequencies from sites located in the LCRE floodplain. Emergent marsh sites are ordered longitudinally from the river mouth to the upper extent of monitoring at rkm 230, followed by shrub and forested sites. EM zones are provided for reference; tributary sites are designated by EM1-T in the EM zone column.

\begin{tabular}{|c|c|c|c|c|c|c|c|c|c|c|c|}
\hline \multirow[b]{3}{*}{ EM Zone } & \multirow[b]{3}{*}{$\begin{array}{l}\text { River } \\
\text { kilometer } \\
\text { (rkm) }\end{array}$} & \multirow{2}{*}{\multicolumn{6}{|c|}{ Physical Metrics }} & \multicolumn{4}{|c|}{ Inundation Frequency } \\
\hline & & & & & & & & \multicolumn{2}{|c|}{ Annual } & \multicolumn{2}{|c|}{ March-July } \\
\hline & & $\begin{array}{l}\text { Bank Elev. } \\
\text { (m, CRD) }\end{array}$ & $\begin{array}{l}\text { Thalweg } \\
\text { Elev. } \\
\text { (m, CRD) }\end{array}$ & $\begin{array}{c}\text { Channel } \\
\text { Depth (m) }\end{array}$ & $\begin{array}{c}\text { Cross- } \\
\text { Section } \\
\text { Area }\left(\mathrm{m}^{2}\right)\end{array}$ & $\begin{array}{c}\text { Channel } \\
\text { Width (m) }\end{array}$ & $\begin{array}{l}\text { Width: } \\
\text { Depth } \\
\text { Ratio }\end{array}$ & $\begin{array}{l}\text { Thalweg } \\
\text { Elev. } \\
+50 \mathrm{~cm}\end{array}$ & $\begin{array}{l}\text { Bank } \\
\text { Elev. } \\
+10 \mathrm{~cm}\end{array}$ & $\begin{array}{l}\text { Thalweg } \\
\text { Elev. } \\
+50 \mathrm{~cm}\end{array}$ & $\begin{array}{c}\text { Bank } \\
\text { Elev. } \\
+10 \mathrm{~cm}\end{array}$ \\
\hline \multicolumn{12}{|c|}{ Emergent Marshes } \\
\hline EM1 & 6 & 1.6 & 0.9 & 0.7 & 3.5 & 6.3 & 9.3 & ND & ND & $48 \%$ & $35 \%$ \\
\hline EM1 & 12 & 1.0 & 0.6 & 0.4 & 2.5 & 13.4 & 34.9 & $72 \%$ & $74 \%$ & $70 \%$ & $72 \%$ \\
\hline EM1 & 12 & 1.7 & 0.6 & 1.1 & 21.2 & 30.9 & 27.2 & ND & ND & ND & ND \\
\hline EM1-T & 19 & 2.1 & -0.2 & 2.3 & 21.4 & 19.9 & 8.7 & $100 \%$ & $16 \%$ & $50 \%$ & $8 \%$ \\
\hline EM1 & 20 & 1.4 & 0.5 & 0.9 & 7.4 & 18.3 & 21.5 & $67 \%$ & $49 \%$ & $67 \%$ & $48 \%$ \\
\hline EM1-T & 23 & 0.9 & 0.4 & 0.5 & 1.0 & 3.2 & 6.3 & $72 \%$ & $68 \%$ & $70 \%$ & $67 \%$ \\
\hline EM1-T & 23 & 2.3 & -1.3 & 3.6 & 54.5 & 26.0 & 7.3 & $100 \%$ & $16 \%$ & $100 \%$ & $14 \%$ \\
\hline EM1-T & 23 & 2.6 & -0.3 & 2.9 & 24.3 & 13.9 & 4.8 & ND & ND & ND & ND \\
\hline EM1 & 37 & 1.3 & 0.3 & 1.1 & 18.4 & 22.5 & 21.3 & $76 \%$ & $49 \%$ & $74 \%$ & $47 \%$ \\
\hline EM1 & 39 & 1.0 & 0.7 & 0.3 & 1.4 & 8.7 & 32.4 & ND & ND & ND & ND \\
\hline EM2 & 41 & 1.9 & -2.3 & 4.2 & 91.3 & 41.7 & 9.8 & $95 \%$ & $22 \%$ & $95 \%$ & $21 \%$ \\
\hline EM2 & 53 & 1.9 & 0.0 & 1.9 & 37.1 & 24.8 & 12.9 & $97 \%$ & $28 \%$ & $97 \%$ & $29 \%$ \\
\hline EM2 & 61 & 1.9 & 0.2 & 1.7 & 36.6 & 36.5 & 21.3 & $81 \%$ & $22 \%$ & $83 \%$ & $23 \%$ \\
\hline EM2 & 71 & 0.8 & 0.4 & 0.4 & 9.6 & 47.7 & 115.9 & $75 \%$ & $75 \%$ & $81 \%$ & $80 \%$ \\
\hline EM2 & 72 & 1.5 & 0.5 & 1.0 & 21.8 & 39.5 & 37.6 & $74 \%$ & $42 \%$ & $79 \%$ & $47 \%$ \\
\hline EM2 & 77 & 1.8 & 0.7 & 1.2 & 51.3 & 72.1 & 62.2 & $61 \%$ & $24 \%$ & $67 \%$ & $28 \%$ \\
\hline EM2 & 80 & 2.1 & 0.7 & 1.5 & 12.9 & 15.2 & 10.4 & $74 \%$ & $17 \%$ & $80 \%$ & $21 \%$ \\
\hline EM2 & 89 & 1.4 & 0.8 & 0.6 & 6.8 & 16.6 & 27.4 & $55 \%$ & $43 \%$ & $65 \%$ & $52 \%$ \\
\hline EM2 & 99 & 2.5 & -0.4 & 2.9 & 47.0 & 29.4 & 10.0 & $92 \%$ & $69 \%$ & $98 \%$ & $82 \%$ \\
\hline EM2 & 100 & 1.2 & 1.0 & 0.2 & 1.1 & 13.1 & 79.1 & $48 \%$ & $62 \%$ & $62 \%$ & $76 \%$ \\
\hline EM3 & 113 & 0.9 & -0.8 & 1.7 & 26.7 & 73.0 & 42.8 & $100 \%$ & $64 \%$ & $100 \%$ & $77 \%$ \\
\hline
\end{tabular}


Table 2.18. (contd)

\begin{tabular}{|c|c|c|c|c|c|c|c|c|c|c|c|}
\hline \multirow[b]{3}{*}{ EM Zone } & \multirow[b]{3}{*}{$\begin{array}{l}\text { River } \\
\text { kilometer } \\
\text { (rkm) }\end{array}$} & \multirow{2}{*}{\multicolumn{6}{|c|}{ Physical Metrics }} & \multicolumn{4}{|c|}{ Inundation Frequency } \\
\hline & & & & & & & & \multicolumn{2}{|c|}{ Annual } & \multicolumn{2}{|c|}{ March-July } \\
\hline & & $\begin{array}{l}\text { Bank Elev. } \\
\text { (m, CRD) }\end{array}$ & $\begin{array}{l}\text { Thalweg } \\
\text { Elev. } \\
\text { (m, CRD) }\end{array}$ & $\begin{array}{l}\text { Channel } \\
\text { Depth (m) }\end{array}$ & $\begin{array}{c}\text { Cross- } \\
\text { Section } \\
\text { Area }\left(\mathrm{m}^{2}\right)\end{array}$ & $\begin{array}{c}\text { Channel } \\
\text { Width (m) }\end{array}$ & $\begin{array}{l}\text { Width: } \\
\text { Depth } \\
\text { Ratio }\end{array}$ & $\begin{array}{l}\text { Thalweg } \\
\text { Elev. } \\
+50 \mathrm{~cm}\end{array}$ & $\begin{array}{c}\text { Bank } \\
\text { Elev. } \\
+10 \mathrm{~cm}\end{array}$ & $\begin{array}{l}\text { Thalweg } \\
\text { Elev. } \\
+50 \mathrm{~cm}\end{array}$ & $\begin{array}{l}\text { Bank Elev. } \\
\quad+10 \mathrm{~cm}\end{array}$ \\
\hline EM3 & 114 & 0.6 & 0.4 & 0.2 & 1.9 & 63.7 & 374.5 & $67 \%$ & $82 \%$ & $79 \%$ & $92 \%$ \\
\hline EM3 & 121 & 1.2 & 0.5 & 0.7 & 16.0 & 33.3 & 44.7 & ND & ND & ND & ND \\
\hline EM3 & 123 & 1.3 & 0.9 & 0.4 & 2.6 & 6.0 & 14.4 & ND & ND & ND & ND \\
\hline EM4 & 145 & 1.2 & 0.7 & 0.4 & 3.7 & 19.7 & 45.1 & $51 \%$ & $47 \%$ & $68 \%$ & $65 \%$ \\
\hline EM4 & 149 & 2.0 & 0.9 & 1.1 & 33.9 & 43.0 & 38.5 & $45 \%$ & $11 \%$ & $67 \%$ & $24 \%$ \\
\hline EM4 & 154 & 1.0 & 0.7 & 0.3 & 19.4 & 107.2 & 342.6 & $100 \%$ & $67 \%$ & $78 \%$ & $83 \%$ \\
\hline EM5 & 198 & 1.6 & 0.7 & 0.9 & 4.7 & 10.7 & 11.5 & $55 \%$ & $35 \%$ & $88 \%$ & $64 \%$ \\
\hline EM5 & 211 & 0.7 & 0.5 & 0.2 & 0.3 & 1.7 & 11.1 & $47 \%$ & $59 \%$ & $79 \%$ & $89 \%$ \\
\hline EM5 & 230 & 0.8 & -0.3 & 1.1 & 9.1 & 11.9 & 11.3 & $100 \%$ & $52 \%$ & $100 \%$ & $88 \%$ \\
\hline \multicolumn{12}{|c|}{ Shrub/Forested Wetlands } \\
\hline$<70 \mathrm{rkm}$ & 53 & 1.9 & 0.0 & 1.9 & 37.1 & 24.8 & 12.9 & $97 \%$ & $28 \%$ & $97 \%$ & $29 \%$ \\
\hline$>70 \mathrm{rkm}$ & 73 & 2.3 & -4.5 & 6.8 & 136.8 & 31.3 & 4.6 & ND & ND & ND & ND \\
\hline$<70$ rkm & 37 & 2.2 & -0.6 & 2.7 & 31.4 & 18.0 & 6.6 & ND & ND & ND & ND \\
\hline$<70 \mathrm{rkm}$ & 37 & 2.2 & 0.0 & 2.2 & 17.9 & 11.8 & 5.5 & ND & ND & ND & ND \\
\hline$<70$ rkm & 37 & 1.8 & -0.3 & 2.1 & 19.1 & 14.1 & 6.8 & $72 \%$ & $7 \%$ & $70 \%$ & $5 \%$ \\
\hline$<70$ rkm & 40 & 2.2 & -0.7 & 2.8 & 38.0 & 21.0 & 7.4 & ND & ND & ND & ND \\
\hline$>70 \mathrm{rkm}$ & 98 & 2.9 & -2.3 & 5.2 & 151.1 & 39.1 & 7.6 & ND & ND & ND & ND \\
\hline$>70 \mathrm{rkm}$ & 141 & 2.8 & 0.6 & 2.1 & 48.6 & 29.4 & 13.9 & ND & ND & ND & ND \\
\hline
\end{tabular}




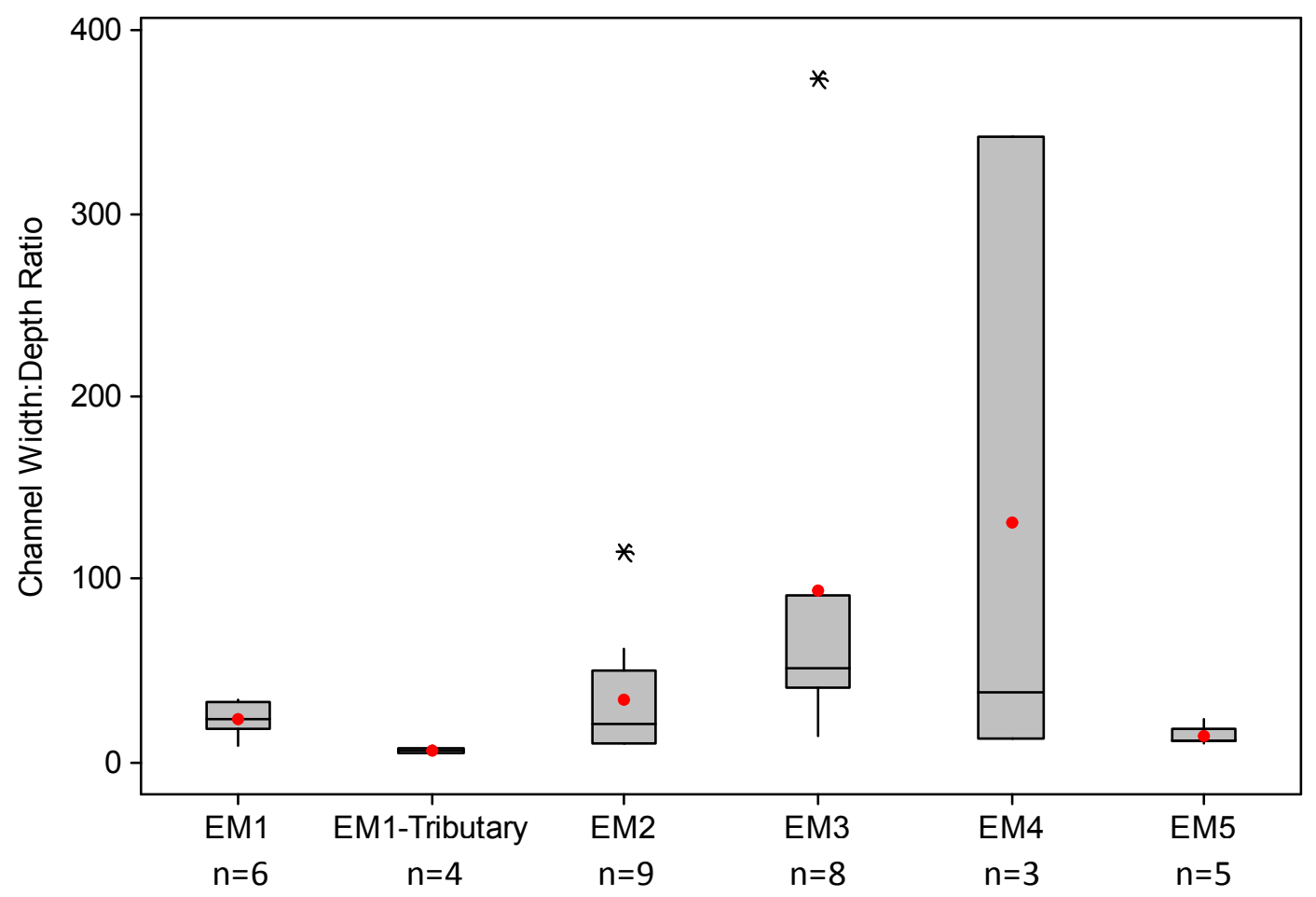

Figure 2.16. The channel width-to-depth ratios measured at the channel mouth in emergent marshes.

\subsection{Summary}

This section explores the variability of plant communities, plant species distribution, and environmental factors across five EM zones of the LCRE, and tributary rivers to EM1. Six wetland types are included in the assessment of data from 55 sites: main-stem emergent marsh (including low- and high-elevation marsh), tributary marsh, shrub-dominated wetland, main-stem swamp (evergreen forested wetlands), tributary swamp, and riparian (deciduous forested wetland).

This assessment is based on a synthesis of previously existing tidal wetland data on plants and the physical environment from five studies. The sample size of emergent marshes (43) provides greater confidence in the statistical results of this assessment than we have for other wetland types in the LCRE. This analysis relied on existing data, which collectively subsample the dynamic and spatially complex LCRE region, but comprise unequal sample sizes between EM zones and wetland types. Therefore, the conclusions of statistical tests herein may be either strengthened or altered once further data are collected under programs such as Ecosystem Monitoring by the EP and Bonneville Power Administration.

One site, Hardy Creek, while part of the LCRE ecosystem, exhibits a lack of connectivity and high elevation, low SEV, and vegetation anomalies such as the presence of upland species Plantago latifolia. While we have only collected data at one such site, further study may identify other such areas within the spatial boundary of the historical LCRE floodplain with intermittent connectivity. A great deal of uncertainty about the number of such sites and their characteristics remains. 



\subsection{Disturbance History of Reference Wetlands}

The focus of this chapter is on the classification of tidally influenced wetlands of the LCRE by disturbance history, and examining the ability of this classification to discriminate ecological structures and processes, to provide a basis for determining successional trends as a result of restoration and creation actions.

\subsection{Methods}

\subsubsection{Site Selection}

This analysis includes all sites in the LCRE at which PNNL has previously collected environmental and plant community data. Thus, data from a total of 55 reference sites and 3 recently restored sites, representing 6 wetland types and 6 disturbance history categories, are presented herein.

\subsubsection{Land-Cover Data Analysis}

Two data sets were used in the land-cover data analysis. The first is a digitized representation of the land cover from historical maps from the late 1800s covering most of the LCRE (Burke 2010). The second data set is a digital representation of the current land cover that was developed in 2011 (Keith Marcoe, EP, personal communication, 2012). The two polygon data sets were each clipped to two different scales: 1) the study area scale, which included the larger area surrounding the sites, and 2) the site scale, which included the just the area of the vegetation survey at the sites. The areas of resulting land-cover polygons were calculated and the cover classes merged into similar categories for comparison between historical and current data sets.

\subsubsection{Disturbance History Classification}

The classification of sites according to disturbance history was limited by available information. The scale is from 0 , the least disturbed, to 5, which is arguably the most disturbed or at least the most recently disturbed (Table 3.1, Figure 3.1). Thus, we also refer to disturbance history classes as levels of disturbance. The classification is largely defined by the geographic scale of disturbance to hydrologic and sedimentary processes: site, local, or landscape. Although landscape disturbances - changes to hydrologic and sedimentary processes at the basin scale - define one category, these types of landscape disturbances may be assumed to apply to all sites in the LCRE, including those with additional documented local or on-site disturbances. The classification of sites is limited by the historical information about factors influencing sedimentary and hydrologic processes that was available to us at the outset of this research, and thus does not include site-specific logging history or the Corps' pile-dike inventory (AECOM 2011). For the present analysis, pile dikes are classified as a local disturbance, and are only included if we observed them during field data collection; because many of them have become buried or submerged from view, our analysis likely underestimates the size of this category, and includes some pile-dike-associated sites in the dredged material placement category, as described below. 
Table 3.1. Short descriptions of disturbance history categories, with numerical codes.

\begin{tabular}{cl}
\hline $\begin{array}{c}\text { Disturbance } \\
\text { Code }\end{array}$ & \\
\hline 0 & Least disturbed, present in 1870 \\
1 & Landscape disturbance only, e.g., effects of hydrosystem, water withdrawals, systematic diking \\
2 & Additional local disturbance, e.g., jetty or channel routing nearby \\
3 & On-site disturbance: previously diked \\
4 & On-site disturbance: associated with dredged material placement \\
5 & Recently reconnected, e.g., recent dike breach \\
NA & Unknown \\
\hline
\end{tabular}

0. Least Disturbed, Present in 1870 . There are only two marsh sites that were fully present in 1870 : Grant Island and Secret River high and low marshes. All of the other sites present in 1870 have shrub and forest cover.

1. Landscape Disturbance Only. This category represents sites at which no known local or site disturbance has occurred. However, these sites were not vegetated in 1870; typically, they were open water or sand flat. Therefore, we call them "landscape disturbance only" sites to reference the fact that changes to hydrologic and sedimentary processes at the Basin scale are the only known reasons for the progradation and aggradation of these sites, i.e., through sediment deposition from reduced freshet flows and other changes to hydrologic processes seen throughout the LCRE. Often they were partially vegetated in 1870 or are adjacent to areas that were vegetated in 1870 .

2. Local Disturbance. This category represents a large number of local disturbance types, including trestles (e.g., Young's Bay), jetties (e.g., Trestle Bay), dikes, pile dikes, and changes to river mouth morphology (e.g., Washougal, Clatskanie). These disturbances near to the wetland sites typically affected hydrologic and sedimentary processes, in addition to the landscape-scale disturbances described in category 1 .

3. Site Disturbance (Previously Diked). We have previously called this category "historically breached" or "naturally breached" sites (Diefenderfer et al. 2010) and it contains the three sites sampled as part of the Corps' Cumulative Effects project: Haven, Karlson, and Ft. Clatsop.

4. Site Disturbance (Associated with Dredged Material Placement). Generally, this category is intended to include dredged material placement. However, without further in-depth investigation, we cannot be sure whether category 4 sites all had placement directly on the sampled area; they may have had dredged material placement nearby. The information we used to assign this code is from our direct observations and review of reporting by PC Trask and Associates (2009). Our field observations suggest that the majority of these sites had pile dikes nearby, which may have contributed to net deposition effect.

5. Recently Reconnected. This category includes sites that were recently restored using hydrologic reconnection techniques, e.g., dike breach, tide gate, and channel excavation. The Cumulative Effects project sites Kandoll Farm, Vera Slough, and Crims Island are examples, but also illustrate the apparent problems with defining these sites as a single category given their widely different land use history and different levels of current hydrologic connectivity (Haskell and Tiffan 2011; Borde et al. 2012a; Johnson et al. 2012). 


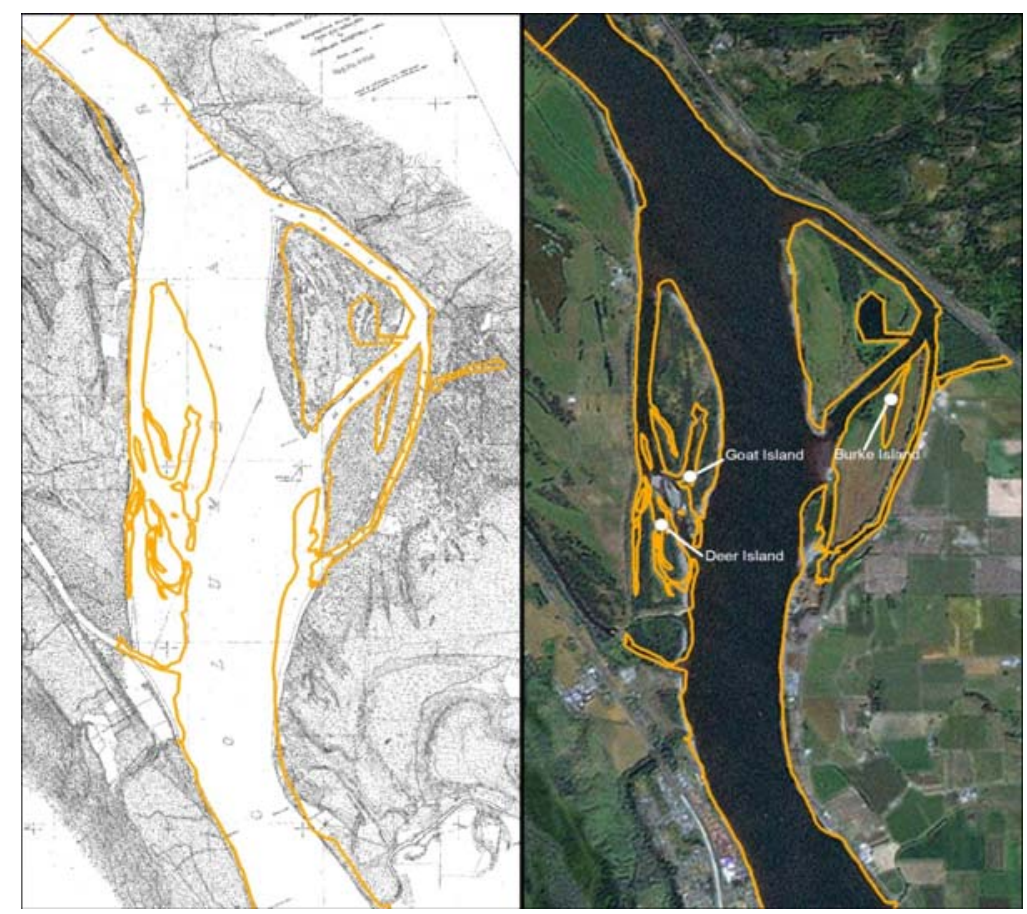

Figure 3.1. Examples of disturbance history analysis. Goat Island and Deer Island sites (disturbance category 4) were not present on the historical maps. Burke Island (disturbance category 1) was present, but much less area was classified as wetland.

\subsubsection{Data Collection}

Primary data collection methods for plant cover, sediment accretion, channel cross-section surveys, water surface elevation, and land elevation surveys followed protocols in Roegner et al. (2009). However, the Corps' Cumulative Effects study team collected data experimentally to develop the protocols, by, so methods varied somewhat prior to finalization of the protocols in 2009. Project-specific data collection information is available in the annual report series of the Corps' Cumulative Effects study (EST-02-P-04) (Johnson et al. 2011), and in the EP's Ecosystem Monitoring and Reference Sites reports (Borde et al. 2011, 2012a, 2012b; www.estuarypartnership.org). In addition to the primary methods, a 10 -cm sediment core was collected at most sites, both in the channel and from the marsh/swamp plain (Borde et al. 2011). These samples were analyzed for grain size and TOC content by Columbia Analytical Services in Kelso, Washington.

Between 2005 and 2011, plant-cover data collected comprised data from 3518 plots from six wetland types designated as main-stem marsh, tributary marsh, main-stem swamp, tributary swamp, riparian, and shrub. Seven of the main-stem marsh sites were sampled 2 or more years, with two sites assessed for 7 years. The remaining main-stem marsh sites and all other wetland types were assessed for 1 year. Typically, pressure gauges and sediment accretion stakes were deployed in July or August, and retrieved a year later when the remaining environmental data were collected. For a summary of the number of sites, transects, and quadrats sampled for plant cover, please see Table 18 (Section 2). 


\subsubsection{Measurement of Distance to Main Channel}

Distance from main channel was determined for each site as follows:

- Main channel sites: Sites sharing a boundary with either the Columbia River or a side channel of the River (e.g., channel between an island and the mainland) were considered to have a distance of 0 kilometers $(\mathrm{km})$ from the main channel.

- Bay sites: An imaginary line was delineated across the mouth of the four bays located in the study area: Baker Bay, Youngs Bay, Grays Bay, and Cathlamet Bay. The line was drawn straight across the mouth from the two outermost points of the Bay. Distances for sites sharing a boundary with a bay were then measured from the site to the bay-mouth boundary line.

- Back-water and tributary sites: Distance from the main channel was determined by creating a line feature using geographic information systems (GIS) from the closest sampling area within the site to the water body considered the main channel (as defined above). This category includes sites in the interior of islands on the main-stem river.

\subsubsection{Statistical Methods}

The objective of the statistical analysis was to determine if differences observed in channel morphology, floodplain and sediment characteristics, species cover, and wetland community characteristics could be associated with differences in levels of disturbance. Differences in physical and community characteristics could also be associated with the location along the river or the distance from the main channel of the Columbia River. Both variables reflect changes in the energy associated with a site and potential barriers to the propagation or movement of plant species. The EM zones were determined based on the combined differences in hydrologic characteristics as well as community structure.

The following variables were characterized as a function of EM zone, distance from the main channel, and level of disturbance: plant relative cover (major, native and non-native); total numbers of native and non-native species; the number of species per quadrat (a measure of patchiness); absolute cover of PHAR; and the ratio of PHAR to non-native cover. Site characteristics including sediment accretion rate, TOC, grain size, channel morphology and floodplain characteristics were evaluated as a function of the ranked distance to the main channel and the level of disturbance. Additionally, sediment characteristics (i.e., grain size and TOC) measured within the wetland defined by the plant strata and within the channel were compared among wetland types and plant strata (for those characteristics measured in the marsh) using the nonparametric Kruskal-Wallis test.

Descriptive statistics, dot plots, ANOVA and Tukey's multiple comparisons, and the nonparametric Kruskal-Wallis test on medians were conducted in Minitab Version 16, Minitab Inc., 2010. In the summary, we provide descriptive statistics including the first and third quartile results to provide a nonparametric interval of generally more likely results. Dot plots show the mean (horizontal line), and each data point within a column associated with the grouping variable. For parametric analysis, assumptions of normality and homogeneity of within-class variance were assessed using normal probability and residual plots. Cover data were arcsine square root transformed to reduce within-class heterogeneity. When parametric assumptions could not be met or sample sizes were small $(n<10)$, the nonparametric Kruskal-Wallis test and the Tukey's multiple comparisons test on the ranked data were used where appropriate. Regression analysis was conducted using Prism, Version 4.0, GraphPad Software Inc., 1992-2003. 
Discriminant analysis by level of disturbance and EM zone was conducted using standardized physical, morphological, and sediment characteristics of all marshes; to standardize data, the mean is subtracted from the response and the result divided by the standard deviation. Discriminant analysis by level of disturbance and by EM zone was also conducted using standardized community metrics: absolute cover of PHAR, total number of species, number of species per quadrat, native cover, and the ratio of PHAR to non-native cover. Statistica Software, Version 9.1, StatSoft, Inc. (1984-2010) was used for discriminant analysis.

Hierarchical cluster analysis of all marsh sites was conducted using standardized channel and floodplain variables (i.e., observation minus the mean and then divided by the standard deviation). Variables used in the analysis were determined by the best discriminant model. However, the pairwise correlations were also calculated with the intention of minimizing the number of highly correlated variables used in the discriminant and cluster analyses.

Cluster analysis of marsh sites from EM2 through EM5 using average cover data for 35 major plant species (having at least 10 non-zero cover observations) was conducted using Euclidean distance and complete linkage:

$$
d=\sqrt{\sum_{i=1}^{n}\left|x_{i}-y_{i}\right|^{2}}
$$

In complete linkage, the distance between two clusters is computed as the maximum distance between a pair of objects, one in one cluster, and one in the other.

We calculated similarity indices for the average site herbaceous cover and for the average cover for marsh sites from EM2 through EM5. The Bray-Curtis similarity coefficient (S'):

$$
\frac{\sum_{i=1}^{i=n}\left|s_{i 1}-s_{i 2}\right|}{\sum_{i=1}^{i=n}\left(s_{i 1}+s_{i 2}\right)}
$$

was used as a measure of distance between sites using the PRIMER Version 5.2.9 (Plymouth Routines In Multivariate Ecological Research) software package developed at the Plymouth Marine Laboratory (Clarke and Warwick 1994; Clarke and Gorley 2006). The coefficient S' ranges from 0 if two stations have no species in common to 1 if two stations have all species at the same abundance. The average cover data were not standardized. A horizontal, hierarchical dendrogram was used to provide a visual diagram of the linkage distance between sites and clusters of stations. Linkage is based on an unweighted-pair group average. The distance between any two clusters $\mathrm{A}$ and $\mathrm{B}$ is taken to be the average of all distances between pairs of observations " $x$ " in A and " $y$ " in B, that is, the mean distance between elements of each cluster. Clusters combined at greater linkage distance are more dissimilar than those combined at smaller linkage distances. A non-metric, multi-dimensional scaling (nMDS) ordination plot was also used to show similarity in two or three dimensions. Observations are iteratively positioned in space until the distance between observations agrees with their similarity (measured by a stress statistic). Stress is a measure of the goodness-of-fit of a nonparametric regression of the similarity on the inter-object distances in n-dimensional space. Small stress values $(0<$ stress $<0.1)$ indicate that 
the distances between points on the nMDS plot closely match the similarity values from the Bray-Curtis matrix. The final orientation is arbitrary and relates to the relative distances between observations.

\subsection{Results}

In this section, the results of land-cover and other data analysis to determine disturbance level are first presented. Following this, the analysis of landscape position relative to disturbance level is presented, using distance of the site from the main channel as one proxy for habitat connectivity. Other descriptive statistics of average floodplain elevation and proportion of low marsh for each disturbance level are also provided as additional context for the analysis of environmental factors by disturbance level.

The descriptive statistics and analytical results for disturbance levels are presented together for each physical controlling factor metric, such as sediment characteristics and hydrologic processes. Following these, we present plant community response variables. As appropriate, the effect of the distance of sites from the main channel is also presented with the physical and plant community metrics, in an attempt to isolate that factor from other differences between sites, because it would be expected that main-stem river hydrologic and sedimentary processes may have an effect. Following the enumeration of results by metric, discriminant models of disturbance categories using all marshes, based on the physical features of channel morphology and floodplain characteristics; community characteristics; and EM zones, are compared and contrasted to bring together the results of Section 2 and Section 3. Finally, we present analyses of similarity for the physical and floodplain characteristics and plant community characteristics.

\subsubsection{Land-Cover Data Analysis and Disturbance Level}

Analysis of land-cover data determined that 2 marshes and all 8 forested and shrub-dominated sites were historically present (category 0) (Table 3.2). For 10 marshes, we did not find evidence of local or site scale disturbance, so these were classified as having landscape-scale disturbance only (category 1). For 9 marshes, we found evidence of local disturbances such as trestles, jetties, dikes, pile dikes, and changes to river mouth morphology (category 2). Three marshes were identified and sampled as part of the Corps' Cumulative Effects study as examples of previously diked sites (category 3 ). Twenty marshes were identified as having had dredged material placement, though our field observations suggest that many of these may also have had pile dikes nearby, which may have contributed to net deposition effect (category 4). Three sites were identified and sampled as part of the Corps' Cumulative Effects study as examples of restoration sites where hydrologic reconnection had recently occurred, through dike breaches, tide gates, and channel excavation (category 5). For 2 sites, insufficient historical data existed to determine whether sites were historically present (category NA). 
Table 3.2. Sites characteristics and results of land-cover analysis.

\begin{tabular}{|c|c|c|c|c|c|c|c|c|c|c|}
\hline $\begin{array}{c}\text { Site } \\
\text { Disturbance } \\
\text { Code } \\
\end{array}$ & Site & Name & Zone & River km & $\begin{array}{c}\text { Number of } \\
\text { Transect }(\mathrm{m})\end{array}$ & $\begin{array}{c}\text { Number of } \\
\text { Quadrats }\end{array}$ & $\begin{array}{c}\text { Year } \\
\text { Sampled }\end{array}$ & $\begin{array}{c}\text { Distance } \\
\text { from Main } \\
\text { Channel }(\mathrm{m})\end{array}$ & Type & Location \\
\hline 0 & GIM & Grant Island & EM1 & 23 & 5 & 20 & 2009 & 10,266 & Marsh & Tributary \\
\hline 0 & SRM & Secret River (Low and High Marsh) & EM1 & 37 & 4 & 33 & 2008 & 3988 & Marsh & Bay \\
\hline 1 & WIM & Welch Island & EM2 & 53 & 4 & 20 & 2008 & 625 & Marsh & Mainstem \\
\hline 1 & RIM & Ryan Island & EM2 & 61 & 5 & 25 & 2009 & 0 & Marsh & Mainstem \\
\hline 1 & MIM & Martin Island & EM3 & 129 & 3 & 97 & 2007 & 0 & Marsh & Mainstem \\
\hline 1 & BIM & Burke Island & EM3 & 131 & 7 & 32 & 2011 & 428 & Marsh & Mainstem \\
\hline 1 & SBM & Scappoose Bay & EM4 & 143 & 3 & 43 & 2010 & 3699 & Marsh & Mainstem \\
\hline 1 & CLM & Cunningham Lake & EM4 & 145 & 3 & $28-64$ & $2005-2011$ & 8680 & Marsh & Mainstem \\
\hline 1 & GAM & Gary Island & EM5 & 200 & 3 & 42 & 2008 & 0 & Marsh & Mainstem \\
\hline 1 & SIM & Sand Island (Rooster Rock) & EM5 & 211 & 3 & 73 & 2008 & 203 & Marsh & Mainstem \\
\hline 1 & FLM & Franz Lake & EM5 & 221 & $2-3$ & $43-63$ & $\begin{array}{l}2008 ; 2009 ; \\
\text { and } 2011\end{array}$ & 268 & Marsh & Mainstem \\
\hline 1 & PIM & Pierce Island & EM5 & 228 & 2 & 41 & 2008 & 0 & Marsh & Mainstem \\
\hline 2 & BBM & Baker Bay & EM1 & 6 & 4 & 40 & 2011 & 4159 & Marsh & Bay \\
\hline 2 & $\mathrm{CHM}$ & Chinook & EM1 & 12 & 4 & 40 & 2009 & 4946 & Marsh & Bay \\
\hline 2 & TBB & Trestle Bay & EM1 & 12 & 5 & 20 & 2008 & 953 & Marsh & Mainstem \\
\hline 2 & $\mathrm{LCM}$ & Lewis and Clark River mouth & EM1 & 20 & 8 & 46 & 2009 & 3318 & Marsh & Bay \\
\hline 2 & CRM & Clatskanie River & EM2 & 80 & 6 & 22 & 2009 & 773 & Marsh & Mainstem \\
\hline 2 & CS1 & Campbell Slough & EM4 & 149 & 2 & $23-64$ & $2005-2011$ & 1502 & Marsh & Mainstem \\
\hline 2 & WRM & Washougal River mouth & EM5 & 195 & 7 & 28 & 2010 & 353 & Marsh & Mainstem \\
\hline 2 & OSR & Old Sandy River Channel Marsh & EM5 & 196 & 3 & 68 & 2006 & 1430 & Marsh & Mainstem \\
\hline 2 & OSM & Old Sandy River mouth & EM5 & 198 & 3 & 105 & 2007 & 0 & Marsh & Mainstem \\
\hline 3 & FCB & Fort Clatsop & EM1 & 19 & 5 & 20 & 2008 & 7077 & Marsh & Tributary \\
\hline 3 & HIB & Haven Island & EM1 & 23 & 5 & 20 & 2009 & 10,907 & Marsh & Tributary \\
\hline 3 & KIB & Karlson Island & EM2 & 41 & 5 & 25 & 2008 & 3675 & Marsh & Mainstem \\
\hline 4 & MSC & Miller Sands & EM1 & 39 & 5 & 20 & 2009 & 616 & Marsh & Mainstem \\
\hline 4 & JIC & Jackson Island & EM2 & 71 & 8 & 32 & 2010 & 711 & Marsh & Mainstem \\
\hline 4 & WHC & Whites Island & EM2 & 72 & $5-7$ & $25-42$ & 2009-2011 & 742 & Marsh & Mainstem \\
\hline 4 & WAC & Wallace Island & EM2 & 77 & 6 & 40 & 2010 & 151 & Marsh & Mainstem \\
\hline 4 & GUC & Gull Island & EM2 & 89 & 10 & 30 & 2009 & 793 & Marsh & Mainstem \\
\hline 4 & LI1 & Lord Island 1 & EM2 & 99 & 4 & 55 & 2009 & 0 & Marsh & Mainstem \\
\hline 4 & LI2 & Lord Island 2 & EM3 & 100 & 5 & 23 & 2009 & 1066 & Marsh & Mainstem \\
\hline
\end{tabular}


Table 3.2. (contd)

\begin{tabular}{|c|c|c|c|c|c|c|c|c|c|c|}
\hline $\begin{array}{c}\text { Site } \\
\text { Disturbance } \\
\text { Code } \\
\end{array}$ & Site & Name & Zone & River km & $\begin{array}{c}\text { Number of } \\
\text { Transect }(\mathrm{m})\end{array}$ & $\begin{array}{c}\text { Number of } \\
\text { Quadrats }\end{array}$ & $\begin{array}{c}\text { Year } \\
\text { Sampled } \\
\end{array}$ & $\begin{array}{c}\text { Distance } \\
\text { from Main } \\
\text { Channel }(\mathrm{m})\end{array}$ & Type & Location \\
\hline 4 & DIB & Dibblee Slough & EM3 & 104 & 3 & 37 & 2005 & 405 & Marsh & Mainstem \\
\hline 4 & CI1 & Cottonwood Island 1 & EM3 & 113 & $2-3$ & $24-40$ & $\begin{array}{l}2005 \text { and } \\
2010\end{array}$ & 288 & Marsh & Mainstem \\
\hline 4 & $\mathrm{CI} 2$ & Cottonwood Island 2 & EM3 & 114 & 2 & $31-35$ & $\begin{array}{l}2005 \text { and } \\
2010\end{array}$ & 0 & Marsh & Mainstem \\
\hline 4 & SI1 & Sandy Island 1 & EM3 & 121 & 3 & 85 & 2007 & 104 & Marsh & Mainstem \\
\hline 4 & SI2 & Sandy Island 2 & EM3 & 123 & 3 & 111 & 2007 & 0 & Marsh & Mainstem \\
\hline 4 & GIC & Goat Island & EM3 & 131 & 7 & $31-32$ & $\begin{array}{c}2009 \text { and } \\
2011\end{array}$ & 417 & Marsh & Mainstem \\
\hline 4 & DIC & Deer Island & EM3 & 132 & 6 & 30 & 2011 & 342 & Marsh & Mainstem \\
\hline 4 & DSI & No-name Island & EM3 & 136 & 4 & 71 & 2007 & 0 & Marsh & Mainstem \\
\hline 4 & SCM & Sauvie Island East Slough & EM4 & 154 & 3 & 39 & 2005 & 1949 & Marsh & Mainstem \\
\hline 4 & WRC & Water Resources Center & EM4 & 175 & 3 & 84 & 2006 & 0 & Marsh & Mainstem \\
\hline 4 & MIC & McGuire Island & EM5 & 190 & 3 & 81 & 2006 & 0 & Marsh & Mainstem \\
\hline 4 & $\mathrm{CIC}$ & Chatham Island & EM5 & 201 & 3 & 105 & 2006 & 0 & Marsh & Mainstem \\
\hline 4 & RIC & Reed Island Fringe & EM5 & 201 & 4 & 40 & 2007 & 0 & Marsh & Mainstem \\
\hline 5 & VS & Vera Slough & EM1 & 19 & $5-10$ & $40-52$ & $\begin{array}{l}2005 ; 2006 ; \\
\text { and } 2009\end{array}$ & 145 & Marsh & Bay \\
\hline 5 & $\mathrm{KF}$ & Kandoll Farm & EM1 & 37 & $15-29$ & $96-127$ & $\begin{array}{l}2005 ; 2006 ; \\
\text { and } 2009\end{array}$ & 8142 & Marsh & Tributary \\
\hline 5 & $\mathrm{CI}$ & Crims Island & EM2 & 90 & $5-10$ & $25-30$ & $\begin{array}{l}2006 \text { and } \\
2009\end{array}$ & 242 & Marsh & Mainstem \\
\hline NA & CSM & Cooperage Slough & EM1 & 23 & 8 & 33 & 2007 & 10,282 & Marsh & Tributary \\
\hline NA & $\mathrm{HC}$ & Hardy Creek & EM5 & 230 & 2 & 40 & 2008 & 1730 & Marsh & Mainstem \\
\hline 0 & $\mathrm{CCS}$ & Crooked Creek & EM1 & 37 & 3 & 33 & 2007 & 4106 & Forested & Bay \\
\hline 0 & SRS & Secret River & EM1 & 37 & 9 & 56 & 2008 & 4674 & Forested & Bay \\
\hline 0 & SSS & Seal Slough & EM1 & 37 & 9 & 32 & 2009 & 10,627 & Forested & Tributary \\
\hline 0 & KIS & Karlson Island & EM2 & 40 & 10 & 24 & 2008 & 6002 & Forested & Bay \\
\hline 0 & $\mathrm{CCR}$ & Coal Creek Slough & EM2 & 98 & 6 & 24 & 2009 & 6221 & Forested & Mainstem \\
\hline 0 & GCR & Gee Creek & EM4 & 141 & 8 & 32 & 2010 & 0 & Forested & Mainstem \\
\hline 0 & WSH & Welch Island & EM2 & 53 & 8 & 38 & 2009 & 721 & shrub/scrub-historic & Mainstem \\
\hline 0 & WSS & Westport Slough & EM2 & 73 & 9 & 41 & 2010 & 4836 & shrub/scrub-historic & Mainstem \\
\hline
\end{tabular}




\subsubsection{Landscape Position: Distance from the Main Channel of the Columbia River}

The disturbance categories were described based on the distance of marsh and marsh-tributary sites from the main channel of the Columbia River. Differences between disturbance categories were significant, with previously diked sites (median distance 7,077 m) significantly further from the main channel than dredged material placement sites (median distance $288 \mathrm{~m}$ ) (Kruskal-Wallis, $\mathrm{p}=0.002$ ). Sites with dredged material placement are located nearer the main channel than local and landscape disturbance sites, and sites in the other disturbance categories are typically further away (Figure 3.2). Distance from the main channel was not significantly different between wetland types. These analyses do not represent all sites in these categories, however, only those sampled in these studies.

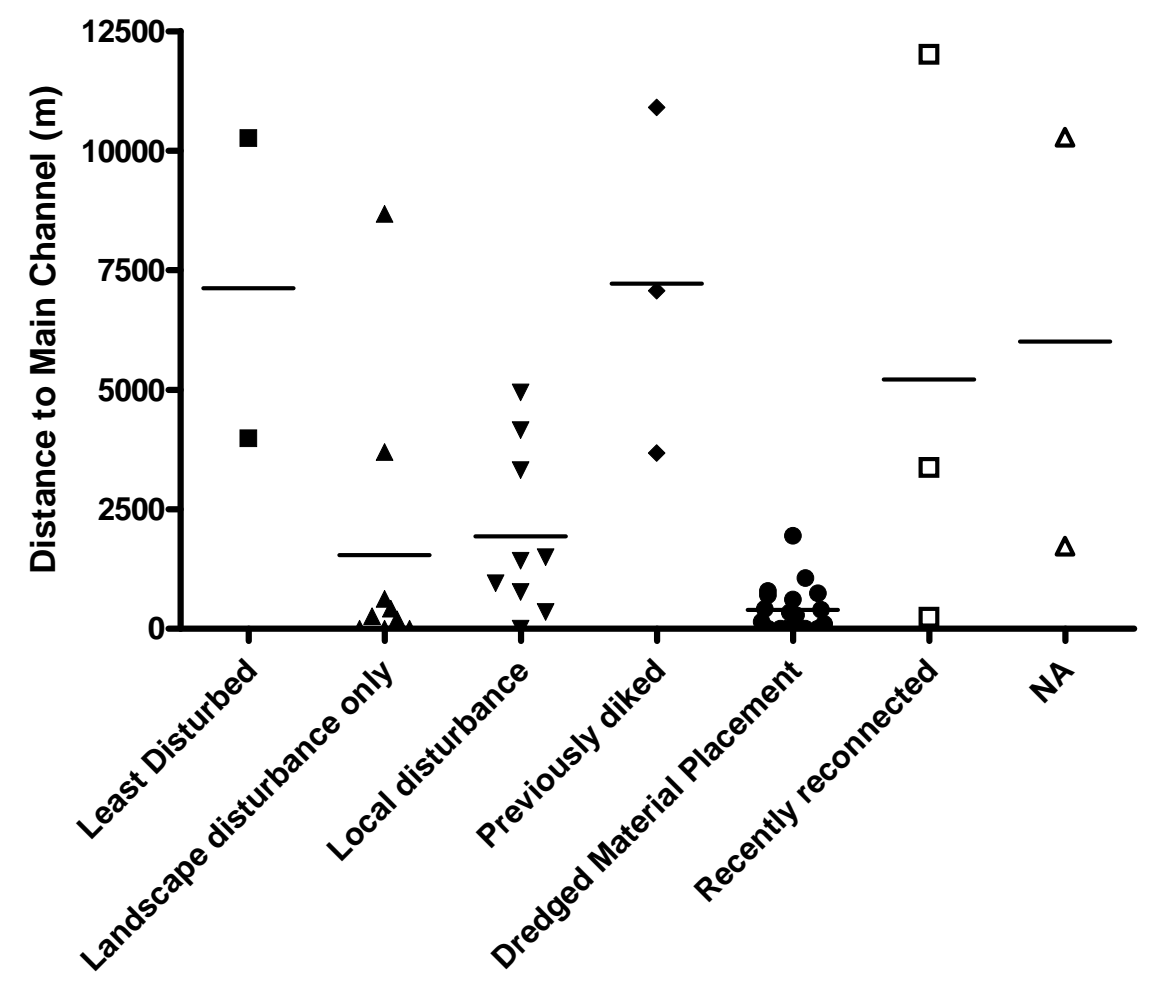

Figure 3.2. Distance to the main channel of sites in six disturbance categories

\subsubsection{Landscape Position: Average Site Elevation and Proportion of Low Marsh}

For main-stem marshes $(\mathrm{n}=42)$, significant differences in the average site elevation (Kruskal-Wallis, $\mathrm{p}=0.008$ ) (Figure 3.3) and the proportion of low marsh (Kruskal-Wallis, $\mathrm{p}=0.023$ ) (Figure 3.4) were found between the disturbance history categories. In particular, the elevation of the dredged material placement sites is lower than the locally disturbed sites, which is also reflected in the large proportion of low marsh. Note that figures include the tributary marshes. Regression on ranked distance to main channel of average site elevation $(n=42, p=0.102)$ and proportion of low marsh $(n=36$ with low marsh, $\mathrm{p}=0.524$ ) was not significant. Only one of the three recently reconnected sites (Vera Slough) was included in the analysis of the proportion of low marsh because Crims Island had no low marsh and Kandoll Farm is a tributary marsh. 


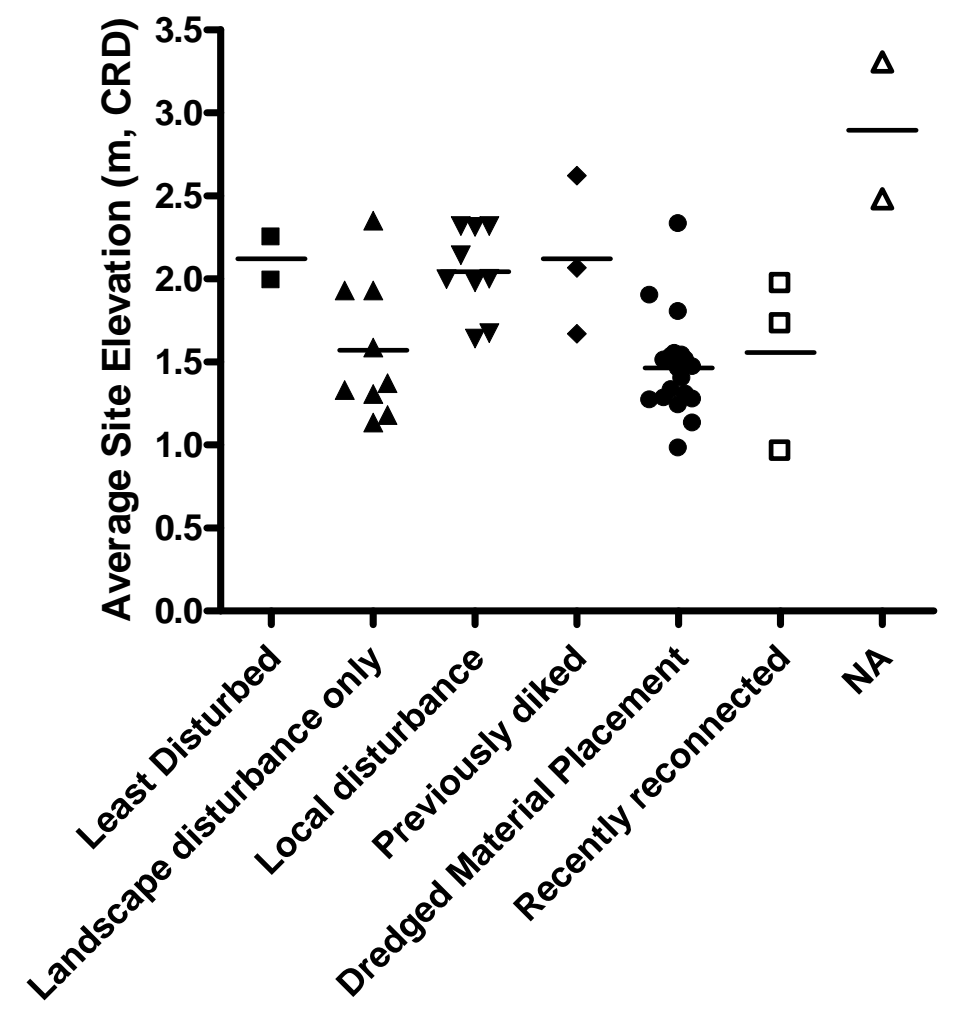

Figure 3.3. Average site elevation of sites ( $n=47$ including tributaries) in the disturbance categories.

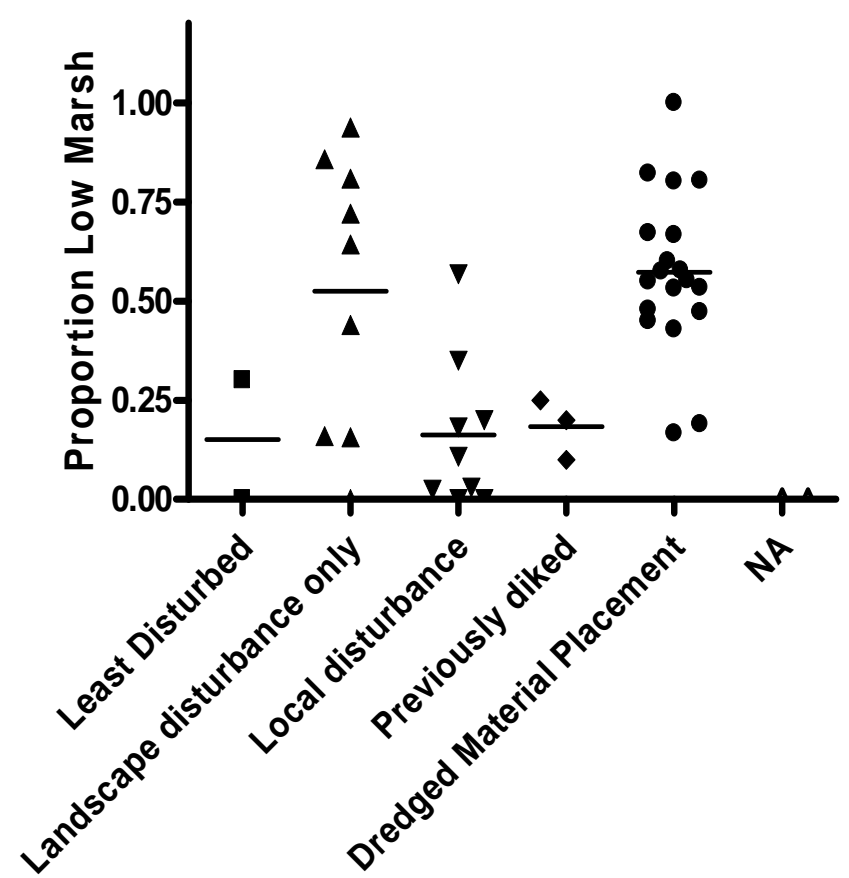

Figure 3.4. Proportion of low marsh at sites $(n=44$ including tributaries) in the disturbance categories. 


\subsubsection{Physical Controlling Factors and Ecosystem Processes}

The objective of this analysis is to explore the relationships between physical metrics, disturbance categories, and landscape position, as well as implications for controlling factors on plant community development.

\subsubsection{Sediment Accretion Rate}

Descriptive statistics of accretion or erosion rates were calculated for each disturbance history category (Table 3.3) and wetland type (Table 3.4.). Typically, these data were collected for one year at one location in the site. For marshes (main-stem and tributary, $n=31$ ), median accretion or erosion rates were not significantly different between sites categorized by levels of disturbance (Kruskal-Wallis, $\mathrm{p}=0.44$ ), although rates were notably higher at historically breached and recently breached sites (Table 3.3). A regression of accretion rates against the rank distance to the main channel was also not significant (Regression; degrees of freedom [d.f.] $=27 ; p=0.13$ ). Sediment was accreting at most sites between 0 and $2 \mathrm{~cm} /$ year. Sediment accretion or erosion rates were not significantly different between wetland types.

Table 3.3. Floodplain and channel sediment characteristics of main-stem river and tributary marshes by disturbance category (mean, range, and sample size).

\begin{tabular}{|c|c|c|c|c|c|c|c|}
\hline Variable & $0^{(\mathrm{a})}$ & 1 & 2 & 3 & 4 & 5 & NA \\
\hline $\begin{array}{c}\text { Yearly Accretion/ } \\
\text { Erosion Rate } \\
\left(\mathrm{cm}^{2}\right)\end{array}$ & $\begin{array}{c}0.69 \\
-0.13-1.50 \\
n=2\end{array}$ & $\begin{array}{c}-0.45 \\
-7.76-1.76 \\
n=6\end{array}$ & $\begin{array}{c}0.42 \\
-1.12-1.72 \\
n=6\end{array}$ & $\begin{array}{c}1.69 \\
1.14-2.55 \\
n=3\end{array}$ & $\begin{array}{c}0.95 \\
-0.22-3.69 \\
\mathrm{n}=11\end{array}$ & $\begin{array}{c}1.50 \\
1.16-1.91 \\
n=3\end{array}$ & $\mathrm{n}=0$ \\
\hline $\begin{array}{c}\text { Floodplain TOC } \\
(\%)\end{array}$ & $\begin{array}{c}4.49 \\
3.06-5.92 \\
n=2\end{array}$ & $\begin{array}{c}5.05 \\
2.23-8.37 \\
n=8\end{array}$ & $\begin{array}{c}5.55 \\
3.89-6.83 \\
n=6\end{array}$ & $\begin{array}{c}4.86 \\
4.84-4.88 \\
n=2\end{array}$ & $\begin{array}{c}2.05 \\
0.54-4.03 \\
n=10\end{array}$ & $\mathrm{n}=0$ & $\begin{array}{c}6.37 \\
6.37-6.37 \\
n=1\end{array}$ \\
\hline $\begin{array}{l}\text { Channel } \\
\text { TOC }(\%)\end{array}$ & $\begin{array}{c}2.72 \\
2.12-3.32 \\
n=2\end{array}$ & $\begin{array}{c}3.28 \\
1.14-7.21 \\
n=7\end{array}$ & $\begin{array}{c}3.41 \\
1.28-6.52 \\
n=6\end{array}$ & $\begin{array}{c}3.25 \\
1.34-5.16 \\
n=2\end{array}$ & $\begin{array}{c}1.69 \\
0.17-4.83 \\
n=9\end{array}$ & $\mathrm{n}=0$ & $\begin{array}{c}4.01 \\
4.01-4.01 \\
n=1\end{array}$ \\
\hline $\begin{array}{c}\text { Floodplain Gravel } \\
(\%)\end{array}$ & $\begin{array}{c}7.0 \\
1.4-12.5 \\
n=2\end{array}$ & $\begin{array}{c}1.6 \\
0.1-10.5 \\
n=8\end{array}$ & $\begin{array}{c}2.8 \\
0.0-15.3 \\
n=6\end{array}$ & $\begin{array}{c}7.7 \\
0.7-14.7 \\
n=2\end{array}$ & $\begin{array}{c}0.5 \\
0.0-1.6 \\
n=10\end{array}$ & $\mathrm{n}=0$ & $\begin{array}{c}27.3 \\
27.3-27.3 \\
n=1\end{array}$ \\
\hline $\begin{array}{c}\text { Floodplain Sand } \\
(\%)\end{array}$ & $\begin{array}{c}24.6 \\
23.3-25.9 \\
n=2\end{array}$ & $\begin{array}{c}29.7 \\
5.5-68.1 \\
n=8\end{array}$ & $\begin{array}{c}21.1 \\
12.2-38.9 \\
n=6\end{array}$ & $\begin{array}{c}18.7 \\
16.7-20.7 \\
n=2\end{array}$ & $\begin{array}{c}30.6 \\
9.5-53.1 \\
n=10\end{array}$ & $\mathrm{n}=0$ & $\begin{array}{c}70.3 \\
70.3-70.3 \\
n=1\end{array}$ \\
\hline $\begin{array}{l}\text { Floodplain Fines } \\
\qquad(\%)\end{array}$ & $\begin{array}{c}68.4 \\
64.2-72.7 \\
n=2\end{array}$ & $\begin{array}{c}68.7 \\
31.9-94.3 \\
n=8\end{array}$ & $\begin{array}{c}76.1 \\
60.9-87.5 \\
n=6\end{array}$ & $\begin{array}{c}73.6 \\
68.6-78.6 \\
n=2\end{array}$ & $\begin{array}{c}68.9 \\
46.9-90.4 \\
n=10\end{array}$ & $\mathrm{n}=0$ & $\begin{array}{c}2.4 \\
2.4-2.4 \\
n=1\end{array}$ \\
\hline $\begin{array}{c}\text { Channel } \\
\text { Gravel (\%) }\end{array}$ & $\begin{array}{c}1.8 \\
0.0-3.6 \\
n=2\end{array}$ & $\begin{array}{c}0.3 \\
0.0-1.4 \\
n=7\end{array}$ & $\begin{array}{c}0.5 \\
0.0-1.9 \\
n=6\end{array}$ & $\begin{array}{c}0.4 \\
0.2-0.5 \\
n=2\end{array}$ & $\begin{array}{c}0.1 \\
0.0-0.7 \\
n=9\end{array}$ & $\mathrm{n}=0$ & $\begin{array}{c}57.1 \\
57.1-57.1 \\
n=1\end{array}$ \\
\hline $\begin{array}{l}\text { Channel } \\
\text { Sand (\%) }\end{array}$ & $\begin{array}{c}18.5 \\
18.1-19.0 \\
n=2\end{array}$ & $\begin{array}{c}42.4 \\
10.0-94.6 \\
n=7\end{array}$ & $\begin{array}{c}38.2 \\
6.3-88.2 \\
n=6\end{array}$ & $\begin{array}{c}38.7 \\
25.1-52.2 \\
n=2\end{array}$ & $\begin{array}{c}48.7 \\
14.2-94.1 \\
n=9\end{array}$ & $\mathrm{n}=0$ & $\begin{array}{c}41.6 \\
41.6-41.6 \\
n=1\end{array}$ \\
\hline $\begin{array}{l}\text { Channel } \\
\text { Fines }(\%)\end{array}$ & $\begin{array}{c}79.7 \\
78.3-81.0 \\
n=2\end{array}$ & $\begin{array}{c}57.3 \\
5.0-90.0 \\
n=7\end{array}$ & $\begin{array}{c}61.3 \\
11.8-93.7 \\
n=6\end{array}$ & $\begin{array}{c}61.0 \\
47.3-74.6 \\
n=2\end{array}$ & $\begin{array}{c}51.2 \\
5.3-85.8 \\
n=9\end{array}$ & $\mathrm{n}=0$ & $\begin{array}{c}1.3 \\
1.3-1.3 \\
n=1\end{array}$ \\
\hline
\end{tabular}

(a) One sediment core was taken at Secret River marsh, so low and high marshes are not distinguished. 


\subsubsection{Sediment Grain Size, Total Organic Carbon, and Level of Disturbance}

For marshes (main-stem and tributary), sites categorized by level of disturbance did not significantly differ in any category of sediment grain size (Kruskal-Wallis, $p>0.14)$. However, median TOC (\%) observed within vegetation data collection areas on the floodplain were significantly different between sites categorized by levels of disturbance (Kruskal-Wallis, $p=0.025$ ) (Table 3.3). Sites associated with dredged material placement (median TOC $=2.1 \%$ ) had a lower TOC $(\%)$ than sites that experienced only landscape (median TOC $=4.6 \%$ ) or local disturbance (median TOC $=6.0 \%$ ), and lower TOC $(\%)$ than all other disturbance categories (Figure 3.5). The highest TOC (4.03\%) among dredged material placement sites is Gull Island created (GUC), which may be explained by its relatively lengthy time since establishment; however, this analysis cannot be conducted without additional information on the age of other sites. Median TOC (\%) from channel samples were lower than floodplain samples and were not significantly different between sites categorized by disturbance (Kruskal-Wallis, $p=0.37)$. TOC (\%) from both floodplain and channel samples significantly increased with rank distance to the main channel (Regression; d.f. $=26 ; \mathrm{p}=0.002$ and d.f. $=24 ; \mathrm{p}=0.01$, respectively) (Figure 3.6).

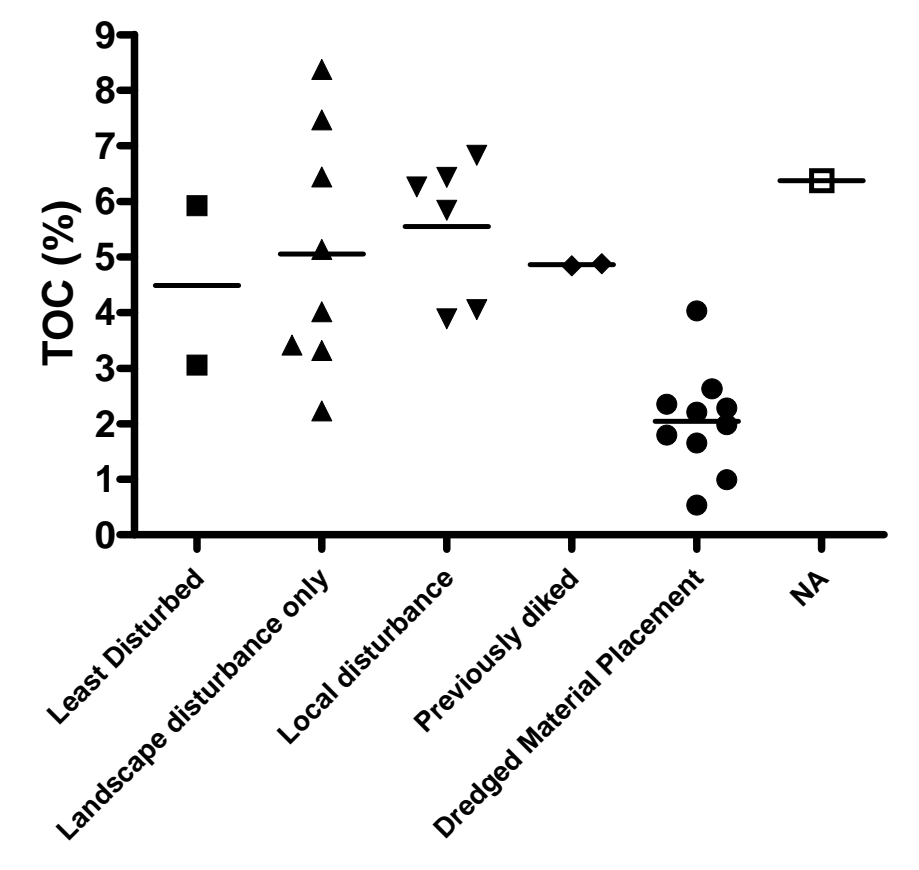

Figure 3.5. The TOC (\%) in vegetated soils of marshes and level of disturbance. 


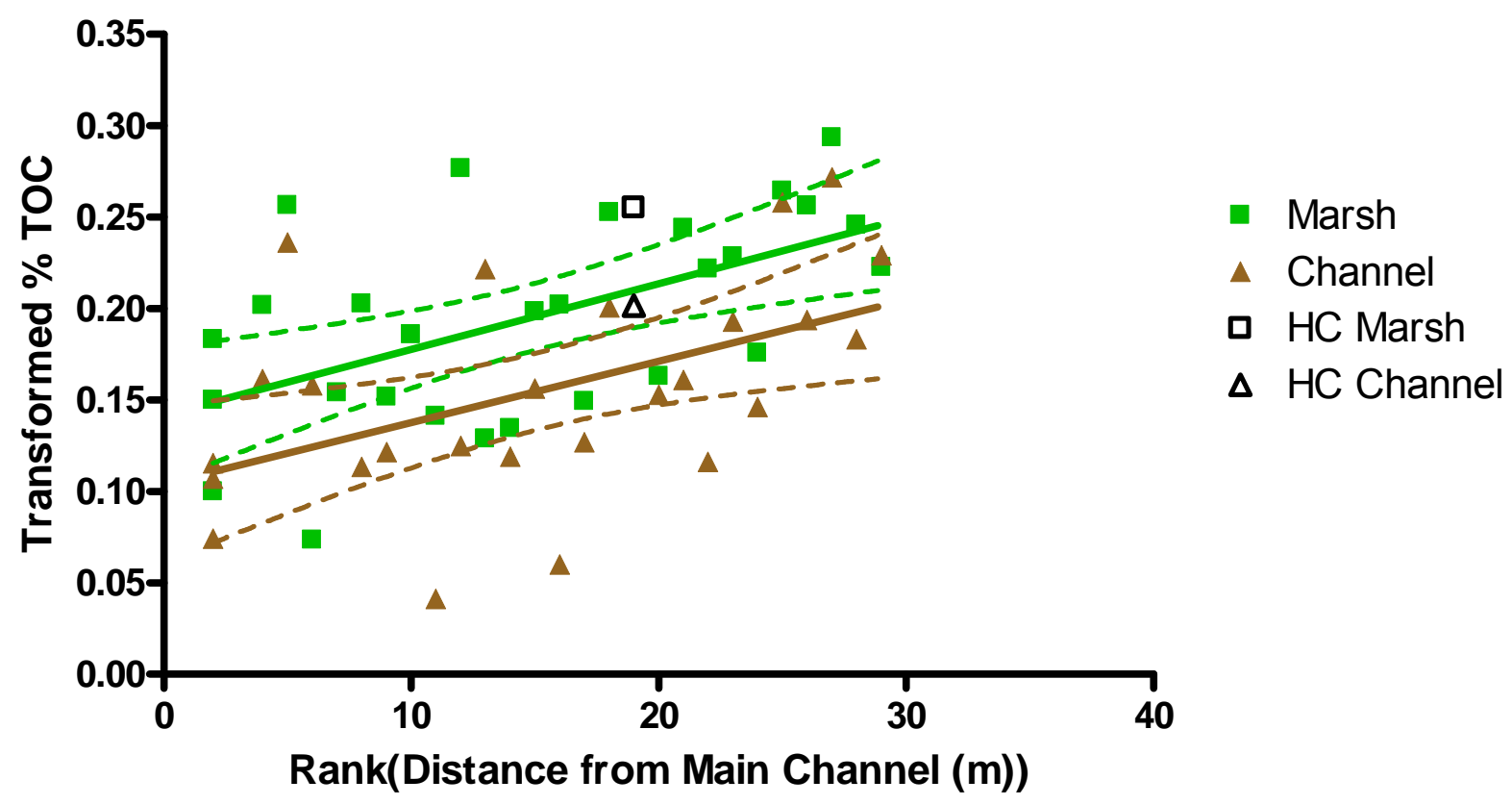

Figure 3.6. Percent total organic carbon and ranked distance from the main channel, for marsh and tributary marsh floodplain soils (top panel) and channel sediments (bottom panel).

\section{Sediment Grain Size, Total Organic Carbon, and Wetland Type}

Descriptive statistics of sediment characteristics were calculated for each wetland type, on the floodplain (Table 3.4) and in the channels, typically near the bank because of standing water in the thalweg (Table 3.5). In the interpretation of these tables, it should be noted that all swamp, riparian, and shrub-scrub sites are disturbance category 0 .

Measurements taken within different wetland types $(n=41)$ and the marsh channel were compared using the nonparametric Kruskal-Wallis test. (TOC was not significantly different between plant strata $(\mathrm{p}=0.43))$. The percent gravel was nearly significant $(\mathrm{p}=0.06)$ between plant strata with PHAR tending to be associated with areas having greater percent gravel. The percent fines and sand were both significantly different between strata $(\mathrm{p}<0.004)$ with wapato (Sagittaria latifolia [SALA]) located within greater percent fines and ELPA within greater sand sediments. For marshes only, TOC (\%) was significantly greater in the marsh than in the channel $(\mathrm{p}=0.01)$, and the channels had significantly greater percent sand $(\mathrm{p}=0.03)$. TOC measurements taken within the floodplain or from the channel of forested wetlands (riparian and swamp), tributary swamps, and shrub sites were not significantly different (Kruskal-Wallis, $\mathrm{p}=0.72$ and $\mathrm{p}=0.36$, respectively). Grain size measurements taken on the floodplain within forested sites tended to have a greater percentage of sand and shrub sites tended to have a greater percentage fines but neither was found to be statistically significant $(\mathrm{p}>0.07)$. Grain size measurements taken from the channel were not significantly different between forested and shrub sites (Kruskal-Wallis, $\mathrm{p}>0.12)$. 
Table 3.4. Descriptive statistics of floodplain sediment characteristics by wetland type and location within site (mean, range, and sample size).

\begin{tabular}{ccccccc}
\hline & & Tributary & & & Tributary & \\
Variable & Marsh & Marsh & Riparian & Swamp & Swamp & Shrub/Scrub \\
\hline Yearly Accretion/ & 0.49 & 1.37 & 0.84 & 0.24 & 0.38 & 0.93 \\
Erosion Rate $\left(\mathrm{cm}^{2}\right)$ & $-7.76-3.69$ & $-0.13-2.55$ & $0.84-0.84$ & $0.04-0.43$ & $0.38-0.38$ & $-0.96-2.82$ \\
& $\mathrm{n}=30$ & $\mathrm{n}=4$ & $\mathrm{n}=1$ & $\mathrm{n}=3$ & $\mathrm{n}=1$ & $\mathrm{n}=2$ \\
TOC & 4.10 & 5.40 & 4.22 & 4.53 & 5.54 & 5.51 \\
$(\%)$ & $0.22-9.68$ & $4.88-5.92$ & $4.14-4.29$ & $2.21-7.91$ & $5.54-5.54$ & $4.13-6.89$ \\
& $\mathrm{n}=68$ & $\mathrm{n}=2$ & $\mathrm{n}=2$ & $\mathrm{n}=3$ & $\mathrm{n}=1$ & $\mathrm{n}=2$ \\
Gravel & 3.2 & 1.1 & 0.4 & 14.3 & 1.3 & 0.9 \\
$(\%)$ & $0.0-48.9$ & $0.7-1.4$ & $0.2-0.5$ & $9.3-19.4$ & $1.3-1.3$ & $0.2-1.7$ \\
& $\mathrm{n}=68$ & $\mathrm{n}=2$ & $\mathrm{n}=2$ & $\mathrm{n}=3$ & $\mathrm{n}=1$ & $\mathrm{n}=2$ \\
Sand (\%) & 32.0 & 23.3 & 41.2 & 38.9 & 19.6 & 17.4 \\
& $1.2-97.7$ & $20.7-25.9$ & $22.2-60.2$ & $35.1-42.7$ & $19.6-19.6$ & $16.8-18.1$ \\
& $\mathrm{n}=68$ & $\mathrm{n}=2$ & $\mathrm{n}=2$ & $\mathrm{n}=3$ & $\mathrm{n}=1$ & $\mathrm{n}=2$ \\
Fines (\%) & 64.8 & 75.6 & 53.9 & 49.2 & 83.3 & 83.1 \\
& $1.1-98.5$ & $72.7-78.6$ & $36.6-71.2$ & $45.0-53.4$ & $83.3-83.3$ & $79.7-86.4$ \\
& $\mathrm{n}=68$ & $\mathrm{n}=2$ & $\mathrm{n}=2$ & $\mathrm{n}=3$ & $\mathrm{n}=1$ & $\mathrm{n}=2$ \\
\hline
\end{tabular}

Table 3.5. Descriptive statistics of channel sediment characteristics by wetland type and location within site (mean, range, and sample size).

\begin{tabular}{|c|c|c|c|c|c|c|}
\hline \multirow[b]{3}{*}{ Variable } & \multicolumn{3}{|c|}{ Tributary } & \multicolumn{3}{|c|}{ Tributary } \\
\hline & Marsh & Marsh & Riparian & Swamp & Swamp & Shrub/Scrub \\
\hline & Channel & Channel & Channel & Channel & Channel & Channel \\
\hline TOC & 2.75 & 4.24 & 1.84 & 3.64 & 3.02 & 1.76 \\
\hline \multirow[t]{2}{*}{$(\%)$} & $0.17-7.31$ & $3.32-5.16$ & $0.63-3.05$ & $3.21-3.92$ & $3.02-3.02$ & $1.70-1.82$ \\
\hline & $\mathrm{n}=28$ & $\mathrm{n}=2$ & $\mathrm{n}=2$ & $\mathrm{n}=3$ & $\mathrm{n}=1$ & $\mathrm{n}=2$ \\
\hline \multirow{3}{*}{$\begin{array}{c}\text { Gravel } \\
(\%)\end{array}$} & 2.5 & 0.1 & 0.5 & 1.4 & 32.7 & 0.2 \\
\hline & $0.0-57.1$ & $0.0-0.2$ & $0.0-0.9$ & $1.1-1.6$ & $32.7-32.7$ & $0.0-0.5 \mathrm{n}=2$ \\
\hline & $\mathrm{n}=28$ & $\mathrm{n}=2$ & $\mathrm{n}=2$ & $\mathrm{n}=3$ & $\mathrm{n}=1$ & \\
\hline \multirow[t]{3}{*}{ Sand (\%) } & 44.1 & 22.1 & 37.9 & 24.9 & 30.8 & 44.1 \\
\hline & $6.3-94.6$ & $19.0-25.1$ & $29.0-46.7$ & $14.9-36.1$ & $30.8-30.8$ & $22.7-65.4$ \\
\hline & $\mathrm{n}=28$ & $\mathrm{n}=2$ & $\mathrm{n}=2$ & $\mathrm{n}=3$ & $\mathrm{n}=1$ & $\mathrm{n}=2$ \\
\hline \multirow[t]{3}{*}{ Fines $(\%)$} & 53.5 & 77.8 & 57.8 & 76.1 & 39.6 & 54.8 \\
\hline & $1.3-93.7$ & $74.6-81.0$ & $49.6-66.0$ & $67.6-87.0$ & $39.6-39.6$ & $33.0-76.6$ \\
\hline & $\mathrm{n}=28$ & $\mathrm{n}=2$ & $\mathrm{n}=2$ & $\mathrm{n}=3$ & $\mathrm{n}=1$ & $\mathrm{n}=2$ \\
\hline
\end{tabular}

\section{Sediment Grain Size, Total Organic Carbon, and Distance from Main Channel}

Regression analyses indicate that the following characteristics of soils and sediments (transformed to the arcsine square root) have significant relationships to the ranked distance of the site from the main channel of the Columbia River: average percent sand in marsh ("marsh" indicates cores taken on the floodplain, not in the channel) $(\mathrm{p}=0.0118)$; average percent fines in marsh $(\mathrm{p}=0.037)$; average percent sand in channels $(p=0.0114)$; and average percent fines in channels $(p=0.0129)$. Thus, the percent sand and percent fines are perhaps better explained by distance from the main channel, location near the dam, and other local factors - as opposed to site disturbance code (Figure 3.7). The intercepts of the regression of percent sand as a function of the distance to the main channel were significantly different between samples collected on the floodplain and within the channel (Regression, $p=0.01$ ), but the slopes were not 
significantly different $(p=0.33)$. Similarly, the differences between the intercepts for the percent fines collected from the floodplain and channel were also significantly different $(p=0.02)$, however the slopes were not $(p=0.23)$. The five highest percentages of sand and fines, aside from the dredged material placement sites, have the following characteristics:

- SIM - This is the last active dune area on the lower Columbia River according to Christy and Putera (1993).

- PIM - Located in the main channel just downstream from the dam and presumably experiences very high flows.

- RIM - The site has one area (veg strata Carex obnupta [CAOB]) that was very sandy, at the mouth of the channel, which may have elevated the percentage.

- WRM - This is an island in the Washougal River delta and likely experiences high flow.

- HCM - This site is located along a perennial stream and may be affected by its processes.
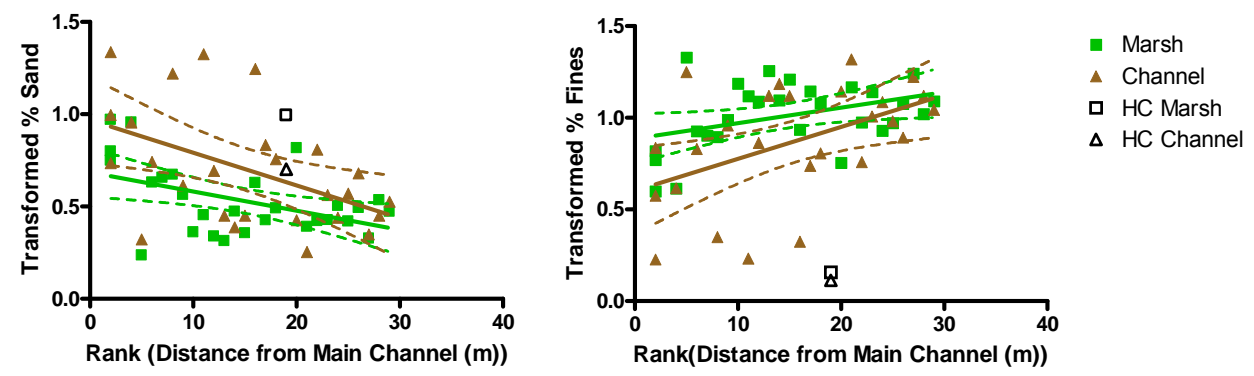

Figure 3.7. Percent sand and fines in marsh and channel sediments at sites with ranked distance from the main channel. $(\mathrm{HC}=$ Hardy Creek)

\section{Channel Morphology}

Summary analyses of channel morphology were previously presented for each wetland type and emergent marsh zone in Section 1, Table 17 and Figure 16. In Section 1, we found that for the most part, statistical tests did not distinguish metrics of channel morphology by EM zone or wetland type. The only statistically significant difference was in the width-to-depth ratio (Kruskal-Wallis: $n=35, p=0.002$ ), and this result was driven by the difference between tributaries and all other EM zones.

In further analyses of channels related to disturbance categories, reported herein, we have evaluated characteristics of channels including bank elevation, thalweg elevation, depth, cross-sectional area, width, and width-to-depth ratio (Table 3.6). Nine sites are not included in this table because they did not have channels or data were not collected. Because channel morphological attributes such as these are associated with flows (Leopold and Maddock 1953; Williams et al. 2002), they may be viewed as one proxy for connectivity. The thalweg is defined as the lowest point in the channel bed, and the difference from the channel bank is termed "depth". Cross-sectional area and channel top width are also given.

Data for channel morphological characteristics are reported according to the level-of-disturbance categories (Table 3.7, Table 3.8). Several features of morphology are significantly different by disturbance category - thalweg elevation, depth, cross-sectional area, and width-to-depth ratio - and bank elevation and width are nearly significant; however, channel morphological characteristics did not significantly differ by distance from the main channel of the Columbia River (Table 3.9). 
Table 3.6. Channel and floodplain characteristics. Elevations are reported in the Columbia River Datum with two exceptions: sites below Rkm 36 are reported in mean lower low water and sites located on tributaries are reported in NAVD88.

\begin{tabular}{|c|c|c|c|c|c|c|c|c|c|c|c|}
\hline $\begin{array}{c}\text { Site } \\
\text { Disturbance } \\
\text { Code }\end{array}$ & $\begin{array}{l}\text { Site } \\
\text { Code }\end{array}$ & Type & rkm & $\begin{array}{c}\text { Channel } \\
\mathrm{y} / \mathrm{n}\end{array}$ & $\begin{array}{c}\text { Bank } \\
\text { Elevation } \\
\text { (m) }\end{array}$ & $\begin{array}{c}\text { Thalweg } \\
\text { Elevation (m) }\end{array}$ & $\begin{array}{c}\text { Channel } \\
\text { Depth (m) }\end{array}$ & $\begin{array}{c}\text { Cross- } \\
\text { Section } \\
\text { Area }\left(\mathrm{m}^{2}\right)\end{array}$ & $\begin{array}{c}\text { Channel } \\
\text { Width (m) }\end{array}$ & $\begin{array}{c}\text { Width:Depth } \\
\text { Ratio }\end{array}$ & $\begin{array}{l}\text { Avg. Site } \\
\text { Elevation }\end{array}$ \\
\hline 0 & SRM & Marsh & 37 & yes & 1.33 & 0.27 & 1.06 & 18.42 & 22.54 & 21.26 & 1.99 \\
\hline 1 & WIM & Marsh & 53 & yes & 1.90 & -0.03 & 1.93 & 37.05 & 24.79 & 12.88 & 2.35 \\
\hline 1 & RIM & Marsh & 61 & yes & 1.93 & 0.21 & 1.72 & 36.64 & 36.54 & 21.30 & 1.93 \\
\hline 1 & BIM & Marsh & 131 & yes & 0.53 & 0.09 & 0.44 & 4.65 & 17.67 & 40.08 & 1.18 \\
\hline 1 & SBM & Marsh & 143 & yes & 0.90 & 0.32 & 0.57 & 2.56 & 7.42 & 12.93 & 1.33 \\
\hline 1 & SIM & Marsh & 211 & yes & 0.70 & 0.55 & 0.15 & 0.26 & 1.69 & 11.06 & 1.13 \\
\hline 1 & FLM & Marsh & 221 & yes & 2.52 & 0.15 & 2.37 & 36.17 & 32.01 & 13.51 & 1.93 \\
\hline 1 & PIM & Marsh & 228 & yes & 1.59 & 0.71 & 0.88 & 7.60 & 20.32 & 23.14 & 1.59 \\
\hline 2 & BBM & Marsh & 6 & yes & 1.59 & 0.90 & 0.68 & 3.54 & 6.34 & 9.30 & 2.00 \\
\hline 2 & CHM & Marsh & 12 & yes & 1.03 & 0.65 & 0.38 & 2.54 & 13.37 & 34.91 & 2.14 \\
\hline 2 & TBB & Marsh & 12 & yes & 1.70 & 0.56 & 1.14 & 21.20 & 30.89 & 27.22 & 2.32 \\
\hline 2 & LCM & Marsh & 20 & yes & 1.36 & 0.50 & 0.85 & 7.40 & 18.32 & 21.45 & 2.32 \\
\hline 2 & CRM & Marsh & 80 & yes & 2.14 & 0.69 & 1.46 & 12.90 & 15.19 & 10.43 & 1.98 \\
\hline 2 & CS1 & Marsh & 149 & yes & 2.01 & 0.89 & 1.12 & 33.94 & 43.04 & 38.49 & 1.67 \\
\hline 2 & OSM & Marsh & 198 & yes & 1.65 & 0.72 & 0.93 & 4.67 & 10.71 & 11.49 & 1.64 \\
\hline 3 & KIB & Marsh & 41 & yes & 1.91 & -2.33 & 4.24 & 91.26 & 41.75 & 9.84 & 1.67 \\
\hline 4 & MSC & Marsh & 39 & yes & 0.95 & 0.69 & 0.27 & 1.45 & 8.73 & 32.45 & 1.24 \\
\hline 4 & $\mathrm{JIC}$ & Marsh & 71 & yes & 0.84 & 0.43 & 0.41 & 9.60 & 47.74 & 115.87 & 1.33 \\
\hline 4 & WHC & Marsh & 72 & yes & 1.51 & 0.46 & 1.05 & 21.76 & 39.48 & 37.64 & 1.90 \\
\hline 4 & WAC & Marsh & 77 & yes & 1.83 & 0.67 & 1.16 & 51.25 & 72.11 & 62.21 & 1.53 \\
\hline 4 & GUC & Marsh & 89 & yes & 1.41 & 0.80 & 0.61 & 6.75 & 16.64 & 27.41 & 1.80 \\
\hline 4 & LI1 & Marsh & 99 & yes & 2.51 & -0.44 & 2.94 & 46.96 & 29.44 & 10.00 & 2.33 \\
\hline
\end{tabular}


Table 3.6. (contd)

\begin{tabular}{|c|c|c|c|c|c|c|c|c|c|c|c|}
\hline $\begin{array}{c}\text { Site } \\
\text { Disturbance } \\
\text { Code }\end{array}$ & $\begin{array}{l}\text { Site } \\
\text { Code }\end{array}$ & Type & $\mathrm{rkm}$ & $\begin{array}{c}\text { Channel } \\
\mathrm{y} / \mathrm{n}\end{array}$ & $\begin{array}{c}\text { Bank } \\
\text { Elevation } \\
(\mathrm{m})\end{array}$ & $\begin{array}{l}\text { Thalweg } \\
\text { Elevation } \\
(\mathrm{m})\end{array}$ & $\begin{array}{l}\text { Channel } \\
\text { Depth (m) }\end{array}$ & $\begin{array}{c}\text { Cross- } \\
\text { Section } \\
\text { Area }\left(\mathrm{m}^{2}\right)\end{array}$ & $\begin{array}{c}\text { Channel } \\
\text { Width } \\
\text { (m) }\end{array}$ & $\begin{array}{c}\text { Width:Dept } \\
\text { h Ratio }\end{array}$ & $\begin{array}{c}\text { Avg. Site } \\
\text { Elevatio } \\
n\end{array}$ \\
\hline 4 & LI2 & Marsh & 100 & yes & 1.15 & 0.99 & 0.17 & 1.09 & 13.14 & 79.14 & 1.47 \\
\hline 4 & CI1 & Marsh & 113 & yes & 0.88 & -0.83 & 1.71 & 26.66 & 72.98 & 42.75 & 1.40 \\
\hline 4 & $\mathrm{CI} 2$ & Marsh & 114 & yes & 0.61 & 0.44 & 0.17 & 1.92 & 63.67 & 374.51 & 0.98 \\
\hline 4 & SI1 & Marsh & 121 & yes & 1.20 & 0.46 & 0.74 & 16.01 & 33.28 & 44.74 & 1.13 \\
\hline 4 & SI2 & Marsh & 123 & yes & 1.31 & 0.89 & 0.42 & 2.65 & 6.00 & 14.42 & 1.27 \\
\hline 4 & GIC & Marsh & 131 & yes & 1.39 & 0.53 & 0.85 & 48.65 & 81.38 & 95.29 & 1.54 \\
\hline 4 & DIC & Marsh & 132 & yes & 1.84 & 0.66 & 1.18 & 43.36 & 68.59 & 58.13 & 1.51 \\
\hline 4 & SSC & Marsh & 154 & yes & 1.03 & 0.72 & 0.31 & 19.36 & 107.23 & 342.59 & 1.55 \\
\hline 5 & VS & Marsh & 19 & yes & 1.88 & -2.22 & 4.10 & 51.96 & 23.71 & 5.78 & 0.96 \\
\hline 5 & $\mathrm{CI}$ & Marsh & 90 & yes & 2.68 & -0.65 & 3.34 & 46.04 & 50.88 & 15.26 & 1.73 \\
\hline NA & $\mathrm{HC}$ & Marsh & 230 & yes & 0.80 & -0.25 & 1.05 & 9.10 & 11.93 & 11.32 & 3.31 \\
\hline 0 & GIM & Marsh-Tributary & 23 & yes & 0.93 & 0.41 & 0.51 & 1.00 & 3.24 & 6.30 & 2.25 \\
\hline 3 & FCB & Marsh-Tributary & 19 & yes & 2.11 & -0.17 & 2.28 & 21.36 & 19.92 & 8.74 & 2.62 \\
\hline 3 & HIB & Marsh-Tributary & 23 & yes & 2.31 & -1.29 & 3.59 & 54.46 & 26.05 & 7.26 & 2.07 \\
\hline 5 & $\mathrm{KF}$ & Marsh-Tributary & 37 & yes & 2.04 & -2.80 & 4.84 & 87.98 & 32.78 & 6.78 & 1.97 \\
\hline NA & CSM & Marsh-Tributary & 23 & yes & 2.57 & -0.31 & 2.88 & 24.27 & 13.86 & 4.81 & 2.48 \\
\hline 0 & $\mathrm{CCS}$ & Forested & 37 & yes & 2.16 & -0.58 & 2.74 & 31.40 & 18.00 & 6.57 & 3.02 \\
\hline 0 & SRS & Forested & 37 & yes & 2.42 & 0.36 & 2.07 & 19.09 & 14.10 & 6.82 & 2.91 \\
\hline 0 & KIS & Forested & 40 & yes & 2.18 & -0.65 & 2.83 & 38.00 & 20.95 & 7.42 & 2.63 \\
\hline 0 & CCR & Forested & 98 & yes & 2.86 & -2.31 & 5.17 & 151.06 & 39.11 & 7.57 & 2.68 \\
\hline 0 & GCR & Forested & 141 & yes & 2.76 & 0.65 & 2.11 & 48.56 & 29.40 & 13.93 & 3.82 \\
\hline 0 & SSS & Forested-Tributary & 37 & yes & 2.20 & 0.05 & 2.16 & 17.93 & 11.85 & 5.50 & 2.80 \\
\hline 0 & WIS & Shrub & 53 & yes & 1.90 & -0.03 & 1.93 & 37.05 & 24.79 & 12.88 & 2.27 \\
\hline 0 & WSS & Shrub & 73 & yes & 2.29 & -4.54 & 6.83 & 136.80 & 31.28 & 4.58 & 2.44 \\
\hline
\end{tabular}


Table 3.7. Channel morphology and floodplain characteristics (mean, range, and sample size) for marshes.

\begin{tabular}{|c|c|c|c|c|c|c|c|c|}
\hline \multirow[b]{2}{*}{ Type } & \multirow[b]{2}{*}{ Variable } & \multicolumn{7}{|c|}{ Site Disturbance Code } \\
\hline & & 0 & 1 & 2 & 3 & 4 & 5 & NA \\
\hline \multirow[t]{24}{*}{ Marsh } & Bank Elevation & 1.33 & 1.4 & 1.6 & 1.91 & 1.3 & 2.3 & 0.80 \\
\hline & $(\mathrm{m})$ & & $0.5-2.5$ & $1.0-2.1$ & & $0.6-2.5$ & $1.9-2.7$ & \\
\hline & & & $\mathrm{n}=7$ & $\mathrm{n}=7$ & & $\mathrm{n}=14$ & $\mathrm{n}=2$ & \\
\hline & Thalweg & 0.27 & 0.3 & 0.7 & -2.33 & 0.5 & -1.4 & -0.25 \\
\hline & Elevation (m) & & $0.0-0.7$ & $0.5-0.9$ & & $-0.8-1.0$ & $-2.2--0.7$ & \\
\hline & & & $\mathrm{n}=7$ & $\mathrm{n}=7$ & & $\mathrm{n}=14$ & $\mathrm{n}=2$ & \\
\hline & Channel Depth & 1.06 & 1.2 & 0.9 & 4.24 & 0.9 & 3.7 & 1.05 \\
\hline & & & $0.2-2.4$ & $0.4-1.5$ & & $0.2-2.9$ & $3.3-4.1$ & \\
\hline & & & $\mathrm{n}=7$ & $\mathrm{n}=7$ & & $\mathrm{n}=14$ & $\mathrm{n}=2$ & \\
\hline & Cross-Section & 18.42 & 17.8 & 12.3 & 91.26 & 21.2 & 49.0 & 9.10 \\
\hline & Area $\left(\mathrm{m}^{2}\right)$ & & $0.3-37.1$ & $2.5-33.9$ & & $1.1-51.3$ & $46.0-52.0$ & \\
\hline & & & $\mathrm{n}=7$ & $\mathrm{n}=7$ & & $\mathrm{n}=14$ & $\mathrm{n}=2$ & \\
\hline & Channel Width & 22.54 & 20.1 & 19.7 & 41.75 & 47.2 & 37.3 & 11.93 \\
\hline & $(\mathrm{m})$ & & $1.7-36.5$ & $6.3-43.0$ & & $6.0-107.2$ & $23.7-50.9$ & \\
\hline & & & $\mathrm{n}=7$ & $\mathrm{n}=7$ & & $\mathrm{n}=14$ & $\mathrm{n}=2$ & \\
\hline & Width:Depth & 21.26 & 19.3 & 21.9 & 9.84 & 95.5 & 10.5 & 11.32 \\
\hline & Ratio & & $11.1-40.1$ & $9.3-38.5$ & & $10.0-374.5$ & $5.8-15.3$ & \\
\hline & & & $\mathrm{n}=7$ & $\mathrm{n}=7$ & & $\mathrm{n}=14$ & $\mathrm{n}=2$ & \\
\hline & Proportion & 1.00 & 0.5 & 0.2 & 0.20 & 0.6 & $\mathrm{n}=0$ & 0.00 \\
\hline & Low Marsh & & $0.0-0.9$ & $0.0-0.6$ & & $0.2-1.0$ & & \\
\hline & & & $\mathrm{n}=9$ & $\mathrm{n}=9$ & & $\mathrm{n}=19$ & & \\
\hline & Average & 1.99 & 1.6 & 2.0 & 1.67 & 1.5 & 1.3 & 3.31 \\
\hline & Site Elevation & & $1.1-2.4$ & $1.6-2.3$ & & $1.0-2.3$ & $1.0-1.7$ & \\
\hline & & & $\mathrm{n}=9$ & $\mathrm{n}=9$ & & $\mathrm{n}=19$ & $\mathrm{n}=2$ & \\
\hline \multirow{19}{*}{$\begin{array}{l}\text { Marsh- } \\
\text { Tributary }\end{array}$} & Bank Elevation & 0.93 & $\mathrm{n}=0$ & $\mathrm{n}=0$ & 2.2 & $n=0$ & 2.04 & 2.57 \\
\hline & & & & & $\begin{array}{c}2.1-2.3 \\
n=2\end{array}$ & & & \\
\hline & Thalweg & 0.41 & $\mathrm{n}=0$ & $\mathrm{n}=0$ & -0.7 & $\mathrm{n}=0$ & -2.80 & -0.31 \\
\hline & Elevation (m) & & & & $\begin{array}{c}-1.3--0.2 \\
n=2\end{array}$ & & & \\
\hline & Channel Depth & 0.51 & $\mathrm{n}=0$ & $\mathrm{n}=0$ & 2.9 & $\mathrm{n}=0$ & 4.84 & 2.88 \\
\hline & $(\mathrm{m})$ & & & & $\begin{array}{c}2.3-3.6 \\
n=2\end{array}$ & & & \\
\hline & Cross-Section & 1.00 & $\mathrm{n}=0$ & $\mathrm{n}=0$ & 37.9 & $\mathrm{n}=0$ & 87.98 & 24.27 \\
\hline & Area $\left(\mathrm{m}^{2}\right)$ & & & & $\begin{array}{c}21.4-54.5 \\
n=?\end{array}$ & & & \\
\hline & Channel Width & 3.24 & $\mathrm{n}=0$ & $\mathrm{n}=0$ & 23.0 & $\mathrm{n}=0$ & 32.78 & 13.86 \\
\hline & (m) & & & & $\begin{array}{c}19.9-26.0 \\
n=2\end{array}$ & & & \\
\hline & Width:Depth & 6.30 & $\mathrm{n}=0$ & $\mathrm{n}=0$ & 8.0 & $\mathrm{n}=0$ & 6.78 & 4.81 \\
\hline & Ratio & & & & $7.3-8.7$ & & & \\
\hline & & & & & $\mathrm{n}=2$ & & & \\
\hline & Proportion & 0.30 & $\mathrm{n}=0$ & $\mathrm{n}=0$ & 0.2 & $\mathrm{n}=0$ & $\mathrm{n}=0$ & 0.00 \\
\hline & Low Marsh & & & & $0.1-0.3$ & & & \\
\hline & & & & & $\mathrm{n}=2$ & & & \\
\hline & Average & 2.25 & $\mathrm{n}=0$ & $\mathrm{n}=0$ & 2.3 & $\mathrm{n}=0$ & 1.97 & 2.48 \\
\hline & Site Elevation & & & & $2.1-2.6$ & & & \\
\hline & & & & & $\mathrm{n}=2$ & & & \\
\hline
\end{tabular}


Table 3.8. Channel morphology and floodplain characteristics (mean, range, and sample size) for forested and shrub wetlands. All disturbance code $=0$.

\begin{tabular}{cccc}
\hline Variable & $\begin{array}{c}\text { Forested } \\
\mathrm{n}=5\end{array}$ & $\begin{array}{c}\text { Forested-Tributary } \\
\mathrm{n}=1\end{array}$ & $\begin{array}{c}\text { Shrub } \\
\mathrm{n}=2\end{array}$ \\
\hline Bank Elevation & 2.5 & 2.20 & 2.1 \\
(m, CRD) & $2.2-2.9$ & & $1.9-2.3$ \\
Thalweg Elevation & -0.6 & 0.05 & -2.3 \\
(m, CRD) & $-2.3-0.7$ & & $-4.5-0.0$ \\
Channel Depth & 3.1 & 2.16 & 4.4 \\
(m) & $2.1-5.2$ & & $1.9-6.8$ \\
Cross-Section Area & 59.6 & 17.93 & 86.9 \\
( $^{2}$ ) & $29.1-151.1$ & & $37.1-136.8$ \\
Channel Width & 25.3 & 11.85 & 28.0 \\
(m) & $18.0-39.1$ & & $24.8-31.3$ \\
Width:Depth Ratio & 8.4 & 5.50 & 8.7 \\
& $6.6-13.9$ & & $4.6-12.9$ \\
Average Site Elevation & 3.0 & 2.80 & 2.4 \\
(m, CRD) & $2.6-3.8$ & & $2.3-2.4$ \\
\hline
\end{tabular}

Table 3.9. Kruskal-Wallis test of equal medians by disturbance level and regression test of slope equal to zero for all marshes (main stem and tributary; main stem only for bank and thalweg elevations, proportion low marsh, and site elevation).

\begin{tabular}{ccc}
\hline Variable & $\begin{array}{c}\text { Kruskal-Wallis Test } \\
\text { by Disturbance Level ( } \mathrm{p} \text {-value) }\end{array}$ & $\begin{array}{c}\text { Significance of Slope } \\
\text { by Rank Distance (p-value) }\end{array}$ \\
\hline Bank Elevation $(\mathrm{m})$ & $\mathrm{p}=0.21$ & $\mathrm{p}=0.39$ \\
Thalweg Elevation $(\mathrm{m})$ & $\mathrm{P}=0.02$ & $\mathrm{p}=0.41$ \\
Channel Depth $(\mathrm{m})$ & $\mathrm{p}=0.01$ & $\mathrm{p}=0.08$ \\
Cross-Section Area $\left(\mathrm{m}^{2}\right)$ & $\mathrm{p}=0.056$ & $\mathrm{p}=0.40$ \\
Channel Width $(\mathrm{m})$ & $\mathrm{p}=0.13$ & $\mathrm{p}=0.16$ \\
Width:Depth Ratio & $\mathrm{p}<0.01$ & $\mathrm{p}=0.27$ \\
Low Marsh & $\mathrm{p}=0.023$ & $\mathrm{p}=0.52$ \\
Site Elevation & $\mathrm{p}<0.01$ & $\mathrm{p}=0.10$ \\
\hline
\end{tabular}

In general, higher the bank elevations observed at historically breached and newly restored sites are higher than those in other categories, which may in part be explained by the location of some of these sites on tributaries (3 of 6 sites) or in EM1, with its high tidal influence, although other sites in EM1 (GIM and SRM) do not exhibit this characteristic. The tributary sites may be higher because of the rise of the river, or because of analytical methods which use the CRD datum for main-stem river sites and NAVD88 for tributaries. Bank elevations of $2.98 \mathrm{~m}, \mathrm{CRD}$ at Crims Island (CI), where channels were excavated, are the highest of any site sampled (Table 3.6.).

The lowest thalweg elevations are also observed at the historically breached (median $-1.29 \mathrm{~m}, \mathrm{CRD}$ ) and newly restored (median $-2.22 \mathrm{~m}, \mathrm{CRD}$ ) sites, meaning that given the higher bank elevations channel depth is also greatest at these sites. (These medians, and Figure 7, include one recently reconnected and two previously diked sites with elevations reported in NAVD88, not CRD.) Since subsidence typically occurs behind dikes, the tidal prism after hydrologic reconnection may be greater than historical, so 
channels may need to be larger to convey flows (Diefenderfer et al. 2008). In contrast, significantly higher thalweg elevation are generally seen at sites that have been affected by local disturbances (median 0.67 ) and dredged material placement (median 0.60) (Kruskal-Wallis, $p=0.02$ ), which could have implications for fish access to the wetland channels, particularly at low water levels (low tides and/or low river flows) (Figure 3.8). The median depth of dredged material placement sites $(0.68 \mathrm{~m})$ is significantly shallower than historically breached $(3.59 \mathrm{~m})$ and newly restored $(4.10)$ sites (Kruskal-Wallis $\mathrm{p}=0.01)$.

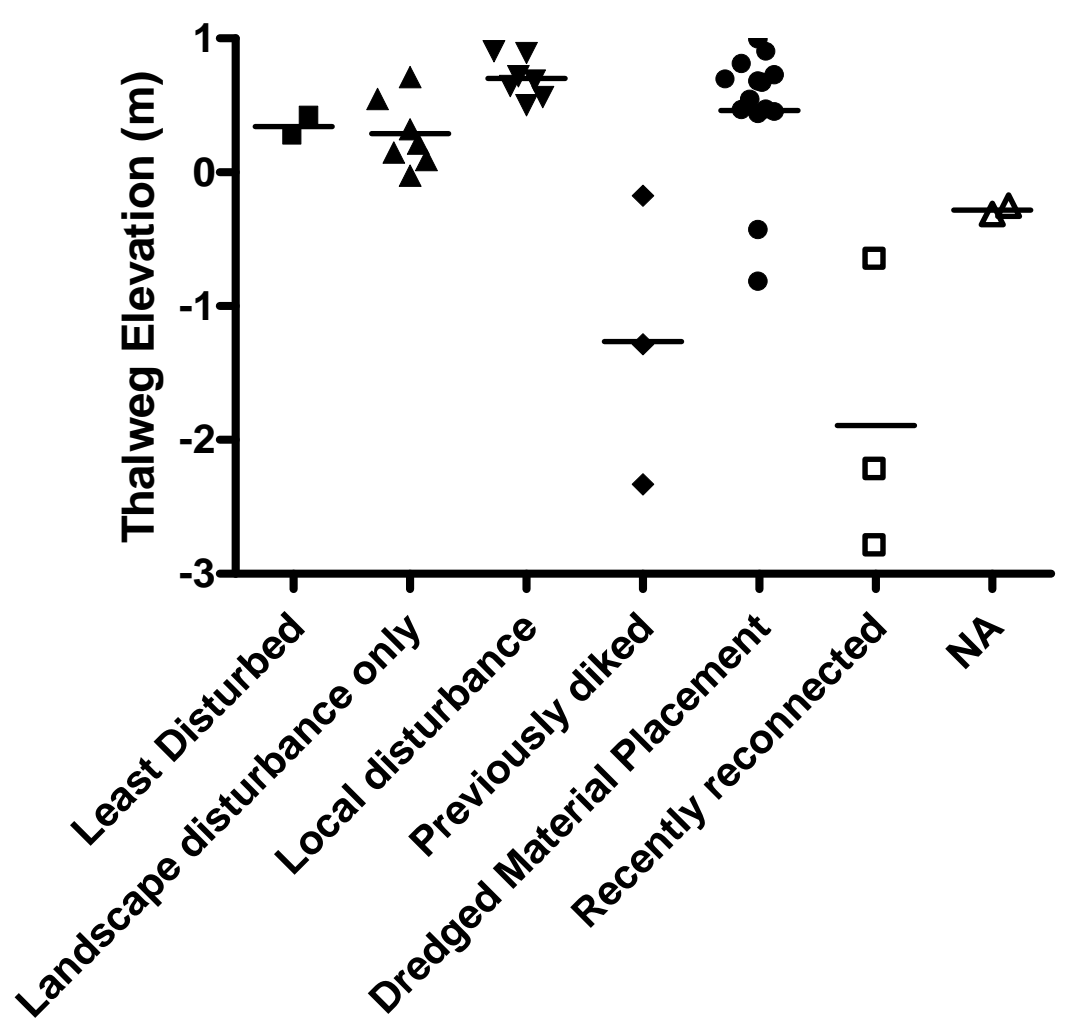

Figure 3.8. Thalweg elevations of marsh channels surveyed at the mouth.

The median cross-sectional area of previously diked and recently connected sites was nearly significantly greater than all other disturbance categories (Figure 3.9). The observed variability in crosssectional area between marshes was not explained by the distance to the main channel.

The median width-to-depth ratio of channels at sites with dredged material placement (a nondimensional number, 51.4) is significantly higher than at previously diked sites (8.7) (Kruskal-Wallis, $\mathrm{p}=0.001$ ). In fact, it is higher than the medians of all other disturbance categories (Figure 3.9). This morphology, with a wide top width and shallow depth, may have implications for surface water warming effects on water temperature in the channels and, in turn, fish habitat capacity. However, preliminary tests of several water temperature metrics were not significant relative to disturbance history; for example, the median of the 7-DADMAX (General Linear Model with year and distance from the main stem as covariates, $\mathrm{p}=0.19$ ). Nine of the dredged material placement sites have a greater width-to-depth ratio than any other sites sampled. 

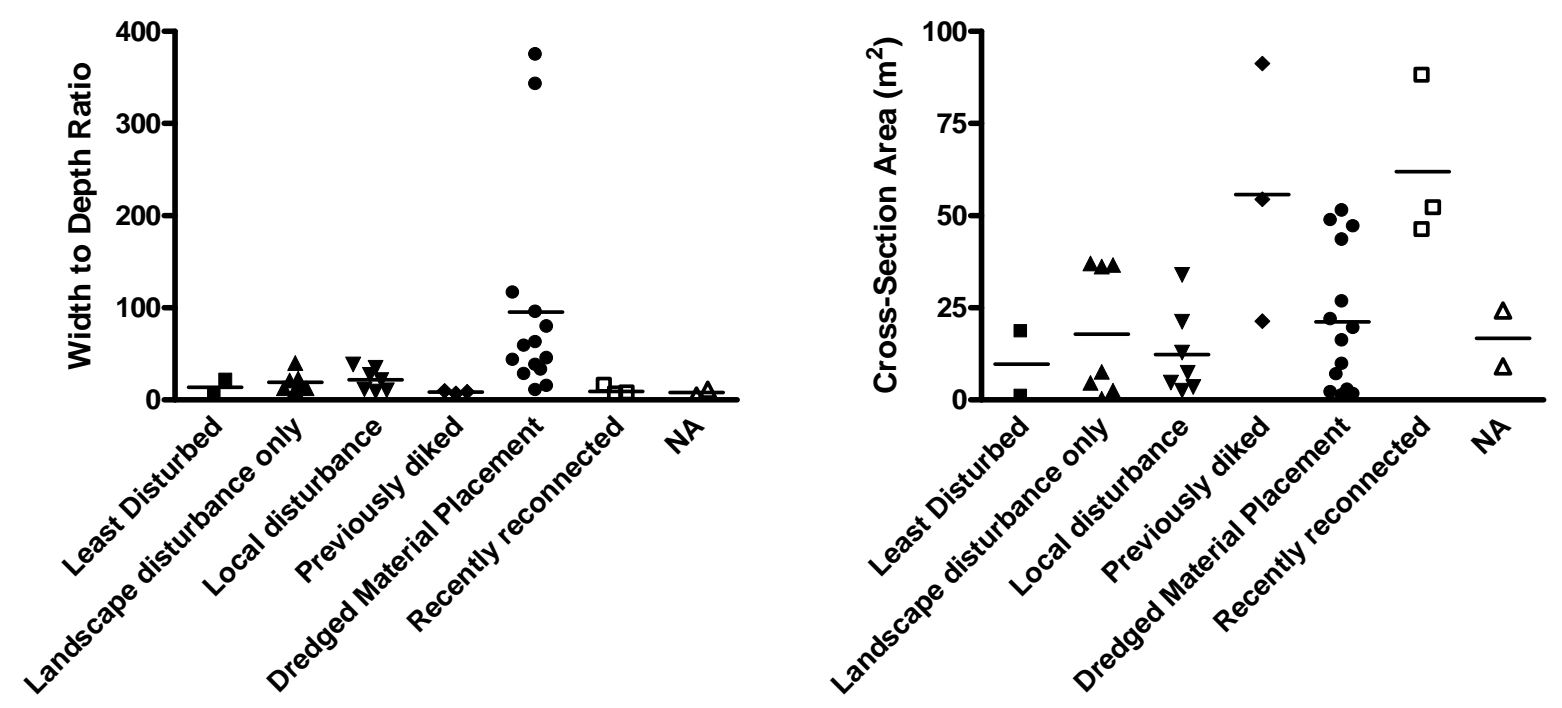

Figure 3.9. Width-to-depth ratio and cross-sectional area of marsh channels surveyed at the mouth.

\subsubsection{Plant Community Characteristics}

We evaluated site disturbance level relative to plant community characteristics including average absolute percent reed canarygrass, number of native species, total number of species (species richness), average number of species per quadrat, average cover of native species, and the ratio of reed canarygrass to other non-native plant cover (Table 3.10). The average number of species per quadrat in locally disturbed sites, a measure of patchiness for this application, was significantly different from that in all other level-of-disturbance categories (Kruskal-Wallis, $p=0.034$ ). Species richness (total number of species) was nearly significant relative to site level-of-disturbance categories (Kruskal-Wallis, $\mathrm{p}=0.05$ ), with previously diked and dredged material placement sites having a higher species richness than historically present, locally disturbed, and landscape disturbance only sites. The average proportion of native plant species cover was also nearly significant relative to site level of disturbance (Kruskal-Wallis, $\mathrm{p}=0.083)$, with the highest proportions of native cover appearing at the historically present sites (.95), dredged material placement sites (.64), and landscape disturbance only sites (.61). Other metrics were not significantly different between site disturbance histories, including the number of observations with native species, number of observations of identical species, 
Table 3.10. Community characteristics. Major species identified have an average cover $>20 \%$.

\begin{tabular}{|c|c|c|c|c|c|c|c|c|c|c|c|c|}
\hline $\begin{array}{c}\text { Site } \\
\text { Disturbance } \\
\text { Code }\end{array}$ & $\begin{array}{l}\text { Site } \\
\text { Code }\end{array}$ & Type & $\begin{array}{c}\text { River } \\
\text { km }\end{array}$ & Zone & Year & $\begin{array}{c}\text { Avg. } \\
\text { Absolute } \\
\text { PHAR }(\%)\end{array}$ & $\begin{array}{c}\text { N of } \\
\text { Native } \\
\text { Species }\end{array}$ & $\begin{array}{c}\text { Total } \\
\text { Number of } \\
\text { Species }\end{array}$ & $\begin{array}{l}\text { Avg. number } \\
\text { species/quad }\end{array}$ & $\begin{array}{l}\text { Avg. } \\
\text { Native } \\
\text { Cover }\end{array}$ & $\begin{array}{c}\text { PHAR:NN } \\
\text { Cover }\end{array}$ & $\begin{array}{l}\text { Major } \\
\text { Species }\end{array}$ \\
\hline 0 & SRM-H & Marsh & 37 & EM1 & 2008 & 10.9 & 18 & 25 & 6.94 & 0.83 & 0.33 & CALY \\
\hline 0 & SRM-L & Marsh & 37 & EM1 & 2008 & 3.1 & 13 & 16 & 6.31 & 0.78 & 0.06 & SCTA \\
\hline 1 & WIM & Marsh & 53 & EM2 & 2008 & 4.0 & 22 & 27 & 11.45 & 0.77 & 0.04 & MEAR \\
\hline 1 & RIM & Marsh & 61 & EM2 & 2009 & 33.5 & 28 & 41 & 8.00 & 0.49 & 0.50 & PHAR \\
\hline 1 & MIM & Marsh & 129 & EM3 & 2007 & 15.0 & 23 & 33 & 5.10 & 0.66 & 0.54 & $\begin{array}{l}\text { PHAR } \\
\text { ELPA }\end{array}$ \\
\hline 1 & BIM & Marsh & 131 & EM3 & 2011 & 3.3 & 12 & 19 & 3.97 & 0.81 & 0.12 & SALA \\
\hline 1 & SBM & Marsh & 143 & EM4 & 2010 & 36.1 & 11 & 13 & 3.09 & 0.51 & 0.68 & $\begin{array}{l}\text { PHAR } \\
\text { SALA }\end{array}$ \\
\hline 1 & CLM & Marsh & 145 & EM4 & 2005 & 46.0 & 12 & 14 & 3.46 & 0.54 & 0.65 & $\begin{array}{l}\text { PHAR } \\
\text { ELPA }\end{array}$ \\
\hline 1 & CLM & Marsh & 145 & EM4 & 2006 & 17.2 & 8 & 11 & 2.87 & 0.62 & 0.60 & $\begin{array}{l}\text { PHAR } \\
\text { ELPA }\end{array}$ \\
\hline 1 & CLM & Marsh & 145 & EM4 & 2007 & 32.3 & 9 & 12 & 3.66 & 0.61 & 0.75 & $\begin{array}{l}\text { PHAR } \\
\text { ELPA }\end{array}$ \\
\hline 1 & CLM & Marsh & 145 & EM4 & 2008 & 24.3 & 10 & 12 & 3.13 & 0.60 & 0.54 & $\begin{array}{l}\text { PHAR } \\
\text { ELPA }\end{array}$ \\
\hline 1 & CLM & Marsh & 145 & EM4 & 2009 & 37.4 & 11 & 17 & 3.73 & 0.61 & 0.54 & $\begin{array}{l}\text { PHAR } \\
\text { ELPA }\end{array}$ \\
\hline 1 & CLM & Marsh & 145 & EM4 & 2010 & 51.4 & 13 & 18 & 3.35 & 0.42 & 0.67 & $\begin{array}{l}\text { PHAR } \\
\text { ELPA }\end{array}$ \\
\hline 1 & CLM & Marsh & 145 & EM4 & 2011 & 31.4 & 7 & 11 & 2.09 & 0.33 & 0.75 & PHAR \\
\hline 1 & GAM & Marsh & 200 & EM5 & 2008 & 1.4 & 11 & 13 & 2.45 & 0.94 & 0.05 & ELPA \\
\hline 1 & SIM & Marsh & 211 & EM5 & 2008 & 6.1 & 7 & 12 & 2.08 & 0.85 & 0.33 & ELPA \\
\hline
\end{tabular}


Table 3.10. (contd)

\begin{tabular}{|c|c|c|c|c|c|c|c|c|c|c|c|c|}
\hline $\begin{array}{c}\text { Site } \\
\text { Disturbance } \\
\text { Code }\end{array}$ & $\begin{array}{l}\text { Site } \\
\text { Code }\end{array}$ & Type & $\begin{array}{l}\text { River } \\
\text { km }\end{array}$ & Zone & Year & $\begin{array}{c}\text { Avg. } \\
\text { Absolute } \\
\text { PHAR }(\%)\end{array}$ & $\begin{array}{c}\mathrm{N} \text { of } \\
\text { Native } \\
\text { Species }\end{array}$ & $\begin{array}{c}\text { Total } \\
\text { Number of } \\
\text { Species }\end{array}$ & $\begin{array}{l}\text { Avg. number } \\
\text { species/quad }\end{array}$ & $\begin{array}{l}\text { Avg. } \\
\text { Native } \\
\text { Cover }\end{array}$ & $\begin{array}{c}\text { PHAR:NN } \\
\text { Cover }\end{array}$ & $\begin{array}{l}\text { Major } \\
\text { Species }\end{array}$ \\
\hline 1 & FLM & Marsh & 221 & EM5 & 2008 & 21.5 & 6 & 9 & 2.80 & 0.59 & 0.73 & $\begin{array}{l}\text { PHAR } \\
\text { SALA }\end{array}$ \\
\hline 1 & FLM & Marsh & 221 & EM5 & 2009 & 30.5 & 13 & 15 & 4.30 & 0.64 & 0.70 & PHAR \\
\hline 1 & FLM & Marsh & 221 & EM5 & 2011 & 27.3 & 13 & 15 & 3.60 & 0.54 & 0.79 & PHAR \\
\hline 1 & PIM & Marsh & 228 & EM5 & 2008 & 7.8 & 10 & 17 & 3.39 & 0.72 & 0.54 & ELPA \\
\hline 2 & BBM & Marsh & 6 & EM1 & 2011 & 0.0 & 15 & 16 & 3.90 & 0.99 & 0.00 & CALY \\
\hline 2 & $\mathrm{CHM}$ & Marsh & 12 & EM1 & 2009 & 0.0 & 13 & 15 & 5.08 & 1.00 & 0.00 & $\begin{array}{l}\text { CALY } \\
\text { CACA }\end{array}$ \\
\hline 2 & TBB & Marsh & 12 & EM1 & 2008 & 0.0 & 9 & 13 & 2.70 & 0.93 & 0.00 & $\begin{array}{l}\text { CALY } \\
\text { CACA }\end{array}$ \\
\hline 2 & $\mathrm{LCM}$ & Marsh & 20 & EM1 & 2009 & 21.3 & 14 & 20 & 3.07 & 0.75 & 0.34 & CALY \\
\hline 2 & CRM & Marsh & 80 & EM2 & 2009 & 48.3 & 15 & 24 & 6.09 & 0.34 & 0.55 & PHAR \\
\hline 2 & CS1 & Marsh & 149 & EM4 & 2005 & 40.2 & 6 & 8 & 2.39 & 0.56 & 0.59 & $\begin{array}{l}\text { PHAR } \\
\text { ELPA } \\
\text { SALA }\end{array}$ \\
\hline 2 & CS1 & Marsh & 149 & EM4 & 2006 & 24.3 & 7 & 10 & 2.16 & 0.60 & 0.49 & $\begin{array}{l}\text { PHAR } \\
\text { ELPA } \\
\text { SALA }\end{array}$ \\
\hline 2 & CS1 & Marsh & 149 & EM4 & 2007 & 22.0 & 6 & 15 & 2.40 & 0.56 & 0.48 & $\begin{array}{l}\text { PHAR } \\
\text { ELPA }\end{array}$ \\
\hline 2 & CS1 & Marsh & 149 & EM4 & 2008 & 19.6 & 9 & 16 & 2.64 & 0.58 & 0.44 & $\begin{array}{l}\text { PHAR } \\
\text { ELPA }\end{array}$ \\
\hline 2 & CS1 & Marsh & 149 & EM4 & 2009 & 36.4 & 12 & 21 & 3.11 & 0.61 & 0.44 & $\begin{array}{l}\text { PHAR } \\
\text { ELPA }\end{array}$ \\
\hline 2 & CS1 & Marsh & 149 & EM4 & 2010 & 37.9 & 16 & 24 & 3.15 & 0.57 & 0.55 & $\begin{array}{l}\text { PHAR } \\
\text { ELPA }\end{array}$ \\
\hline 2 & CS1 & Marsh & 149 & EM4 & 2011 & 28.2 & 10 & 13 & 2.10 & 0.51 & 0.59 & $\begin{array}{l}\text { PHAR } \\
\text { ELPA }\end{array}$ \\
\hline 2 & WRM & Marsh & 195 & EM5 & 2010 & 56.6 & 19 & 20 & 2.46 & 0.22 & 0.93 & PHAR \\
\hline 2 & OSR & Marsh & 196 & EM5 & 2006 & 10.3 & 13 & 16 & 2.68 & 0.53 & 0.70 & $\begin{array}{l}\text { PHAR } \\
\text { ELPA }\end{array}$ \\
\hline
\end{tabular}


Table 3.10. (contd)

\begin{tabular}{|c|c|c|c|c|c|c|c|c|c|c|c|c|}
\hline $\begin{array}{c}\text { Site } \\
\text { Disturbance } \\
\text { Code }\end{array}$ & $\begin{array}{l}\text { Site } \\
\text { Code }\end{array}$ & Type & $\begin{array}{l}\text { River } \\
\text { km }\end{array}$ & Zone & Year & $\begin{array}{c}\text { Avg. } \\
\text { Absolute } \\
\text { PHAR (\%) }\end{array}$ & $\begin{array}{c}\mathrm{N} \text { of } \\
\text { Native } \\
\text { Species }\end{array}$ & $\begin{array}{c}\text { Total } \\
\text { Number of } \\
\text { Species }\end{array}$ & $\begin{array}{l}\text { Avg. number } \\
\text { species/quad }\end{array}$ & $\begin{array}{l}\text { Avg. } \\
\text { Native } \\
\text { Cover }\end{array}$ & $\begin{array}{c}\text { PHAR:NN } \\
\text { Cover }\end{array}$ & $\begin{array}{c}\text { Major } \\
\text { Species }\end{array}$ \\
\hline 2 & OSM & Marsh & 198 & EM5 & 2007 & 1.6 & 22 & 32 & 3.17 & 0.58 & 0.11 & ELPA \\
\hline 3 & KIB & Marsh & 41 & EM2 & 2008 & 11.3 & 21 & 28 & 6.44 & 0.52 & 0.19 & -- \\
\hline 4 & MSC & Marsh & 39 & EM1 & 2009 & 0.0 & 7 & 12 & 6.40 & 0.56 & 0.00 & -- \\
\hline 4 & JIC & Marsh & 71 & EM2 & 2010 & 15.8 & 27 & 33 & 7.28 & 0.78 & 0.42 & CALY \\
\hline 4 & WHC & Marsh & 72 & EM2 & 2009 & 40.9 & 24 & 33 & 6.44 & 0.47 & 0.58 & PHAR \\
\hline 4 & WHC & Marsh & 72 & EM2 & 2010 & 49.3 & 25 & 36 & 7.40 & 0.39 & 0.62 & PHAR \\
\hline 4 & WHC & Marsh & 72 & EM2 & 2011 & 51.4 & 23 & 37 & 6.02 & 0.31 & 0.71 & PHAR \\
\hline 4 & WAC & Marsh & 77 & EM2 & 2010 & 21.8 & 22 & 30 & 6.35 & 0.33 & 0.31 & $\begin{array}{l}\text { PHAR } \\
\text { TYAN }\end{array}$ \\
\hline 4 & GUC & Marsh & 89 & EM2 & 2009 & 0.3 & 23 & 30 & 7.73 & 0.67 & 0.10 & $\begin{array}{l}\text { CAOB } \\
\text { MYSP }\end{array}$ \\
\hline 4 & LI1 & Marsh & 99 & EM2 & 2009 & 19.9 & 21 & 31 & 2.98 & 0.65 & 0.51 & $\begin{array}{l}\text { PHAR } \\
\text { ELCA }\end{array}$ \\
\hline 4 & LI2 & Marsh & 100 & EM3 & 2009 & 5.8 & 12 & 16 & 3.00 & 0.76 & 0.14 & SALA \\
\hline 4 & DIB & Marsh & 104 & EM3 & 2005 & 32.3 & 13 & 17 & 4.24 & 0.37 & 0.47 & PHAR \\
\hline 4 & CI1 & Marsh & 113 & EM3 & 2005 & 23.2 & 20 & 25 & 5.33 & 0.71 & 0.44 & $\begin{array}{l}\text { PHAR } \\
\text { ELPA }\end{array}$ \\
\hline 4 & CI1 & Marsh & 113 & EM3 & 2010 & 28.3 & 25 & 33 & 4.95 & 0.61 & 0.32 & PHAR \\
\hline 4 & CI2 & Marsh & 114 & EM3 & 2005 & 15.2 & 15 & 20 & 3.89 & 0.65 & 0.42 & $\begin{array}{l}\text { PHAR } \\
\text { ELPA }\end{array}$ \\
\hline 4 & CI2 & Marsh & 114 & EM3 & 2010 & 16.8 & 18 & 24 & 5.65 & 0.70 & 0.25 & ELPA \\
\hline 4 & SI1 & Marsh & 121 & EM3 & 2007 & 11.2 & 12 & 18 & 2.54 & 0.79 & 0.33 & $\begin{array}{l}\text { ELPA } \\
\text { SALA }\end{array}$ \\
\hline 4 & $\mathrm{SI} 2$ & Marsh & 123 & EM3 & 2007 & 42.0 & 9 & 17 & 2.23 & 0.35 & 0.71 & PHAR \\
\hline 4 & GIC & Marsh & 131 & EM3 & 2009 & 32.5 & 19 & 24 & 5.77 & 0.64 & 0.42 & $\begin{array}{l}\text { PHAR } \\
\text { ELPA }\end{array}$ \\
\hline 4 & GIC & Marsh & 131 & EM3 & 2011 & 14.9 & 8 & 11 & 2.31 & 0.48 & 0.67 & $\begin{array}{l}\text { PHAR } \\
\text { ELPA }\end{array}$ \\
\hline 4 & DIC & Marsh & 132 & EM3 & 2011 & 13.3 & 12 & 18 & 3.73 & 0.52 & 0.69 & $\begin{array}{l}\text { PHAR } \\
\text { ELPA }\end{array}$ \\
\hline 4 & DSI & Marsh & 136 & EM3 & 2007 & 16.6 & 21 & 28 & 4.54 & 0.78 & 0.55 & ELPA \\
\hline
\end{tabular}


Table 3.10. (contd)

\begin{tabular}{|c|c|c|c|c|c|c|c|c|c|c|c|c|}
\hline $\begin{array}{c}\text { Site } \\
\text { Disturbance } \\
\text { Code }\end{array}$ & $\begin{array}{l}\text { Site } \\
\text { Code }\end{array}$ & Type & $\begin{array}{c}\text { River } \\
\text { km }\end{array}$ & Zone & Year & $\begin{array}{c}\text { Avg. } \\
\text { Absolute } \\
\text { PHAR }(\%)\end{array}$ & $\begin{array}{c}\mathrm{N} \text { of } \\
\text { Native } \\
\text { Species }\end{array}$ & $\begin{array}{c}\text { Total } \\
\text { Number of } \\
\text { Species }\end{array}$ & $\begin{array}{l}\text { Avg. number } \\
\text { species/quad }\end{array}$ & $\begin{array}{l}\text { Avg. } \\
\text { Native } \\
\text { Cover }\end{array}$ & $\begin{array}{c}\text { PHAR:NN } \\
\text { Cover }\end{array}$ & $\begin{array}{l}\text { Major } \\
\text { Species }\end{array}$ \\
\hline 4 & $\mathrm{SSC}$ & Marsh & 154 & EM4 & 2005 & 37.7 & 6 & 9 & 2.49 & 0.42 & 0.53 & $\begin{array}{l}\text { PHAR } \\
\text { ELPA }\end{array}$ \\
\hline 4 & WRC & Marsh & 175 & EM4 & 2006 & 5.8 & 8 & 13 & 1.98 & 0.59 & 0.18 & $\begin{array}{l}\text { SALA } \\
\text { LUPA } \\
\text { LYSA }\end{array}$ \\
\hline 4 & $\mathrm{MIC}$ & Marsh & 190 & EM5 & 2006 & 3.0 & 11 & 16 & 2.64 & 0.79 & 0.35 & ELPA \\
\hline 4 & CIC & Marsh & 201 & EM5 & 2006 & 2.5 & 11 & 17 & 2.78 & 0.78 & 0.32 & ELPA \\
\hline 4 & RIC & Marsh & 201 & EM5 & 2007 & 8.9 & 12 & 17 & 3.95 & 0.79 & 0.55 & ELPA \\
\hline NA & $\mathrm{HC}$ & Marsh & 230 & EM5 & 2008 & 67.4 & 1 & 7 & 1.28 & 0.01 & 0.87 & PHAR \\
\hline 0 & GIM & $\begin{array}{l}\text { Marsh- } \\
\text { tributary }\end{array}$ & 23 & EM1 & 2009 & 0.0 & 18 & 23 & 6.50 & 0.85 & 0.00 & CALY \\
\hline 3 & FCB & $\begin{array}{l}\text { Marsh- } \\
\text { tributary }\end{array}$ & 19 & EM1 & 2008 & 23.6 & 12 & 17 & 4.15 & 0.72 & 0.33 & $\mathrm{CAOB}$ \\
\hline 3 & HIB & $\begin{array}{l}\text { Marsh- } \\
\text { tributary }\end{array}$ & 23 & EM1 & 2009 & 9.8 & 14 & 20 & 4.45 & 0.68 & 0.51 & SCTA \\
\hline NA & CSM & $\begin{array}{l}\text { Marsh- } \\
\text { tributary }\end{array}$ & 23 & EM1 & 2007 & 0.0 & 13 & 15 & 3.48 & 0.94 & 0.03 & $\begin{array}{c}\text { CAOB } \\
\text { ATFI }\end{array}$ \\
\hline 0 & $\mathrm{CCS}$ & Forested & 37 & EM1 & 2007 & 4.7 & 22 & 26 & 4.55 & 0.90 & 0.14 & POMU \\
\hline 0 & SRS & Forested & 37 & EM1 & 2008 & 2.1 & 20 & 23 & 2.36 & 0.86 & 0.15 & $\begin{array}{l}\text { CAHE } \\
\text { POMU }\end{array}$ \\
\hline 0 & KIS & Forested & 40 & EM2 & 2008 & 0.0 & 14 & 17 & 2.33 & 0.96 & 0.04 & IMSP \\
\hline 0 & CCR & Forested & 98 & EM2 & 2009 & 10.7 & 10 & 12 & 1.71 & 0.57 & 0.54 & PHAR \\
\hline 0 & GCR & Forested & 141 & EM4 & 2010 & 30.2 & 12 & 16 & 2.03 & 0.37 & 0.74 & PHAR \\
\hline 0 & SSS & $\begin{array}{l}\text { Forested- } \\
\text { tributary }\end{array}$ & 37 & EM1 & 2009 & 5.3 & 18 & 23 & 4.06 & 0.88 & 0.37 & LYAM \\
\hline 0 & WSH & Shrub/scrub & 53 & EM2 & 2009 & 8.5 & 41 & 51 & 5.29 & 0.77 & 0.20 & LYAM \\
\hline 0 & WSS & Shrub/scrub & 73 & EM2 & 2010 & 6.5 & 9 & 10 & 2.00 & 0.86 & 0.32 & $\begin{array}{c}\text { IMSP } \\
\text { LYAM }\end{array}$ \\
\hline
\end{tabular}




\section{Non-Native Species}

The proportion of observations with non-native plants was significantly lower $(0.26)$ in sites with landscape disturbance only than in all other disturbance categories except the historically present sites (0.05) (Kruskal-Wallis, $\mathrm{p}=0.015)$. The median cover of non-native species (\%) was not significantly different between level-of-disturbance categories $(\mathrm{p}=0.13)$, between wetland types (without sites in EM1, $p-0.10)$, or in a regression with $\log _{10}$ distance from the main channel $(p=0.65)$. The ratio of reed canarygrass cover to non-native species cover also did not significantly differ by disturbance category (Kruskal-Wallis, $\mathrm{p}=0.070$ ) or wetland type (without sites in EM1, $\mathrm{p}=0.13$ ) or in a regression with $\log _{10}$ distance from the main channel $(\mathrm{p}=0.55)$. Several other non-native species metrics were not significantly different by disturbance category: both relative and absolute percent cover of reed canarygrass $(p>0.07)$, and the number of observations with non-native species $(p=0.49)$. The relatively low average floodplain elevation of dredged material placement sites (Figure 3.3) may help explain why percent non-native cover is not necessarily higher at created sites.

\section{Discriminant Analysis of Marshes by Disturbance Category}

The best discriminant model of disturbance categories using all marshes and channel morphology and floodplain characteristics had a Wilks' lambda of 0.03 (Figure 3.10). Wilks' lambda provides a measure of the proportion of variance in the combination of modeled variables that is unaccounted for by the disturbance categories; smaller values indicate a better discrimination. The discriminant model correctly classified 20 of the 22 sites (91\%) that had no missing values in the modeled variables. Two discriminant functions explained $80 \%$ of the variability. Sites characterized as having had local or landscape disturbances were not well separated. Characteristics included in the model were average floodplain TOC $(\%)$, cross-sectional area $\left(\mathrm{m}^{2}\right)$, channel width $(\mathrm{m})$, bank elevation $(\mathrm{m})$, average yearly accretion/erosion rate $(\mathrm{cm})$, average channel fines $(\%)$, and average marsh fines $(\%)$. Recently reconnected sites were not included in this analysis because sediment grain size and TOC data were not available.

In comparison, the best discriminant model of EM zones using all marshes and channel morphology and floodplain characteristics had a Wilks' lambda of 0.009 and correctly classified all of the 22 sites (100\%) (Figure 3.11). Two discriminant functions explained $94 \%$ of the variability. Channel morphology and floodplain characteristics used in the model were channel width (m), width-to-depth ratio, channel depth $(\mathrm{m})$, average yearly accretion/erosion rate $(\mathrm{cm})$, thalweg elevation $(\mathrm{m})$, average channel fines $(\%)$, and average channel TOC $(\%)$.

The best discriminant model of disturbance categories using only marshes from zones EM2 through EM5 and community characteristics had a Wilks' lambda of 0.67 (Figure 3.12). The discriminant model correctly classified 34 of the 53 sites (64\%) that had no missing values in the modeled variables. One discriminant function explained $70 \%$ of the variability and two explained $100 \%$. The best discriminant model of EM zones using these marshes and community characteristics had a Wilks' lambda of 0.17 and correctly classified 42 of the 53 sites (79\%). One discriminant function explained $86 \%$ of the variability and two explained $99 \%$ of the variability. Characteristics included in these models were absolute cover of reed canarygrass, total number of species, average number of species/quadrat (patchiness), average native cover, and ratio of reed canarygrass to non-native cover to discriminate disturbance categories.

In summary, when using community characteristics we get better discrimination of sites by zone ( $79 \%$ correct classification) than we do by disturbance category ( $64 \%$ correct classification). 


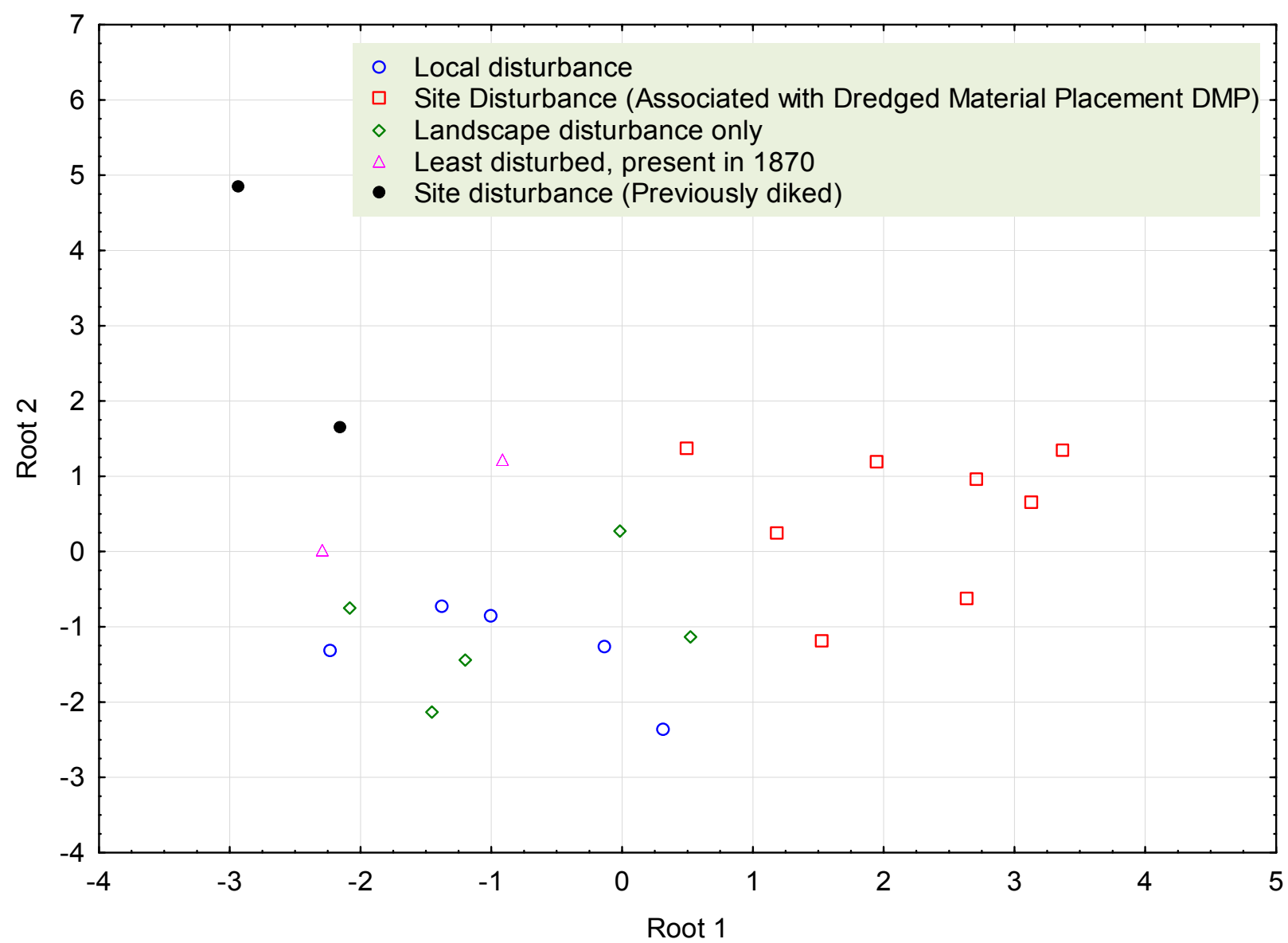

Figure 3.10. Root 1 and 2 of a discriminant function analysis of levels of disturbance.

\section{Similarity Analysis}

Similarity analysis of sites $(\mathrm{n}=22$, the number of sites with complete data) based on floodplain and channel characteristics included standardized data for average marsh TOC (\%), average channel TOC $(\%)$, bank elevation $(\mathrm{m})$, thalweg elevation $(\mathrm{m})$, channel depth $(\mathrm{m})$, cross-sectional area $\left(\mathrm{m}^{2}\right)$, channel width (m), width-to-depth ratio, average marsh fines (\%), average channel fines $(\%)$, proportion low marsh, and average site elevation (Figure 3.13). Hierarchical cluster analysis based on the Euclidean distance between sites resulted in three distinct groups indicated in the dendrogram by linking (using a common line color) sites that were at least 50\% similar, and three sites that are not similar to the others. Sites linked with red lines include disturbance categories $0,1,2$, and 3 , as well as one older 4 site (WHC) located off the main channel. Sites linked with blue lines include two category-4 and two category-1 sites, one of which is Sand Island (SIM), the only natural active dune area in LCRE according to Christy and Putera (1993). Sites linked with green lines are all disturbance category 4 dredged material placement sites. 

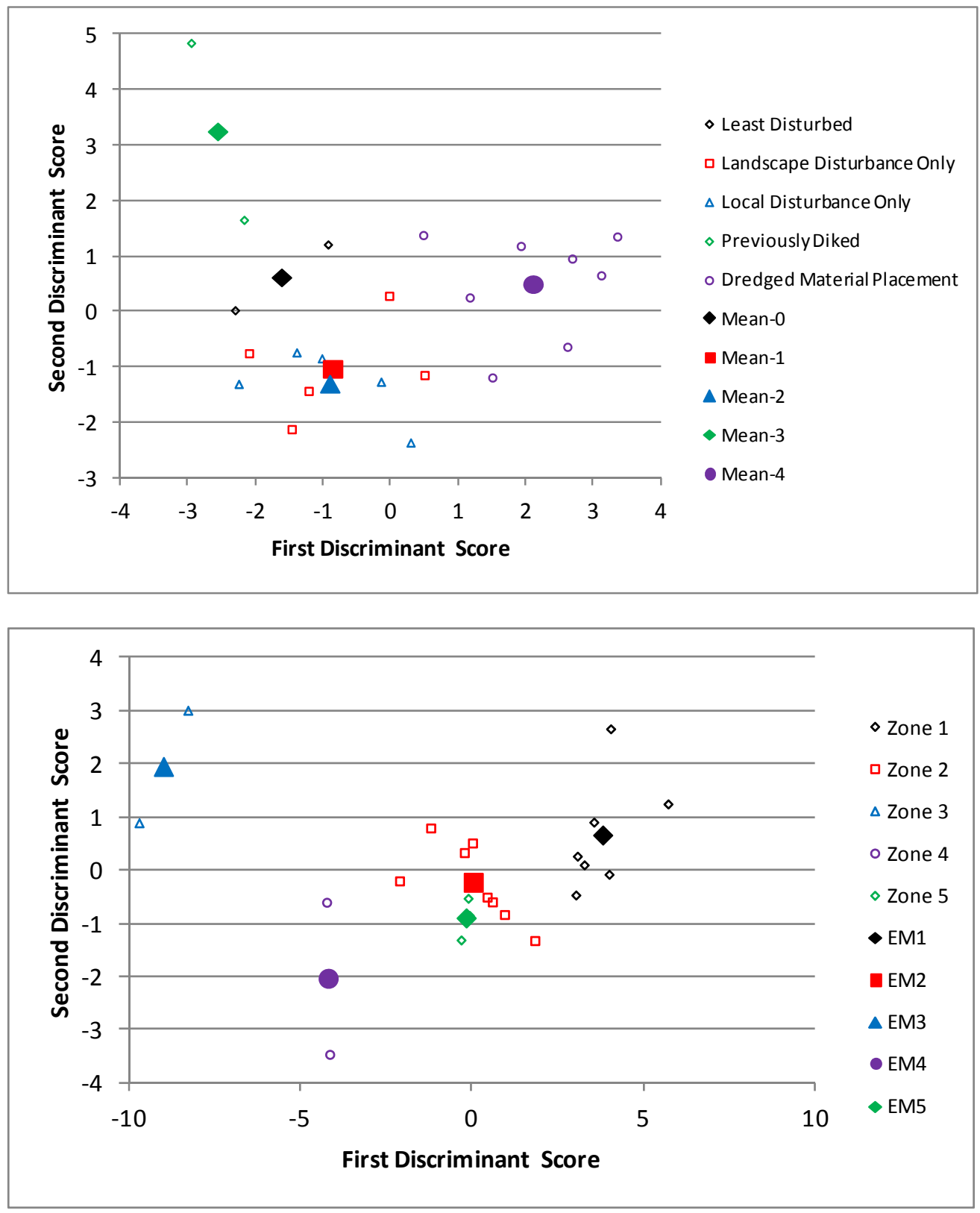

Figure 3.11. Comparison of the discrimination of disturbance levels (top panel) with the discrimination of emergent marsh zones (bottom panel) using channel and floodplain characteristics. 


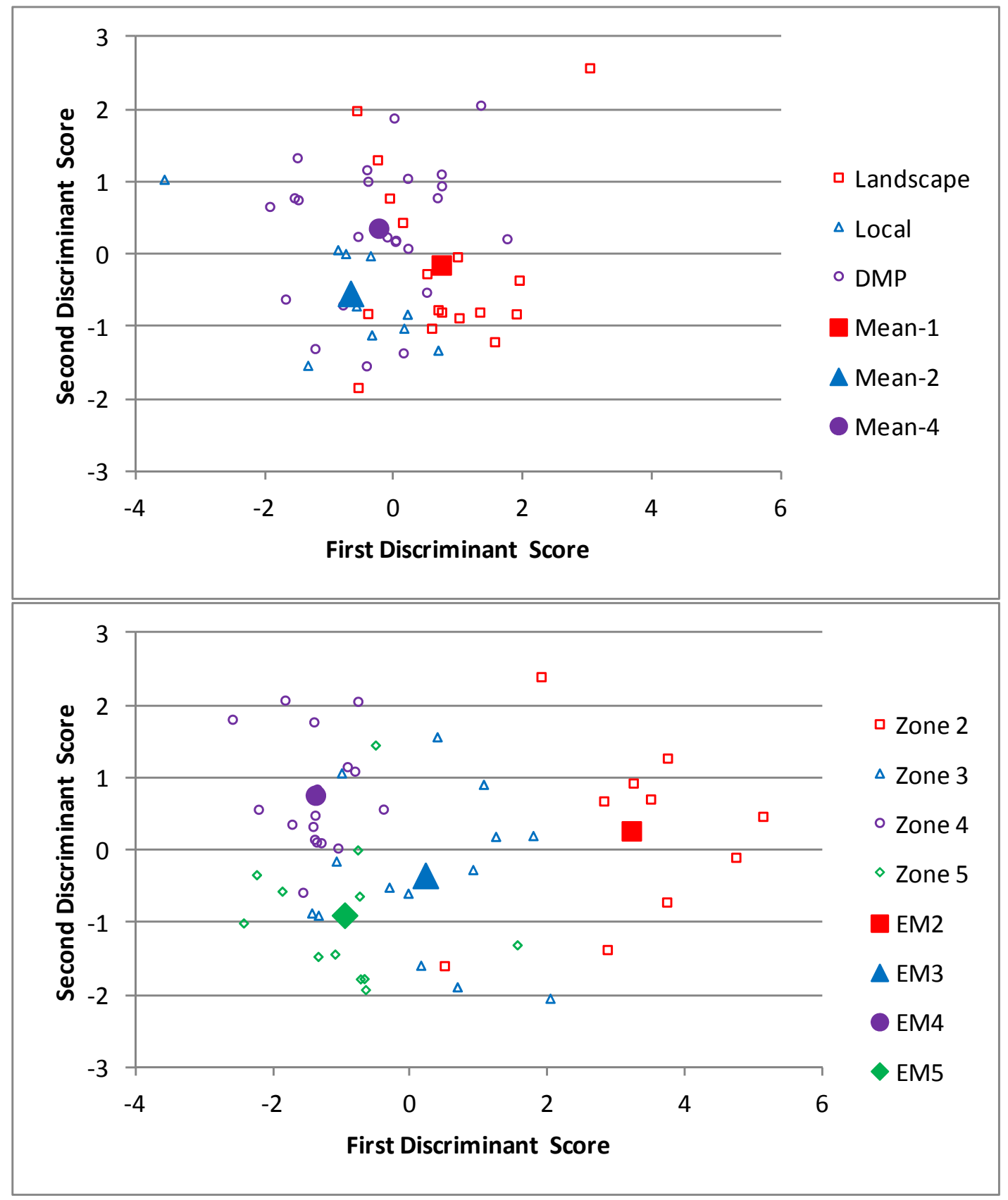

Figure 3.12. Comparison of the discrimination of disturbance levels (top panel) with the discrimination of emergent marsh zones using community characteristics (bottom panel). Note: DMP is dredged material placement 


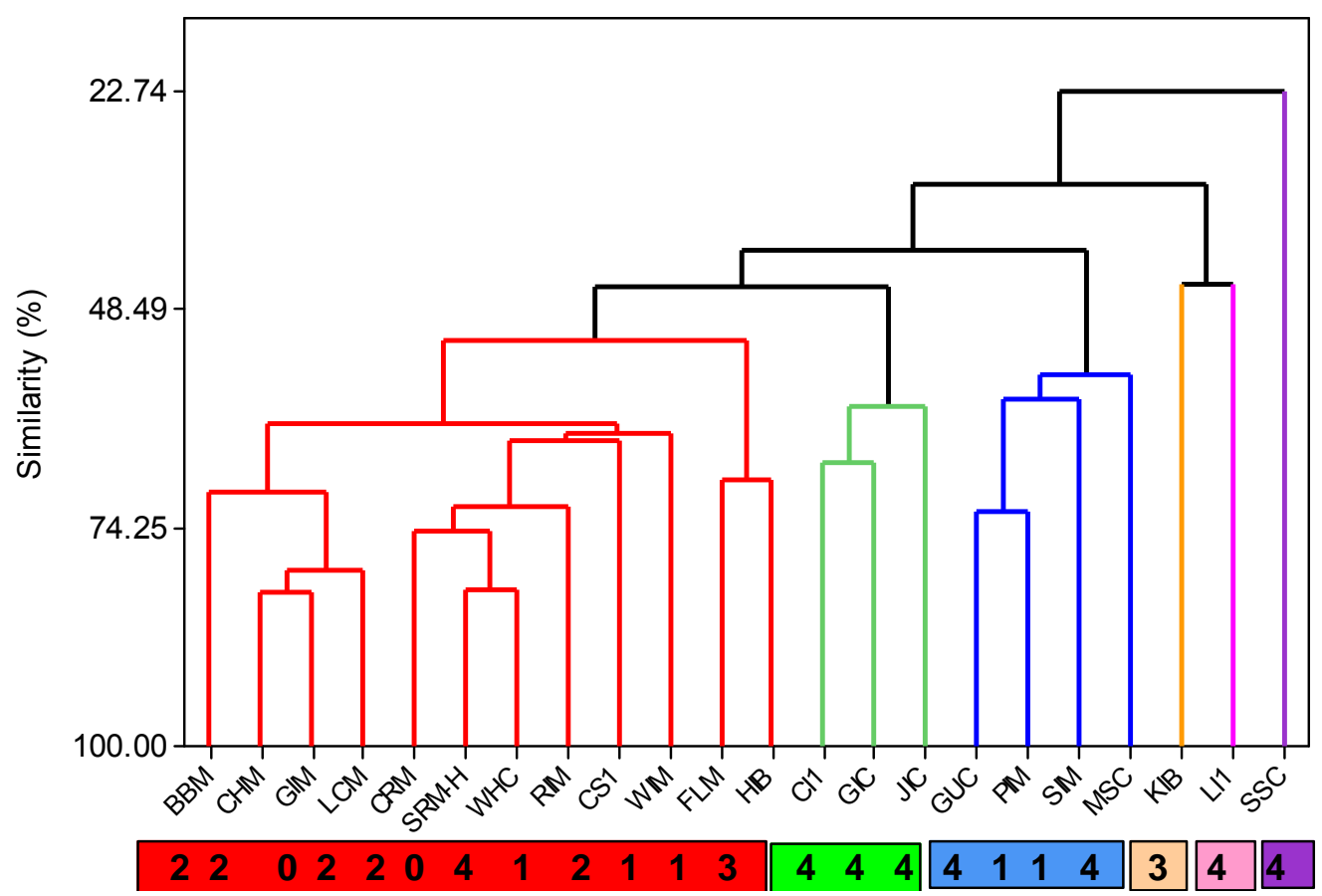

Figure 3.13. Dendrogram of average linkage, Euclidean distance between sites $(n=22)$ based on floodplain and channel characteristics.

Similarity analysis of sites ( $\mathrm{n}=53$, the number of marsh sites from zones EM2 to EM5 with complete data) based on plant community characteristics included standardized data for the absolute cover of reed canarygrass, the total number of species, the average number of species/quadrat (patchiness), average native cover, and the ratio of reed canarygrass to non-native cover (Figure 3.14). Hierarchical cluster analysis based on the Euclidean distance between sites resulted in six distinct groups indicated in the dendrogram by linking (using a common line color) sites that were at least $50 \%$ similar. Sites with multiple years of observation (indicated by the two digits following the site code) were clustered together in their given groups. The two sites linked with red lines include disturbance categories 1 and 4 , but are both within zone EM2 on the main channel of the river and have low percent cover of reed canarygrass. Sites linked with blue lines include disturbance categories 1, 2, and primarily 4 . Of these sites, Pierce Island (PIM), located just below Bonneville Dam, has a highly altered hydrograph; Martin Island and Goat Island (MIM and GIC) are affected by cattle grazing; and the former mouth of the Sandy River (OSM) is highly depositional in contrast to its historical flows. Sites linked with gold lines include disturbance categories 1 and primarily 4, and as a group are similar to the dredged material placement sites linked with blue lines. Of these sites, 5 of 8 are located in close proximity to each other in EM5; the remaining 3 (BIM, LI2, and SI1) have broad shallow sloughs. Sites linked with green lines include disturbance categories 1,2, and 4, and all sites in this category are in EM2. It should be noted that three of these observations represent multiple years at one site, Whites Island (WHC), which is one of the earliest dredged material placement sites we have observed in the LCRE (110 years since establishment). In contrast, the other category 4 site in this group is estimated to be 50 years old. Sites linked with pink lines primarily include disturbance categories 1 and 2, along with 5 category 4 sites. Sites in this group are located at some distance from the main channel in EM4 and EM5 with the exception of four sites: SI2, GIC, DIC, and DIB, which are all category 4 dredged material placement sites. Sites CLM, CS1, and FLM all include multiple years of observations that group closely together, as expected, and differences 
are likely explained by inter-annual variability in flow. The delta of the Washougal River (WRM) (the purple line) is the least similar site within the combined green and pink groupings and is the only active river delta site included in this analysis.

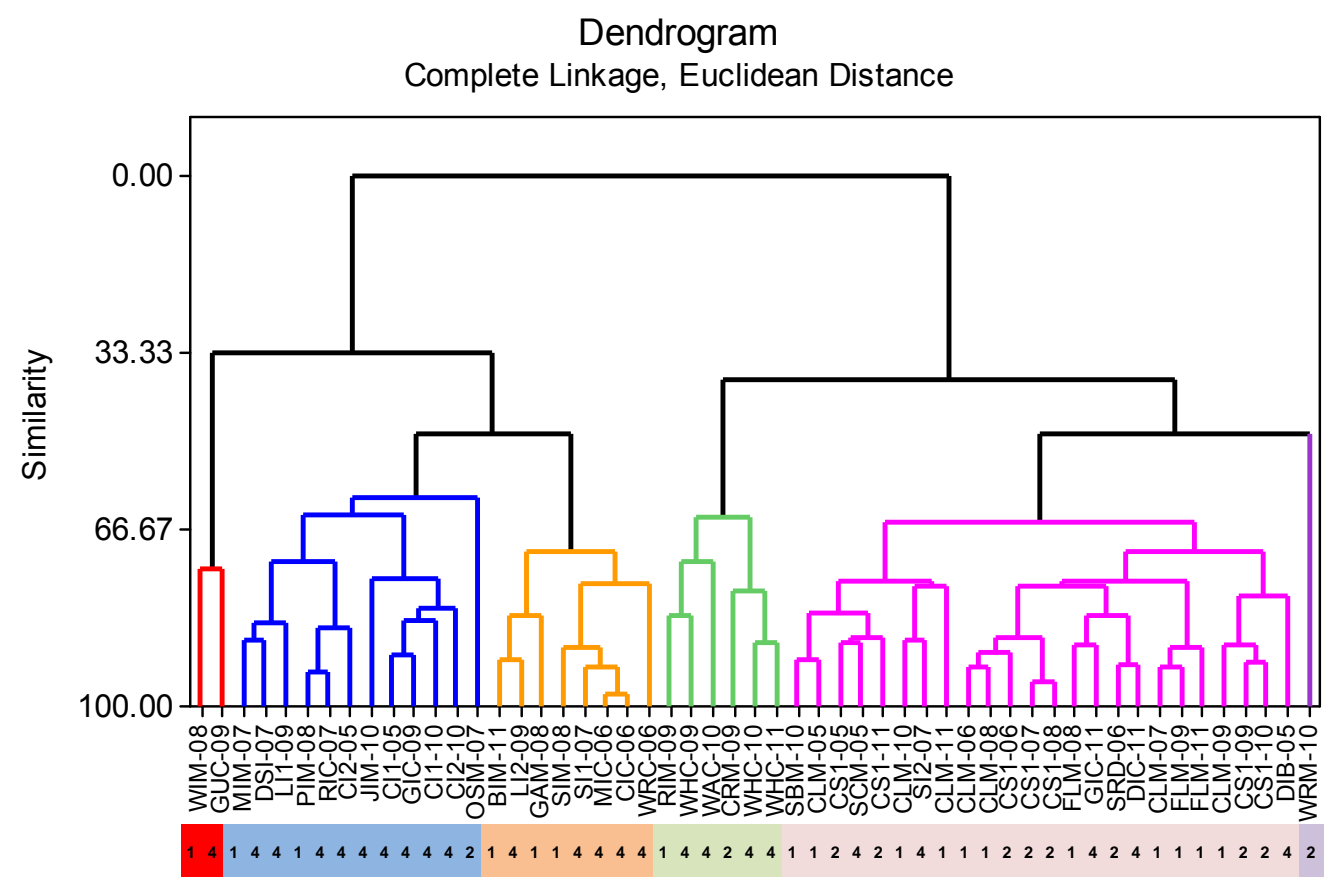

Figure 3.14. Dendrogram of complete linkage, Euclidean distance between sites $(n=53)$ based on community characteristics, with disturbance history category in the bar below.

Similarity analysis of sites ( $\mathrm{n}=55$ marsh sites from zones EM2-EM5 with complete data) based on average plant cover was conducted using Bray-Curtis similarity (Figure 3.15). Bray-Curtis similarity does not combine sites based on the absence of species; rather, it combines sites based on having similar cover for those species present. The analysis was based on the average site cover for 35 species which had at least 10 non-zero observations. Sites in the resulting nMDS plot were categorized (using symbols and color) to indicate the disturbance category. Sites placed closer together are more similar. The stress value of 0.17 (shown in the top right corner of the plot) indicates that a two-dimensional representation of the similarity matrix may not be as informative as a three dimensional representation. However, the plot still shows that dredged material placement sites are generally not similar to each other and have common species cover with specific sites based on other attributes (e.g., floodplain and channel characteristics, age, or location).

\section{Plant Species Presence and Cover}

For the purpose of this analysis, we sought to define a marsh by a single number associated with each of the plants that meet the stated criteria. First, we determined whether or not a plant species would be included in the analysis: the criteria were that a plant must be present in at least 10 quadrats (in the complete data set, not at each site) at any level of cover to be included. This requirement limits the number of plants in this analysis to those more often observed, even if the cover is very little. Thirty-five species from EM zones 2 through 5 were included in the analysis (sites in EM1 were not included because salinity introduces a confounding factor in the analysis). 

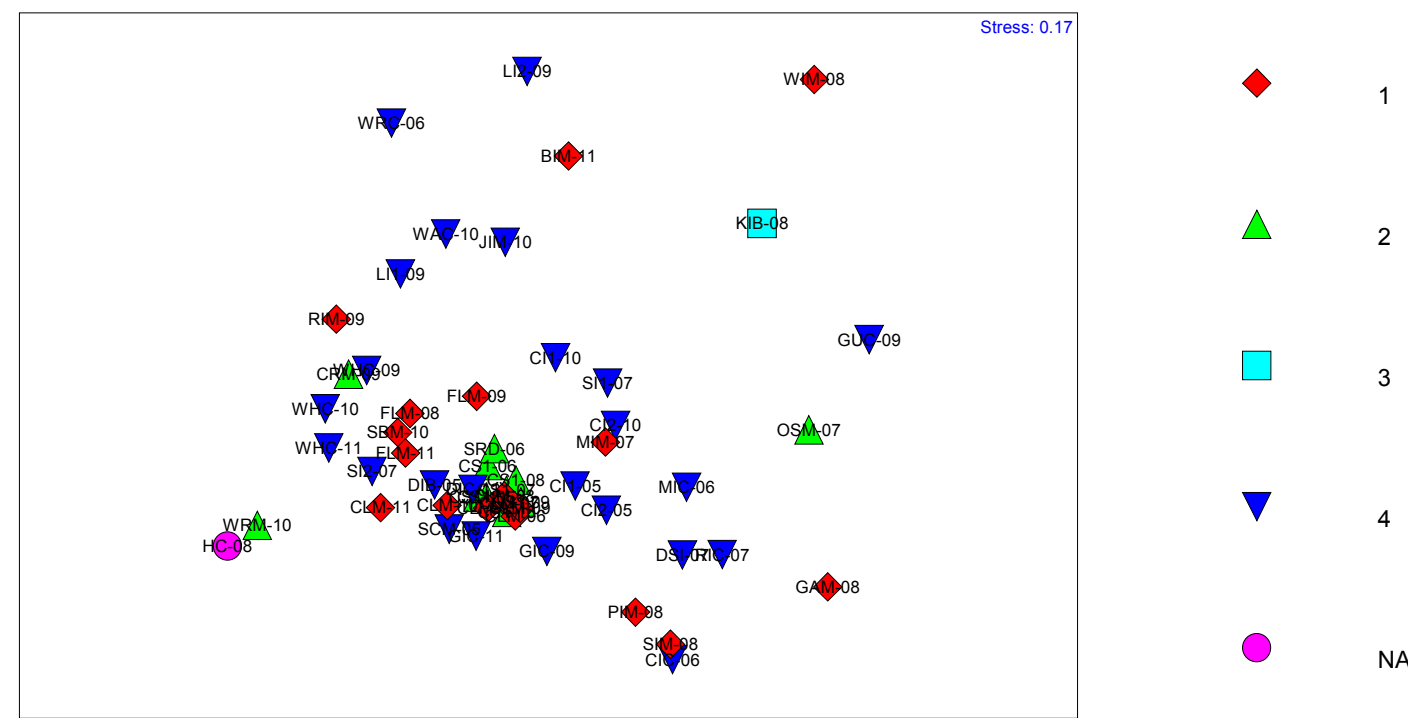

NA

Figure 3.15. Disturbance code categorized nMDS plot of the Bray-Curtis similarity of sites $(n=55)$ based on the average plant cover of 35 species.

Once the plant species for the analysis were identified in this way, we first counted all sites with any instance of these species. Average cover needed only to be $>0$ in a single quadrat, i.e. presence, to be counted. Once sites were counted, the results for each species were ranked, by disturbance categories, according to the number of counts (Table 3.11). A second analysis was conducted in which the average cover of each species was calculated for all sites within a disturbance category (Table 3.12).

Table 3.11. Herbaceous plant species present at a minimum of ten quadrats in the lower Columbia River and estuary marsh data set, compared according to presence in dredged material placement sites (category 4) and sites with local or landscape disturbances (catetories 1 and 2). Plants are in order of greater likelihood of occurence in the category (top of column). Highlighting indicates non-native plants.

\begin{tabular}{lll}
\hline \multicolumn{1}{c}{$\begin{array}{c}\text { More likely to occur in } \\
\text { disturbance categories 1 and 2 }\end{array}$} & More likely occur in disturbance category 4 & \multicolumn{1}{c}{$\begin{array}{c}\text { About the same likelihood of } \\
\text { occurrence in categories 1, 2, and 4 }\end{array}$} \\
\hline $\begin{array}{l}\text { Horsetail } \\
\text { Carex }\end{array}$ & Western lilaeopsis & Wapato \\
Common sneezeweed & Purple loosestrife & Common spikerush \\
Needle spikerush & American bulrush, threesquare bulrush & Reed canarygrass \\
Yellow iris & Pointed rush & Canada waterweed \\
Narrowleaf burreed & Small forget-me-not, Common forget-me-not & Softstem bulrush, tule \\
Spotted ladysthumb & Water mudwort & Coontail \\
Wild mint & Northern water plantain & Moneywort, Creeping Jenny \\
& American speedwell & Waterpepper, mild waterpepper, \\
Floating-leaved pondweed & Twoheaded water starwort & swamp smartweed \\
& & Water horsetail \\
& & False loosestrife \\
& & Rice cutgrass \\
& & Birdsfoot trefoil \\
& & Pacific silverweed \\
& & Slough sedge \\
& & Curly leaf pondweed \\
\hline
\end{tabular}


Table 3.12. Herbaceous plant species present at a minimum of 10 quadrats in the lower Columbia River and estuary marsh data set, compared according to cover in dredged material placement sites (category 4) and sites with local or landscape disturbances (catetories 1 and 2). Plants are in order of greater likelihood of occurence in the category (top of column). Highlighting indicates non-native plants.

\begin{tabular}{|c|c|c|}
\hline $\begin{array}{l}\text { More likely to have higher cover } \\
\text { in disturbance categories } 1 \text { and } 2\end{array}$ & $\begin{array}{c}\text { More likely to have higher cover in } \\
\text { disturbance category } 4\end{array}$ & $\begin{array}{c}\text { About the same likelihood of occurrence } \\
\text { in all categories }\end{array}$ \\
\hline \multirow{2}{*}{$\begin{array}{l}\text { Water mudwort } \\
\text { Carex }\end{array}$} & Purple loosestrife & Reed canarygrass \\
\hline & \multirow{2}{*}{$\begin{array}{l}\text { American bulrush, threesquare bulrush } \\
\text { Pointed rush }\end{array}$} & Common spikerush \\
\hline Spotted ladysthumb & & Wapato \\
\hline \multirow{3}{*}{$\begin{array}{l}\text { Coontail } \\
\text { Narrowleaf burreed } \\
\text { Wild mint }\end{array}$} & \multirow{4}{*}{$\begin{array}{l}\text { Western lilaeopsis } \\
\text { northern water plantain } \\
\text { American speedwell } \\
\text { Needle spikerush }\end{array}$} & Canada waterweed \\
\hline & & Slough sedge \\
\hline & & Curly leaf pondweed \\
\hline Yellow iris & & Pacific silverweed \\
\hline \multirow[t]{12}{*}{ Willow herb } & \multirow[t]{12}{*}{ Water horsetail } & False loosestrife \\
\hline & & Rice cutgrass \\
\hline & & Birdsfoot trefoil \\
\hline & & Moneywort, Creeping Jenny \\
\hline & & Twoheaded water starwort \\
\hline & & Yellow monkeyflower \\
\hline & & Horsetail \\
\hline & & Floating-leaved pondweed \\
\hline & & Common sneezeweed \\
\hline & & $\begin{array}{l}\text { Small forget-me-not, Common forget- } \\
\text { me-not }\end{array}$ \\
\hline & & Softstem bulrush, tule \\
\hline & & $\begin{array}{l}\text { Waterpepper, mild waterpepper, swamp } \\
\text { smartweed }\end{array}$ \\
\hline
\end{tabular}

In both analyses, the top three species (reed canarygrass, spike rush, and wapato) had the same rank in both dredged material placement and relatively undisturbed sites (Figure 3.16; the three dots at the lower left corner are ranked 1,2, and 3 respectively). In the analysis based on cover, many of the species are the same but the order of likelihood differs. Results of ranked analyses such as these require careful interpretation, and depend highly on the criteria for the analysis. Different criteria produce different ranked results and can result in a plant species being more likely to occur in a different category. For example, in a third analysis requiring that plant species be present in a minimum of 5 quadrats with a minimum of $>20 \%$ average cover in a quadrat, yellow iris is more likely to occur in disturbance category 4 , in contrast to the findings of the presence analysis reported in Table 3.11. All three analyses indicated that purple loosestrife is more likely to occur in disturbance category 4. (The criteria did result in the same set of species being included in all analyses, with one exception, Lyngby's sedge, which was present at between 5 and 10 quadrats at $>20 \%$ cover.) 


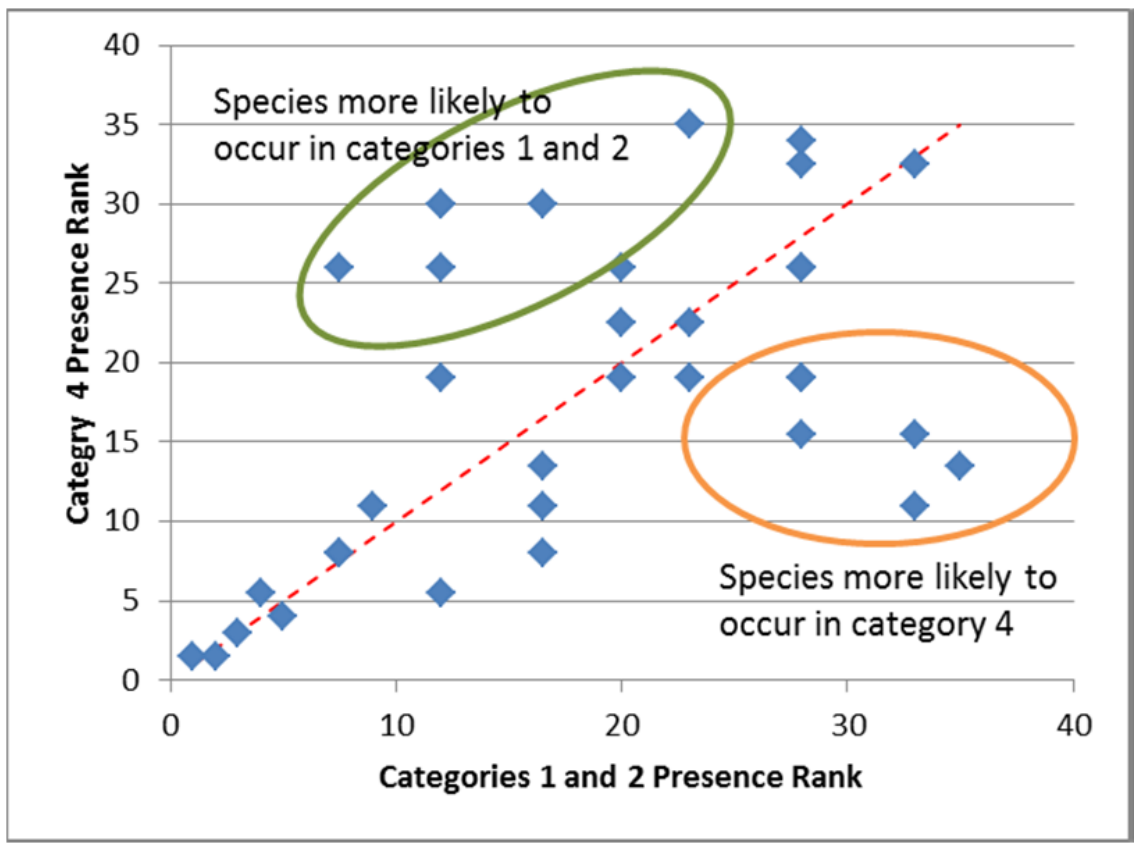

Figure 3.16. The likelihood of plant species presence in three disturbance categories. Each point represents a plant species (see Table 3.11). The red dashed line is the 1:1 line where ranked counts of species presence would be the same in both classes.

\subsubsection{Summary}

This section explores the variability of characteristics of sediments, channels, and plant communities across the LCRE relative to re-constructed histories of anthropogenic and natural disturbances at tidal wetlands. Five disturbance history categories were developed, and only 2 wetlands could not be classified because data were not available: Least disturbed, present in 1870; landscape-scale disturbance only; local-scale disturbance; site disturbance (previously diked); site disturbance (associated with dredged material placement); and recently reconnected. To explore the influence of connectivity through hydrologic and sedimentary processes, we also developed methods to measure the distance of each wetland from the main channel, for sites located in the main channel, bays, back-waters and tributaries.

Six wetland types are included in the assessment of data from 55 tidal wetlands and 3 newly restored sites in the LCRE between 2005 and 2011: main-stem emergent marsh (including low- and highelevation marsh), tributary marsh, shrub-dominated wetland, main-stem swamp (evergreen forested wetlands), tributary swamp, and riparian (deciduous forested wetland). This assessment is based on a synthesis of previously existing tidal wetland data on the physical environment and plants from five studies. The sample size of emergent marshes (43) provides greater confidence in the statistical results of this assessment than we have for other wetland types in the LCRE. This analysis relied on existing data, which collectively subsample the dynamic and spatially complex LCRE region, but comprise unequal sample sizes when categorized by influential factors such as disturbance history categories, EM zones, distance from the main channel, and wetland types. Therefore, the conclusions of statistical tests herein may be either strengthened or altered once further data are collected under programs such as Ecosystem Monitoring by the EP. 


\subsubsection{Descriptive Statistics}

Landscape Position. The distance from the main channel of the Columbia River ranged from $0 \mathrm{~km}$ (sites sharing a boundary with either the Columbia River or a side channel of the River, $\mathrm{n}=12$ ) to $12.02 \mathrm{~km}$ measured at Kandoll Farm, a recently reconnected tributary marsh. The median distance from the main channel was significantly different by disturbance category. Sample sites identified with dredged material placement were nearest the main channel while sites in the other disturbance categories were typically further away. Although the distance from the main channel was a poor predictor for all sediment and floodplain and channel characteristics $\left(\mathrm{R}^{2}<25 \%\right)$, significant slopes were detected for floodplain and channel TOC (\%), percent sand and fines, proportion low marsh, and average site elevation. Regression of community characteristics as a function of the distance from the main channel was not significant.

Sediment Characteristics. The first and third quartile of the data distribution provide a nonparametric range that would be considered typical of the sites sampled and are not influenced by the extreme observations. Table 3.13 summarizes the variables evaluated and whether the univariate analyses by disturbance category or the regression against the distance from the main channel was significant (indicated by a check mark). A summary of the results for each variable is also provided.

Table 3.13. Sediment characteristics and significance of the differences between disturbance categories and the regression against the distance from the main channel.

\begin{tabular}{lcc}
\hline \multicolumn{1}{c}{ Variable } & $\begin{array}{c}\text { Significant } \\
\text { Disturbance } \\
\text { Category }\end{array}$ & $\begin{array}{c}\text { Significant } \\
\text { Regression }\end{array}$ \\
\hline Sediment Accretion Rate (cm/yr) & - & - \\
Floodplain TOC (\%) & $\checkmark$ & $\checkmark$ \\
Channel TOC (\%) & - & $\checkmark$ \\
Floodplain Sand (\%) & - & $\checkmark$ \\
Channel Sand (\%) & - & $\checkmark$ \\
Floodplain Fines (\%) & - & $\checkmark$ \\
Channel Fines (\%) & - & $\checkmark$ \\
\hline$\checkmark=$ Significant & & \\
- = Not significant & & \\
\hline
\end{tabular}

The quartiles of the sediment accretion rate in marshes ranged from 0.12 to $1.55 \mathrm{~cm} / \mathrm{yr}$. The variability observed was not explained by the disturbance categories, wetland type, or the distance from the main channel. Some of the variability observed could be due to inter-annual variability, which was not included in this analysis because of the lack of data from multiple years at single sites. The quartiles of the sediment accretion rate in forested and shrub sites $(\mathrm{n}=8)$ ranged from 0.15 to $0.63 \mathrm{~cm} / \mathrm{yr}$.

The quartiles of the marsh TOC (\%) measured on the floodplain and within the channels ranged from $2.3 \%$ to $5.9 \%$ and $1.4 \%$ to $3.8 \%$, respectively. Sites associated with dredged material placement had a significantly lower TOC (\%) measured on the floodplain than sites that experienced only landscape or local disturbance, and generally lower TOC (\%) than all other disturbance categories. The variability observed in the TOC (\%) measured in the channel was not explained by the disturbance category. However, the TOC (\%) measured on the floodplain and within the channel increased with increasing 
distance from the main channel. The quartiles of the TOC $(\%)$ in forested and shrub sites $(\mathrm{n}=8)$ ranged from $4.0 \%$ to $5.9 \%$ on the floodplain and $1.8 \%$ to $3.4 \%$ within channels.

The quartiles of the marsh percentage sand measured on the floodplain and within the channels ranged from $17 \%$ to $37 \%$ and $19 \%$ to $54 \%$, respectively. The disturbance category did not explain the variability observed. Percentage sand decreased as a function of the distance from the main channel in both floodplain and channel observations. The quartiles of the forested and shrub sites $(\mathrm{n}=8)$ ranged from $19 \%$ to $39 \%$ sand and $24 \%$ to $39 \%$ sand measured in both floodplain and channel, respectively.

The quartiles of the marsh percentage fines measured on the floodplain and within the channels ranged from $62 \%$ to $83 \%$ and $39 \%$ to $81 \%$, respectively. The disturbance category did not explain the variability observed. Percentage fines increased as a function of the distance from the main channel in both floodplain and channel observations. The quartiles of the forested and shrub sites $(\mathrm{n}=8)$ ranged from $48 \%$ to $81 \%$ fines and $47 \%$ to $75 \%$ finds measured in both floodplain and channel, respectively.

Channel and Floodplain Morphology. The first and third quartile of the data distribution provide a nonparametric range that would be considered typical of the sites sampled and are not influenced by the extreme observations. Table 3.14 summarizes the variables evaluated and whether the univariate analyses by disturbance category or the regression against the distance from the main channel was significant (indicated by a check mark). A summary of the results for each variable is also provided.

Table 3.14. Channel and floodplain morphology and significance of the differences between disturbance categories and the regression against the distance from the main channel.

\begin{tabular}{lcc}
\hline \multicolumn{1}{c}{ Variable } & $\begin{array}{c}\text { Significant Disturbance } \\
\text { Category }\end{array}$ & $\begin{array}{c}\text { Significant } \\
\text { Regression }\end{array}$ \\
\hline Bank Elevation (m, CRD) & - & - \\
Thalweg Elevation (m, CRD) & $\checkmark$ & - \\
Channel Depth (m) & $\checkmark$ & - \\
Cross-Section Area (m $\left.{ }^{2}\right)$ & - & - \\
Channel Width (m) & - & - \\
Width:Depth Ratio & $\checkmark$ & - \\
Proportion Low Marsh & $\checkmark$ & - \\
Average Site Elevation (m, CRD) & $\checkmark$ & - \\
\hline$\checkmark=$ Significant & & \\
$-=$ Not significant & & \\
\hline
\end{tabular}

The quartiles of the bank elevation for main-stem marshes ranged from 1.03 to $1.88 \mathrm{~m}, \mathrm{CRD}$. The observed variability between marshes was not explained by the disturbance category or the distance to the main channel. The quartiles of the forested and shrub sites $(\mathrm{n}=8)$ ranged from 2.18 to $2.51 \mathrm{~m}, \mathrm{CRD}$.

The quartiles of the thalweg elevation for main-stem marshes ranged from 0.15 to $0.69 \mathrm{~m}, \mathrm{CRD}$. Significantly higher thalweg elevation were seen at sites that have been affected by local disturbances and dredged material placement, which could have implications for fish access to the wetland channels, particularly at low water levels. The observed variability between marshes was not explained by the distance to the main channel. The quartiles of the forested and shrub sites $(n=8)$ ranged from -1.07 to $0.13 \mathrm{~m}, \mathrm{CRD}$. 
The quartiles of the channel depth for main-stem and tributary marshes ranged from 0.44 to $1.46 \mathrm{~m}$. The median depth of dredged material placement sites was significantly shallower than historically breached and newly restored sites. The observed variability between marshes was not explained by the distance to the main channel. The quartiles of the forested and shrub sites $(n=8)$ ranged from 2.10 to $3.42 \mathrm{~m}$.

The quartiles of the cross-section area for main-stem and tributary marshes ranged from 4.6 to $36.6 \mathrm{~m}^{2}$. The median cross section area of previously diked and recently connected sites was significantly greater than all other disturbance categories. The observed variability between marshes was not explained by the distance to the main channel. The quartiles of the forested and shrub sites $(n=8)$ ranged from 28.3 to $70.6 \mathrm{~m}^{2}$.

The quartiles of the channel width for main-stem and tributary marshes ranged from 13.4 to $43.0 \mathrm{~m}$. The observed variability between marshes was not explained by the disturbance category or the distance to the main channel. The quartiles of the forested and shrub sites $(\mathrm{n}=8)$ ranged from 17.0 to $29.9 \mathrm{~m}$.

The quartiles of the width-to-depth ratio for main-stem and tributary marshes ranged from 12.9 to 42.8. The median width-to-depth ratio of channels at sites with dredged material placement was significantly greater than sites that were previously diked and generally greater than all other categories. The observed variability between marshes was not explained by the distance to the main channel. The quartiles of the forested and shrub sites $(n=8)$ ranged from 6.3 to 8.9.

The quartiles of the proportion low marsh (proportion of observed elevations less than $1.5 \mathrm{~m}, \mathrm{CRD}$ for main-stem marshes ranged from 0.17 to 0.65 . The median proportion low marsh was significantly greater at sites with dredged material placement than sites categorized as having only a local disturbance. The proportion low marsh decreased significantly with the distance to the main channel.

The quartiles of the average site elevation for main-stem marshes ranged from 1.33 to $1.98 \mathrm{~m}, \mathrm{CRD}$. The median site elevation was significantly lower at sites with dredged material placement than sites categorized as having only a local disturbance. The average site elevation increased significantly with the distance from the main channel. The quartiles of the forested and shrub sites $(\mathrm{n}=8)$ ranged from 2.58 to $2.94 \mathrm{~m}, \mathrm{CRD}$.

Plant Community Characteristics. Plant community characteristics were the primary focus of Section 2, however, several metrics were also included in this section to expand the analysis of disturbance categories. The first and third quartile of the data distribution provide a nonparametric range that would be considered typical of the sites sampled and are not influenced by the extreme observations. Table 3.15 summarizes the variables evaluated and whether the univariate analyses by disturbance category was significant (indicated by a check mark). The zones EM2 through EM5 are examined separately from the tidally dominated EM1, for reference, based on the results of the discriminant analysis above. 
Table 3.15. Plant community characteristics and significance of the differences between disturbance categories for main-stem marshes in the LCRE and only within zones EM2 through EM5.

\begin{tabular}{lcc}
\hline \multicolumn{1}{c}{ Variable } & Quartile Range & $\begin{array}{c}\text { Significant Disturbance } \\
\text { Category }\end{array}$ \\
\hline & EM1 through EM5 & - \\
Absolute Cover of Reed Canarygrass (PHAR \%) & $11 \%$ to $36 \%$ & - \\
Total Number of Species & 13 to 26 & - \\
Number of Species/Quadrat (Patchiness) & 3 to 5 & $\checkmark$ Category $2<$ All Others \\
Native Species Cover & $50 \%$ to $71 \%$ & - \\
Ratio of PHAR to Non-native Plant Cover & $34 \%$ to $66 \%$ & - \\
\multicolumn{1}{c}{ EM2 through EM5 } & - \\
Absolute Cover of Reed Canarygrass (PHAR \%) & $6 \%$ to $33 \%$ & - \\
Total Number of Species & 16 to 28 & - \\
Number of Species/Quadrat (Patchiness) & 3 to 5 & - \\
Native Species Cover & $50 \%$ to $77 \%$ & - \\
Ratio of PHAR to Non-native Plant Cover & 1.4 to 3.8 & \\
$\checkmark=$ Significant & & - \\
$-=$ Not significant & & - \\
\hline
\end{tabular}

\subsection{Planning Applications}

To prioritize where in the LCRE landscape restoration or creation projects are placed, and determine which specific restoration actions are designed at these locations, restoration ecologists must ask questions such as the following:

1. Does the distance from the main channel make a difference to the outcome of the restoration, because of variations in habitat-forming processes such as hydrology and sediment deposition, or other factors related to connectivity?

2. Does the type of action, e.g. dredged material placement or hydrologic reconnection, make a difference to the outcome of the restoration, because of variations in habitat-forming processes or factors such as soil characteristics?

3. Does the location of the action in a specific emergent marsh zone between the river mouth and Bonneville Dam make a difference to the outcome of the restoration, because of variations in habitatforming processes or factors such as salinity?

In this section, we reported significant differences between the disturbance categories for the distance of marsh and marsh-tributary sites from the main channel of the Columbia River (Kruskal-Wallis, $\mathrm{p}=$ 0.002); the average site elevation (Kruskal-Wallis, $\mathrm{p}=0.002$ ); and the proportion of low marsh to high marsh (Kruskal-Wallis, $\mathrm{p}=0.003$ ). In particular, the elevation of the dredged material placement sites is lower than other sites.

Analysis of plant species and plant community metrics produced varied results. Average plant cover, analyzed with similarity index methods, does not characterize differences between disturbance categories for marshes within zones EM2 through EM5 very well (Table 3.15, Figure 3.15). However, other plant community characteristics taken together-standardized data for the absolute cover of reed canarygrass, 
the total number of species, the average number of species/quadrat (patchiness), average native cover, and the ratio of reed canarygrass to non-native cover-do a somewhat better job of distinguishing between disturbance categories and EM zones (Figure 3.12, Figure 3.14). The results of ranked counts of species presence at sites also suggest that the likelihood of individual plant species occurring can distinguish some disturbance categories (Table 3.11, Figure 3.16).

Table 3.16. Summary of sites with an average site elevation below $1.5 \mathrm{~m}$, CRD relative to the average cover of reed canarygrass. Shaded rows indicate broad, low-elevation sloughs.

\begin{tabular}{ccccc}
\hline $\begin{array}{c}\text { Disturbance } \\
\text { Code }\end{array}$ & $\begin{array}{c}\text { Site } \\
\text { Code }\end{array}$ & $\begin{array}{c}\text { Average Site } \\
\text { Elevation }\end{array}$ & $\begin{array}{c}\text { Average \% Cover Reed } \\
\text { Canarygrass }\end{array}$ & $\begin{array}{c}\text { Average Non-native } \\
\text { Cover (\%) }\end{array}$ \\
\hline 1 & BIM & 1.18 & 3.3 & 19 \\
1 & SBM & 1.33 & 36.1 & 49 \\
1 & SIM & 1.13 & 6.1 & 15 \\
4 & JIC & 1.33 & 15.8 & 22 \\
4 & LI2 & 1.47 & 5.8 & 24 \\
4 & CI1 & 1.40 & $25.8^{(\mathrm{a})}$ & 37 \\
4 & CI2 & 0.98 & $16.0^{(\mathrm{a})}$ & 30 \\
4 & SI1 & 1.13 & 11.2 & 21 \\
4 & SI2 & 1.27 & 42.0 & 65 \\
\hline
\end{tabular}

(a) averaged between years

Inclusion of channel and floodplain characteristics greatly improves the ability to discriminate between disturbance histories and EM zones (Figure 3.12, Figure 3.13). Channel and floodplain characteristics included standardized data for average marsh/swamp TOC (\%), average channel TOC (\%), bank elevation $(\mathrm{m})$, thalweg elevation $(\mathrm{m})$, channel depth $(\mathrm{m})$, cross-sectional area $\left(\mathrm{m}^{2}\right)$, channel width $(\mathrm{m})$, width-to-depth ratio, average marsh/swamp fines (\%), average channel fines $(\%)$, proportion low marsh, and average site elevation.

Finally, adding information about landscape position, both distance from the main channel (lateral distance) and distance landward from the mouth toward Bonneville Dam (longitudinal distance) improves the ability to discriminate between the effects of disturbance. In this analysis, longitudinal distance was defined by the by emergent marsh zones 1 through 5 (Borde et al. 2012a).

However, these factors alone are not sufficient to explain differences in the establishment of plant communities in the LCRE. As an example, we analyzed two sites at the dredged material placement site Lord Island (LI1 and LI2) in EM3. These have effectively the same disturbance history and are located in the same EM zone. LI2 is 1,066 $\mathrm{m}$ from the main-stem river, located closer to the interior of the island, while LI1 is at the exterior of the island $0 \mathrm{~km}$ from the main stem. The most notable differences between the sites are in their morphology and plant communities: LI1 is a steep, high-elevation site with $20 \%$ cover of reed canarygrass, while LI 2 is a broad, low-elevation site with $6 \%$ cover of reed canarygrass. Most of the lowest elevation marsh sites in the EM zones 2-5 have had landscape-scale disturbance (category 1) or are dredged material placement sites (category 4), and most of these sites have a lower cover of reed canarygrass than the overall averages for disturbance category 1 (23.7\%) and disturbance category 4 (21.2\%) (Table 3.16). Based on these observations, we believe that morphology, elevation, 
landforms and process domains need to be considered to a greater extent than we have been able to in research to date. New information is becoming available that has the potential to enable such analyses to be conducted (http://water.usgs.gov/lookup/getspatial?CREEC_Geomorphic Catena).

Taking this information together with the findings of Section 2 concerning the influential role of land elevation, we hypothesize that elevation and other aspects of the physical morphology of the site may be most useful to planning and predicting restoration trajectories, both for the establishment of plant communities and for juvenile salmon habitat opportunity and capacity. In future planning, specifically for either dredged material sites or excavation, an experiment that could be effective is to create lowelevation marsh $(<1.5 \mathrm{~m})$ to enable more native species to establish as the site accretes, while inundation is still too great for reed canarygrass to establish. We suspect that when such a site reaches the elevation where more non-natives can dominate there may be less likelihood that they will dominate because of inter-species competition.

In summary, looking at these results from a restoration planning perspective, we can make the following conclusions. Based on the data sets we analyzed, sites where there were creation actions (i.e. ecosystem disturbances such as dredged material placement from 50 to 110 years ago) do not have plant communities that are easy to distinguish from the plant communities within marshes characterized by local or landscape disturbance, based on the average plant cover of 35 species. We believe this may be because all of the sites, regardless of disturbance category, have marshes with channel and floodplain characteristics that, under existing hydrologic conditions, promote reduced diversity and the invasion of non-native species (typically reed canarygrass); additionally, sites within different disturbance categories may be the same age. The average cover of only three plant species makes up a cumulative $70 \%$ of the marsh plant cover in EM2 through EM5: reed canarygrass, common spikerush, and wapato. We can say that if the marsh average elevation is greater than $1.5 \mathrm{~m}, \mathrm{CRD}$ then it is more likely to have reed canarygrass as the dominant species. Low marshes with broad flat morphologies are not likely to be dominated by reed canarygrass.

Sampling of a larger number of hydrologic reconnection restoration sites and improved site history information (including site age) may provide better discrimination in the future. Predictions of restoration outcomes in the near-term and long-term need to account for channel and floodplain characteristics and landscape position, which in our analysis did discriminate sites based on disturbance categories. Finally, future restoration planning may be able to alter floodplain characteristics to reduce the likelihood of producing marshes dominated by reed canarygrass. 


\subsection{Summary and Recommendations}

This report comprises two technical memoranda previously delivered to the U.S. Army Corps of Engineers, Portland District. The materials in this section were drawn from both documents to summarize this report.

\subsection{Summary - Planning Tools}

\subsubsection{Summary Data}

To the best of our knowledge, this is the first time that information about the distribution of individual plant species in terms of river extent and elevation has been elaborated this specifically for the LCRE region (Table 2.3-Table 2.8). These tables identify the most abundant herbaceous, shrub, and tree species in the region, by EM zone and wetland type, and can be used as a guide to the longitudinal and vertical distribution at which plant species are likely to survive in the region. The tables provide additional information important to planning, including whether the plant species is native or not, invasive/weedy or not, and its wetland status (e.g., facultative, obligate). We also present visual plots of the elevation minimum and maximum at which the most frequently present herbaceous plant species occur by river kilometer, for marshes (Figure 2.5a) and all other wetland types (Figure 2.5b). The most frequently occurring plants are identified (Table 2.9 and Table 2.10), as are the average site elevations of herbs, shrubs, and trees (Table 2.1 and Table 2.2). The information about plant species distribution has the potential to fundamentally inform future restoration planning in the LCRE region by increasing the ability to predict what wetland type is suitable for a site and what plant species could occur naturally or be successfully planted.

This information about plant species is augmented by tabular information about key physical and hydrologic metrics, to help planners to understand environmental conditions in the regions and wetland types they are concerned with. Such information includes: average transect slope (Table 2.11), growing season SEV (sum exceedance value) (Table 2.12), sediment accretion rate (Table 2.13 and Table 2.14), median 7-DADMAX water temperatures (Table 2.15), wetland channel morphology and inundation frequency (Table 2.16).

\subsubsection{Descriptive Statistics}

Non-native cover. The proportion of herbaceous plant species cover that is made up of non-natives is highest in deciduous forested wetlands followed by main-stem marshes. The proportion is substantially lower at tributary sites, evergreen forested wetlands, and shrub wetlands. (The larger sample size of marshes should be taken into account when interpreting these results, because it gives greater confidence than we have for other wetland types in the LCRE.) Reed canarygrass is the most prevalent non-native species in the LCRE. Reed canarygrass has a greater probability of occurring at elevations above $1.5 \mathrm{~m}$ in all zones except EM1, where it occurs at higher elevations with a lower probability $(<50 \%)$ of occurrence because of salinity.

Transect slope. The transect slope varies with the location in the floodplain and along the gradient of the river to some degree, although slope is variable in all locations. In general, there is a pattern of increasing slope up the tributaries and up the river. 
Floodplain inundation. Growing season SEV varies with elevation and flow. Therefore, the highest value of the maximum SEV occurs in low-elevation marshes near Bonneville Lock and Dam (maximum 4730), and the lowest value of the maximum SEV occurs in main-stem evergreen forested wetlands (0). The minimum value is 0 in evergreen forested wetlands, deciduous forested wetlands, and high-elevation shrub wetlands.

Sediment accretion/erosion rate. The minimum of the average sediment accretion rate occurred in mainstem evergreen forested wetlands $(0.24 \mathrm{~cm} / \mathrm{yr})$ and the maximum occurred in tributary emergent marshes $(1.21 \mathrm{~cm} / \mathrm{yr})$; however, there is no significant difference between wetland type.

Water temperature. - Water temperatures differ between tributary and main-stem sites, and in a given location vary between years. The lowest median 7-DADMAX water temperature recorded during our study periods was $8.4^{\circ} \mathrm{C}$ in a location between rkm 181 and 230 between March 15 and May 2, and the highest was $28.5^{\circ} \mathrm{C}$ between rkm 136 and 181 between August 22 and October 9. Water temperatures in the upper EM zones appear to be influenced by colder spring runoff, and in the lower EM zones by colder seawater in the late summer.

Channel morphology and inundation. For the most part, statistical tests did not distinguish metrics of channel morphology by EM zone or wetland type, because they are similar throughout the LCRE.

\subsubsection{Statistical Test Results}

The full suite of statistical tests performed in this assessment is listed in the Statistical Methods section. All significant results of statistical tests are reported here, while non-significant results are only reported if we regard them as contributing to existing knowledge of the LCRE system. These statistical results may be used to generate hypotheses that may be useful for future consideration, such as whether the emergent marsh zones are relevant for tidal wetland plant community restoration.

River position and elevation. The average emergent marsh site elevation in $m$ North American Vertical Datum of 1988 (NAVD88) significantly increases with river kilometer. The slope of a linear regression of average emergent marsh site elevation on river kilometer is significantly different from zero $(\mathrm{p}<0.05)$ between rkm 111 and Bonneville Lock and Dam, and nearly significantly different below rkm 111. Transect slopes significantly increase with river kilometer on main-stem marshes, but they are a poor predictor.

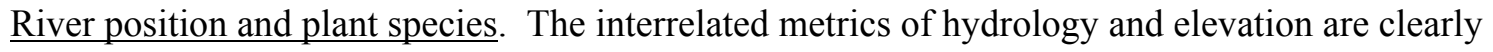
influential on plant community distribution in the LCRE region. For three of the most abundant plant species - reed canarygrass, common spikerush, and Lyngby sedge - the slope of the simple linear regression of the maximum observed elevation against the distance from the mouth of the Columbia River in kilometers was significant $(\mathrm{p}<0.05)$. For two plant species - reed canarygrass and Lyngby sedge-the regression of the minimum observed elevation against the distance from the mouth of the Columbia River in kilometers was significant. The average non-native cover increased significantly $(\mathrm{p}<0.001)$ until $\mathrm{rkm}$ 60 ; further landward it remained consistent. The number of sites with reed canarygrass cover $>20 \%$ is significantly fewer in EM1 and significantly greater in EM5. 
Elevation and plant species. The number of sites with reed canarygrass cover $>20 \%$ was significantly greater between elevation of 1.5 to 3 than below 1.5 and above $3 \mathrm{~m}$, CRD, however, sampling intensity was lower above $3 \mathrm{~m}, \mathrm{CRD}$. Transect slope was not significantly associated with metrics describing plant communities or species.

Main-stem river zonation and tributaries. Study sites categorized as marshes that had never been diked were discriminated with $100 \%$ correct classification into five hypothesized EM zones based on the abundance of major herbaceous plants and their associated SEVs. These five zones, the delineation of tributary versus main-stem regions, and general wetland cover type (marsh, swamp, shrub) allowed us to characterize and differentiate between major influences on the longitudinal and vertical distribution of wetland plants. (However, because of a lack of data for wetlands on tributary rivers of EM2 - EM5, we cannot extrapolate our findings on tributaries further up the Columbia River.) The major findings are that average sediment accretion rates did not significantly differ between EM zones, however, the ratio of channel width and depth did.

Wetland type. Swamps had significantly smaller SEVs than emergent marshes (Kruskal-Wallis: $n=43$; $\mathrm{p}=0.001$ ). The width-to-depth ratio of the primary wetland channel at its mouth was significantly different between wetland types. At our study sites, the average transect slope, sediment accretion rates, and proportion of non-native plant species cover were not significantly different between wetland types.

Environmental factors and river position. The SEV, a hydrologic regime indicator, increases significantly with increasing river kilometer and decreases significantly with average wetland elevation. Water temperature was analyzed during three periods over 4 years with the following results: March 15 to May 2 - only water temperatures in the year 2010 significantly increased with river kilometer; May 3 to June 20 - temperatures in both 2008 and 2009 significantly decreased with river kilometer, with no difference in slope; August 22 to October 9 - 2009 water temperatures significantly increased with river kilometer.

\subsection{Recommendations}

To the best of our knowledge, this is the first time that extensive environmental information about tidal wetlands of the LCRE has been summarized, analyzed and compared according to disturbance history categories of this kind. Therefore, our understanding of the implications of these analyses could be improved by the addition of other data and other analytical approaches. We consider the analyses relative to disturbance herein to be exploratory and preliminary at this time. Several lines of inquiry could be pursued toward a greater understanding of habitat function for juvenile salmon to inform restoration planning and design.

For instance, analyses of environmental data such as we have reported herein could be coupled with beach seine data and/or data on salmon prey identified in sources including stomach contents, benthic cores, and insect fallout traps to help to verify salmon habitat function. The results reported in this section also indicate that some additional multivariate analyses of the environmental data could be beneficial, e.g., although the dredged material placement site category did not explain water temperatures, a finer resolution category such as the width-to-depth ratio of channels could be usefully analyzed relative to temperatures and may have the potential to distinguish seasonality of salmon habitat function. 
Based on knowledge gathered over several years of data collection and continually increasing understanding of the limitations of some types of data, we would recommend that scientists consider the following factors when planning future data collection and analyses: 1) main-stem marshes are surveyed using the CRD, thus, their elevations cannot be directly compared to elevations surveyed in tributary marshes using NAVD88; 2) marshes subject to strong tidal influences may be constrained in their lower elevation limits because of desiccation during low tides; 3 ) the plant communities at sites low in the LCRE affected by higher salinity cannot be directly compared to tidal freshwater sites in the remainder of the study area; and 4) while many marshes are sampled for vegetation in a single year, those with multiple survey years may also be averaged to obtain community characteristics depending on the analytical question.

The focus of this research could benefit from more complete information about the disturbance history and age of the tidal wetlands. Through the analysis of aerial photos to ascertain the year each vegetated wetland first appears, in coordination with the Corps' pile-dike inventory (AECOM 2011), it may be possible to assign ages to reference wetlands and definitively associate wetlands with pile dikes, and thereby to increase the temporal granularity of the analysis and the specificity of disturbance history categories. Such new information could inform a reanalysis of existing biological and ecological data according to pile-dike-specific disturbance history and wetland age. Such an analysis would focus more on the development and change of wetland attributes at time scales from years to decades at created, previously diked, and relatively undisturbed sites, including sites affected by pile dikes, whereas the analyses herein use disturbance history to examine temporal effect.

It would also be possible to conduct further analyses of each specific category of disturbance history, e.g., the effects of pile dikes or dredged material placement on hydrologic and sedimentary processes and in turn, the development of ecosystem structures (e.g., vegetation) and functions (e.g., juvenile salmon habitat; organic matter export). In addition to aerial photo analysis, a necessary precursor to such analysis would be historical analysis, including for example records of management actions such as pile-dike construction records and dredged material placement records, to characterize the disturbance history of each wetland. Also, GIS analysis would be required to characterize the spatial position of disturbances relative to existing reference wetlands where data have been collected, and connectivity between the two. Such an analysis could describe ecological structures and processes of wetlands associated with pile dikes; determine whether wetlands associated with pile dikes have ecological structures and processes that are similar to other wetlands in the LCRE having different disturbance histories; determine whether the age of a wetland associated with a pile dike helps to explain its present ecological structures and processes; and determine whether the ecological structures and processes of pile-dike-associated tidal wetlands are explained in part by river position (i.e., river kilometer).

Finally, the results of both Section 2 and Section 3, reporting our synthesis, analysis, and comparison of existing data on ecosystem structures and processes at tidal wetlands in the LCRE point to similar controlling factors of hydrology, geology, morphology, and elevation at specific restoration sites. These factors may overwhelmingly guide the trajectory of development of sites, and therefore, these factors bear further investigation relative to the ecological data, to support restoration planning. 


\subsection{References}

AECOM. 2011. Structural and Hydraulic Analysis of Columbia River Pile Dikes: Final Report. Prepared for the U.S. Army Corps of Engineers, Portland District, Portland, Oregon, by AECOM, Seattle, Washington.

Araya YN, J Silvertown, DJ Gowing, KJ McConway, HP Linder, and G Midgley. 2011. "A fundamental, eco-hydrological basis for niche segregation in plant communities." New Phytologist 189:253-258. doi: 10.1111/j. 1469-8137.2010.03475.x.

Borde AB, SA Zimmerman, RM Kaufmann, HL Diefenderfer, NK Sather, RM Thom. 2011. Lower Columbia River and Estuary Restoration Reference Site Study: 2010 Final Report and Site Summaries. PNWD-4262, prepared for the Lower Columbia River Estuary Partnership by Pacific Northwest National Laboratory, Marine Sciences Laboratory, Sequim, Washington.

Borde AB, VI Cullinan, HL Diefenderfer, RM Thom, RM Kaufmann, J Sagar, and C Corbett. 2012a. Lower Columbia River and Estuary Ecosystem Restoration Program Reference Site Study: 2011

Restoration Analysis. PNNL-21433, prepared for the Lower Columbia River Estuary Partnership by Pacific Northwest National Laboratory, Richland, Washington.

Borde AB, RM Kaufmann, VI Cullinan, SA Zimmerman, and CL Wright. 2012b. Lower Columbia River and Estuary Habitat Monitoring 2011 Annual Report. PNNL-21128, prepared for the Lower Columbia River Estuary Partnership by Pacific Northwest National Laboratory, Richland, Washington.

Burke JL. 2010. Georeferenced Historical Topographic Survey Maps of the Columbia River Estuary. School of Aquatic and Fishery Sciences, University of Washington, Seattle, Washington.

Christy JA and JA Putera. 1993. Lower Columbia River natural area inventory: 1992. Oregon Natural Heritage Program, Portland, Oregon.

Clarke KR and RN Gorley. 2006. PRIMER v6: User Manual/Tutorial. PRIMER-E, Plymouth, Massachusetts.

Clarke KR and RM Warwick. 1994. "Change in marine communities: an approach to statistical analysis and interpretation." Natural Environment Research Council, London.

Cowardin, LM, V Carter, FC Golet and ET LaRoe. 1979. "Classification of wetlands and deepwater habitats of the United States." FWS/OBS 79/31, U.S. Fish and Wildlife Service U.S. Department of the Interior Fish and Wildlife Service, Office of Biological Services, Washington, D.C.

Diefenderfer HL, AB Borde, GC Roegner, EM Dawley, MT Russell, and AS Cameron. 2010. Appendix $C$ - Ecological trajectories and salmon habitat functions of historical dike breaches and created islands in the Columbia River floodplain, USA. Pages C.1-C.24 in Johnson GE and HL Diefenderfer (eds.)

"Evaluating Cumulative Ecosystem Response to Restoration Projects in the Lower Columbia River and Estuary, 2009." PNNL-19440, prepared by Pacific Northwest National Laboratory, Richland, Washington for the U.S. Army Corps of Engineers, Portland District, Portland, Oregon. 
Diefenderfer HL, AM Coleman, AB Borde, and IA Sinks. 2008. "Hydraulic geometry and microtopography of tidal freshwater forested wetlands and implications for restoration, Columbia River, U.S.A." Ecohydrology and Hydrobiology 8:339-361. Proceedings of the International Conference "Ecohydrological Processes and Sustainable Floodplain Management Opportunities and Concepts for Water Hazard Mitigation and Ecological and Socioeconomic Sustainability in the Face of Global Changes," 19-23 May 2008, Lodz, Poland. doi:10.2478/v10104-009-0027-7.

Gowing DJG, CS Lawson, EG Youngs, KR Barber, JS Rodwell, MV Prosser, HL Wallace, JO Mountford, and G Spoor. 2002. The water regime requirements and the response to hydrological change of grassland plant communities. Project BD1310 for the Department of Environment, Food, and Rural Affairs by Institute of Water and Environment, Bedford, UK.

Jay DA, K Leffler, H Diefenderfer, and A Borde. In review. "Tidal-fluvial and Estuarine Processes in the Lower Columbia River: I. Along-channel Water Level Variations, Pacific Ocean to Bonneville Dam." Estuaries and Coasts.

Haskell CA and KF Tiffan. 2011. Crims Island-Restoration and monitoring of juvenile salmon rearing habitat in the Columbia River Estuary, Oregon, 2004-10. U.S. Geological Survey Scientific Investigations Report 2011-5022, Reston, Virginia.

Johnson GE, HL Diefenderfer, RM Thom, GC Roegner, BD Ebberts, JR Skalski, AB Borde, EM Dawley, AM Coleman, DL Woodruff, SA Breithaupt, AS Cameron, CA Corbett, EE Donley, DA Jay, Y Ke, KE Leffler, CB McNeil, CA Studebaker, and JD Tagestad. 2012. Evaluation of Cumulative Ecosystem Response to Restoration Projects in the Lower Columbia River and Estuary. PNNL-20296, prepared for the U.S. Army Corps of Engineers, Portland District, Portland, Oregon, by Pacific Northwest National Laboratory, Richland, Washington.

Leopold LB and T Maddock Jr. 1953. "Hydraulic geometry of stream channels and some physiographic implications.” Geological Survey Professional Paper 252. U.S. Government Printing Office, Washington, D.C.

Natural Resource Conservation Service (NRCS). 2002. Wetland determination (WETS) table for Clark County, Washington. Available at http://www.wcc.nrcs.usda.gov/ftpref/support/climate/wetlands/wa/53011.txt

NMFS (National Marine Fisheries Service). 2008. Biological Opinion - Consultation on Remand for Operation of the Federal Columbia River Power System, 11 Bureau of Reclamation Projects in the Columbia Basin and ESA Section 10(a)(1)(A) Permit for Juvenile Fish Transportation Program. NMFS (National Oceanic and Atmospheric Administration Fisheries) - Northwest Region, Seattle, Washington.

PC Trask and Associates. 2009. Contract Deliverables Tasks 1-8. Prepared for Portland District Army Corps of Engineers, Contract \#W9127N, December 31, 2009.

Roegner GC, HL Diefenderfer, AB Borde, RM Thom, EM Dawley, AH Whiting, SA Zimmerman, and GE Johnson. 2009. Protocols for Monitoring Habitat Restoration Projects in The Lower Columbia River and Estuary. NMFS-NWFSC-97, National Oceanic and Atmospheric Administration Technical 
Memorandum. U.S. Department of Commerce, Seattle, Washington. Available at http://www.nwfsc.noaa.gov/publications/displayinclude.cfm?incfile=technicalmemorandum2009.inc

Sagar, JP, KE Marcoe, CA Simenstad, MF Ramirez, JL Burke, JE O'Connor, TD Counihan, IR Waite, A B Borde, SA Zimmerman, NK Sather, RM Thom, JL Morace, LL Johnson, PM Chittaro, KH Macneale, OP Olson, SY Sol, DJ Teel, GM Ylitalo, and LK Johnson. 2011a. Ecosystem Monitoring Project Annual Report for Year 6. Lower Columbia River Estuary Partnership, Portland, Oregon.

Sather N, D Teel, A Storch, G Johnson, E Van Dyke, E Dawley, D Kuligowski, T Jones, A Bryson, and K Sobocinski. 2011. "Juvenile Salmon and Fish Community Characteristics." In Ecology of Juvenile Salmon in Shallow Tidal Freshwater Habitats of the Lower Columbia River, 2007-2010, Johnson et al. 2011, pp. 2.1-2.35, PNNL 20083, Pacific Northwest National Laboratory, Richland, Washington.

Simon, S.D., M.E. Cardona, B.W. Wilm, J.A. Miner, and D.T. Shaw. 1997. The sum exceedance value as a measure of wetland vegetation hydrologic tolerance. In: Macdonald, K.B. and F. Weinmann (eds). 1997. Wetland and Riparian Restoration: Taking a Broader View. Proceedings of Society for Ecological Restoration, 1995 International Conference, September 14-16, University of Washington, USA. Publication EPA 910-R-97-007, USEPA, Region 10, Seattle, Washington.

Williams GD and JB Zedler. 1999. "Fish assemblage composition in constructed and natural tidal marshes of San Diego bay: relative influence of channel morphology and restoration history." Estuaries 22:702-716. 